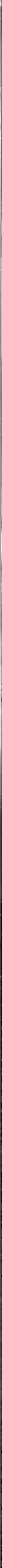


This is the official report of the Joint Services Expedition which explored Brabant Island between 8 January 1984 and 16 March 1985. The report was completed within two months of the return of the Second Summer Party to Britain, in order to serve as a basic record of events and activities. It does not attempt to cover the scientific results, only the fieldwork itself. Follow up reports will cover particular results, and complete sets of all subsequent papers and reports will be lodged with the Royal Geographical Society and the Scott Polar Research Institute libraries.

The expedition succeeded in exploring most of the island, overland or by boat, although a few small areas remain unvisited. Amongst many and varied achievements I believe that our most important one was proof that overwintering in tents in Antarctica is practical. This should open the way for other small, mobile and inexpensive expeditions visiting the Antarctic, and wishing to remain there for longer than one brief summer season.

For convenience of description, some unofficial place names used by the expedition have been used in this report. These are shown in inverted commas on maps and in the text. These unofficial names should not be quoted in subsequent literature.

Al1 35 team members who took part in the 3-phase expedition join me in thanking everyone who helped to make it possible. following:

This report is dedicated to all ihose who helped us, and to the

1. Lieutenant Gary Lewis Royal Navy, who worked for over a year as Equipment Officer of the Second Summer Team. He then suffered the bitter disappointment of returning injured to Britain from Port Stanley, their last port of call on the journey south.

2. Staff Sergeant Graham Greenway, who had played a major part in our preparations for nearly two years. He then fractured his 1 eg after less than a month on Brabant Island.

3. Our families, wives and sweethearts, who allowed us out to play, and then spent months at home waiting for news.

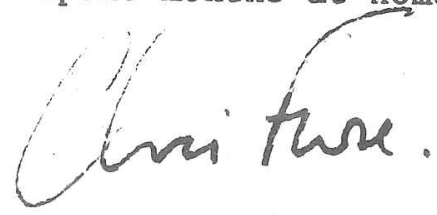

Commander Chris Furse, Royal Navy Hegg Hil1, Smarden, near Ashford, Kent, TN27 8NX. England. 
Foreword (Furse).....
Contents (thls page):

Conternts
Teaml ist.
Location.

History (Furse).

Organ isat ton Milestones.

Team Selection (Furse).

Outward Journeys and Frel ghting.................................
Narrative. First Summer (Hankinson and Furse)

Winter (Furse)
Second Summer (Waghorn and Tay lor).

Return Journeys and Free lightingo
Sumnary of Achievements
Fourse).

Foll low-up Work (Furse).............

APPENDIX ONE. SCIENCES.

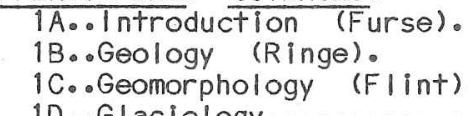

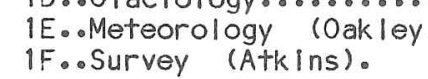

1F. Survey (Atkins).
10.0 Hydrographyo.

H. o Parasites of Seals, Birds and Fish (Kimbrey and Spottiswood).

1J.oFish \& Marine Biology (Kimbrey and Clements).

KK.:Terrestrial Invertebrates (Morris, Beattle and Martin)...
K.oBotany (Hank Inson, Stuttard and Moffat).

1Mo.seals \& Whales (Worrall, de Ger lache, and Clements).

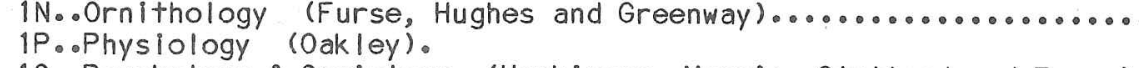

APPENDIX TWO. ASPECTS OF THE EXPEDITION.

. Medical (Morris Oakley and Mansten and Al len)....

2C.0.Camp ing (Atkins).

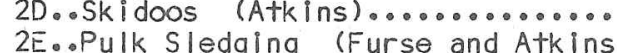

2F.o.Mountal neer In (Atkins, Beattle, Kimbrey, Taylor and Clements).

26.0. Power Boats (Worrall and Hughes).........

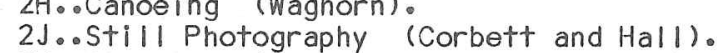

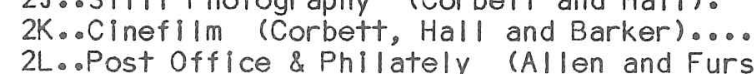

APPENDIX THREE。 EQUIPMENT。

3A..Introduction to Equipment Appendices (Furse)..........................993

3B. Packing \& Return

3D.oHuts (Furse).

3E. oRations: Assessments of Quantity \& Quality

3F. General Stores: Assessments of Quantity \& Quality.

APPENDIX FOUR. ADMINISTRATION AND SUPPORT.

4A. . Notes on Administration \& Support (Furse).....

4B. F Inance. A (Furse and Oakley).
$4 C_{0}$. Publicity (F)

4E.. The Falkland Islands (Furse).

$4 \mathrm{~F} .0$ British Antarctic Survey (Furse).

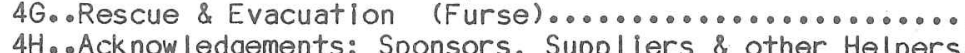

MAPS。

Antarctic Peninsula.
Palmer Archipelago.
First Summer Party.

First Summer Party.

Winter Party. March to August...........

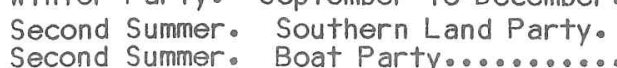

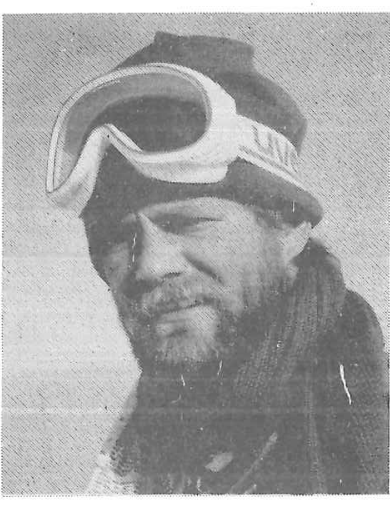

ATKINS

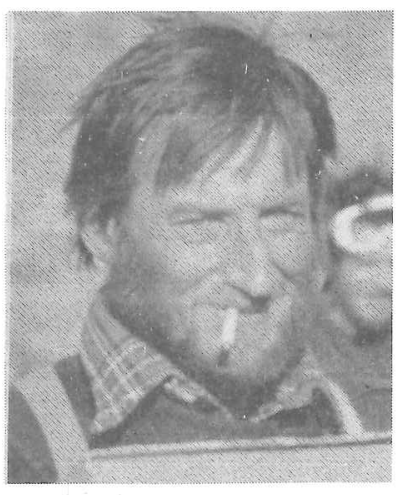

FURSE

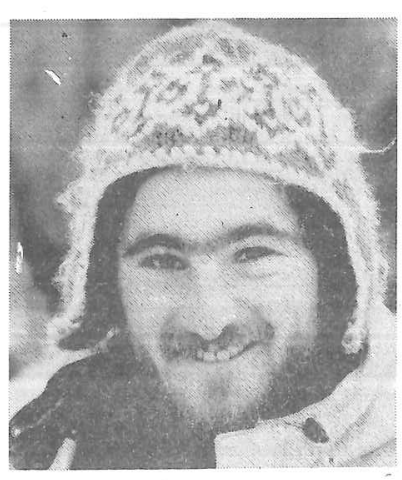

HILL

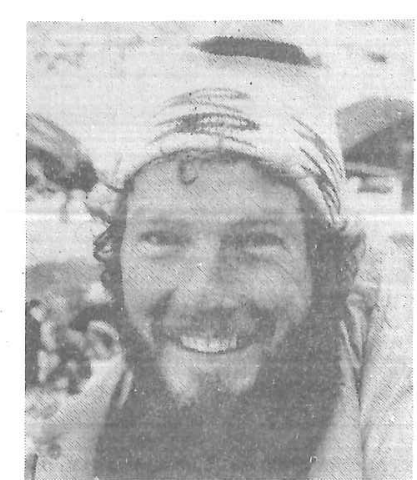

MORRIS

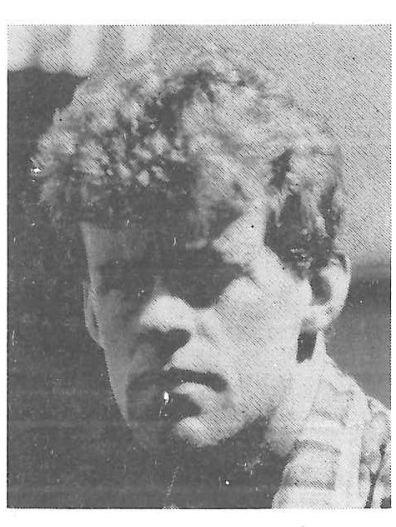

CORBETT

\section{FIRST SUMMER}

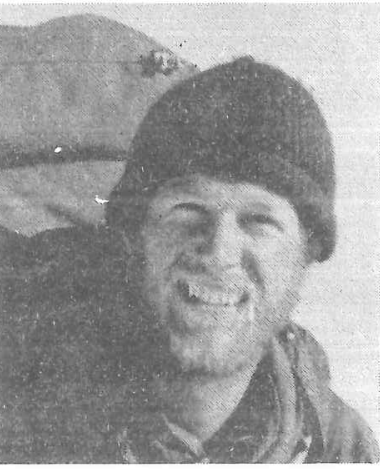

TRATHEN

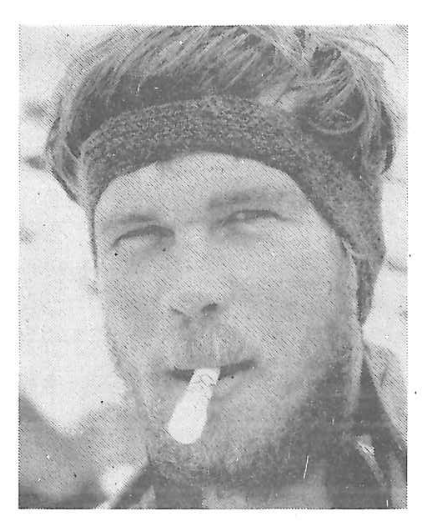

DE SILVA

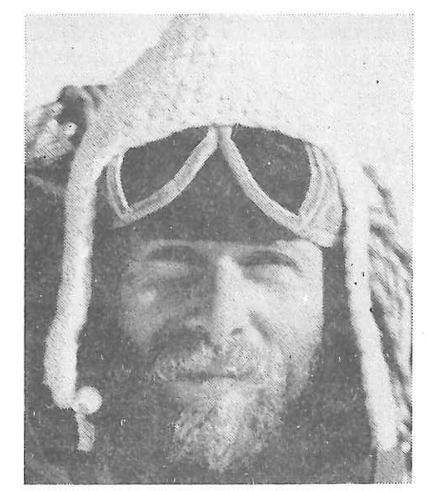

HANKINSON

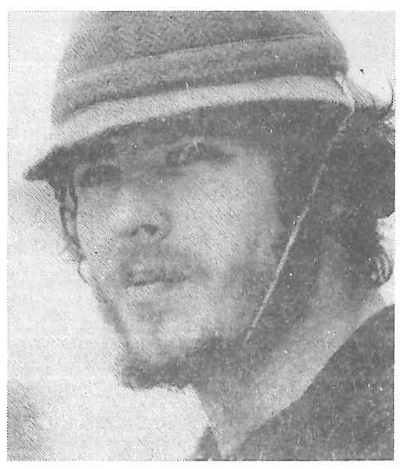

MCLEOD

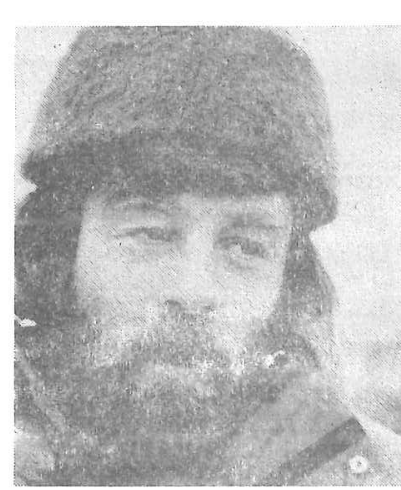

WORRALL 


\section{SECOND SUMMER LAND PARTY}

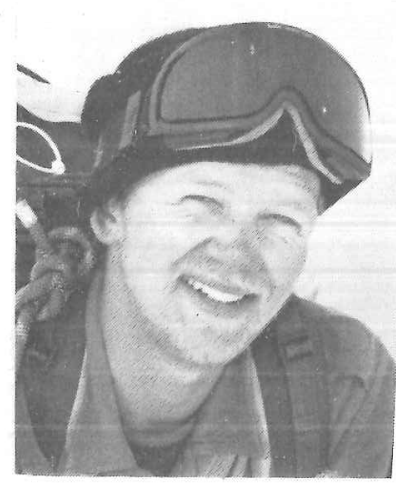

ALLEN

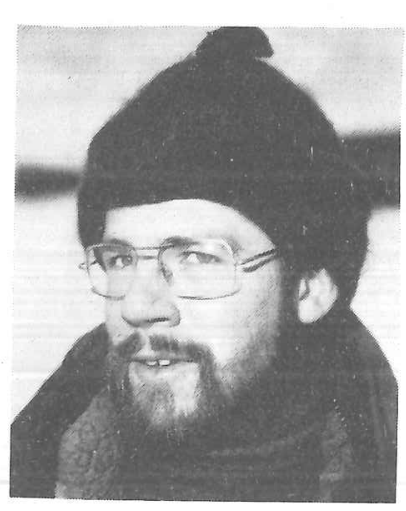

FLINT

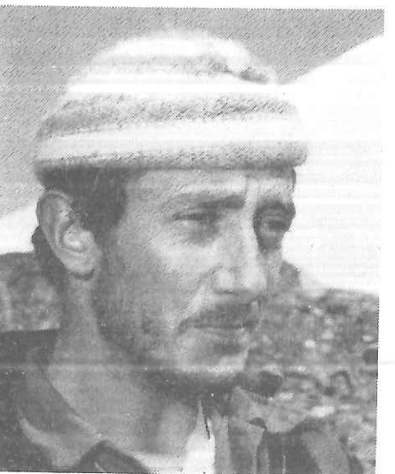

MARTIN

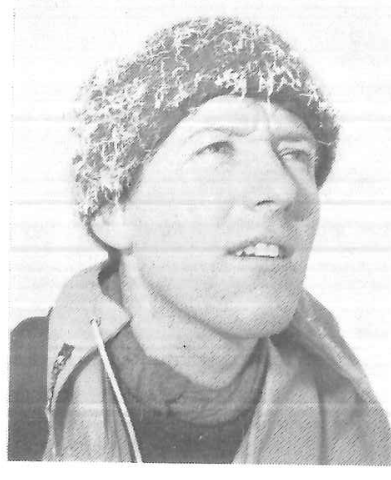

BALL

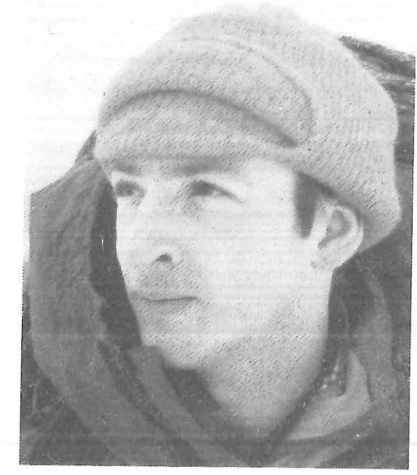

GREENWAY

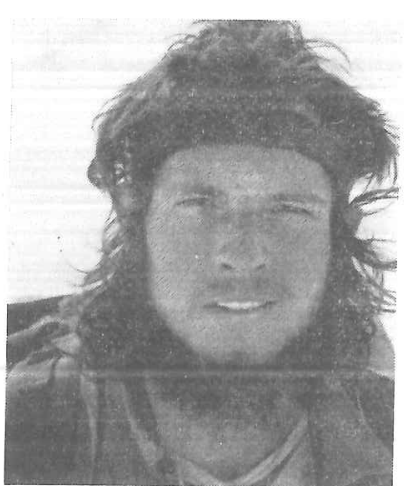

RINGE

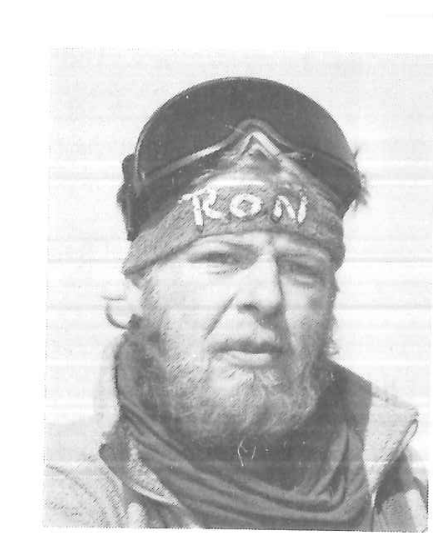

BARKER

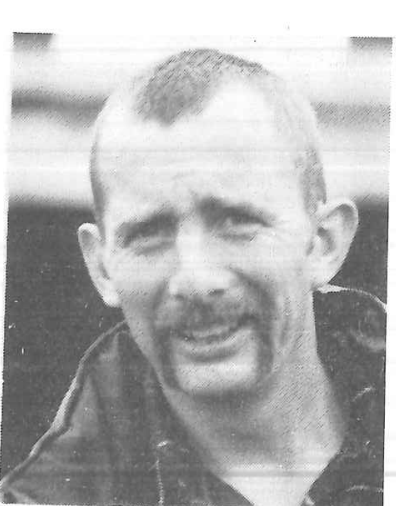

LAWRENCE

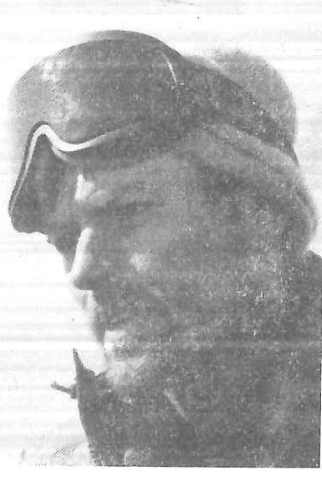

TAYLOR
TEAMLIST: FIRST SUMMER and WINTER PARTIES. His Royal Highness The Prince of Wales.

His Royal Highness The Prince of Walc
Overali Expedition Leader:
Commander Chris Furse RN.
Director of Naval PT and Sport:
Lt.Cdr. Clive Waghorn RN and Fit

FIRST SUMMER PARTY. 10 MEN. (January 1984 to March 1984, plus travel). Commander CHRIS FURSE RN. (48).................................. Staff of Flag offlcer Medway.
Leader; Scientific coordinator; Ornithology. (mountaineer).

Flight Lieutenant BILL HANKINSON RAF。 (31) ..................
Deputy leader; Botany; Metoorology. (mountaineer).

$\therefore$ RAF College, Cranwell. Corporal TED ATKINS RAF. (25).

maintenance. (mountaineer).

Leading Airman (Photographer) JED CORBETT RN. (24)...

.RAF Guters Ioh.

Still photography; Cine photography. (coxswain)

Corporal JEFF HILL RM。 (27)
Radlo; FISh; Stores.

Mar Ine MAC MCLEOD RM. (23) .........................................

Feet Photographic Unit.

E: in

E:- 3

E:

E: $=$

Ei⿱i⿻日木-

ㄷ.:므

E.iiin

Fi:

E!

E.

in

Sin

Sin

Sin

sivi=

E IIII

E-

$E=$

$E=$

E

$E=$

$\Sigma=$

$E=$

Doctor JONATHAN MORRIS, civilian. (25).....
Doctor; Terrestrial invertebrates.

Ge Corporal KEVIN de SILVA RE. (24)............

Lleutenant SIMON TRATHEN RM。(25)

Geology; Geomorphology. (mountaineer).

Corporal DICK WORRALL RM. (31)....................................
Boats; Seals \& Whales. (mountaineer; coxswain).

WINTER PARTY. 12 MEN. (March 1984 to December 1984, plus travel).

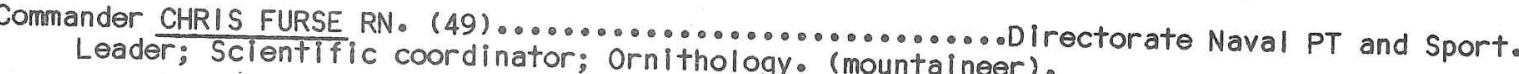

Surgeon Lleutenant HOWARD OAKLEY RN. (30)...................
Deputy leader; Phys Plology; Doctor; Meteorology.

Corporal TED ATKINS RAF。 (25)................................Personnel Management Centre RAF. (corpora

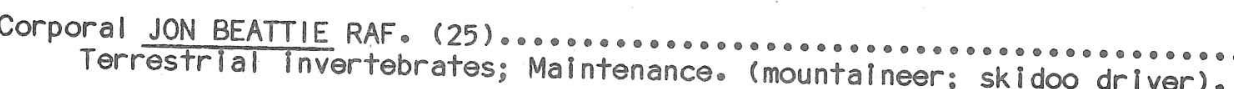
Still photography; CIne photography.
Shy Airman (Photographe JED CORBET

... Fleet Photographic Unit. Captain NICK EVANS PWO Yorkshire Regiment。 (32)... Monsleur FRANCOIS de GERLACHE, civiliano (23)
Seals \& Whales; Tent repairso (skler)

Army Staff College, Camberley.

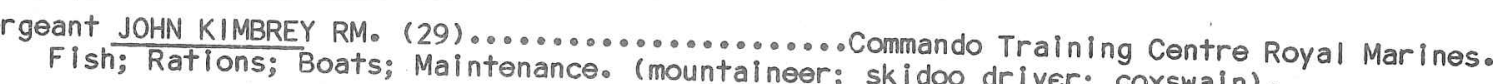
(mountaineer; skidoo driver; coxswaín).

Corporal JIM LUMSDEN QLR. (26).............................. ist. Queens Lancashire Regiment.
RadIo; ASSIStant meteorology; Camp stores. (skidoo driver). Mister MIKE RINGE, civilian. (23)...
Geology. (skidoo driver).

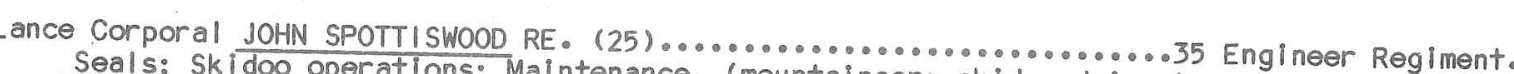
Sergeant PETER STUTTARD REME. (29)

geant PETER STUTTARD REME. (29) ..................................3 Flight Army Air corps.
Botany; PSYchology; Electrical maintenance. (mountaineer; skidoo driver). 
TEAMLIST: SECOND SUMMER PARTY. 17 MEN. (December 1984 to March 1985, plus travel).

Patron: His Royal Highness The Prince of Wales. Overall Expedition Leader: Commander Chr is Furse RN.
Second Summer Party Leader: Lleutenant Commander Clive Waghorn RN. Second Summer Party Leader: Lleutenant Commander Clive Waghorn
Rearl Ink:
Director of Naval PT and Sport.
FIt.Lt. BIII Hankinson RAF.

\section{BOAT PARTY. 7 MEN.}

Lieutenant Commander CLIVE WAGHORN RN. (37).................Britannia R.N. College, Dartmouth. Teader; Canoelng; Assistant ornithologye (mountaineer; canoeist)

Lieutenant RICHARD CLEMENTS Royal Angl I ans (25).........................Royal Anglian Regiment.

Lance Corporal KERRY GILL Royal
Radio. (canoeist; skier). Leading Airman (Photographer) TIM HALL RN. (27)................................... HMS Daedalus
Stlll photography; Cine photography; Mechanical maintenance. (mountaineer; coxswain). Lance Bombardier MARTIN HUGHES ROYal Artillery. (29)......................klel Training Centre.

Lieutenant GARY LEWIS RN. (27).
Ornithology; Equipment.

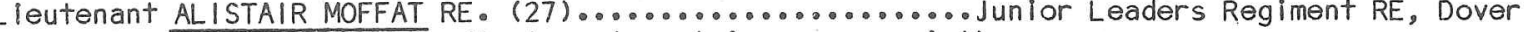

Captain TONY WILLIAMS RAMC. (25).
Doctor; Geology. (canoeist).

. Royal Army Medical College.

SOUTHERN PARTY. 10 MEN.

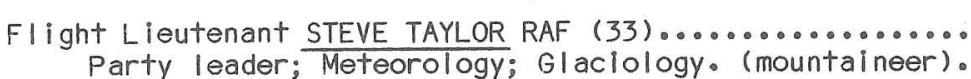

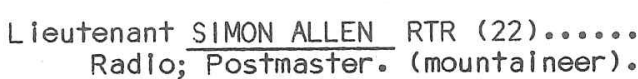

Flight Lieutenant Dave Ball RAF (33)..............
Stores; General Maintenance; Psychology.

Leading Airman (Photographer) RONNIE BARKER RN。 (24) ......................... HMS. Osprey Cine photography; still photography; Electrical maintenance.

Lieutenant PAUL FLINT RN. (27) ........

HMS.Cochrane.

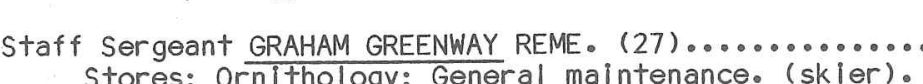

.S.E.M.E.,Bordon。 geant WILLIE LAWRENCE RE。(31) ........

General assistante (mountaineer).

Captain STUART MARTIN RAMC. (32)................................. Royal Army Medical College. Deputy Party Leader; Terrestrial invertebrates; Doctor; Botanyo (mountaineer)

Mister MIKE RINGE, civilian.

\section{WINTER}

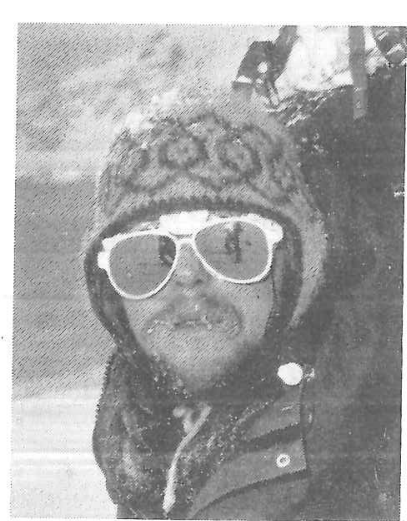

BEATTIE

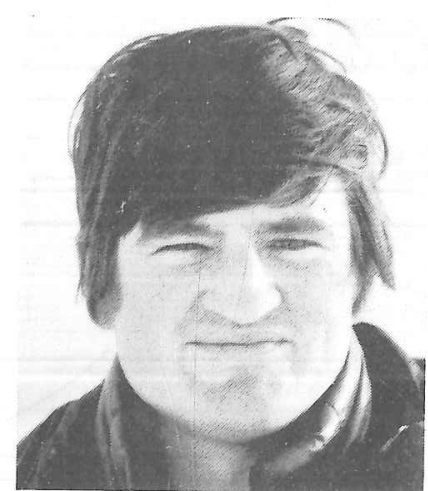

EVANS

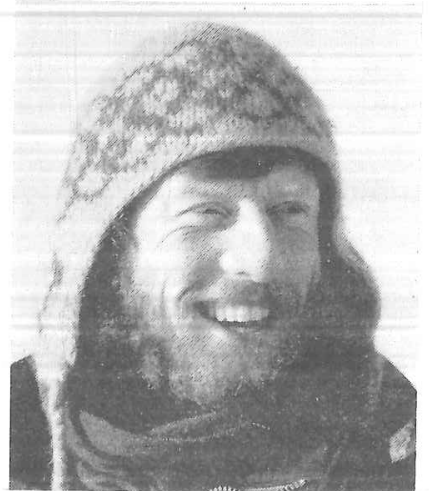

KIMBREY

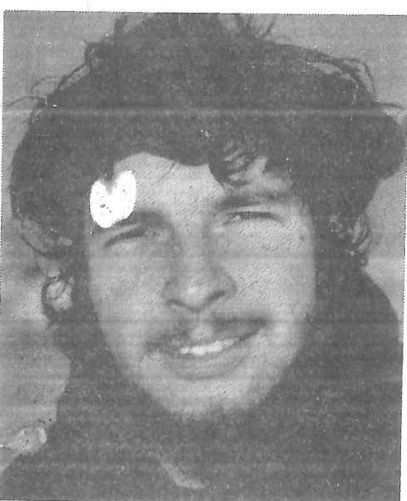

RINGE

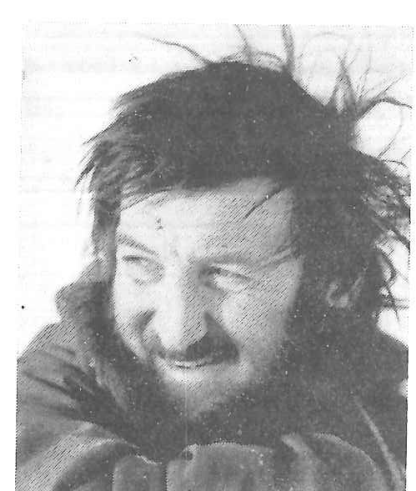

FURSE

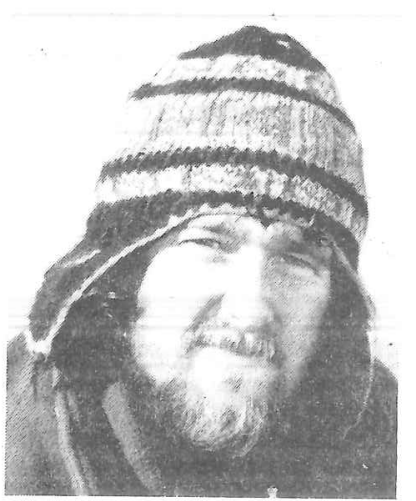

LUMSDEN

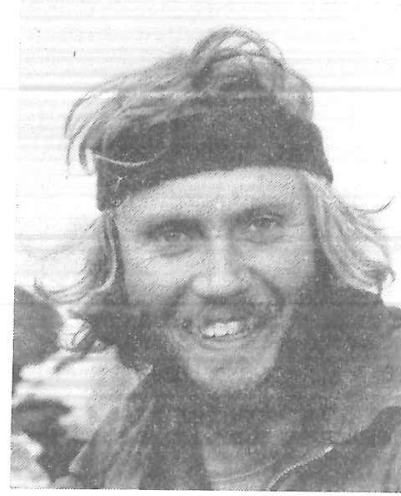

SPOTTISWOOD

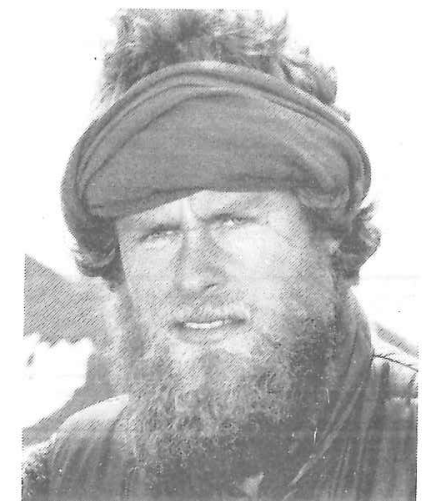

CORBETT

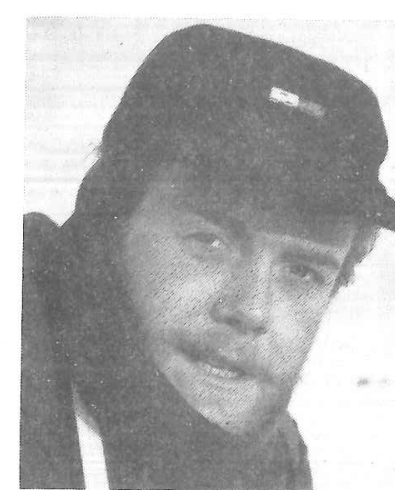

DE GERLACHE

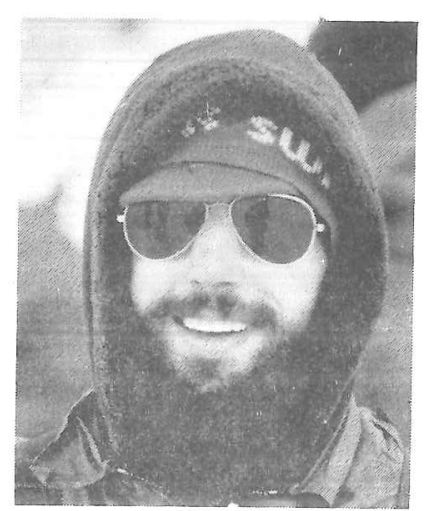

OAKLEY

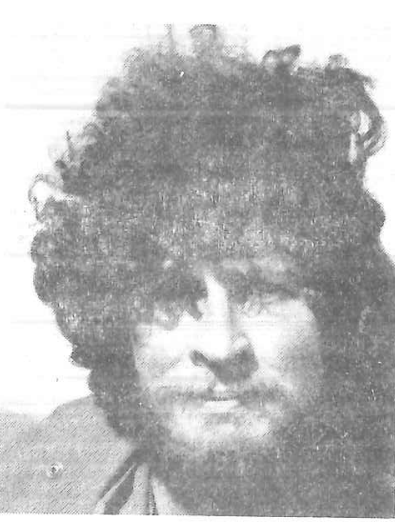

STUTTARD 


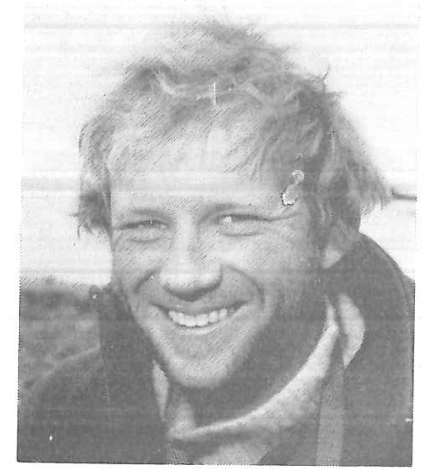

CLEMENTS

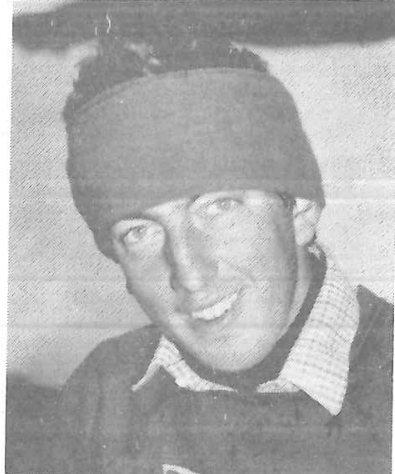

GILL

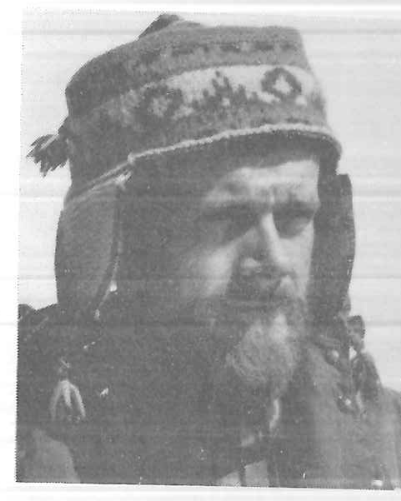

HALL

\section{SECOND SUMMER BOAT PARTY}

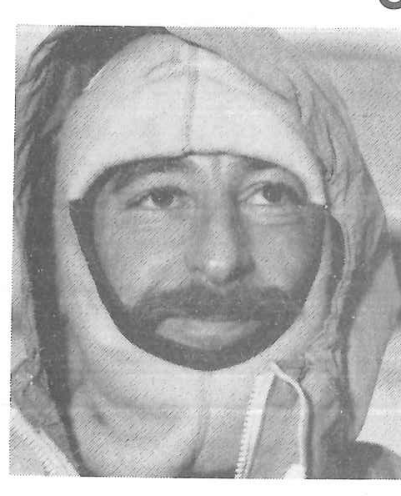

HUGHES

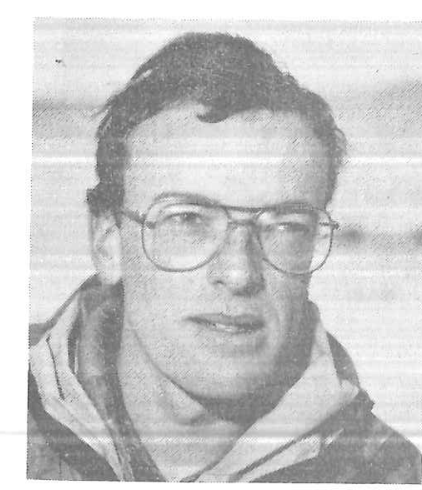

MOFFAT

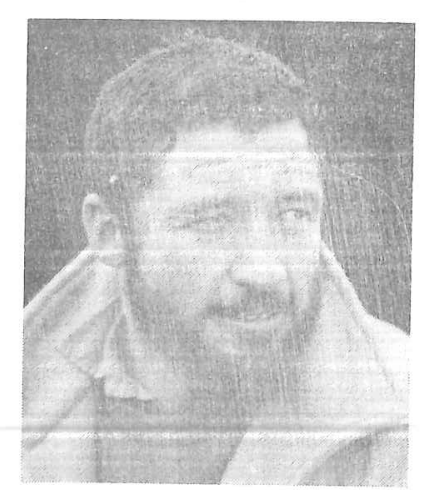

WAGHORN

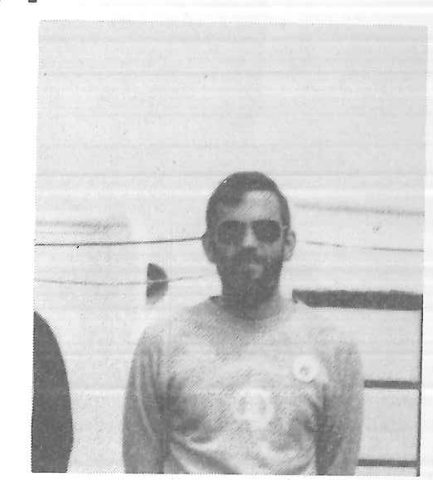

LEWIS

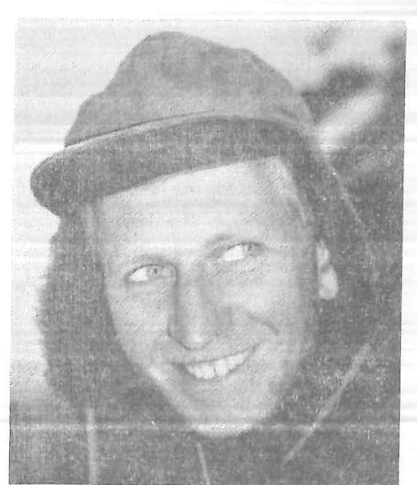

WILLIAMS

at $64 \mathrm{~S}$, within the Antarctic off the west coast of the Antarctic Peninsula wide, it is part of the Palic treaty area. About forty miles long and 15 several much smaller islands. The 10-30 the archipelago from the Peninsula Bay lies between Brabant and Anvers Island north the island is exposed to the it is possible to see smith ts on clear days Deception Island 98 miles northeast in (

Antarctic in climate and of the Antarctic Circle, the archipelago is wholly over 300 miles north to the Antar. Cold Antarctic surface water stretches with the limit of packice in winter. and summer. The climate is marit. from the west, then tending to be with successive depressions arriving Peninsula. Mean monthly temperatur and $+1 C$, with minimum down to $-40 \mathrm{C}$ were expected to range between $-10 \mathrm{C}$ Antarctica, precipitation is very Force are frequent, and may arise calm spells and more sunshine than further South Shetlands.

Brabant Island itself is very mountainous. The north and south reaching about 8500 ft at Mount Pas The main ridge runs western seacliffs, with gentler, more at Mount Parry above precipitous Lower but equally dramatic mountains extens north, this main ridge. Deep bays cut into the few drowned peaks form offshore islands.

coastal points, a few is deeply covered with snow and ice, apart from small (hlaciers.

Seals, penguins and other birds, minute terrestrial invertebrates, and some sparse vegetation are almost entirely confined to the snowfre
coastal areas.

During the brief Sumer, from November to March, planes sometimes overfly en route to and from the bases further south, and an occasional ship passes offshore. However in Winter the isolation is an occasional ship outside contact then is by radio, with the nearest British Antarctic Survey bases at Faraday ( 87 miles south) and Signy Island (552 Antarctic Survey and with Palmer Station, the American base 66 miles south miles north east),

$$
\text { (sland. }
$$

had ever landed on have sighted Brabant Island in passing, but hardly any difficult even to find photographs of the island. The small and scat was snowfree areas had prevented economical 1sland. The small and scattered although the geology in particular was of great interion by BAS scientists,

like this, Altogether Brabant Island was an ideal target for an expedition mobile parties of mountaineers with scientific exploration accomplished by unexplored islands in the rorld, and one of thas of the largest 
The scanty history of Brabant I sland is hard to find, beyond the brief summary in the
Antarctic PIlot. research which provided most of the information below.

On 19 February 1819 the South Shetlands were sighted for the first time, from the storm-driven brig Will fams. Her Captain, Will lam Smith, returned to land there in October
1819. In January 1820 Edward Bransfleld RN, appointed Master of the Willilams, surveyed the strait that now bears his name, and while doing so sighted Trinity Is land sealers working Nathaniel B Palmer, Captain of the sealer Hero, (who may have sighted the Peninsula, but probably never sighted Brabant Island), was surprised in February 1821 to meet the ships of

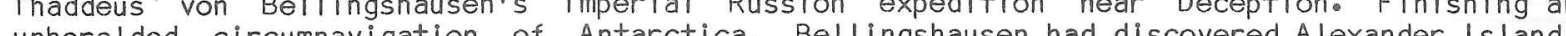
then sailed north in a bllzzard past unseen Brabant Islando In February 1821 John Davis, Captain of the sealing brig Cecilia, found more sealers than seals in the South Shetlands: from Low Island he sailed SE reaching 645 near the Peninsula, and quite probably sighting (northeast of Brabant Island) around Hoseason and Intercurrence Is I lands, and possibly as far as Two Hummock Islando It is likely that Hoseason and other sealers sighted Brabant Island in that decade, and some may even have landed there, but they were all secretive, and few stripped the beaches: in 1829 Webster reported finding not a single seal in the south Shetlandso In February 1829 Henry Foster, in command of HM Sloop Chanticleer, landed on Hydrogran Brothers, ofl merchants of London, sponsored further explorations: in 1832 John Biscoe in the brig Tula with the cutter Lively, landed on the west coast of Anvers Island, naming the area

About 1840 three major national expeditions (d'Urville of France, Wi ikes of the
United States and James Clarke Ross of Britain) all spent some time near the South Shetlands, as well as reaching the far coasts of Antarctica. However none of them came so close to Brabant I sland as had Bellingshausen.

American sealers later again visited the islands off the Antarctic Peninsula, sporadically and region before 1873, and fifteen in the following twenty years, but with no detalls of where they went. Robert Headland of the Scott Polar Research Institute is bringin period, Brabant \& Anvers I I lands became known as "Palmer Land".

In 1873 the steam whaler Gronnland, Captain Edouard Dal I man, sai led from Hamburg to reached the South Shetlands, meeting a little fleet of sealing schooners from Stonington Connecticuto. There were very few seals. He went as far as the south end of Anvers Island. the Peninsula, or breaking right through the Peninsula: he named it Bismark Strait. During this voyage Dal man also discovered the bay which now bears his name, but understandably bel ieved that Brabant and Anvers sland were jol ned parts of " nPalmer Land". He approached Cape though the charts were inaccurate. He saw many Humpback and "Sulpher-bottomed" (B|ue) Whales, at that time still virtually immune from the whalers.

Whalers may have visited the area in the 1890 s, when steam power and Svend Foyn's
invention of the harpoon gun at last allowed them to hunt the fast and powerful rorquals, so plentiful near the ice. Adrien de Gerlache, a young Lieutenant in the Belgian Navy, personally initiated,
organised and led the Expedition which L inaugerated the "Herolc Age" of Antarctic exploration, in the Norwegian sealer Patria, which he bought, refitted, and renamed the Belgica. One of
his several aims was to discover the strait which was then supposed to lead east from Hughes Bay right through the Antarctic Peninsula in the latitude of Hoseason Island. He proved that no such strait existed, and instead he was led southwards into the Gerlache Strait.
On 30 January, 1898 , Lt de Gerlache and Lt Danco (Belgian). Roald Amundsen (Norweglan), On 30 January, 1898, Lt de Gerlache and
Dr Frederick Cook (American) and Henryck Arctowski (Polish) made the first recorded landing on Brabant Island at Cape d'Ursel on the south shore of Buls Bay, with two small Nansen sledges, snowshoes, one tent, one stove and 10 meters of silk rope. They spent five days and nights on
the pledmont, protecting their tent with snowwalls, and reaching about $1700 \mathrm{ft}$, but unable to get up the icefalls above. This short stay was notable for several reasons.
Amundsen's first stay ashore in Antarctica, it was the first time on record that anyone had used tents in Antarctica, or sledges. The expedition then discovered the Schollaert strait separating Brabant from Anvers Island, before salling south through the Gerlache Strait into winter in Antarctica. Many of the names around the Gerlache Strait derlve from the Belgica expedition, including Brabant itself, Lecolnte Island, Buls Bay, the Solvay Mountains and the Danco Coast. (Gaston de Gerlache, son of Adrien, led the 1957 Belgian National Expedition to links with the Belgica expedition as we wintered in tents \& hauled pulk sledges with Francoiss.

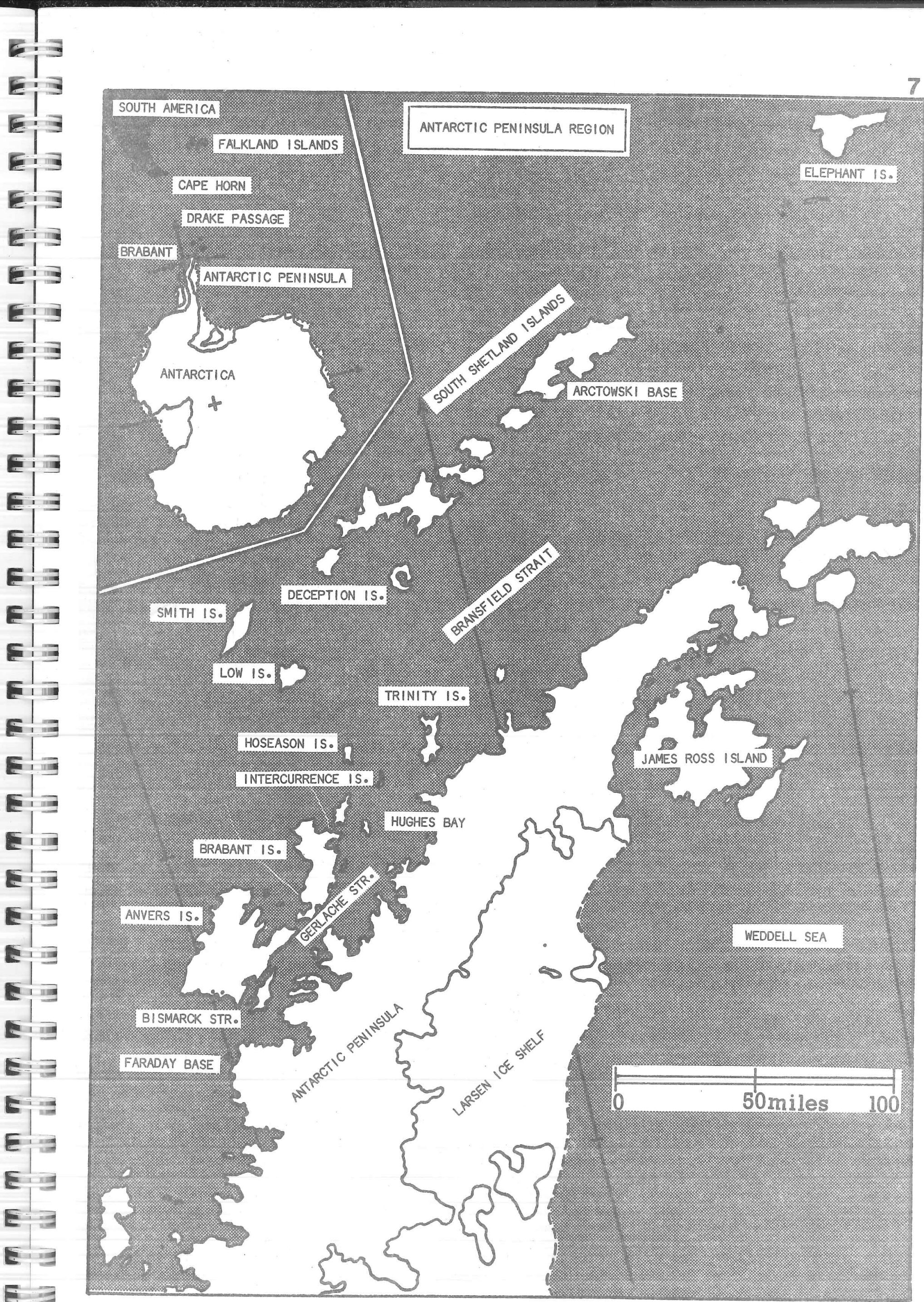




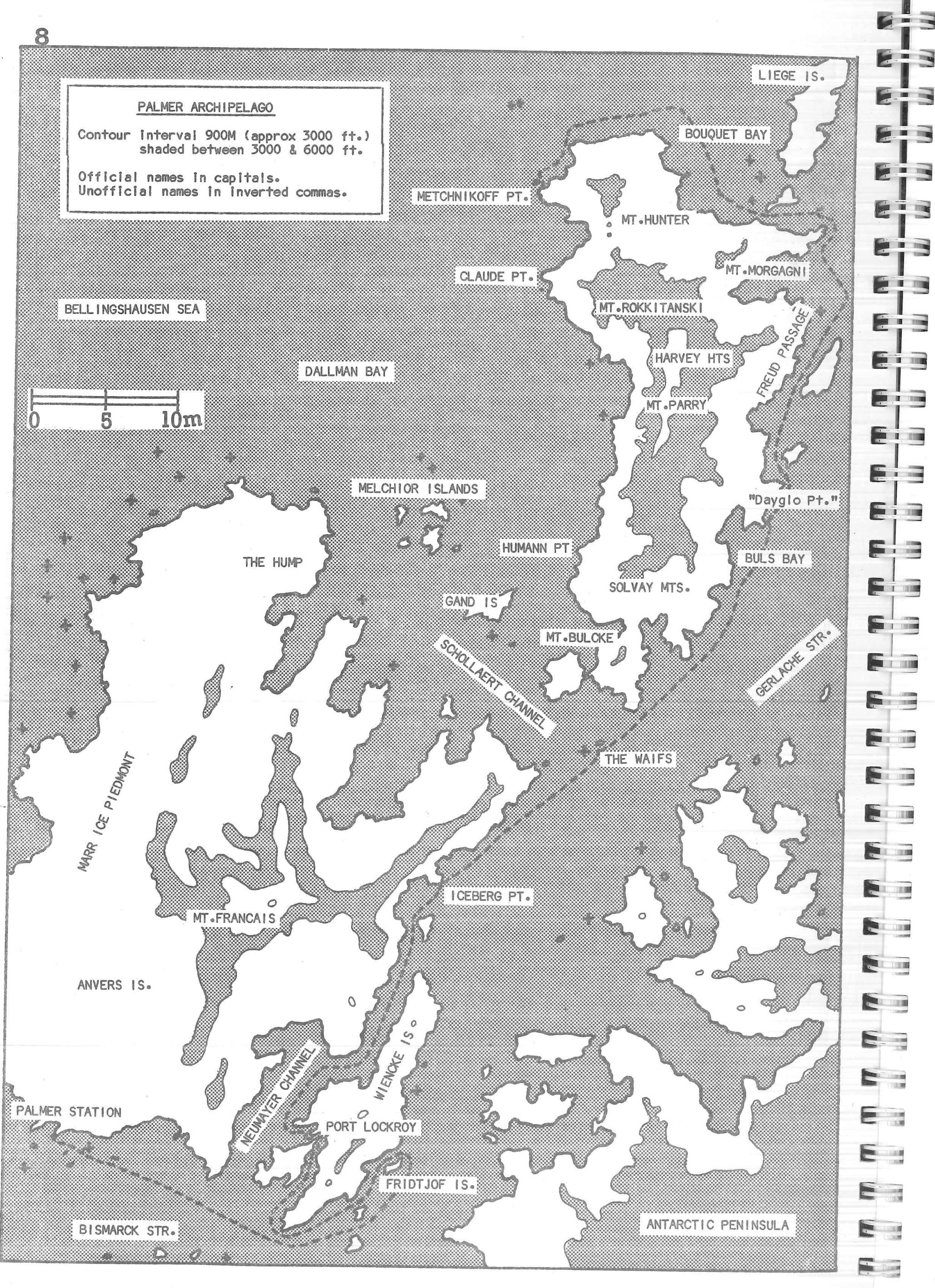

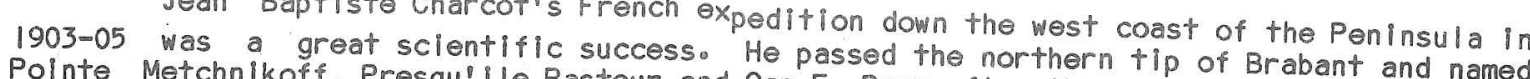
(who were probably family friends) and also Claude PoInt and Astrolabe Needle (the latter
affer d'urvilles vessel).

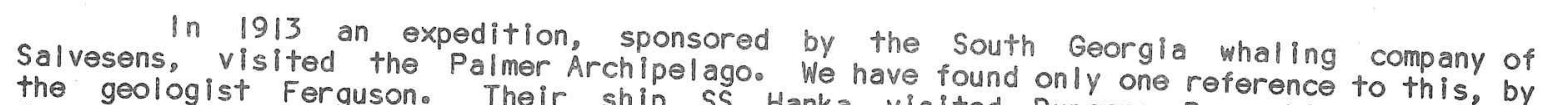

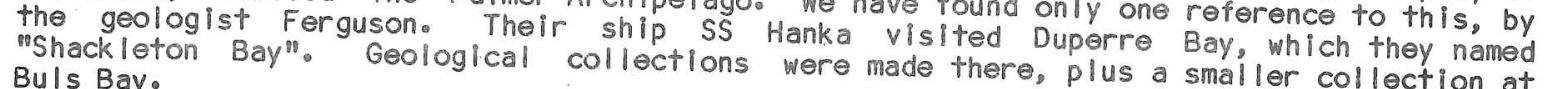
Buls Bayo

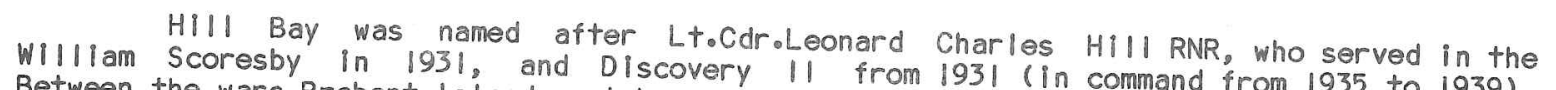

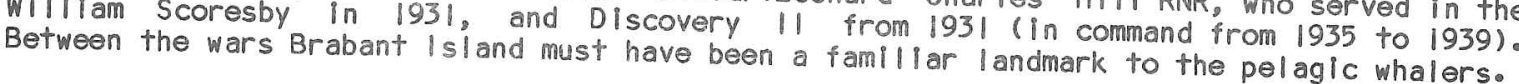
further The unsung Britlsh Grahaml and Expedition of 1934-37 under John Rymill, landed Peninsula, finally disproving the Argentine Islands, and surveyed a vast stretch of the

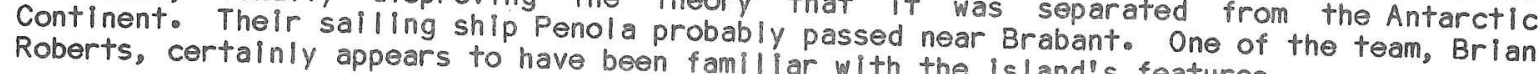

nations From 1943 there was increasing sclentific activity in the reglon, with several Peninsulao. The nearest basehuts to Brabant were the Britlish base at Portal Pol the 1980. Although ships passed the sts lond in the Melchh or Istands, both abandonned before

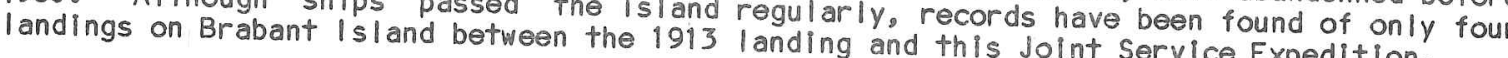
Hydrograph In $1951 / 52$ parts of the east coast wore surveyed by Cdr.Hunt RN in charge of an RN out by ken Blalk lock in Aprill 1955, in the Norsel, chartered by FIDS. However they do not
appear to have landed.

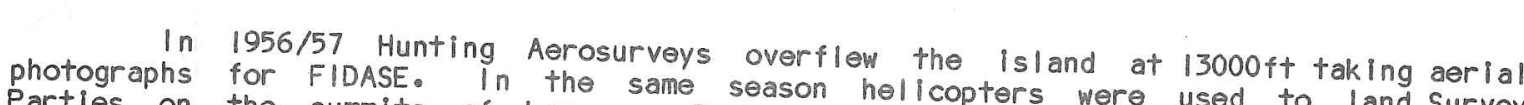

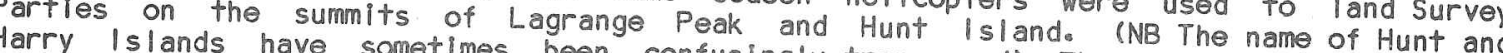

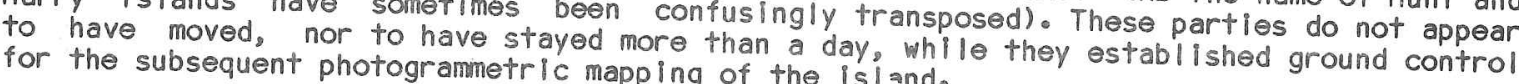

Roberts When the subsequent Dos map of the area was being produced in 1959, Brian

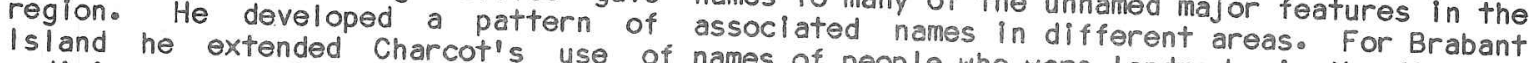

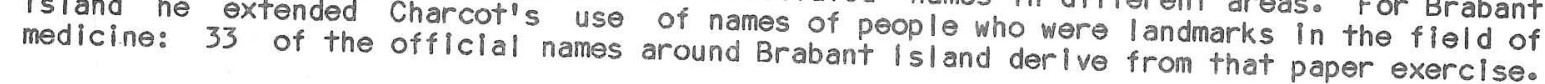
In 1964 a FIDS geologist Roger Bally landed br lefly by boat somewhere on
Brabant Island. However Dr Adio at BAS was unable to find any record of his findings.

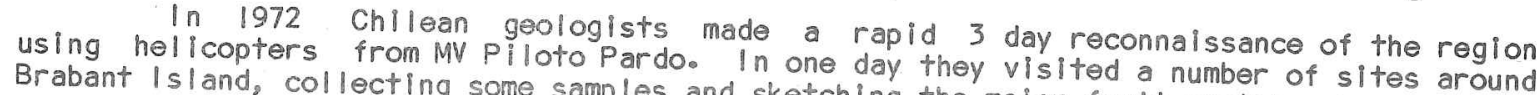
che

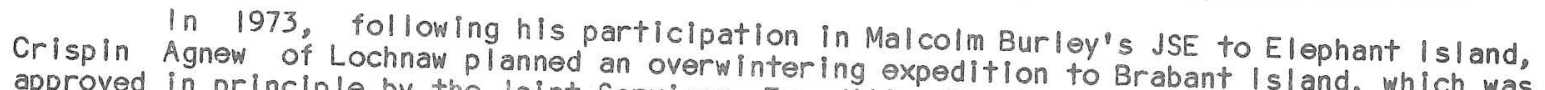

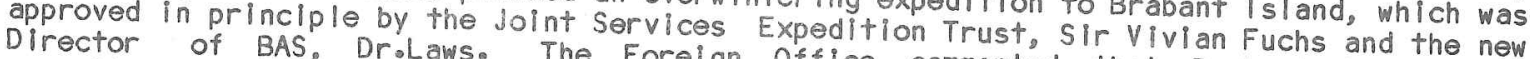
exceptionaliy Inhositiables even by Antarctic standards, and advised consideration of
other possible areas. That

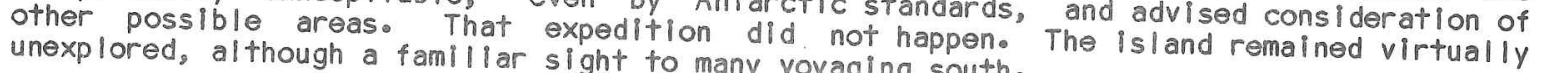

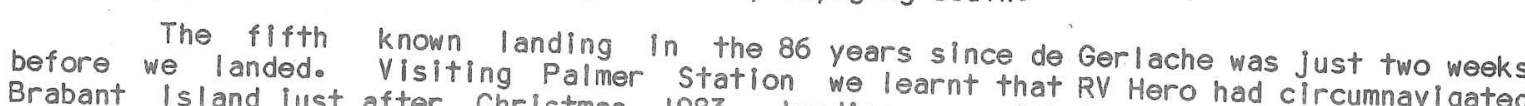
to census the breeding birds, This vis 1983, landing an ornithologist by boat at two sites

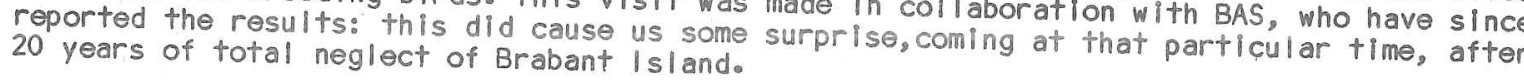

ribs at Me found no rellics of sealers or whalerso cone whale's Jawbone and a few small

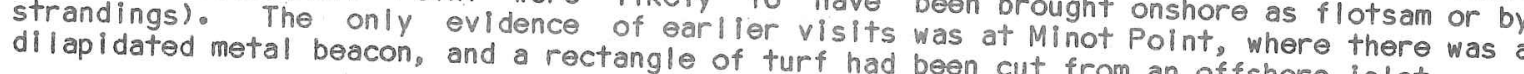

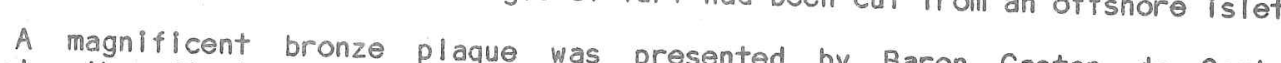
commemorate the first bronze plaque was presented by Baron Gaston de Gerlache to
their landing bite his father in 1898 . We had planned to Install thls south over Harvey Heights. So, while Francols was on the is and was prohibitive for sledging across the Bellifasecamp at Metchnikoff Polint, looking south to Anvers Island a praque in 

Fund Ralsing and scientific arrangements, The purposes of including this dull but vital
work in this report are: firstly to provide a factual record, and secondly to give prospective expedition leaders an indication of the work load they must be ready to take
on. Hopefully this will not put them off? The expedition was not concelved by any club, or cormittee or authority, it was just
dreamed up by Furse. So the overall programme strategy was matched to his career from the
first. For two years, while serving in the 8 th Frigate squadron in $1980-82$ minimal effort was expended, merely laying the foundations. The real hard work was ail put off
until after mid-1982, when the selected team became aval lable to share the workload. The

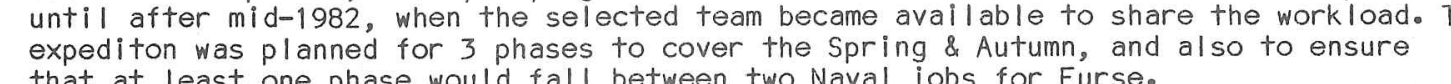
that at least one phase would fall between two Naval jobs for Furse.
in practice a few ripples did disturb the smooth flow of this strategy - but they

1980 June...... Informal discussions with Captain Barker of HMS Endurance.
1980 August.... Initial out line proposal (for 16 month expedition to James Ross I sland) sent
to BAS, \& copled to FCO. RGS, Hydrographer, HMS Endurance, DNPS \& DNOA(E) to BAS, \& copled to FCO, RGS, Hydrographer, HMS Endurance, DNPTS \& DNOACE)
1980 November.omeeting Furse/D irector of BAS. DecI ded on Brabant I sland.

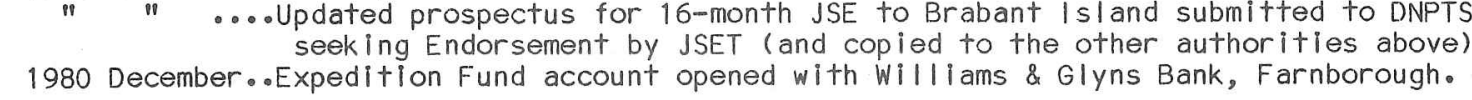

1981 January... JSET endorsed the expedition in principle, with reservations about wintering.
1981 February. oHMS Endurance photo reconnaissance of Brabant I sland (completed March). 1981 February. HMS Endurance photo reconnaissance of Brabant Istand 1 comp leted 1981 March .... Photographs of Brabant I sland taken by Burk itt from RV Hero.

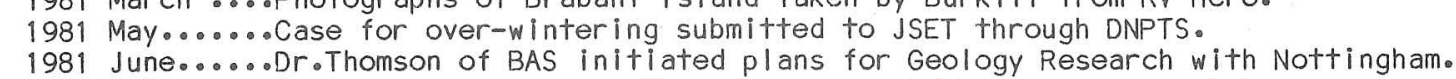

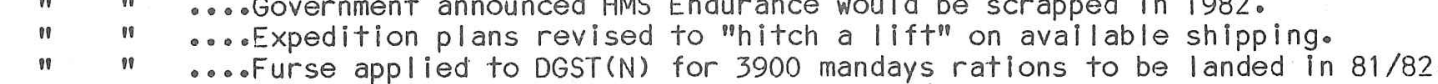

1981 July......DEST(N) \& NP 8901 agreed to provide rations \& kerosene respectively.

" ....HMS Endurance agreed to land rations \& kerosene in March 1982.

" " $\quad \ldots$ A...Approached Lindblad Travel Inco, IUSARP \& USCG seeking transport for team.

" " $\quad$ ".... CanseT formally Endorsed the First Surnmer phase. They would be prepared to SET formally Endorsed the First Surmer phase, They would be prepared to
consider the Second Summer later. However the Director of SPRI had advised that wintering in tents was too dangerous and the JSET recorded

"... a "final \& irrevocable" decision not to support the Winter Phase

1981 August...... Before salling for the West Indies, Furse sought support for wintering in

tents from Surgeon Captain Dalgl iesh \& Doctor Stonehouse.
1981 September.Captain Dalgl lesh discussed Wintering with DGNPS (the Naval member of JSET). DGNPS would be prepared to reconsider, if MDG(N) could state that the Physiological research was valuable, and that a Doctor would be aval
Dalgliesh discussed physiology with Vice Admiral Harrison, MDG(N).

"....Canvassed for Equipment Officer through AMA, RNRMMC \& RAFMA.

" " $\quad$ "...Formal request to MDG(N) for a Medical Officer.

" "

consider team transport, If plans were supported by the Director of
1981 November.osir Rex Hunt, Governor of the Falklands \& HIgh Commissioner of BAT,

" "... $\quad$ Ratlons packed at RNV Botley.Furse family weekend marking-up for 5 dumps. " "....HMS Nelson agreed to act as Accounting Unit for rations.

981 Decento.

" "...oths Ariadne in London, Furse visited MDG(N). Sir John Harrision called for

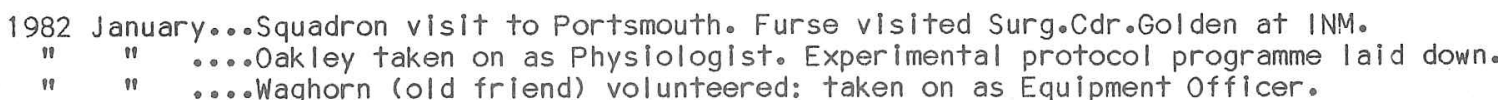

" " $\quad$....Waghorn (old friend) volunteered: taken on as Equipment officer.

1982 February. Draft Defence Council Instruction ( (seek ing is \& OW volunteers) submitted.

1982 March .... (26th) . Rations \& kerosene embarked in HMS Endurance.

Kerosene drums ruptured by heavy seas, replaced by ship's Avcat.
Rations \& fuel landed at Palmer station instead.

" " ....expedition plans changed to sledge stores from Palmer Station over across Dal Iman Bay to Brabant I sland. Supporters advised.

Ir Vivian Fuchs supported plan to winter in tents.

" "...s.started to look for Inflatable Power Boats, sledge parachutes \& Skidoos.

" " .... Furse finished job as SMEO to 8th Frigate Squadron.

1982. March.... (2nd).RGS decided to give Approval to the Expedition, (advised on 25th).

1982 Apr $11 \ldots . . .(1$ st).Defence Council Instruction published calling for is a OW volunteers.

" $"$ "...A Arranged venue for selection Intervilus at the RGS in September.

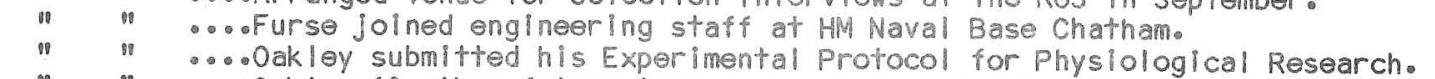

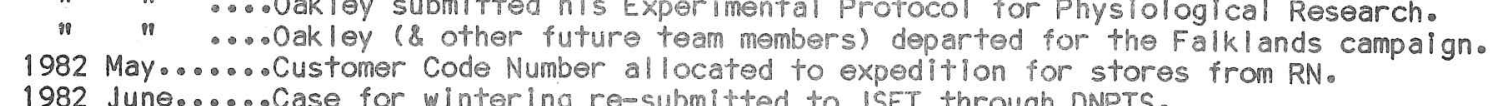

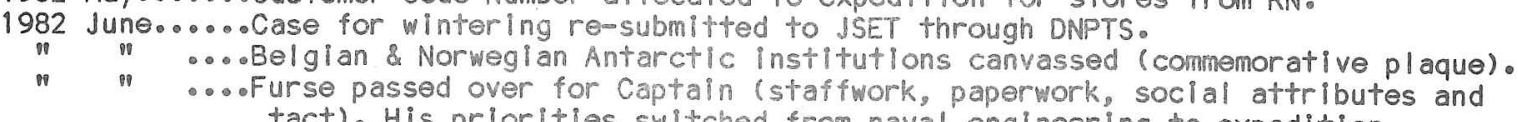

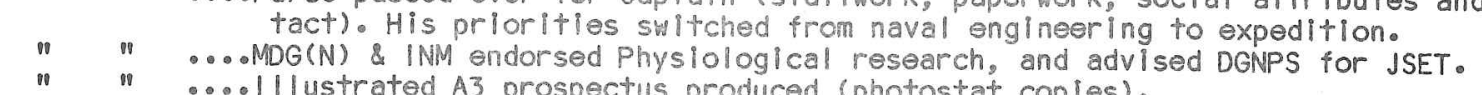
1982 July........ J SET formally Endorsed whole expedition, including the Winter phase. $"$ " $\quad$....Bernard de Gerlache met Furse, discussed plaque, \& Francols participating. 1982 August....0.0.0. Shortilist of applicants for interview drawn up. 1" ".... Canvassed for more applicants through main tri-service newspapers.

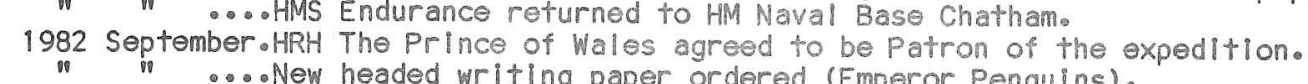

" " $\quad \ldots$ Nelp headed writing paper ordered (Emperor Penguins). " " $\quad \ldots$ DDST (N) agreed to provide two 5 meter Avon inflatable boats on loan.

" "

" " $"$ "..ovest German Wegener Institute canvassed for transport.

" "....Expedition plans outlined in letter to commanding Offitin in service. Big dayl

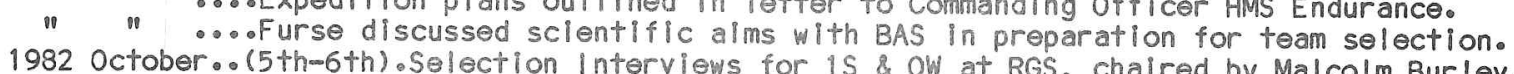

282 october..(5th-6th). Selection Interviews for is \& OW at RGS, chaired by Malcolm Burley.

" " ....Waghorn appointed BRNC Dartmouth - unable to Join First Summer.

" " ....John Spencer engaged for civilian fund-ralsinge

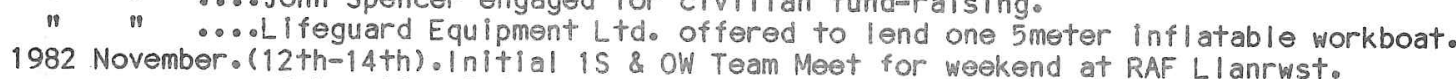

Jobs al located; organisation "treell formed; team briefelanws

" " $\quad$ "...ofirst sponsorship received (from RN \& RM Mountaineering Club).

" " $" \because .$. Professor Baker submitted applicatlon to NERC for geology research grant. " $\quad$ ".... Commando Logistic Regiment RM agreed to provide stores-packing facilities. " " $"$ "...Addback funding requested from DNPTS for skidoos \& basecamp tents.

1982 December...Contacted Defence Attache Santiago about Chilean Naval Chinook hel I copters. " " ...ofurse visited SCRDE discussed clothing trlals. Tralning

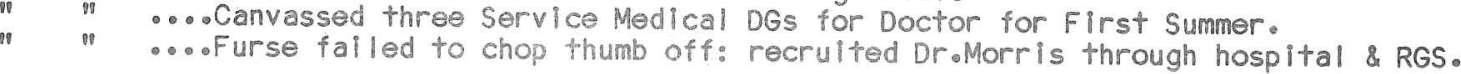

1983 January... Newsletter No. 1 sent out (29 team members + COs +41 external addressees).

" " $\quad$ "... Initial enquiry to DEST (N) for frelghting of gasoline to Falklands FCO confirmed that expedition was acceptable under the Antarctic Treaty:
but NB. 1 . Adventure "tralning" not allowed,

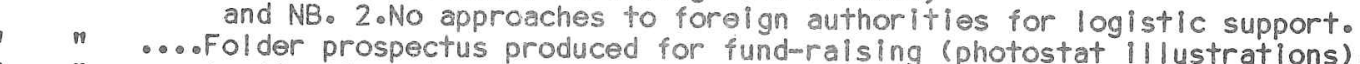

". " $\because$...Applicatlons to ReS \& Gino Watkins Memor Ial Fund stated sclentific work was

" "....BAS reported that expedition rations at Palmer were perished this wording.

" $"$ HMS Endurance requested to inspect ratlons at forthcoming visit to Palmer.

1983 February.DOSTCN
"

" " $"$... MVEEE Chertsey agreed to overhaul \& modify the two ex-Transglobe skidoos. " 1 .... Expedition allocated Unit I dentity Numbers for Army \& RAF stores.

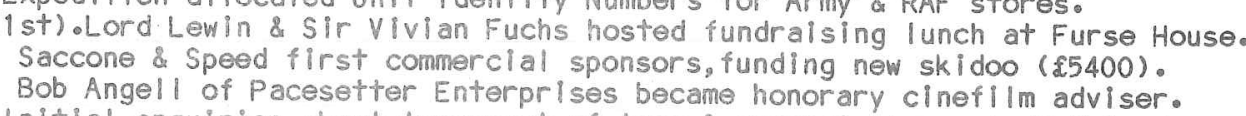

" " $\quad \ldots$. InIt al enquiries about transport of team \& general stores to Falk sands.

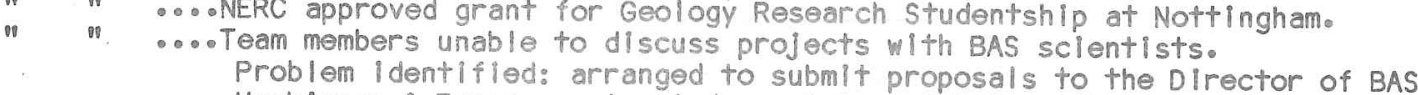

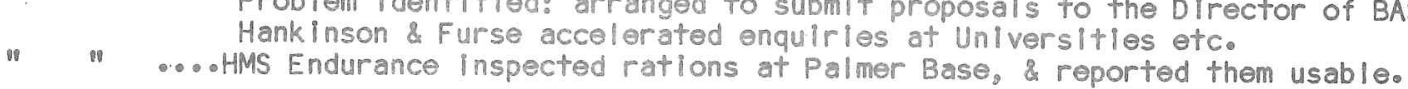


983 March. Request for assistance in 83/84 forwarded to CO HMS Endurance.

" " ... Corefence council instruction published seeking 25 volunter

Further selection to First Summer (8 team +3 reserves), \& 117 men). 3 team +6 reserves "carried over" to second summer, due postings etc.

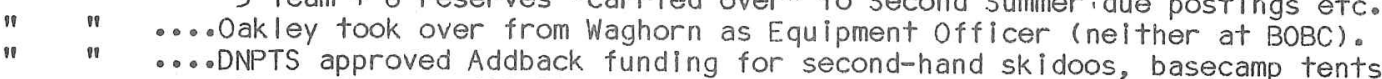
Furse tore up $£ 10,000$ Addback cheque (due payment before 1 Aprit). Furse tore up \&10,000 Addback cheque (due payment before 1 April).
Will ams \& Glyns pretended they had torn it up, and accepted it. Co Endurance agreed in principle to assist expedition,

" $\quad$ but with particular reservations about carriage of gasoline.

" " $\quad$...potential alternative freight arrangements reviewed \& some canvassed.

" " $\quad \ldots$.... Twows skidoos bought from Transglobe Expedition, taken Sloane square to MVEE.

1173 ....Draft bid-letters for Addback $83 / 84$ sent to all team members to use.

"I

" " $" . .$. Beattie, de Silva \& Stuttard attended sympos lum at BM Natural History

....Prot.Baker \& Furse interviewed 9 shortlisted applicants for studentship.

" June..... Ringe selected (after some hiccups) for Geology Research Studentship.

" " $\quad$ "...TransAntarctic Association granted expedition $£ 2000$ (had asked for £750 !). Glossy coloured expedition brochure produced by DPR(N).
arranged facilities at RGS for Second Summer selection intervied . Arranged facilities at RGS for Second Surmer selection interviews.
$\ldots$ Detailed rations budget drawn up. Increased numbers discussed with DGST(N).

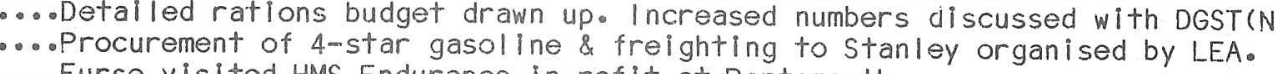
Captain McGregor agreed to increase 15 \& OW teams to 10 each.
Cand to

" "... Coformal bid for ship's support submitted to Hydrographer \& CO Endurance.

1983 July....... Furse visited BAS to brief Brazilians on Elephant Istand (no transport1).

nutl ine programme included support to JSE.Outward journey through Panama.
out

$" \quad " \quad \ldots$ Endurance agreed to embark ten 45 gal drums of gasoline in Chile.

" " $\quad \ldots$ Anews letter No.3 sent out (25 team members + Cos + 43 external addressees).

1983 August.... Sclentific project sheets submitted to Director BAS for approval.

- Two weeks summer Training at JSMTC Dundonnell for is and OW.
First Summer Party now 9 team members to reserves; Winter Party $7+3$.

First Summer Party now 9 team members to reserves
Advertised to fill vacancies after 2 with

. Requested approval for Atkins \& Corbett to remain over the Winter.

Requested Diplomatic Clearance for 15 Party outward through Chile.
.

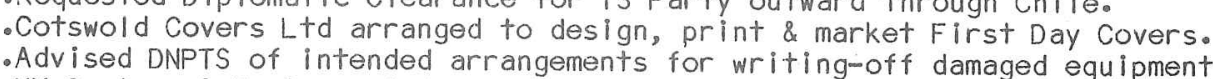

HM Customs \& Excise ruled no VAT exemption for goods delivered in UK.

1983 September. Winter Training dates changed to January (for 25 with ow).

" " $\quad . . . N o r s k$ Polarinstitutt agreed wording of Belgica plaque (at 3rd attemptl). - Lumsden released to assist HIII pack ing stores at RM Coypool.

Hankinson booked visit to Valparaiso confirmeda from

" ...oflag Officer Medway hauled down his flag. Furse largely free for JSE work.

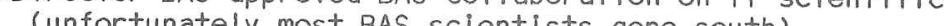

" $\quad$ "...(26th-28th).Selection Interviews for Second Summer at RGS.

" $"$....Newsletter No.4 sent out (42 team members + Cos + growing external list).

...Trathen made informal agreement with RM Eastney for printing Final Report.

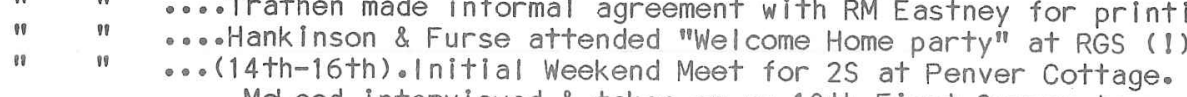

$$
\text { Mcleod interviewed \& taken on as 10th First summer team member. }
$$

De Ger lache first met other team members.
(16th-21st). Pre-Departure Meet for 15 at Penver cottage.

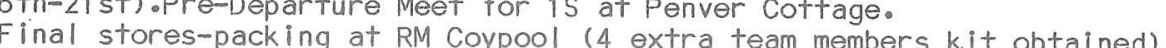

. Outboard Motors 3-day course at RM Poole, arranged by Worrall.

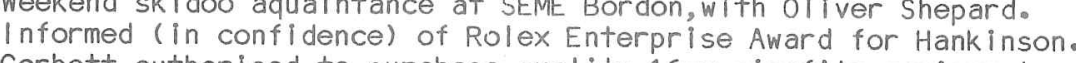

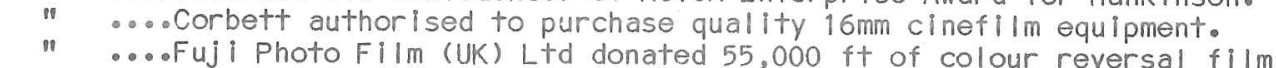

1983 November.(1 1 st).1S Stores embarked in HMS Endurance at Portsmoutho
Arranged to ship excess ow stores south in SS Andalucia Star.

" " $\quad \ldots$ Atkins 2 week survey course at school of Military Survey, Hermitage.

" $\quad \because .$. Agreement finalised with Chr is Bazalgette/John Spencer for fund-railsing

... Turse signed contract for book with Croom Helm Publishoryons

. Problem identified - uncertainty due low priority on trooping flights.
Asstochief Defence staif Personnel \& Logistics approached for influence. DGST N approached for travel in Royal Fleat Auxiliary.
RFA Resource (Captaln MCLaughi in) agreed to transport

" " $"$ ". RPFAs programmes changed due Lebanon crísis. Resource not golng to Stanley. " "...RFA Fort Austin (Captain McLaugh in in new shipl) of fered team transport.

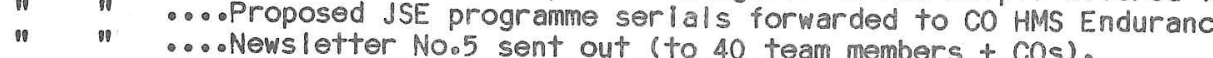

1983 December Newsletter distribution handed over to Ball (100+ external coples sent). st). Furse briefed HRH The Prince of Wales.

Waghorn's end date at BRNC settled.(for July

dministration, Treasurer \& Sciences tasks handed over to 25 . (a)

" $"$ ".oofurse vistisited BAS Cambridge, discussed radio uith Deputy Director.

" -... Formal request to BAS for radio IInk through Faraday Base.

" "...ofinance \& insurance arrangements for civilian team ment bul letins in

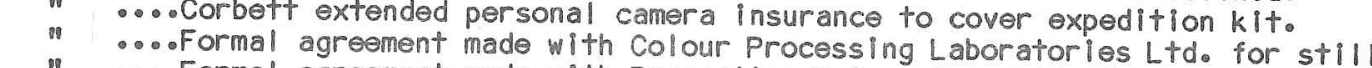
Formal agreement made with Pacesetter Enterprises $L$ tdo for

" " $\quad$ "..opre-expedition physiological tests for Winter Party at INM.

ACDS.P\&L advised trooping out (RFAs changeable; Movements optimistic). Decision on OW outward travel handed over to oakley.

Waghorn took over UK Leadership.

is Party departed from Hethr Hotel.

" …uㅏ. " $\quad . .00$ okley arranged OW outward travel in Fort Austing direct UK-Stanley.

1984 January... Two weeks Winter Training for is \& oW teams in Cairngorms.Suitable weather Waghorn unable to attend due Job at BRNC). $2 S$ team now 14 team members + Ringe to 4 reserves. (7 boats; rest land).
Evans two week survey course at School of Millitary Survey, Hermitage. HMS Endurance longcast received. Ball arranged is return travel trooping ship \& flight from Stanley. BAS agreed to pass radio bulletins through Faraday \& Cambridge to DNPTS.

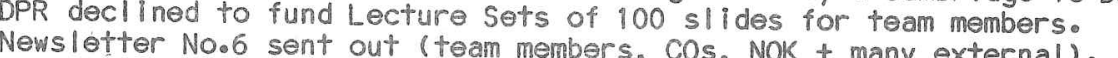
Ball made agreement with Tony Bray for marketing phllatelic covers.
B. Second Summer team stores meeting in London. Press Conference \& farewell party for OW team in Port

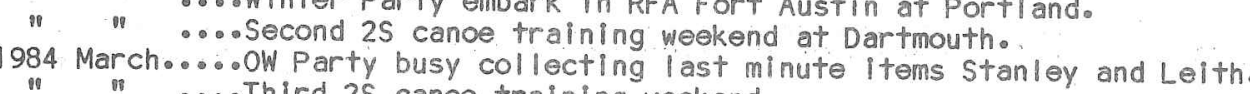

1984 April ..... BAS Stanley of fice closedeBulletins now by facsimile Faraday to Cambridge. Hall \& CPL began processing is photographs.

" ". ....Hankinson \& Morris visited to Geneva to receive Rolex Award for Enterprise. "1" ... Fourth 25 canoe train'ngal thank

" " $" . .$. HMS Endurance returned to Portsmouth. Greenway collected is return stores. " " ... Waghorn submitted request for assistance $84 / 85$ to Endurance \& FOF.3.

" ....Two withdrawals from 2S. Canvassed for extra volunteers in Service papers. 
" accelerated including raffle for evening with Miss Brabant or an explorer

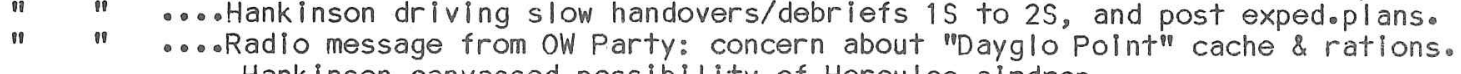
Hankinson canvassed possibility of Hercules alrdrop.
service stores began arriving at SEME Bordon. Greenway checking on receipt.

" " ....0perators course on inflatable boats at RM Poole. Hank inson began Staff Navigation Course, continued search for lost samples.
Ashcroft withdrew. Clements took over PR \& Fund-ralsing (4th in 8 months).

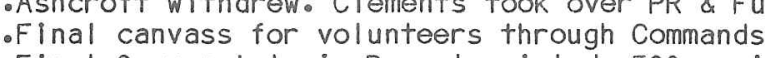

" " ....First Summer Interim Report printedo 300 coples distributed by Hankinson.

1984.August.... (31 st). Selectis arranged Interviews for 6 applicants in MOD Building.

" " .....Lewis relleved in HMS Juno, giving him more time for JSE stores work

" " "...Waghorn finished at BRNC, appointed to DNPTS additional for JSE.

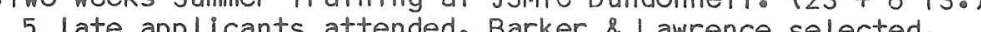

$2 S$ team $f$ Inal ised: 7 Boat Party +9 Land Party + Ringe.

"198. "... Hank inson continued search for lost is biological collections.
".

" " $" . . . P$ lessey Electronics Ltd. enquired whereabouts of 3 Clansman sets on loan. Waghorn visited Endurance to discuss detailed plans.
Radio message sent instructing OW Party all at Metch.Pt. for changeover. Radio message sent instructing oW Party all at Metch opt. for changeover.
$2 S$ plans to be based on all landing at Metchnikoff Foint.

" " $\quad$ "...Ball def ined and arranged 25 outward travel (trooping flight \& ship).

" " $\quad$ "....RM Eastrirst Summer Biological collections finally located (at RAF Lyneham).

1984.0ctober..(4 th) . Hank Inson briefed HRH The Prince of Wales.

Formal request to CBFFI for facilities for $2 \mathrm{~S}$ in transit through Falklands.
Evans' evacuation not if fed. HQ 1 Group Aeromed cal Evacuation Section fixed.
$2 S$ Team Training/Stores-packing week at SEME Bordon.

is Reunion at RGS (Young Explorers Trust Welcome Home Party).

1984. November... (31 st). 25 stores embarn submitted interim in Endurance at Portsmouth.

" $\quad$ "...P Hessey Electronics Ltd agreed to extend loan of 3 Clansman radios for $2 S$.

" " $\quad \ldots$ Hank Inson took over ALL administrative tasks from, $2 S$.

Evans (just returned) handed over coples all ow Party radio messages.

$"$ " ... (26th). Second Summer team departed from RAF Brize Norton. Waghorn confirmed oW Party return journey details, investigated $2 S$ return.
2 weeks training in camp \& canoes. Hughes lone walkabout - hmmph!

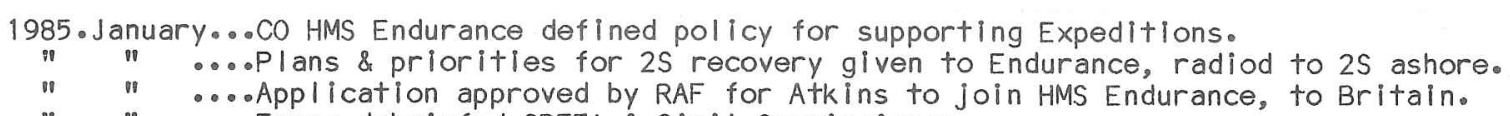
Application approved by RAF for Atkins to Join HMS Endurance, to Brital

" $\quad \ldots$...SNOFI confirmed airbridge/air-trooping return Journey dates for $2 \mathrm{~S}$.

" $\quad \because(28+h)$. OW Party post-expedition physiological tests at INM.

Times, Telegraph \& Guardian use upside-down Union Flag, pictures, Oh dear!
" $\quad . . .0$ Newsletter ( $31 \mathrm{~s}+$ ) sent out (team, NoK, COs \& 103 external). OW prelimoreport

" " ....Greenway's evacuation notified. Aeromedical Evacuation Centre fixed.

1985. February.

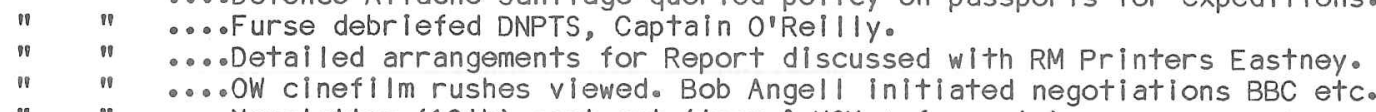

" " $\quad$ "... (22nd).Request recelved from $2 S$ for 3 outboard gearbo

fixing 2 complete motors from PSTO(N) Devonport, unable to fly out

1985.March.... (4th). News of Waghorn's crevasse-fal I and injury received via DNOA(E). Rescue actions are covered in narrative section of this report.
Only Rearlink action was informing NOK, and public relations at home. Telegraph informed 4th, but did not use the story. Press release issued 5th through DPR started major rescue story all media. Agreement with Syndicated Faaturas Ltd discovered, and formal I sed.

(18th). Waghorn, Clements, Gill, Martin \& Ringe arrived at RAF Brize Norton,

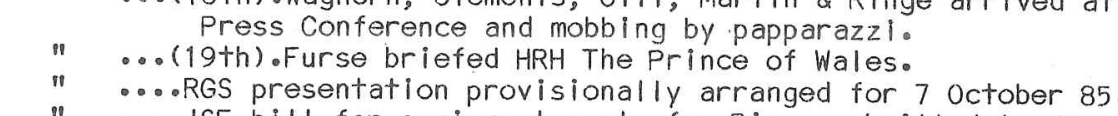

(t) Nottingham. 1985.April.... (8th). Waghorn, Greenway plus four met remainder 25 team at RAF Brize Norton. " " $\quad$ "...Personal reports on OW party forwarded to DNPTS.

" ....W return stores container arrived in Britain for months customs procedure.

$\cdots . .0$ Dixon \& Watt, Insurance Brokers refunded premium, cameras not insured.
Hank inson sought legal advice. ( (See November 84). Kimbrey (wIth Worrall) stood-by in RM Stonehouse for distributed.

\section{$-\infty-\infty$}

The following are some of the continuing administrative tasks foreseen.

1985.May......... Corbett \& Furse select OW slide lecture set of 120. CPL dup licate 15 sets. " " $\quad$ "...Hall, Waghorn \& Furse select $2 S$ Expedition s II de set (C800). CPL dup. 3 sets. " $\quad$ " $\quad \ldots$....Wurse hanhorn forward $2 S$ personal reports through Furse to DNPTS.

" .... Kimbrey and Worral unpack, clean and sort out OW return stores.

Stores on loan returned to (Service or civilian) Owners. PSTO(N) Devonport inspect \& assess worn and damaged Service equipment. for lost or damaged equipment.

" $" \ldots . .2 S$ return stores container arrives in UK for customs. 1985.June....... ak ley, Kimbrey \& Worrall go through the whole hoop again on return stores. $" \quad$ HMS Endurance returns to Portsmouth, Atkins \& MCLeod onboard (t ski idoos?) 1985.July....... Furse forward book manuscript to croom Helm Publishers.

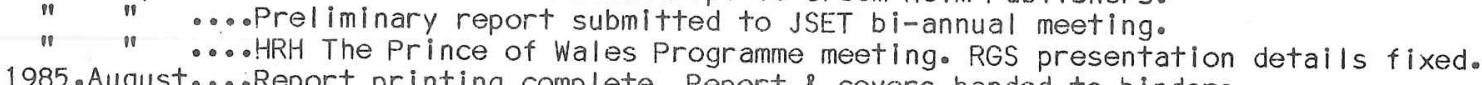
" "....Report binding complete, ready for distribution thro' team at reunion. $1985 . S$ September (27th-28th). Expedition reunion at Apol lo Hotel, BIrminghamo
View photographs, equipment sales, financial statement/handover etc. 1" "...(28th). . Furse to USA ref work, unt11'5 th October.

1985.0 ctober...JSE Presentation at the RGS (planned for Monday 7 th).
1985 . November.(13th \& 15th). JSE Presentations to the RSGS at Glasgow \& Edinburgh. 1986.February. . Bill receives Gold Star Award from Daily Star.
1986.April... "Antarctic Year, Expedition to Brabant Island" 1987............Wind up Expedition Fund; present accounts to DNPTS. 
The great majority of team members were selected from applicants responding to
volunteers printed in Defence councli Instructions. Selection was in four main calls for volunters printed in
stages over the $18-22$ months preceding each phase of the expedition.

1. Applicants had to obtain approval from their Commanding officers, whose endorsement was required on their initial written
application. (In many cases this involved cos obtaining clearance from central appointing/drafting/posting authorities).

2. Written applications included personal details such as age and and canoeing, scientific qualifications or interests, and experience in varlous support activities such as doctoring written applications Furse selected a shortl ist for intervlew,
calling about twice as many interviewees as were required in the squad.

3. Selection Interviews were held at the RGS with a panel of 4-5
interviewers. In October 1982, Cdr Malcolm Burley RN RTdo chaired the Selection Committee, comprising Furse, Waghorn, Oakley and Chlef Petty officer Stove Oak ley. Each shortl isted applicant was intervlewed for 15 minutes. At the end of the 3 days interviewing, selection was agreed and

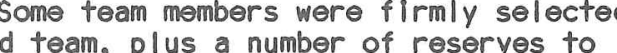
forming $40-70 \%$ of the planned team, plus a number of
form a total squad of about $150 \%$ of the planned team

4. Over the year plus leading up to departure, reserves were

progressively confirmed as team members, as they demonstrated
their suitability (primarily during the 2 week winter and summer (t) year, and in practice it possible to increase the original team sizes so that all sultable

Furse had selected Waghorn (an old friend), and Oakley (earma

Ringe was selected in mid 1983 by the normal Universities' routine process for selection of post-graduate research students. Morr is was recruited in January 1983 after
no sultable service doctors had been recommended. De Gerl ache was recrulted in 1983 after Furse had contacted the Belgian Antarctic Committee about a commemorative plaque.

Before each of the three phases departed, withdrawals of reserves reduced the squads below the maxice numbers approved by HMs Endurance. Late recruiting campal gns wer were interviewed. Mcleod jolned the First Summer Party in this manner in October 1983. Barker and Lawrence Jolned the Second Sumner Party aftor sumer Trainling In August 1983. Similar shor Summer, de Gerlache and Lumsde
extending from the First Summer.

Although the three teams contalned many quite inexperienced men, and no widely recognised " nstars", they proved excellent coll lectively and individually. The progressive
selectlon was confirmed as a satisfactory method and in particular the real value of

Note on Leadership of Parties on the Island, \& the Narrative Reports. One of the few rules of this expedition in the field was that every group or
party must have one recognised Leader. Choice of leader depended upon the main activity,
appropriate experience being the main factor. Through the course of each phase, most appropriate experience being the main factor. Through the course of each phase, most
suitable team members were given an opportunity to lead a party. Service rank was ignored in case of doubt the rule was that the el dest member of a party would take over, or would nominate another as leader (in fact no such doubts ever arose). Throughout the foll lowing narrative sections of this report, the first name is the Party Leader, other members the expedition would simply not happen.

BASIC RATIONS AND FUEL FOR FIRST SUMMER AND WINTER.

January 1982. Rations salled MV AES Gravesend to Port Stanley (comesend Docks.

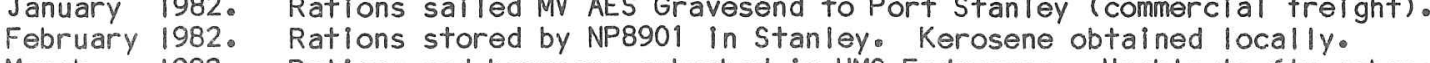

March 1982. Rations and kerosene embarked in HMS Endruance. Unable to fly ashore onto Brabant due 3 days bad weather.

January 1983. BAS staff Inspected rations, repor

March 1983. Supply Officer Endurance inspected rations, found them usable

January 1984. Rations and fuel embarked in Endurance, transferred to Brabant $\mid$ s land. $\frac{\text { 4-STAR GASOLINE FOR FIRST SUMMER AND WINTER。 }}{\text { JulY 1983. RAOC Petroleum Centre tran }}$

August 1983. West Moors to Southamptono $\begin{aligned} & \text { Gasoline salled in STUFT ship to Port Stanley. } \\ & \text { Stored by Falk }\end{aligned}$ (Drums shipped south in Endurance February, March and Dec. 1984)
December 1983.
south and from Shel| ChIle entarked Endurance Valparaiso, shipped

FIRST SUMMER GENERAL STORES

Nover

December 1983. Bulk stores moved from hold to hanger at Valparaiso. (Hankinson hit by

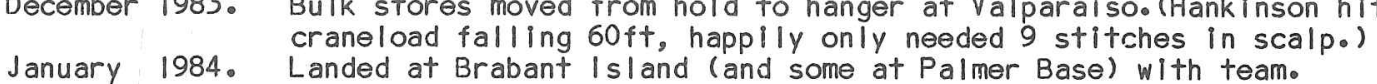

FIRST SUMMER TEAM. (10 Men)

December 1983.
Paris \& Commerclal airflight from Heathrow to Santiago (changing at
Parain Santlago to Valparalso. (Total 8 days in Chile).

January 1984. Landed at Brabant Island (and Boat Party at Palmer Base)

WINTER GENERAL STORES

Stores found too much for Endurance hold on loading.

December 1983. Shipped south in SS Andalucia Star from Southampton to Stanley.

Embarked in Endurance at Stanley. Some stores landed on Brabant
Island that month. Skidoos \& other stores transferred from Palmer to

March 1984. Remainder of stores Ianded on Brabant I sland with Winter Party.

WINTER TEAM ( 9 Men)

February 1984. 17th - Embarked in RFA Fort Austin at Portland, sal led to the Falklands March 1984. 8th- Hell copter transfer to Endurance at San Carlos. 2 days Stanley. Sailed in Endur tre vila South Gornce at san Carlose 2 days stanley.

EXTRA RATIONS AND FUEL FOR DECEMBER 1984.

September 198. Collected in Stanley by Falklands Islands Logistic Battalion.

October 1984. Embarked in RRS John Biscoe.
November 1984. Landed at Metchnikoff Point, when evacuating Evans.

FUELS FOR SECOND SUMMER PARTY.

$\begin{array}{ll}\text { August 1984. } & \text { Freighted south from Britain in Mod contract cargo ship. } \\ \text { September } 1984^{\circ} & \text { Stored by Falk ands Is lands Logistic Battalion in Stanley. }\end{array}$

(984. Embarked in Endands lslands Logistic Battarton In Staniey.

RATIONS AND GENERAL STORES FOR SECOND SUMMER PARTY.

(19. Transported from RNVD Botley \& SEME bordon etce to Portsmouth.

November 1984.
Endurance sail led to Stanley hold.
December 1984. Stores landed on Brabant. Is land with Second Summer team.

SECOND SUMMER TEAM

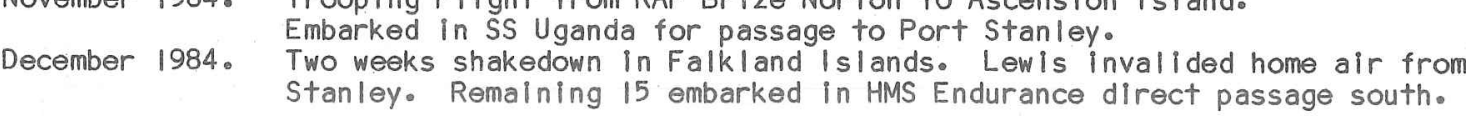




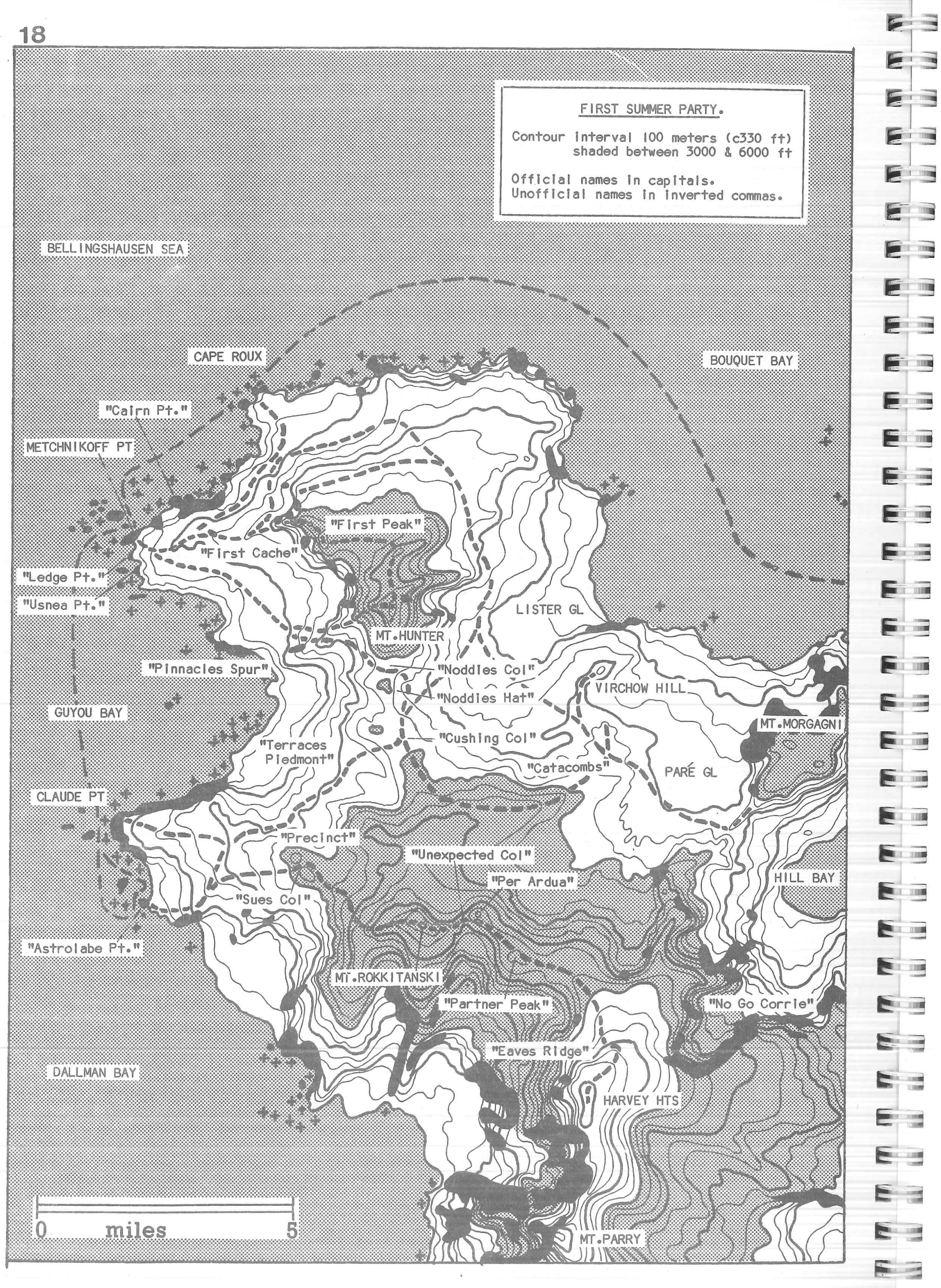

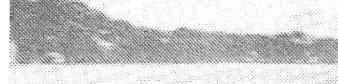

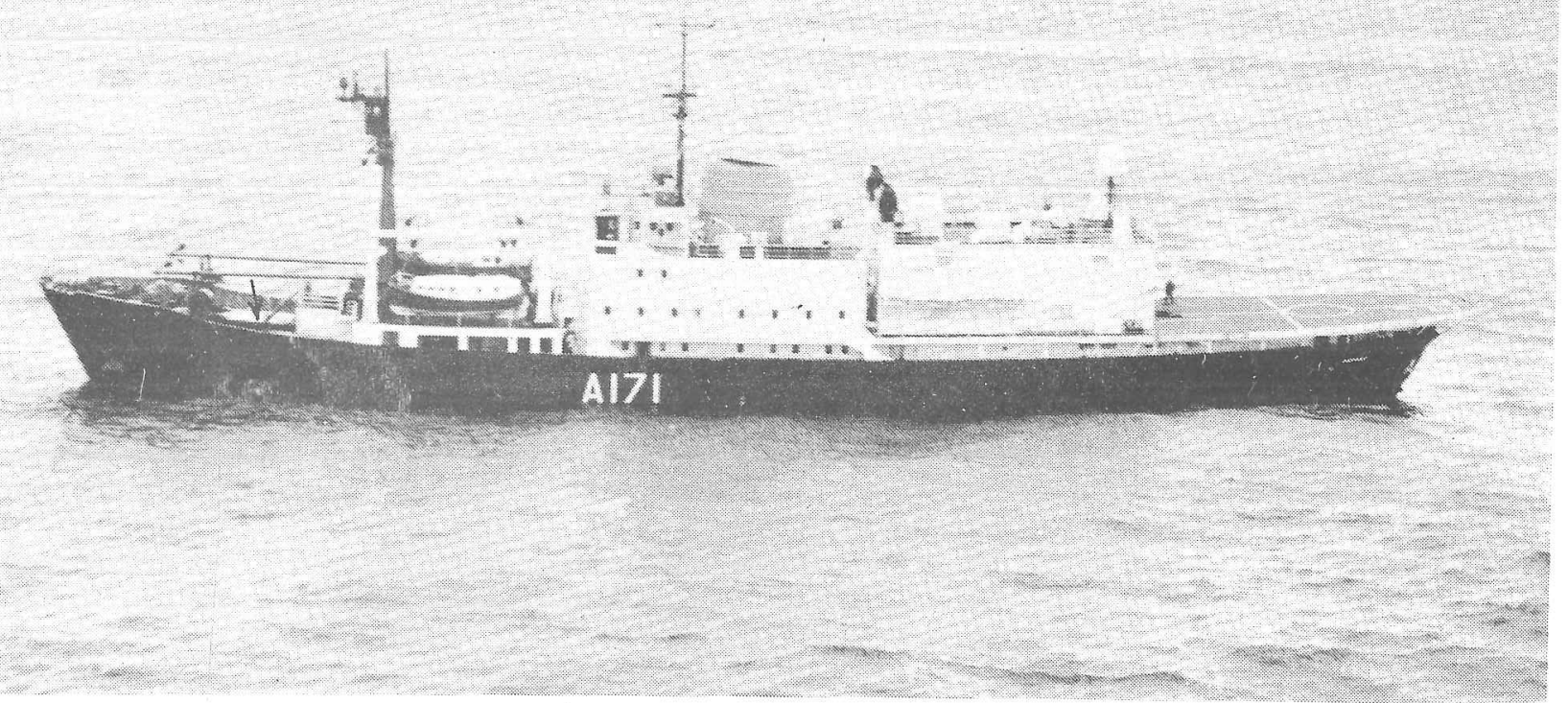

HMS Endurance. Good weather for flying and for moving gear from the hold to the flight deck aft.

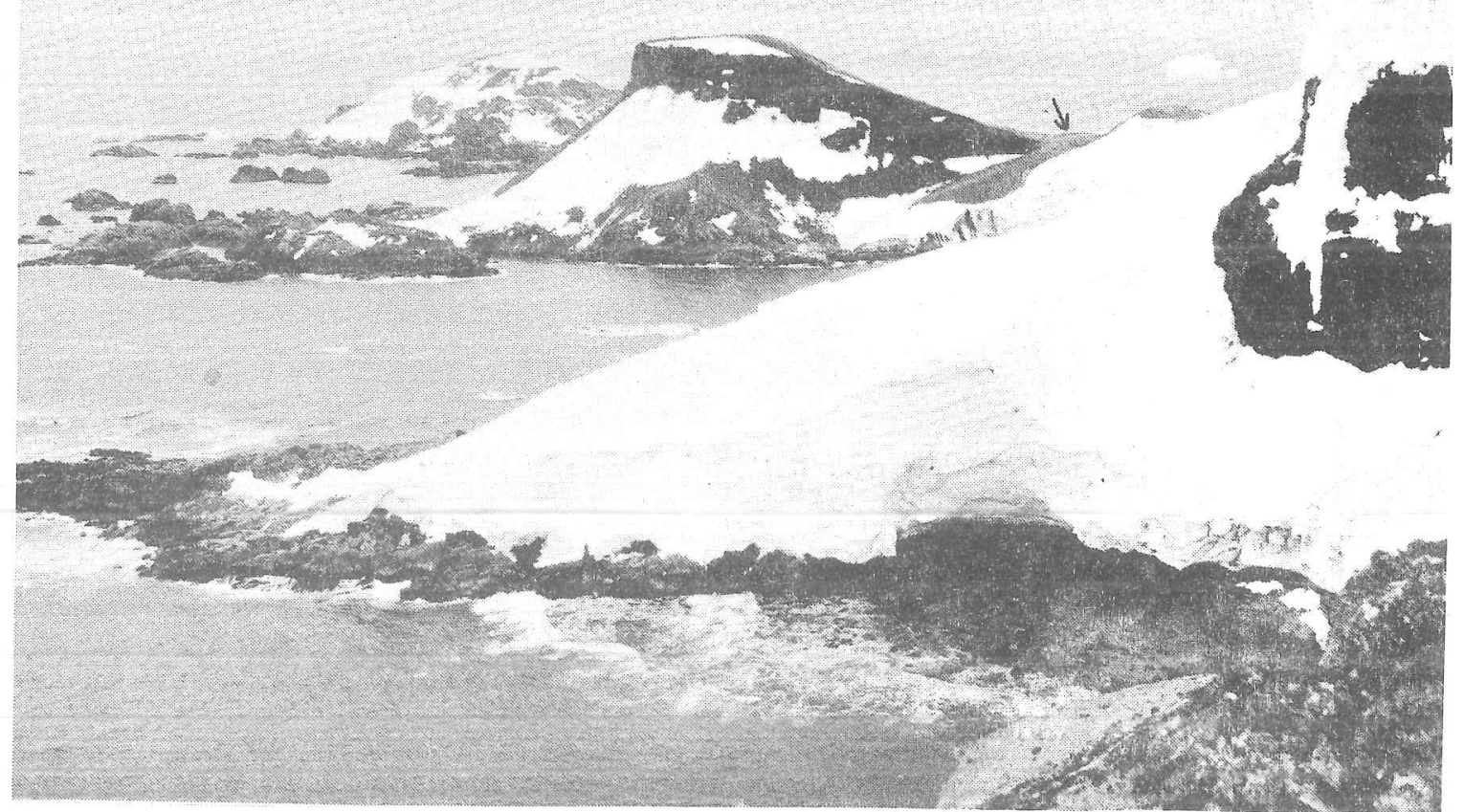

Metchnikoff Point from the' 'South. Base camp was on the $150 f t$ col arrowed 


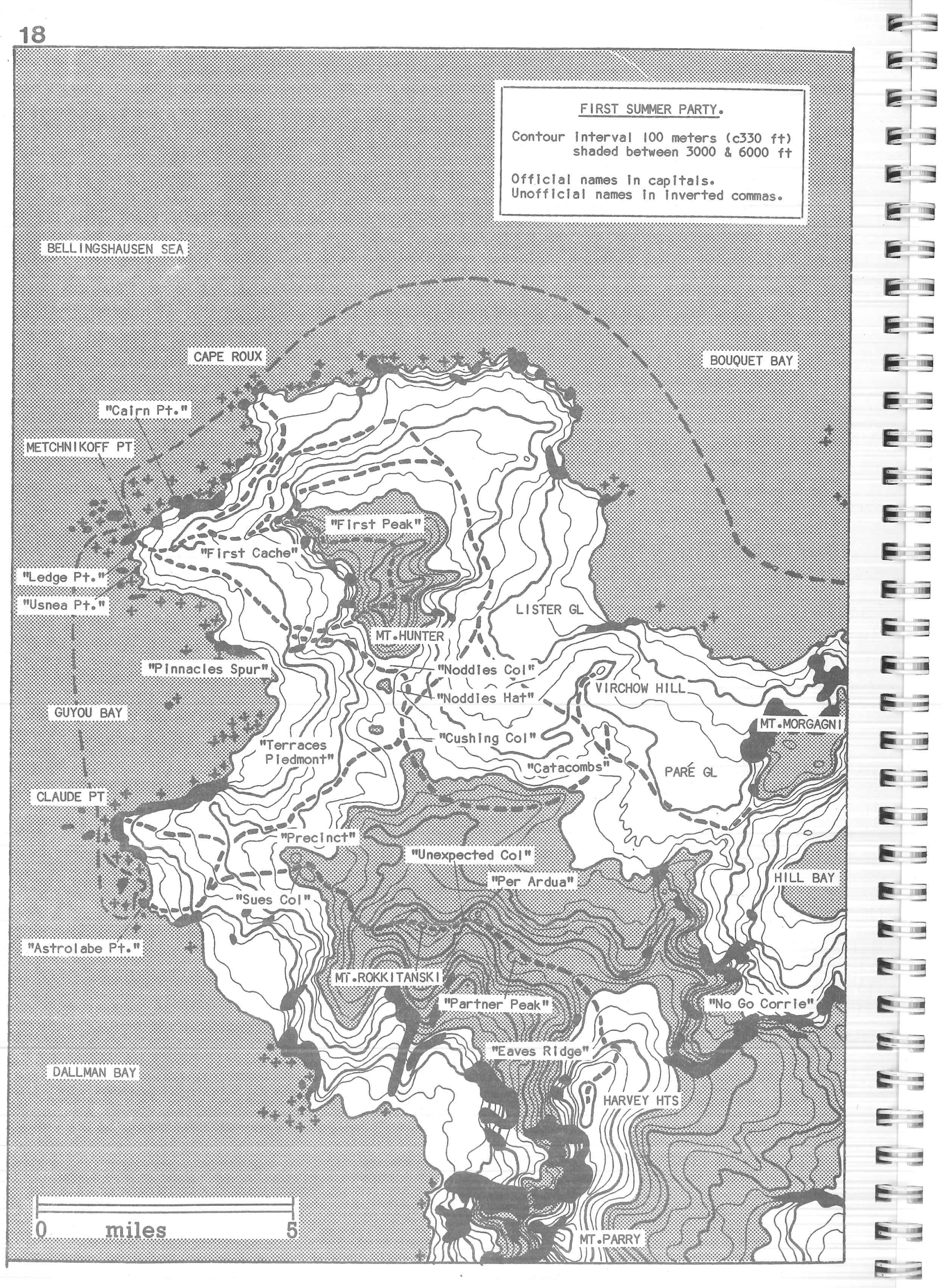

2

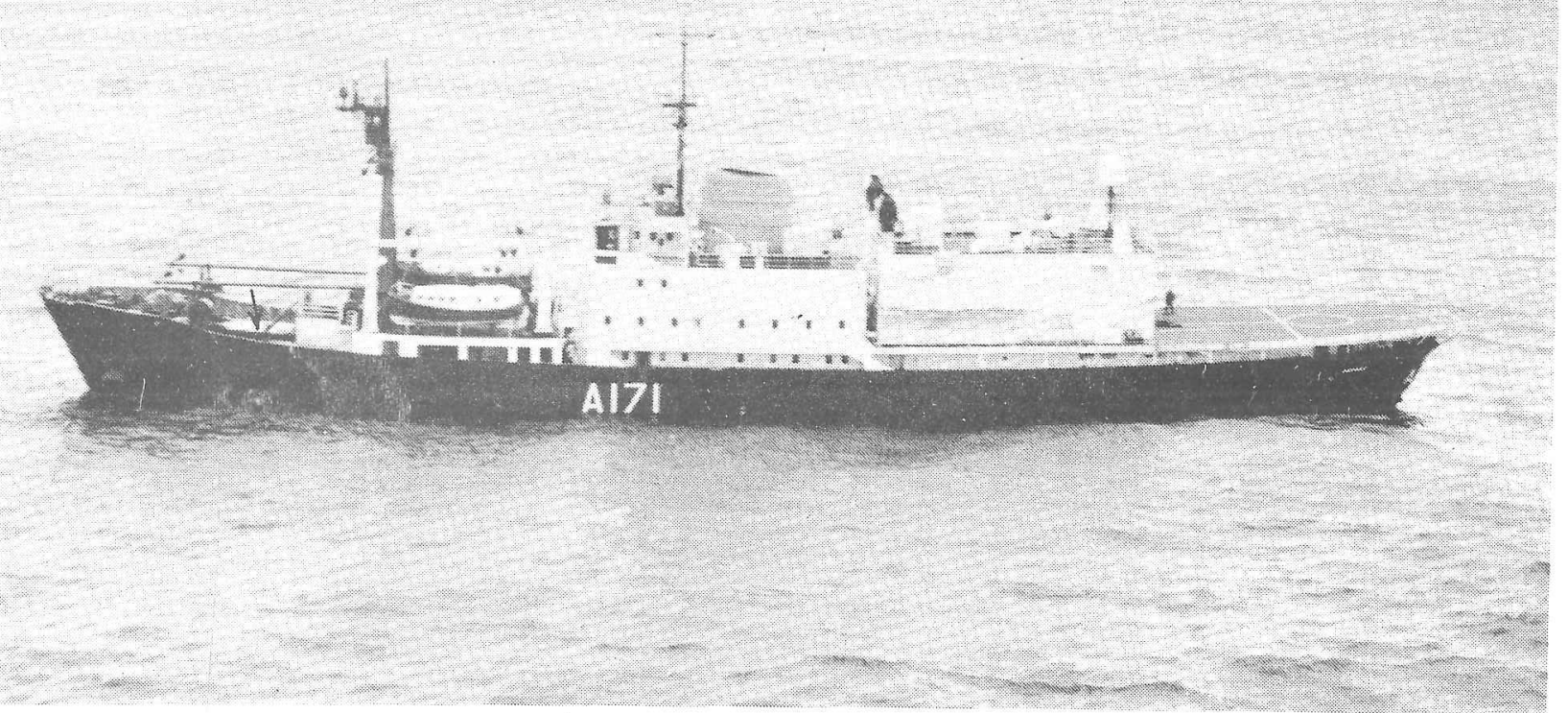

HMS Endurance. Good weather for flying and for moving gear from the hold the flight deck aft.

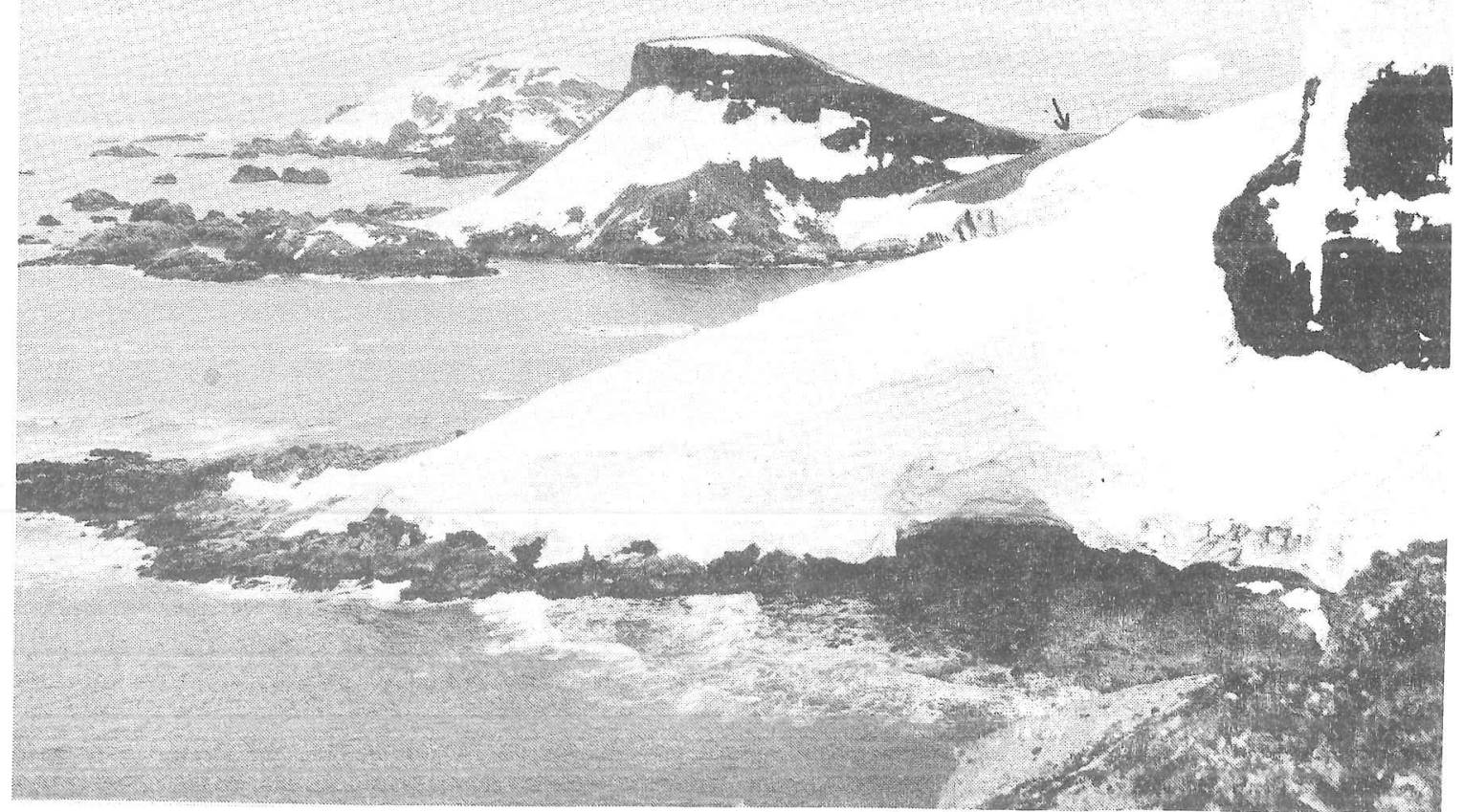

Metchnikoff Point from the' 'South. Base camp was on the $150 f t$ col arrowed 


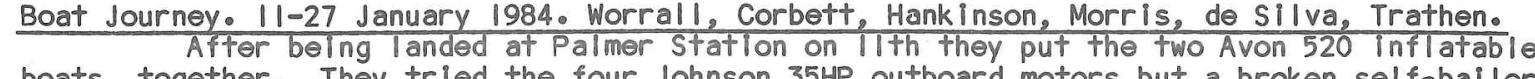
boats together. They tried the four Johnson $35 \mathrm{HP}$ outboard motors but a broken self-bailer
on one of the boats took up the next day, to allow the glue to cure. On Friday 13 th they
left heavily laden, watched by the incredulous station crew, repeating the departure thrice left heavily laden, watched by the Incredulous station crew, repeating the departure thrice
for Corbett's Fllmo They motored east through a choppy sea in the Bismarck Strait. Keeping well
offshore they missed Cape Lancaster and instead turned up the east side of Wiencke I sland. Reallising their mistake they rounded Fridt of I I land and came back, then up the east side
of Doumer I I land to land at Port Lockroy. They spent a day there in Ilorlous weather of Doumer Island to land at Port Lockroy. They spent a day there in glor lous weather
photographing birds; Morris incited Hankinson to swilm, and de Silva found a spanner for stove pump-valves. 0 ing moved on north, turning the blind corner of fabul ous Neumayer
Channel. After fliming the boats in brash toward sunset, they landed at I ceberg Point. Two days were then cancel oarly on 18 th into Gerlache Strait, passing immense I cebergs with
calls for "Thake 42, Scene 12 . Action" After stopping at The Walfs for lunch, they approached Brabant island in thick brash, with leads opening and closing in a following

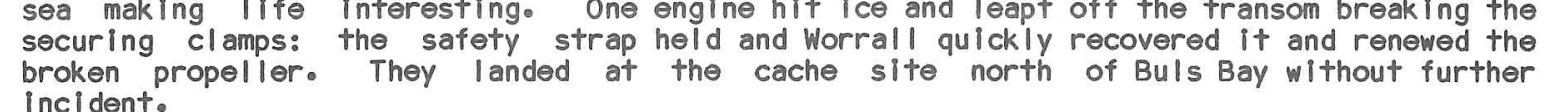
They were stuck there for 7 days, apart from one boat reconnalssance northward curtalled by a snowstormo. They mustered and sorted out the stores into two caches,
Trathen marked boulders on the intertidal beach, which gave the site its (unofficlall) name of mayglo Point" . Hankinson \& Corbett skled up to $1200 \mathrm{ft}$ to reconnoltre the start of the over and route to basecamp, but agreed that the journey would be quicker by boat. As there a run for 27 th, despite marginal sea conditions and still unsettled weather they made Point. Bouquet Bay was packed with large brash ice but they progressed steadily, with one scare when two Humbacked Whales suddenly reared up right in front of the lead boat and 列 disappearing in the troughs, and the swell thundering onto the cliffs, and sending towering
columns of spray into the air as they motored between the stacks around Cape Roux and on
into Metchnikoff Point at midnight. Their total distance covered was about $140 \mathrm{miles}$, including detours, a great
achievement in open boats in the Antarctic. (Boating from scientific bases is strictly
limited). The seaworthiness and rellablity of the boats and engines had been well demonstrated, and Worrall's meticulous preparaty
Basecamp. $28-31$ January 1984. Whole Party.

The weather smiled while the Batyo Party sorted out their gear and practised roped sking on visits to "Skua Bluffm and "Calirn Point" for botany, bugs and geology.
Sclentific work was progressed around Metchnikoff point, and plans were made for the middle
part of this phase, with two parties exploring south, returning to basecamp in mid-February
before an attempt on Mount Parry. Basecamp Trio. 1-16 February 1984. Furse, Corbett, Hankinson.

complete the tho exploratory pulk partles left late on 31 January. The trio remained to
initial botanical survey of Metchnikoff Point before catching up the West After completing the botanical survey they set off in a boat on 5 th. Crossing
Guyou Bay they found a way through the reafs off claude point, only to find no practical site at "Astrolabe point".
They sighted two tents on the skyline above, then On 6th they set out with one pulk to go overland to "Astrol abe Point". Camping below Mount Hunter, their Nova tent broke a pole in an easterly bl izzard gusting above a
measured 55 knots. Desplte digging out, walling up, bolsterling the broken ends and sltting up supporting the tent, it was a total wreck by breakfasto. They cached the pulk and tent

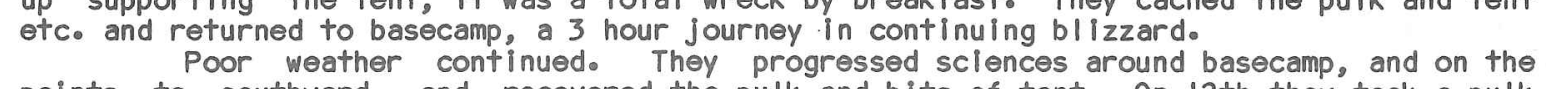
points to souther recovered the pulk and bits of tente on $12^{\text {th }}$ they took a pulk success. After 3 days of rain (4 inches recorded) they pulked back to basecamp on 16 th,
to find no one else at the rendezvous. At 1950 the unprotected Nova tent blew out, leaving to find no one else at the rendezvous. At 1950 the unprotected Nova tent blew out, leaving
two newly-pitched Antarctic pyramids. Ten minutes later 3 figures with a pulk appeared East Side Story. 1-16 February 1984. Trathen, Atkins, de Silva. hauling one pulk around the north side of Mount Hunter, camping the first superb weather Roux, and then crossing Roentgen ridge to camp on Lisfer Glaclere on 4 th they camped at
$2500 \mathrm{ft}$ on the ridge between Lister and Pare Glaciers, and ascended Virchow HIII (2300 ft) They were then held up on "Catacombs Plateau" by dense cloud for 6 days, while
6 ft of snow fell, leaving the tent hidden in a perfect windscoop. They went onto two-thirds rations, In a brief clearance one day Trathen and Atk Ins climbed nearby "Kernow HIII"
(2300ft, only 2 full pitches, but a Grade IV Iceface, which slumped 6 inches bodily while

they reached "Morgagni Col". However starting up the ramp-like ridge, the deep fres on 13 th they started homeward up the ridge, but pitched camp at $3500 \mathrm{ft}$ after a blizzard as they traversed around, and pitched camp at about $3100 \mathrm{ft}$. With spindrift

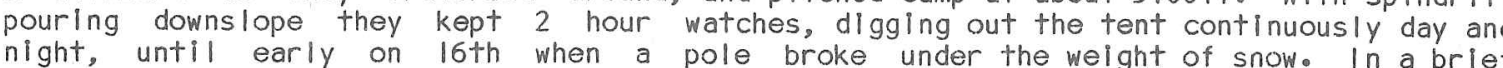
clearance they broke camp and felt their way down the ridge until barred by icecllfifs approaching "Noddles Hat". They doubled back onto L Ister Glacier and came over "Noddles
col" to find the bamboo markers above "Pinnacles Spur". They reached basecamp late that evening after a very hard day pulking over 15 miles in foul conditlons. in high spirits. They had developed the basic techniques which were used thereafter, with
little refinement, whenever using 3-man pulks. They had also (just) met the deadline, set to meet Endurance's pre-arranged visit next day. HMS Endurance Visit. 17 February 1984.

On 16 th Endurance had re-embarked the skidoos and associated kit (but not the
rations) from Palmer stotion. rushed into a Wasp to organise stores loading: 3 skidoos, 2000 cigarettes, more fuel drums and some general stores were flown ashore. Captain McGregor, Sir Rex Hunt, and his
secretary sue (the first girl on Brabant I sland?) were flown ashore and formally the expedition's Sub Post office in a sodden, dirty Pyramid: the first cancelled JSE Cover was posted to our Patron, HRH The Prince of Wales. Trathen returned and the VIPs left, other stores could be landed. Nor was it possible to launch a Wasp to visit "Astrolabe the Structaply Hut, plus extra food and fuel and some oyglo point" and managed to fly in embarked Winter Party gear shipped out in ss Andalucia star. Uncertainties abontey she had embarked Winer Party gear shipped out in SS Andalucia Star. Uncertainties about equipment
landed at "Dayglo Point" were to prove a problem at and after the changeover in March). $\frac{\text { Base Camp. 18-21 February 1984. Furse, Atkins, Corbett, Hankinson, de Silva, Trathen。 }}{\text { Foul weather returned later on } 18 \text { th, culminating in } 80 \text { knot winds and } 2 \text { inches }}$ of rain on 20 th. Base camp (on the glacier) was bare ice, with $3-4 \mathrm{ft}$. snows and inths under
the tents and rivers of meltwater, requiring constant replacement of ice-screw "tent pegs" wearing crampons. The absence of the West coast Party (who had no radio) was causing meet them en route, otherwise to start searching, following their calrned messages.
mon 21 st the weather eased: two loaded pulks were relayed up to the skyl Ine at $600 \mathrm{ft}$, before camping at the west
occupying the beaches.

Cosm!c Campsites Ltd。22 February-14 March 1984. Furse, Atkins, Corbett, Hankinson,

They left on 22 nd with two 3 -man pulk teams travelling in loose company, heavily
loaded with one radio, Beaul leu cinecamera kit and Bilora tripod, and 2 spare tents (Nevisport Bombproof and Snowline Conquest) as well as normal travelling kit. After two
days clag across "Footsore Pledmont" to a windscoop, then up the central ramp of "P innacles
spur" to camp in a blg crevasse called the Icicle Works, where Hankinson, Atkins and de Silva descended $70 \mathrm{ft}$ into the blue grotto below the tents. In better weather they crossed
"Noddies Col" next day, where a $7 \mathrm{ft}$ bamboo wand protruding 4 inches above the snow showed the West coast Party had gone that way. On 25 th spindrift helped them down from "Cushing Col" onto "Terraces Piedmont" and on to "The Precinct". A deserted 2-tent camp site sharpened the atmosphere of this iceblock ghost town: they camped in the maln street while
relaying loads through. Hauling out of "precinct Glacler" they found a snow-wall and abandonned bugs-samples: digging into the drift they found signs of a I tent $/ 4$ manday camp. Late on 26 th they camped above "Astrolabe point" 0 . Hank inson and de silva visited the message: they returned at midnight. Meanwhile Atkins had heard Hill transmitting to An aday from basecamp, but could not transmit back, due to battery charging defectso
Amediate attempt on Mount Parry was agreed. On 27 th, after cach ing the radio
and Nevisport Bombooof and collecting extra ratlons from "Astrolabe Point" they pulked and Nevisport Bombproof and collecting extra rat lons from "Astrol abe Point" they pulked rest day after 6 days hard pulking. The two Super Nova tents stood it well the the wert come onto two thirds rations to give themselves unt II 1 loth March. On $29+\mathrm{th}$ they pulked up to
$4700 \mathrm{ft}$ on the west face of Mount Rokk itanski, relaying in whiteout on havy snow Nest" campsitessive whiteout, snow and gales enforced three days stop at the "Eagle's March they got above the cloud, sighted Mount parry and unofficially named the spectacular west coast bay below "Prince William Bay". That evening they made the First Ascent of beyond. A recce next morning discovered unforeseen difficulties at "unexpected coll" preventing further pulking. While the remainder stayed in camp mending stoves, Hank inson
and Atkins crossed "Unexpected Col" and climbed "Per Ardua" (5700 ft) in intermittent whiteout, returning tired and bitterly cold. Caching the pulks and Snowline Conquest tent they skied on next day. Progress
was slow in whiteout, and de SIIva was feel ing weak: that evening they camped at 6oooft
underneath "The Eaves" on the north side of Harvey Heights. Skiling up to Harvey Helghts 

monoxide poisoning in the tent they shared with de sliva. The party reached the north

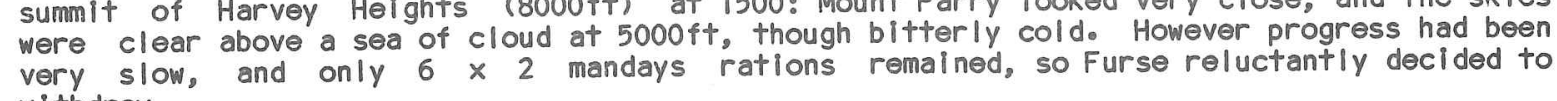

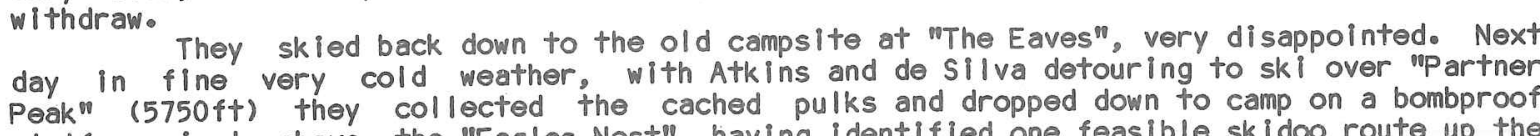

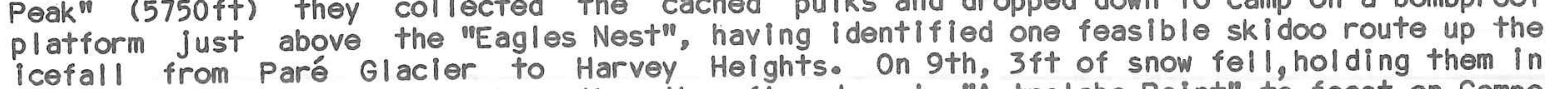
camp, but next day in superb weather they flew down to "Astrolabe Point" to feast on compo after two weeks on whount Parry had not been climbed, they had taken pulks to $6000 \mathrm{ft}$, made four high First Ascents and scrutinised the west coast by binocular. Corbett had also

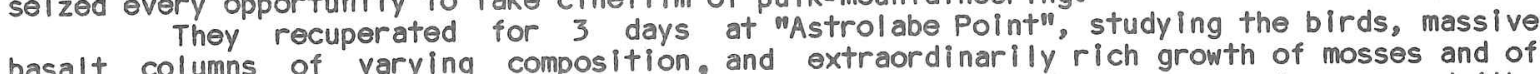
grass and pearlwort (both setting seed) and enjoying the first camp on snowfree ground (the campsite at $40 \mathrm{ft}$ height was surrounded by boulders on remarkably clean gravel, as if washed). Radio contact, was made with the other party, at basecampo it was decided that Hank inson vegetation, while the other three returned to base.

suffering an awful cough for 6 days) so they returned, after Trathen was very weak (after Link Party. 15-20 March 1984. Furse, Corbett, de Silva.

down to Claude point, to camp on the earth plateau at $700 \mathrm{ft}$, in rain. De Silva collected

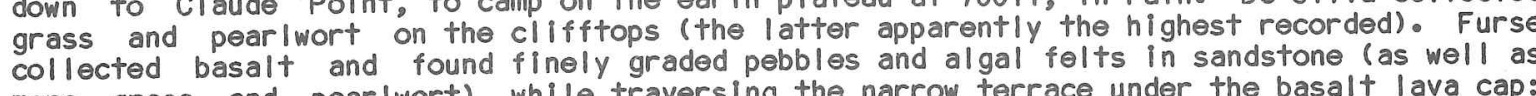
more grass and pear Iwort) while traversing the narrow terrace under the where some large driftwood was sighted.
Next day an hour was spent box searching for the pulk in whiteout before camping in a crevasse having mlse rising gale, but after several miles on a compass bearing were stopped by soft snow on a slope too steep to move the pulk, and found sanctuary in crevasse at 27ofed in they descended onto Lister Glacier. While Furse was reconnoitring (unroped) along a crevasse the wall dropped and he fell 20ft, but was un hujured though coughing blood for a while. Crossing "Noddies Col", they reached basecamp in the evening of 20 th. It was West Coast Party。 I February - 20 March 1984. Worrall, Hill, McLeod, Morriso at night for good snow. Breaking camp above "pinnacles spur" Morr is lost his sleeping bag, and did without thenceforward. They made the First Ascent of "Noddies Hat", and continued over Cushing Peak and "cushing Colm and thence across the "Trrace piedmont" and through by snow), they reached "Astrolabe Point" at 0100 on 6 th February. Morris collected samples for later extraction of hnverterrates. Without radion passed offshore on 17 th without visiting the pointo. Finally, on 20 th February they set out for Metchnikoff Point, leaving whe hit by and travelling light with only $4 \times 3$ mandays rationso one phortress outer tent, which was completely covered by a 50 yard drift behind their snowwall when they broke camp next morning. Travelling in whiteout they camped in "The
Precinct" on 21 st and at $3000 \mathrm{ft}$ on "Cushing coll" the next evening. There they decided to Precinct" on 21 st and at 300 "rt on "Cush ing hor had four main meals lefte Crossing Lister

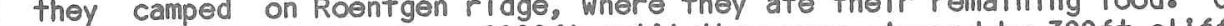
24 th they contoured west in cloud above $2000 \mathrm{ft}$ untll they were stopped by $300 \mathrm{ft}$ clifts dropping of the nor the ridge of hounth coast pledmont; then in hot sunshine they headed est again, finally reaching Metchnikoff Polnt at 2030, very hungry and dehydrated after covering 20 miles in the day.
For the next month they stayed around basecamp. They vacated the icy glacier campsite and moved to the stores dump flat, to a site that was rather besmirched by penguins, but was exquisitely chosen for all l-round shelter (and was used throughout the winter). They erected four Nova dome tents -2 sleeping tents, I mess tent. and I laboratory extracting and preserving about 350 samples. for Trathen by boat, but were turned back by a steep and nasty swell in Guyou Bay. Next day Morris and HIII broached and near IY capsized attempting to land at "Cairn Point" to collect Invertebrates. After a gap, Hill recommenced meteorological records on the March
McLeod set the tidegauge to work twice after damage by storms, and Worrall serviced the boat
and outboard motors. However for most of the four weeks rain inhibited play.

$\frac{\text { "Astrol abe Point" Party. 15-24 March 1984. Hank inson, Atkins, Trathen }}{\text { Trathen's cough (presumed to have been caught when he alone }}$ on 17 February) gave serlous concern, but he recovered, alliough too late to Endurance the changeover. They of the flowering plants and other vegetation; A A ins prepared a $1 / 2000$ map of the polint;
Trathen made thorough geological collections from the basalts and the smaller conglomerate Trathen matcrops.
outcris

$\frac{\text { Base Camp 20-24 March 1984. Furse, Corbett, HIII, McLeod, Morris, de SIlva, Worrall. }}{\text { These last days were mainly occupled with preparlng stores for the }}$

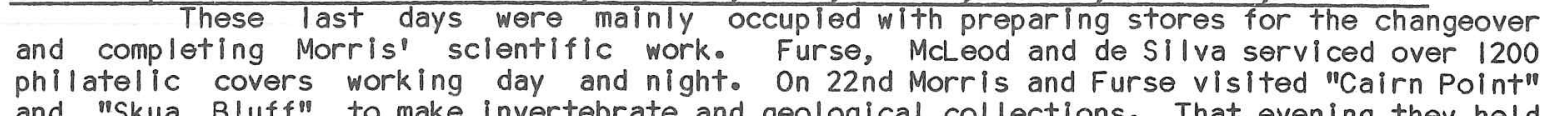
and "Skua Bluff" to make invertebrate and geological col lections. That evening they held the long-delayed mid-expedition Christmas feast, drawing numbers to open presents from
Carole de silva, and telling the Astrolabe Party over the radio about the goodies they were missing.

$\frac{\text { Team Changeover. } 24 \text { March, } 1984^{\circ}}{\text { Radlo contact with HMS }}$

Early on 24th Endurance then embarking started to "Astrolabe Point", landing food and fuel near the campsite, The the 3-man party.

Dover and wrecked the Post office tent, (another rapidly. Over 50 loads of food and fuel and general stores (including the Triwall Hut) members Join Hankinson and Trathen. Furse flew onboard briefly to thank Captain Colin McGregor ask Lt Cdr Andrew scott (the First say farewell to the seven departing First Summer team, and Then Lt Dave Issitt flew past the basecamp waving a year's farewells, and 

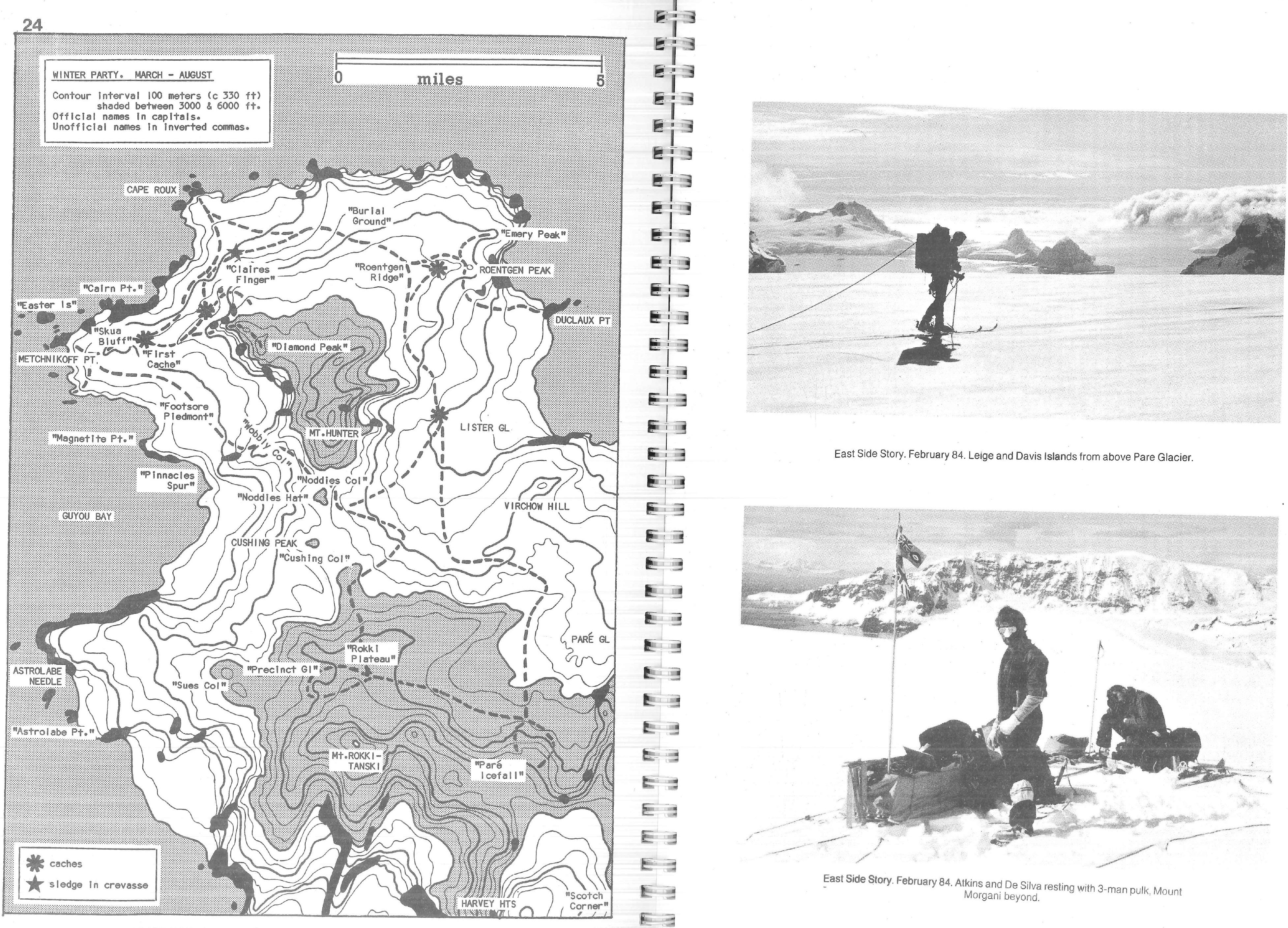

East Side Story. February 84. Atkins and De Silva resting with 3-man pulk Mount 


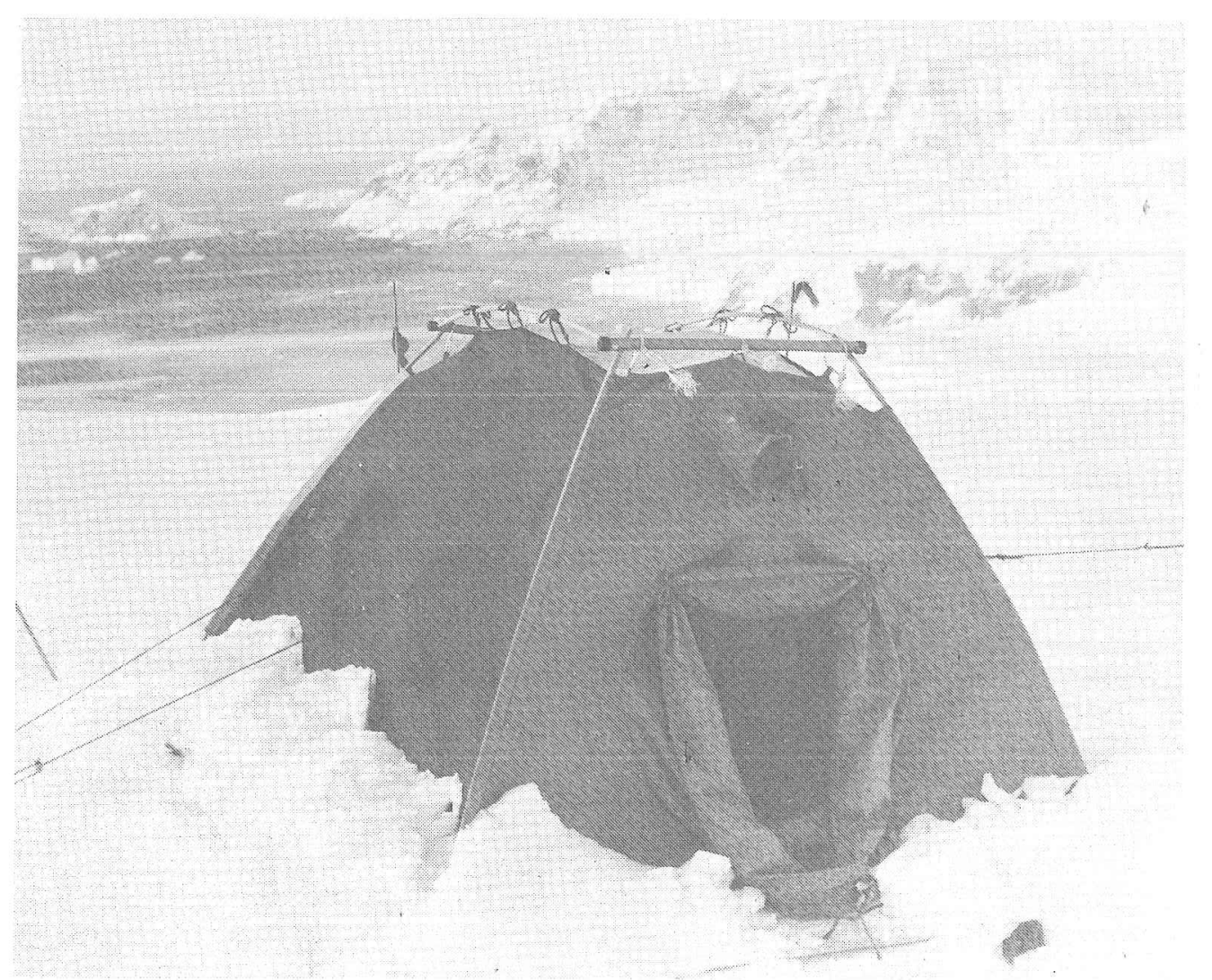

Conquest snowline box tent on Lister Glacier. Mount Morgagni beyond.

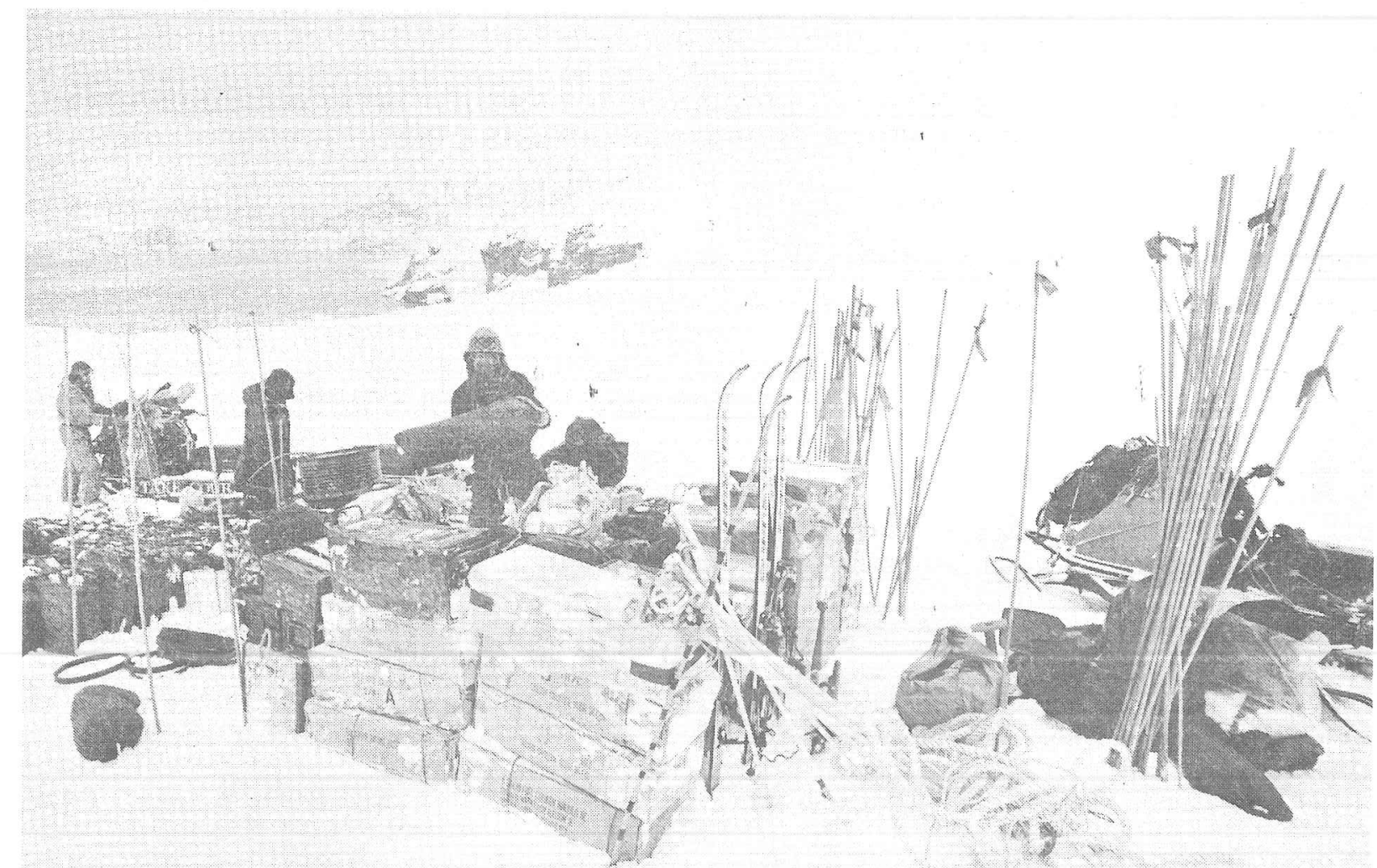

Skidoo party. Spottiswood, Aikins and Beattie on Lister Glacier with some of the mountain of gear they moved in September.
Basecamp. 25 March - 8 April 1984. Whole Team

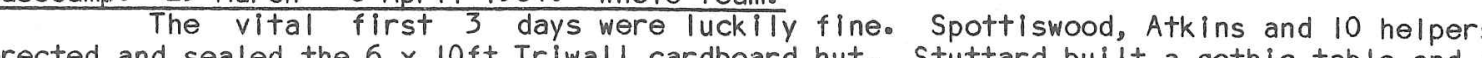
$5 \times 6 \mathrm{ft}$ porch/workshop from pallet timbers and plycases. Kimbrey led a complete drifting) instead of a zariba (against penguins). On 27th the first of many team gathainst was celebrated in the little hut, or shed. The weather then deterlorated, with much low cloud, rain and wet snow, and some
gales. Movement was restricted to short famillarlsation day-trips skiling roped-up on the
piedmont behind and visiting the points just to southwarde on 2 nd 3 rd Apr Lumsden \& stuttard visited "ip Innacles Spur", sorting out one cache left there in February, although the other smaller one had disappeared.

strengthened the hut with wooden skis and was accomplished around basecamp. Atkins also Spottiswood who started regular repairs of the Nova dome tents and various vital equipment. Routine recording was continued on Meteorology, Seals, Birds and the Tídegauge and Ringe and Beattie settied down on their Geology and Tes restr. Furse setting fire to one dome tent, another tent pole breaking in a gale, and the Tidegauge being damaged a fourth time in a stormo

The weight loss was 13 lbs, 9\% of U.K. weights, maximum 43 lbs lost by Furse). On 7 th the first victim was wired up with 9 temperature sensors and the 24 hour chart recorder for Coth Atkins started

Saccone and Speed, Altogether the Winter Party had made an excellent start, individually and and generaly and general paperwork, equipment repairs, phys lology rigging and unrigging, and as a dental
surgery. On 9 th an 8 man party left for Duclaux Point. $\frac{\text { Basecamp Party. 9-18 April 1985. Oakley, Atkins, KImbrey, Lumsden. }}{\text { Kimbrey's blisters (incurred visiting in Innacles Spur" on }}$

olsoning and fever. The party therefore remained at Metchnikoff Pod/3rd) led to blood there. Oak ley progressed his physlological research, with all four undergoing Cold Stimulus build a superb $12 \times 8 \mathrm{ft}$ bombproof skidoo garage/workshop out of plycases, scaffolding wooden skis and Triwall boxes, taking 5 days and nights. The Union Garage would provide worage, work ing space, the plus the library etc. On the evening of 18 th, Beattle, Corbett and de Gerlache returned to base with a story to tell.

Duclaux Point Party. 9-17 April 1984. Furse, Beattle, Corbett, Evans, de Gerlache, Ringe, Furse planned a 5-day trip for the Winter Party to experlence pulking, and
general travelling conditions: the alm was to reach and explore Duclaux Point and if possible some other north coast areas, concentrating on geology on 7 th two pulks were hauled to "First Cache" in high winds. In better weather on 9th the party traversed east rom "First Cache", camping in a crevasse halfway to "Claires Finger", then two nights
holed up in a blow under Roentgen ridge. A stable depresslon of 957 mbar allowed them to reach $2000 \mathrm{ft}$ on 12 th, camping in a huge snow-filled crevasse and meeting the first low temperature problems with dome tent poles. Next day, after several hours in whiteout they camped just under Roentgen Peak. The 14 th was superb: the party skied down to Duclaux
Point but lack of time allowed only the briefest geological reconnalssance, getting hal fway down the icefall to the northshore, before returning and ascending Roentgen Peak Just $80 \mathrm{ft}$ above the tents. Puik travel was much slower now due to the shortening days (sunr ise 0820, sunset two days rations left, prudence dictated returning toward base. On 15 th they pulked 9 mi les to Cape Roux Easto En route SpottI swood and Evans detached to make the First Ascent
of "Emery Peak" on skis. Having started with 4 Nova tents plus a set of spare poles, they of "Emery Peak" on skis. Having started with 4 Nova tents plus a set of spare poles, they
were now reduced to 2 sets of poles plus some pleces, due to breakage etcoand one set sliding over an icecliff at Cape Roux.

nable to walk due to a severely bruised and inflamed wy a from Cape Roux Westo. Ringe was unable to walk due to a severely brulsed and inflamed "Val luga ank le" from the return pulk
journey. Therefore Furse and Stuttard stayed with him (with $3 \times 2$ mandays rations) while the other five with both pulks and Just 2 mandays ratlons returned to basecamp to fetch
more food. They left early on 17 th with Spottiswood leading. 
Cape Roux to Metchnikoff Point. 17-24 April 1984. All Team Members.

pulk fell 40 ft into a completely unsuspected crevasse, de Gerlache was dragged to lle

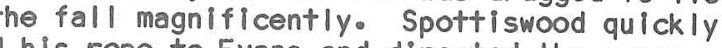
Evans, unhurt, managed to free himself from the pulk and then jumared up to to the rescue. hours. Their one tent was down the crevasse, and de Gerlache was shocked and rapld ly
developing exposure, so Spottiswood and Beatrie swiftly ( I $\frac{1}{2}$ hours) dug a 5 man snowhole in
the nearby drifted crevasse. All five gratefully crowded in for the night. Only Spottiswood and Beattie were exper lenced mountal ineers. Evan's skis were
down the crevasse below the pulk. So on $18+\mathrm{h}$ Beattile, Corbett and de Gerl ache somewhere down the crevasse below the pulk. So on 18 th Beattle, Corbett and de Gerlache
sked through a snowstorm to basecamp to fetch help, taking the rope, and leaving they could not, Beattie and Kimbrey prepared the skidoos that nighto However next day, of food out, arriving at the snowhole at 1600 , to a hungry welcome. That evening Atkins Next morning (20th) Atkins went down again to recover Evan's skis from about $80 \mathrm{ft}$ met Furse \& stuttard returning to get more food, surprised Ro "The others are up at the snowhole. There's been quite an eplc up there". Furse and Stuttard then Joined Spottiswood, Evans and Lumsden taking the two pulks on to basecamp.
On 2Ist despite a NE gale and spindrift, Kimbrey, Spottiswood \& Stuttard tried repeatedly to drive the skidoos out of base, but the powder snow on ice prevented them. Helped by the other 6 they spent the whole of 22 nd fighting two skidoos, one steel slemge
and a pulk up over the skyling, where they were cached at $600 \mathrm{ft}$, with a glorious blue and On 23rd Kimbrey, Oakley, Spottiswood and Stuttard left on 2 skidoos with the loaded $8 \mathrm{ft}$ sledge. Above the difficult descent to: "Claires Finger" they cached the sledge:
Kimbrey and Stuttard took the skidoos on to reach Cape Roux at 1300 . Ringes ankle had turned septic, but was beginning to recover. He rode pllllion as they headed back: after

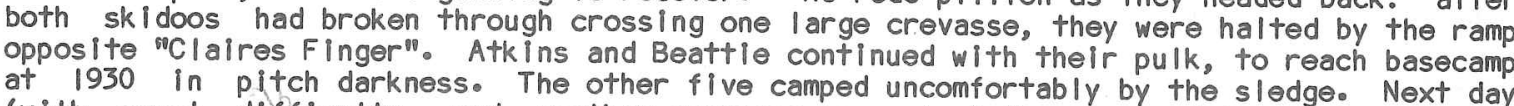
(With great difficulty, and another crevasse near-mlss) they managed to get the skidoos Everyone was now safe, and back at basecamp.

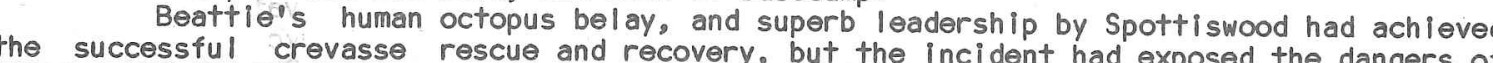
small parties with several inexper lenced mountaineers. Rules on the composition of partles were tightened up, at the expense of reducing the team's flexibility and mobility. Atk ins,
Furse, Kimbrey, Spottiswood and Stuttard were categorised as Leaders; Beattie, Corbett and oak ley as Seconds, and Evans, de Ger lache, Lumsden and RInge as Beginners. Minimum party size was raised from 3 to 4 for anything more than local journeys, with limits on the

The dangers of 3 or 4-man pulking were recognised, and 1- or 2-man pulking now became the aimo. The first skidoo journey had also exposed their limitations on steep
slopes and in powder, the difficulties of towing loads, and the compromises between safety and ease of operation. The honeymoon with the skidoos was over. Much Basecamp. 25 April-10 May 1984. Whole Team. The alm was nowi to get a strong 6-man party away with the 3 skidoos, sorting out
load-hauling techniques, and putting a cache on Lister Glacier for winter work. As the poor weather continued, with much snow in early May, it became clear that this trip would Heights, and a light party cortin Kimbrey, Spottiswood and Stuttard worked very hard preparing skidoo-train equipment, and
continually trying to get up the soft nnow on the 22 degrees traverse slope to the skyline
above basecamp, (this was a major initial hurdle for every skidoo journey). On 26 th Oakley's second physiological Flurd Balance day showed all team members
reacting normally to the cold by diuresis, dehydrating the blood (in 3 weeks the team's mean percentage of red corpuscles had risen from 43 to 48 , and so resulting in greater recordings was also completed. The first full round of 24 hour "Cold Stimulus" temperature Other scientific work was progressed. Evans completed his initial survey of the
beach (but the tidegauge became unusable due to freezing). Beattie found some undescribed 900 to 80 , and lon 27 th the Chinstrap Penguins left, but there was seals had dill will wiled from de Gerlache and Furse, while Ringe worked on local geology. Meanwhile Corbett continued Lumsden took over the radio, as well as routine met. readings. He arranged with
Palmer Station to pass some 250 word messages home. He also made contact once with Statlon

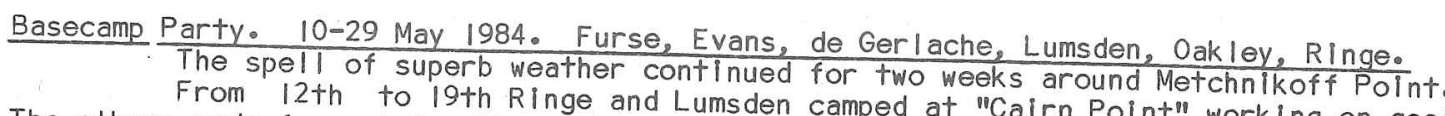

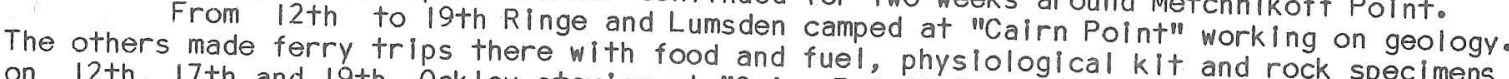

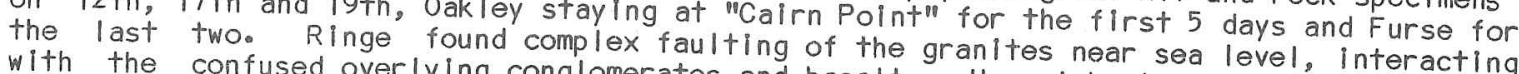

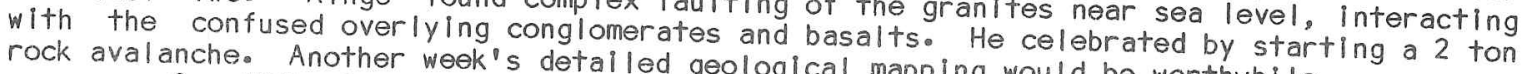

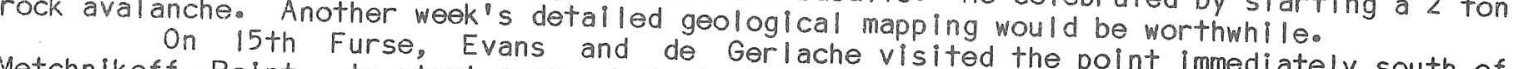

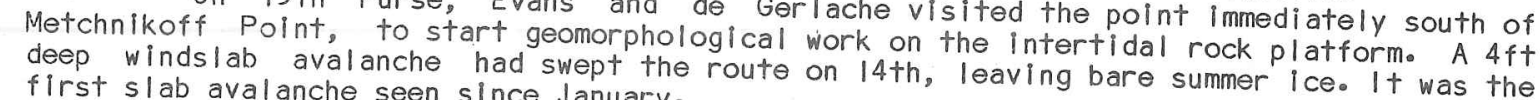

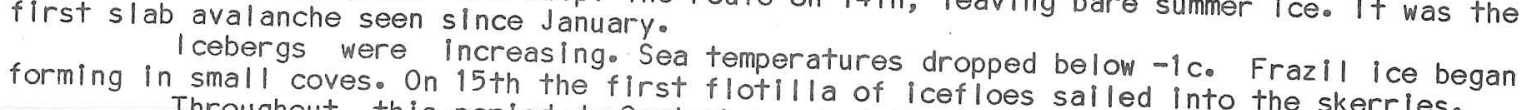

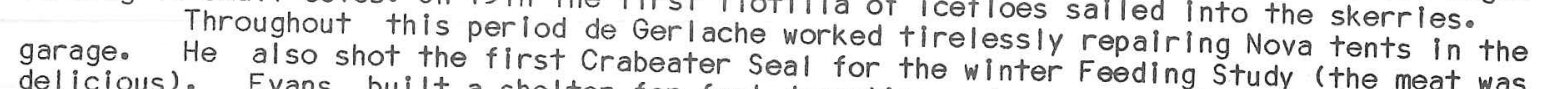
continued physiologlcal research work, and began measurements of thermal heads. Oak ley clothing and tentso (He conflrmed that the hut was much colder than tents). conditlons in

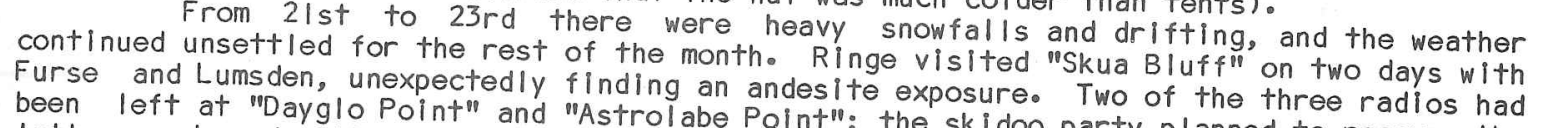

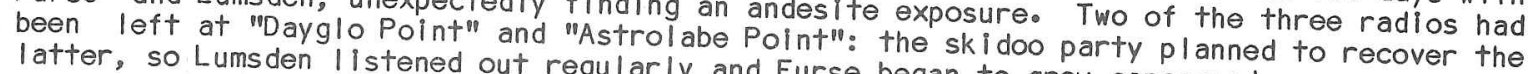

on the afternoon of $29+h, k$ K Imbrey, Atk Ins and Stuttard sk Ied Into basecamp.
on

Lister Glacier Skidoo Party. 10-29 May 1984. KImbrev, Atkins, Beattie, Corbett, Spottiswood

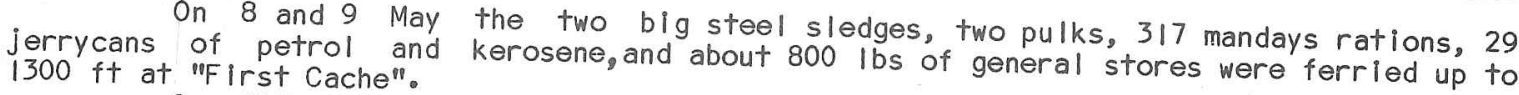
On loth the party left Metchnikoff Point with the three ski doos. Drifts made
travel difficult, and once Spottlswood's skidoo (in the middde) was rollod the turns as the ropes tautened on an aukward traverse. However they reached thee complete

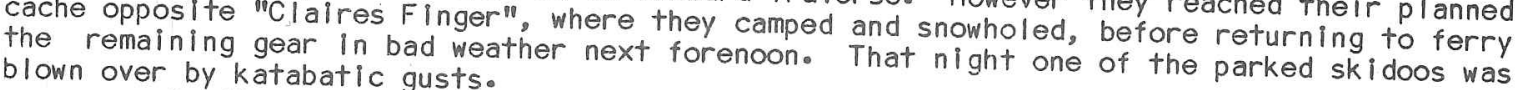
blown over by katabatic gusts.

put a cache up on Roentgen ridge, caming Stuttard with the 3 sk Idoos and one steel sledge

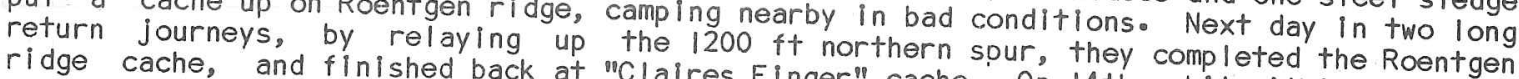

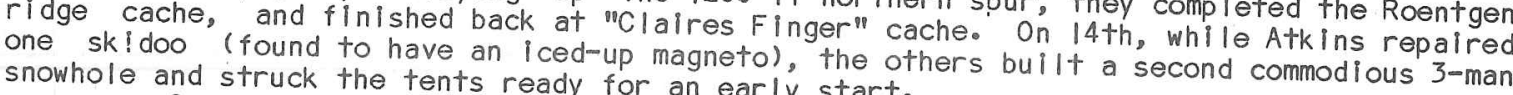

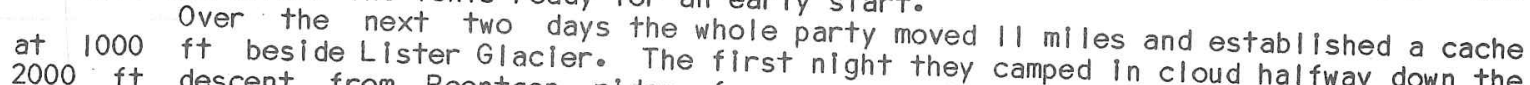

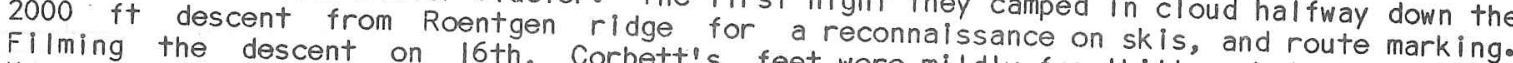
KImbrey's stomache On 17 th Corbett recuperated in Camp it thy frostbitten, but recovered on

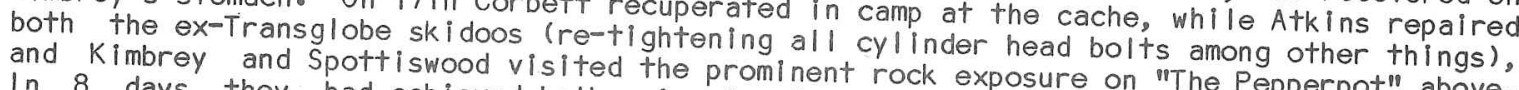

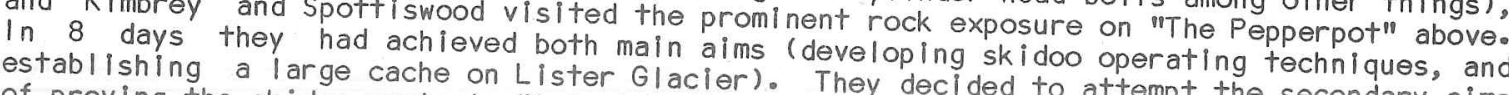
of proving the ski doo route to "Astrolabe Polnt".

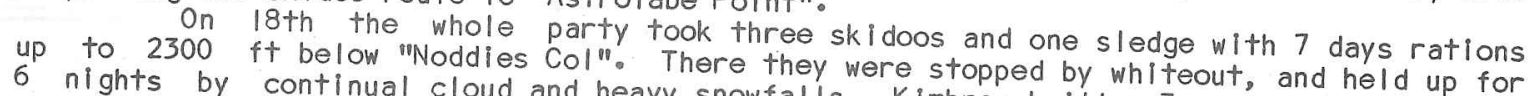

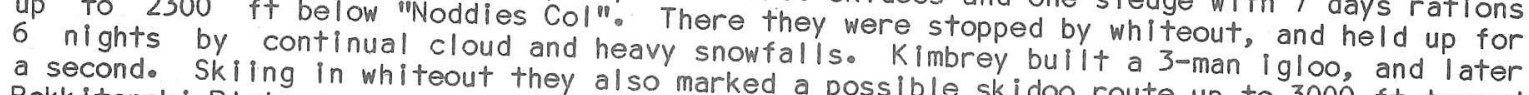

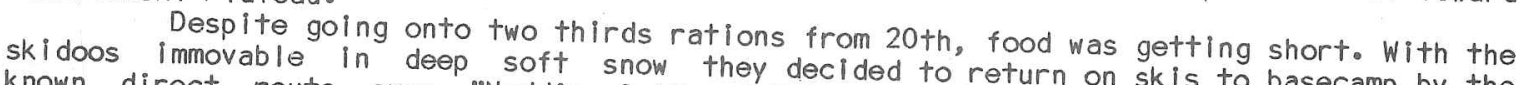

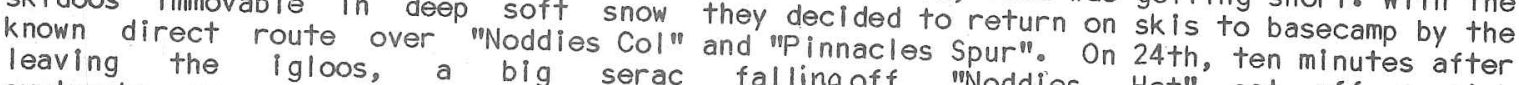

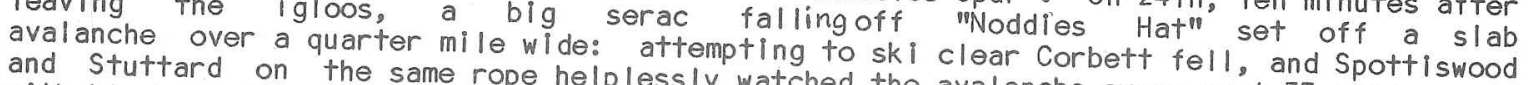
and Stuttard on the same rope help lessly watched the aval anche sweeep past 35 yarts away.
wilth blocks ending up with

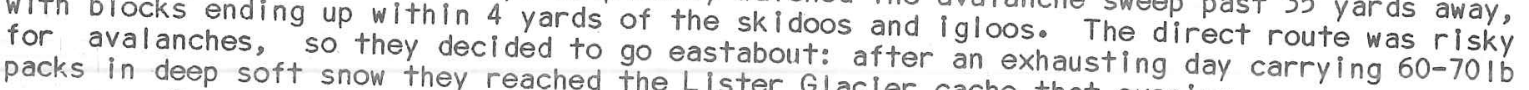

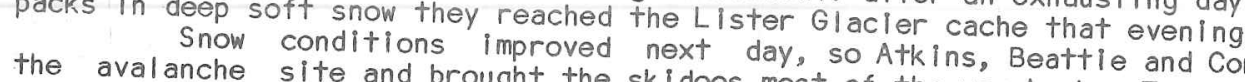
the avalanche site and brought the skidoos most of the way back a d Corbett returned to

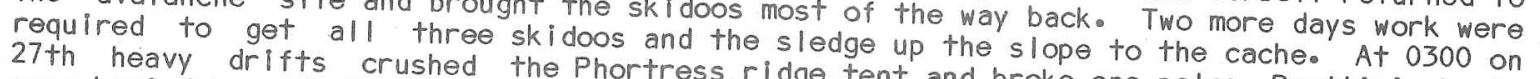

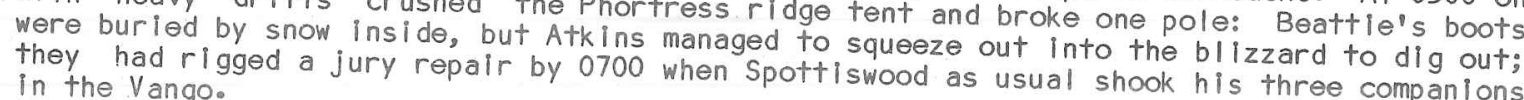


On 28 th they made a remarkable 11 mile journey in dense cloud, climbing and

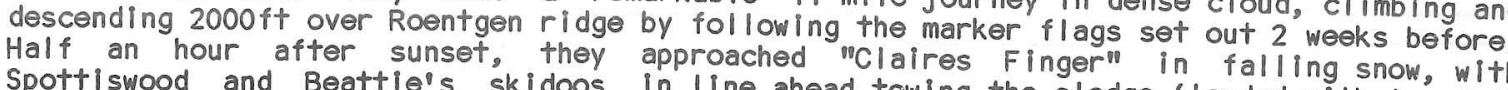

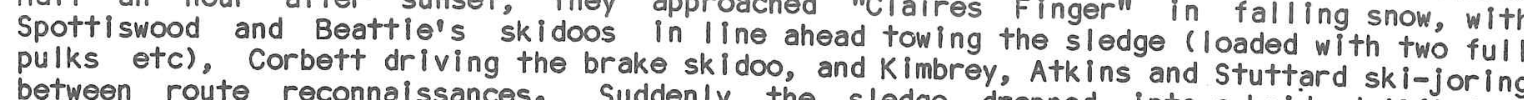

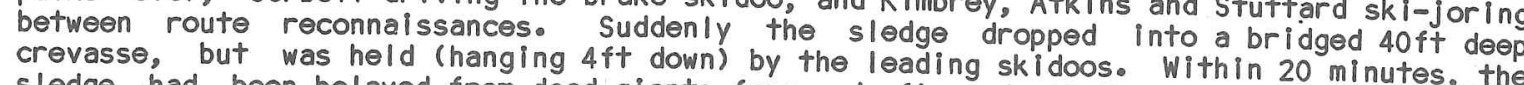

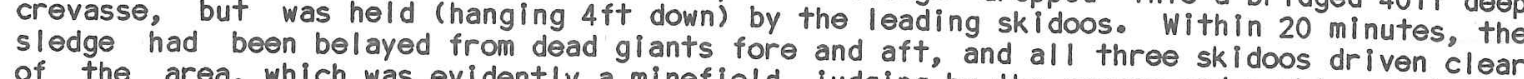

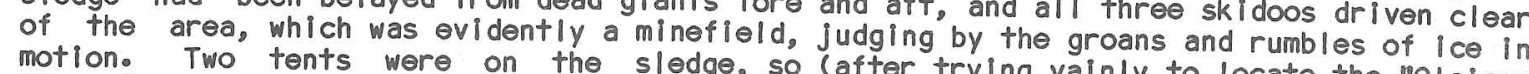

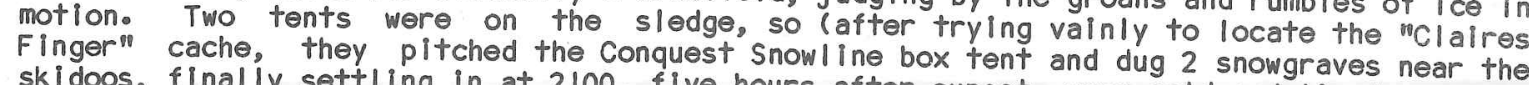
skidoos, finaliy settling in at 2100 , flve hours after sunset, very cold and tired bowl conce more in ing after early wind and snow, they brought the 3 skidoos around the

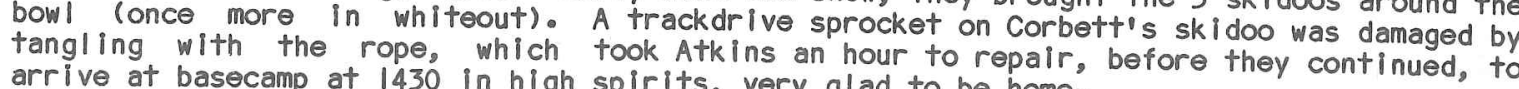
They had successfully lystablished 21 mandays caches for later exploration around
Bouquet Bay and worked out the bost way of using the skidoos in unusually difficult
terraln nasty crevasse conditlons. Although granted superb, often in deep and soft snow, with

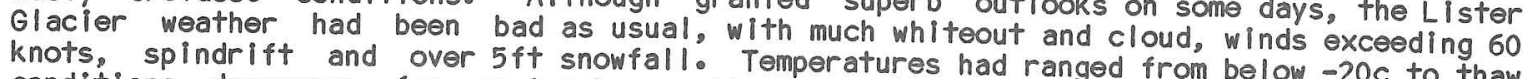

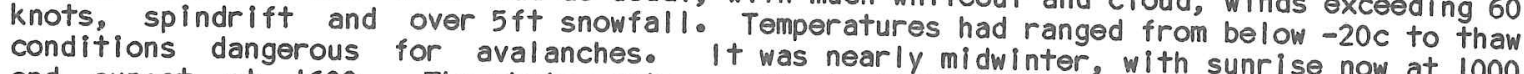
and sunset at 1500.0
be proud of themselves. The whole party, particularly KImbrey as leader, had Just cause to Basecamp Area, 29 May - 5 August 1984. Whole teame

was now thoor weather prevented an Immedlate reteturn to recover the loaded sledge, which

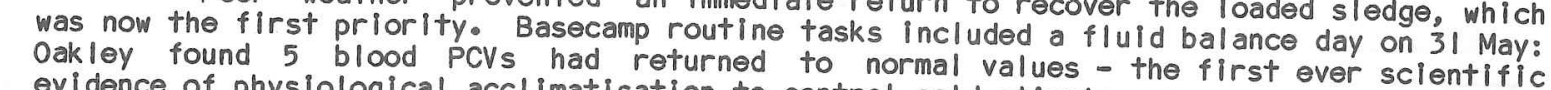
The weather Improved on 2 june. Next day a sld stomulus.

\& Spottiswood) and a pulk party (Furse, de Gerl ache, Lumsden) went to they, "Beattle, Ringe cache, digging 3 new snowholess. For 3 days wind, snow and low cloud prevented skidoo travel, collected rock samples from "Claires FInger". Rations were "limited

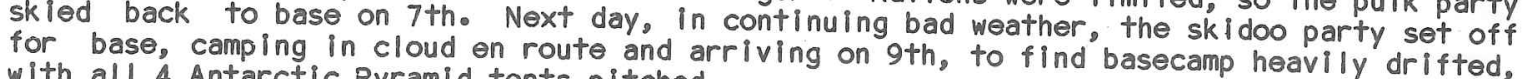
The third skidoo was out of action while Atkins Improvised repalrs to a rear trackshaft, strengthening the damaged bear ing hous Ing, bul I ding up the scored shaft Journal

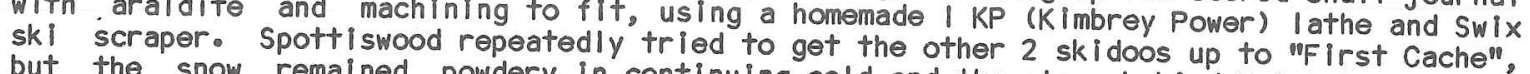
but the snow remal ned powdery in cont inulng cold and the slope behind Metchnikoff Point

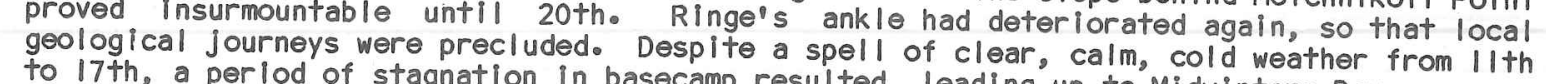
(sunrise The sciences weres all progressed steadily, but much of the short dayl I ght

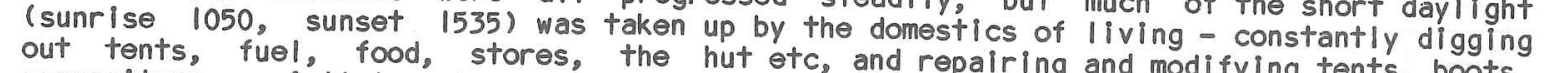

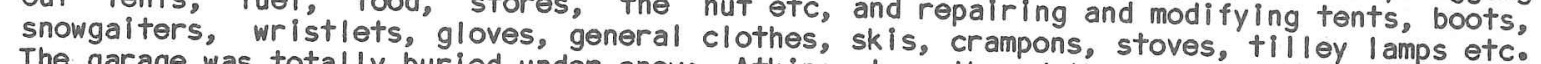

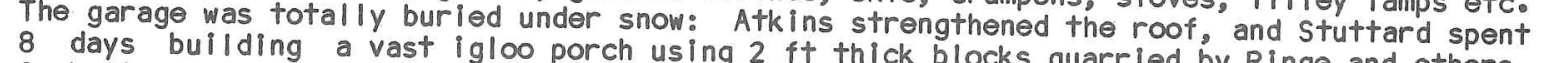
corbett progressed still and cine work with total dedicatlon, concentrating on adverthisho

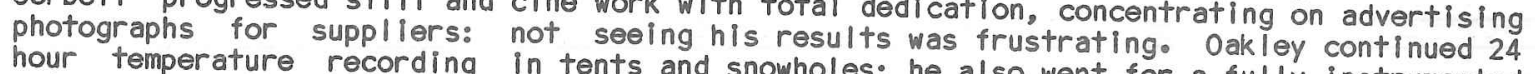
hour temperature recording in tents and snowholes; he also went for a fully instrumented

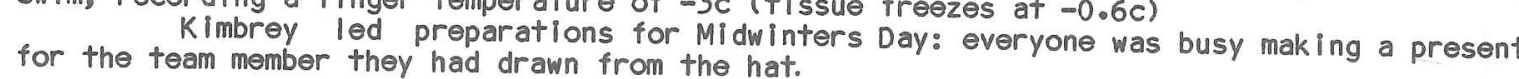

Midwinters Day, 21 June, dawned glorlously calm and sunny. After breakfast oakley
swam among brashice for 20 minutes wearl ous

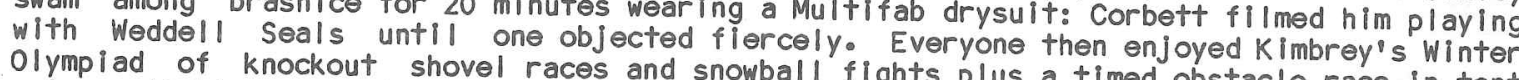
Olympiad of knockout shovel races and snowball fights plus a timed obstacle race in tent
pairs, (cokkley won, fron Ringe and Lumsden) (soup, kavlar, pll charrd cake, chicken, crabaater steak, frult duff se di inner began in the het plus sausage rolls etco We were dis sappointed to be omittred from the Falk lands broodcast to BAS). The opening of team presents revalage narvellous

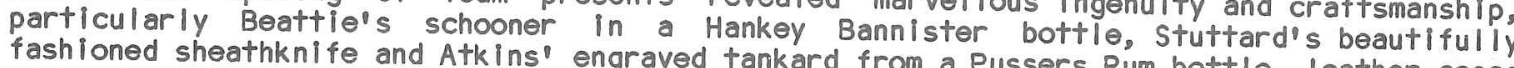

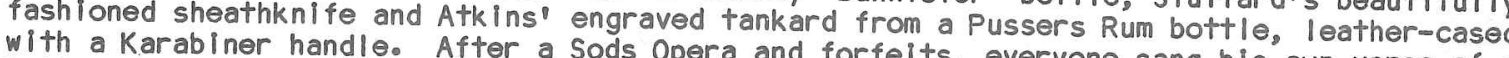
ball ad written by oak loy. The last four went back to their tents at 0700 , four hours before
the first earlller sure ise.

food and Next day Spottiswood and Stuttard got the skidoos up the backslope and ferrled

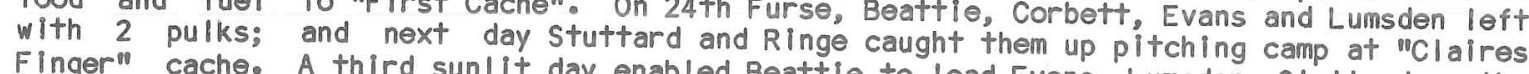

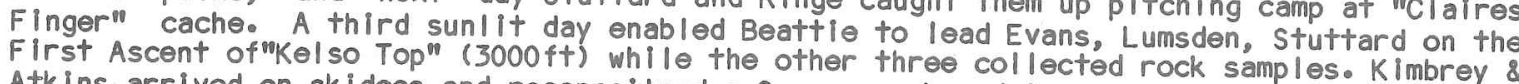
Atkins arrived on skidoos and reconnoltred a severe rock and lice cl Imb up "claires FIngern"

:

E

E

E.

E

E

E]

E

E

E]

E $]$

E i]

E

E

$E$

E 面

E 프

E IiII

E

E iii

E ii

E IIII

E

E

E

E iin

5 iii

$E=$

$E=$

$E=$

$E=$

$E=$

$E=$

$E \equiv$

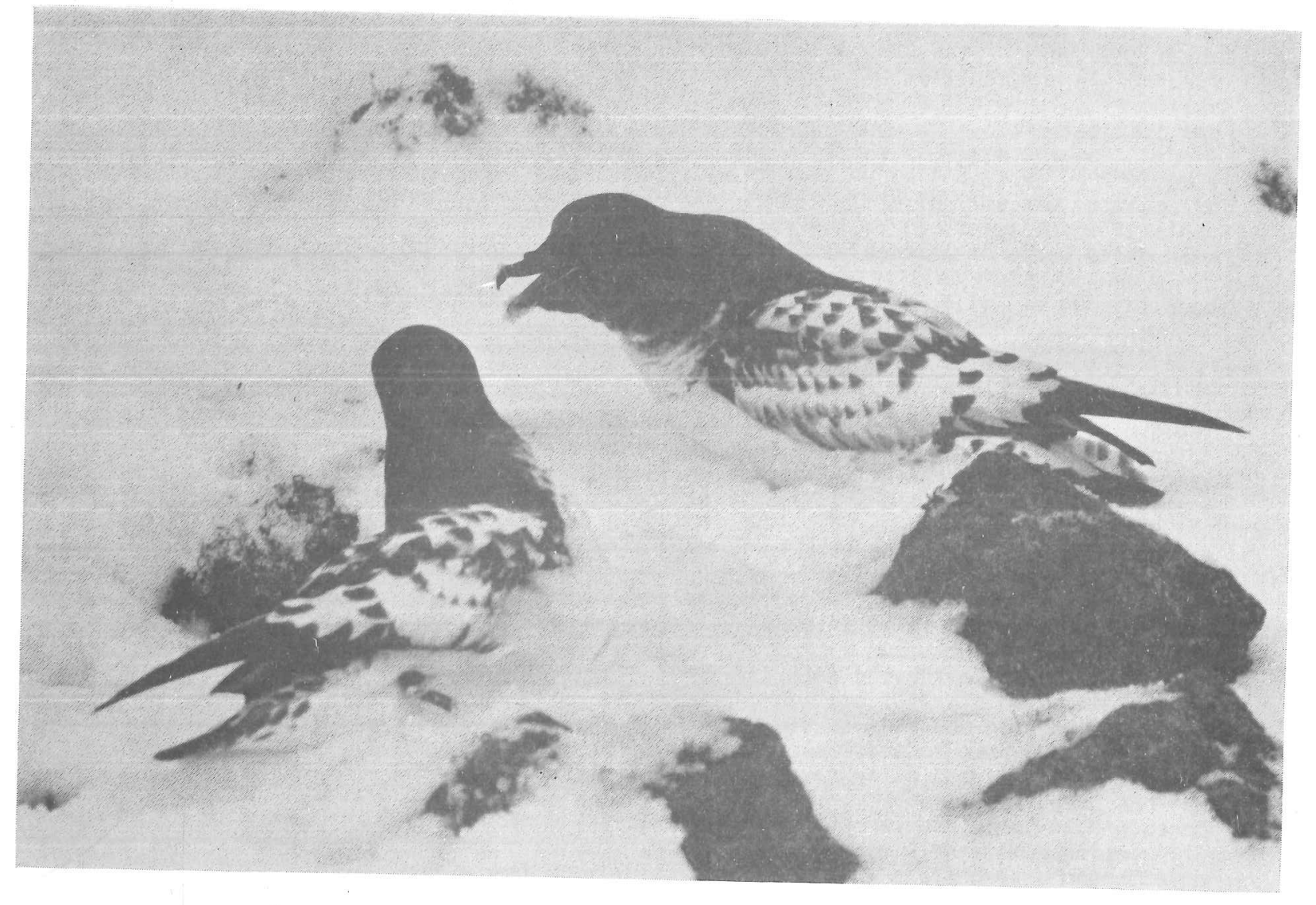

Cape pigeons at nest site in June.

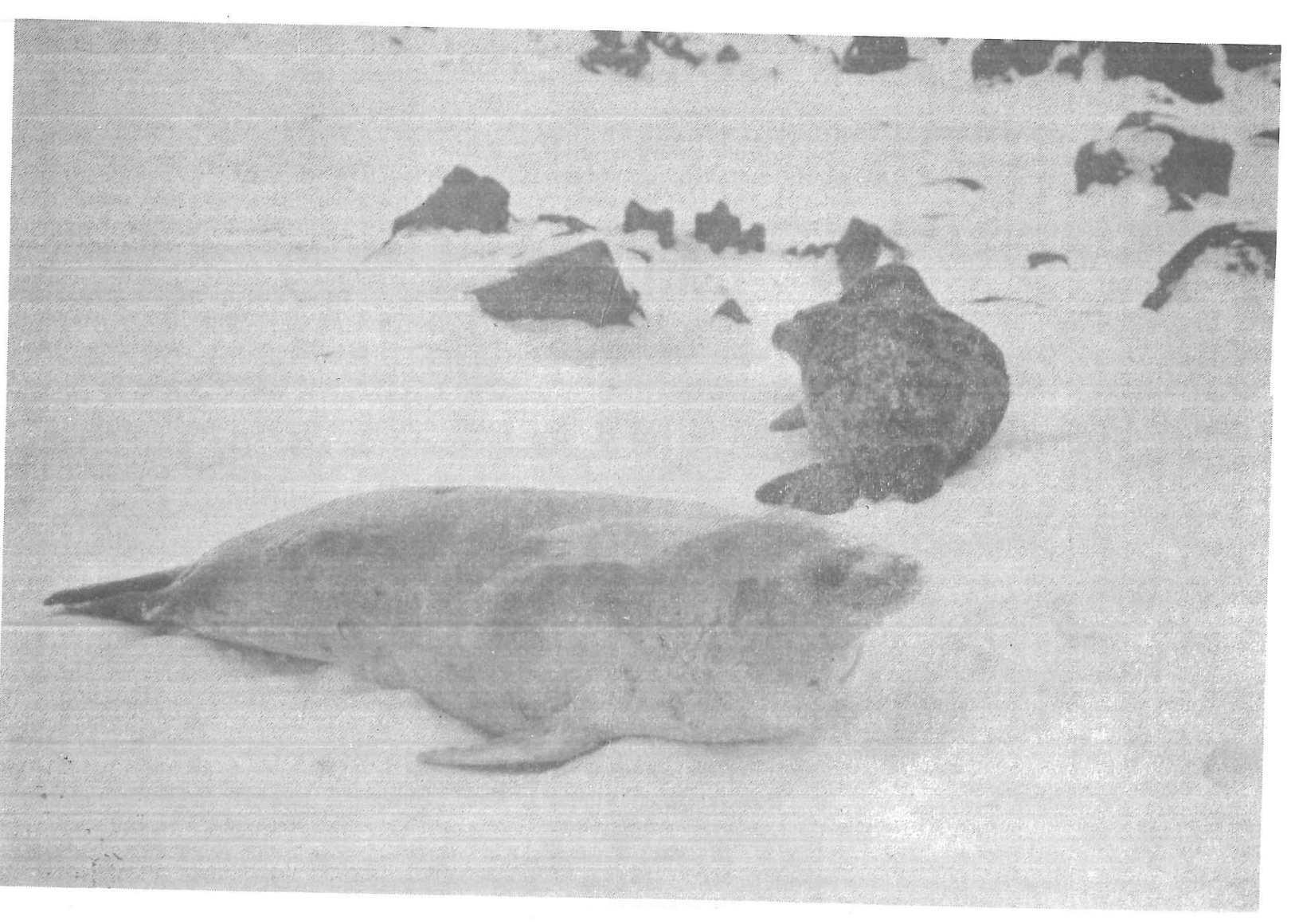

A Crabeater seal comes ashore in June (Weddell beyond). 


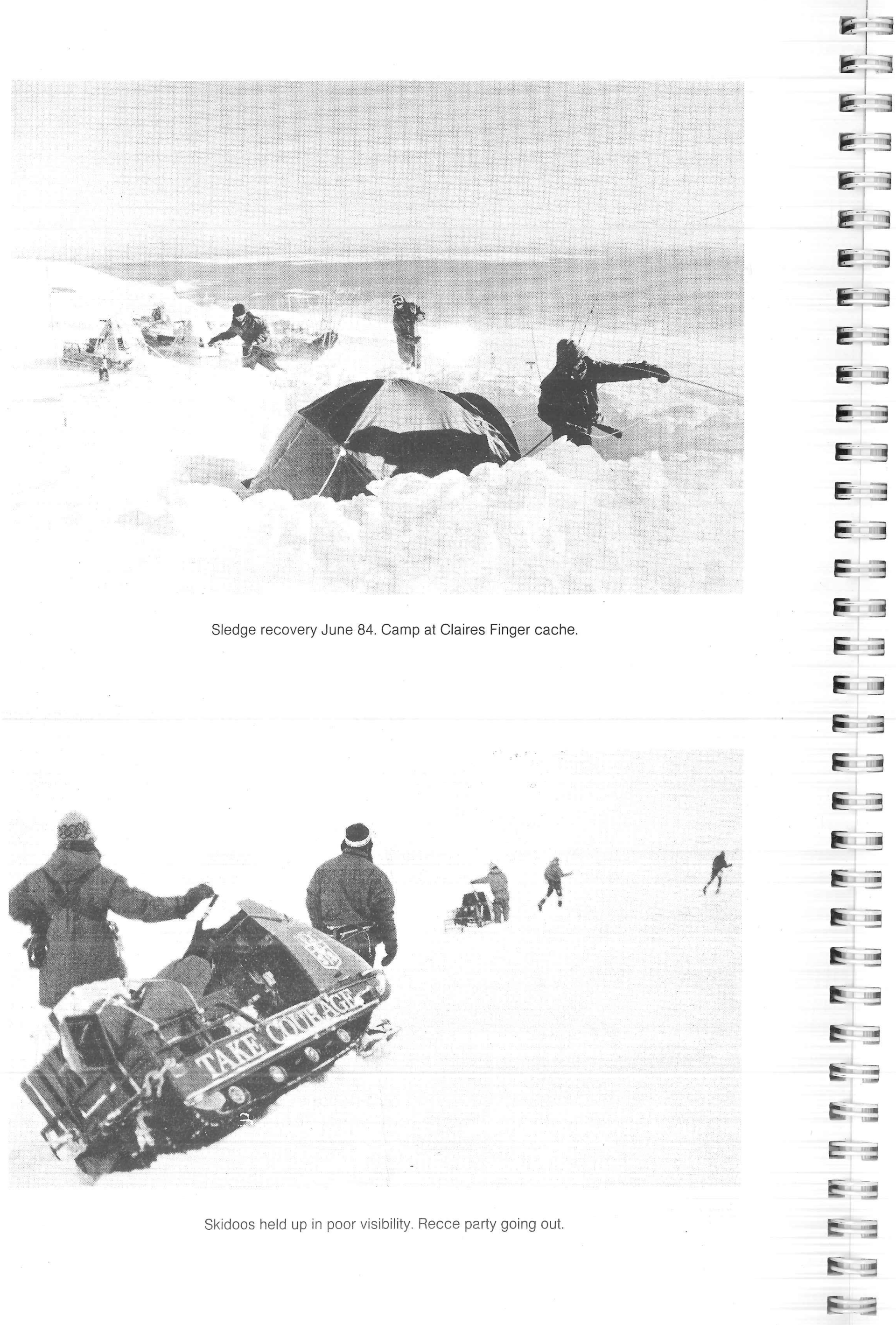

After one day's bad weather fester, Kimbrey, Atk ins, Beattle and Stuttard took advantage of crevasse. It had fallen further and been buried with one end Just showing $20 \mathrm{ft}$ do the successful recovery was a great team effort and a great rellef after a month. Corbet from above "Claires Finger". On 30 th a planned film sequence of a crevassee famples rescue was prevented by rising wind, and premature collapse of the crevasse bridge (Corbet becoming the 4 th member of the Head-Under Club, with Atkins, Furse and Evans). Kimbrey Metchnikoff Pointo 32 inches of snow falling that night burled the tents and rew uclaires Finger", and on I July the other five cached the 3 pulks and skled back to base, using some peculiar ropes.

mountaineering sas confirmed as Leader, having brought his skiing up to his general good Our top priority now was preparations for the move southward in September.
Spottiswood, with Ringe and Lumsden, used a spell of good weather and snow to ferry food,

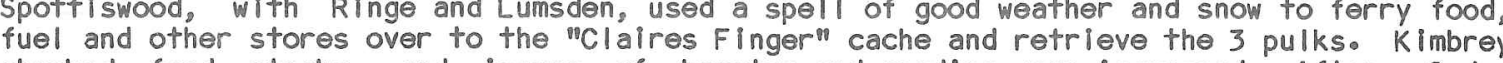
checked food stocks, and issues of booster and goodies were increased. After a 2 day search for buried barrels, Evans revealed that gasolene was short for the journey south: after much discussion, estimation and calcul at in, stores or the Journey were severely
pruned. A revised plan evolved, with 6 men golng right south, and 6 completing the northern exploration from "Astrolabe Point"。 Colder, calm, clear weather in the first week of July brought swathes of pancake
ice into the coastal bays and by 8th there were many bergy bits and old small floes On 7th Furse, Ringe and Spottiswood skied to "Cairn Point" to camp for a weeks detail led geological survey, Relays of porters (Kimbrey \& Lumsden on 8 th, Atkins and
Corbett on loth, KImbrey, de Gerlache and Stuttard on 12th) brought over fuel and Compo rations and returned with rock samples. Evans came over on 10 th (to establish ground control, hoping for aer lal photography by Endurance) and Spottl swood returned to base. That night, under a full moon, a big westerly blew up. Gusts of over 100 knots were skidoos. The four exposed Antarctic Pyramids and one conquest Snowline at base, and the sheltered Super Nova at "Cairn Pointll all survived, but the Maureen Dome, strengthened Jell Iraven pyramid and (old) Gresshoppe pyramid were all blown down with broken poles. Point" snowlides all round the butte at Metchnikoff Point and a slab avalanche at Sku Bluff. On Friday $13^{\text {th }}$ three small tent fires occurred due to petrol contamination of parafin for stoves: Furse ordered a formal enquiry, which identlfied the source as a big westerly blew up, tearing up the lcy crust and flinging it at the tents. coakley aptly likened sitting in a tent to sitting inside a kettledrum under shotgun fire). Lumsden recorded diging out their tent, and ceparect. Spott swood and de Gerlache spent half the

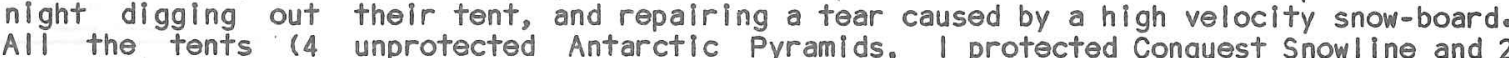
protected Super Novas) survived gusts estimated over 100 knots. Next day Furse, Evans and up the ridge up the ridge. sea ice had almost all disappeared, but more icebergs were now aboute Changeable gusty weather continued. Deep powder, ice crust, heavy snow and more powder
made movement difficult, and dangerous, preventing all but short ski trips to "First Cache"

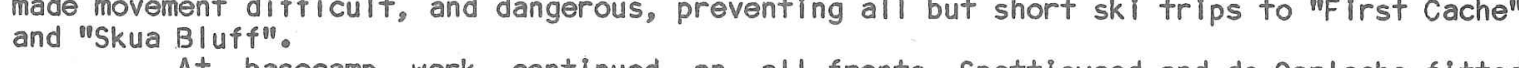
At basecamp work continued on all fronts. Spottiswood and de Gerlache fitted
storm guys to Super Nova tents and repalred poles. After another fluid balance day on 20 th oakley found that everyone had now acclimatised to cold, with blood PCVs returned to managed to send $250-$ word first message received since 25 May), we learnt that the Second Summer Party would arrive late December, now enough food in the north (including that at "Astrolabe"), to last us until 25 November, thanks to the extra Kimpo and Kimpack made up by Kimbrey earl ler from booster \& goodies. We The weather continued very unsettled for the rest of July, with high winds cloud and occasional fine days. Temperatures varled, with a difficult mixture of deep soft snow, a hard crust, and sometimes wet heavy snow. Much sea ice arrived, but then blew away a gastoned to late August, to fit in with other planned pulk journeys. preparations, then Journey south continued, and Spottiswood managed to ferry more petrol and stores to "rFIrst Cachen ${ }^{n}$ on two days. A radio message from BAS expressed great interest in the large miteike creatures found by Beattie earlier. Photography and sciences were progressed, with

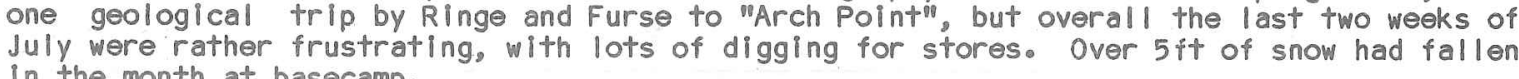
in the month a basecamp
August began with a northeasterly blizzard and a massive depression reaching 936 mbars next day, which was calm, but with a heavy fall of snow. On 3 rd Beattle collected more of the monster mites, Including one $7 \mathrm{~mm}$ long. A spell of superb weather began in the
afternoon of 4 th, when Spottiswood ferried more gear to "WFirst Cache", reporting a foot of afternoon of 4th, when Spottiswood ferried more gear to "First Cache", , reporting a foot of
Angels, Dust snow on crust. Next morning Atkins took a 4-man party with 3 pulks away to 6000 tt. It was the first move of the Spring journeys. 

Winter ascent of the NW ridge of Mount Hunter, reaching "Diamond Peak" on 7 th they Finger" in crampons (grading the vertical one pitch rock route Severe). After 3 days superb weather, there was $7 / 10$ packice from the shore to the horizon on 8the Furse, de Gerlache \& stuttard collected rock samples from above
increasing snowfall, foll lowed shortly by Kimbrey's part.

After an overnight blow most of the pack had gone on 9 th.

Routine basecamp work continued in unsettled weather. With inexhaustible energy spottlswood prepared and ferrled gear for the skidoo journey south. Corbett winter serles of 24 hour cold stimulus records. On 13 th we learnt from Faraday that our last 9 weekly bulletins had been incorrectly sent from BAS Cambridge to the Falklands (8)

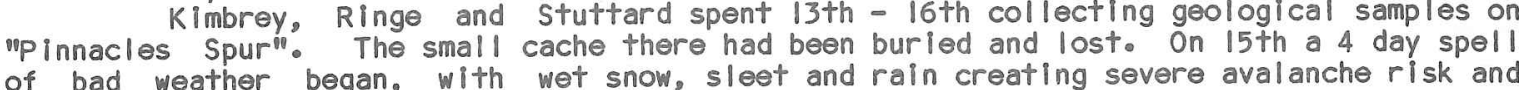
dangerous crevasse conditions. She snowclifts outside and Kimbrey caught our first fish ( 10 Antarctic Cod) ledgering from We heard from Dr Block (BAS Cambridge) that the "Metchnikoff Monster Mites" collected by Beattie and described by oakley were probably a significant new Antarctic
species, of the obscure family opil ioacaridae, known only from Australasia and tropical Indian Ocean islands. We also learnt from our rear I ink that RAF Movements had lost all the First Summer botanical and invertebrate samples. on 23 rd, in glorlous wather, two Humpbacked
skyline.

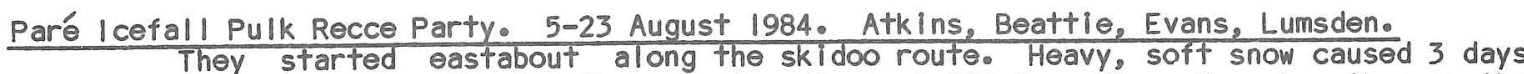

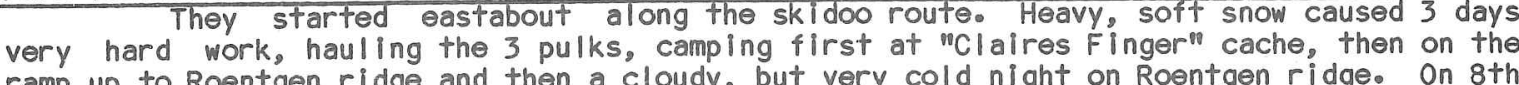
ramp up to Roentgen ridge and then a cloudy, but very cold night on Roentgen
they dropped down to Lister Glacier, camping after missing the cache in cloud.

During breakfast next day Atkins emerged. Ten peet outsider his morning constlutlonal he broke through a crevasse brldge. Very luckily he landed on Atkins and Evans found the cache (2ft of the upended sledge marker stilli showing after nearly 3 months), dug it out, and re-erected the sledge marker,
The next three days were all very cold, with continuous cloud. They moved four miles up Lister Glacler, then 2 miles toward Virchow ridge, then another 2 miles onto the ridge. On 13 th in better weather, they reached the pledmont below Pare Icefall, camping at 3500 fto Despite sleeping with their legs in paper sacks, and rucksacks pulled over their on 14 th all four reconnoitred three possible skidoo routes up the NW side of the icefall, but with 40-60 degree slopes none were real ly practical on 15 th, while Beattie
and Lumsden dug out and repitched both tents, Atkins and Evans found a route up the SE side where it might be possible for skidoos, with winching from 4,100 to $5000 \mathrm{ft}$.

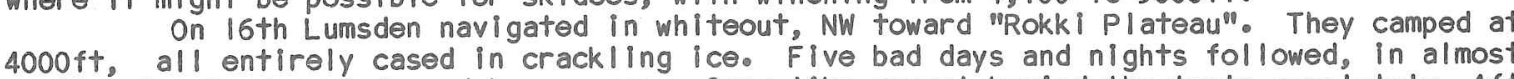
continual cloud, wind, and heavy snow. Snow like gravel burled the tents completely, $4 \mathrm{ft}$ the tent doors to the surface, and a rope was rigged between the two tents. Apart from some pole problems the Super Nova tents (with doubled heavy-duty poles, and 4 storm guys)
performed very well, but lack of ventilation and pricker defects caused problems with both performed very well, but lack of ventilation and pricker defects caused problems with both
stoves. On 19th they went onto half rations, with $4 \times 3$ mandays lefto On 20 th Atkins and Beattle seized a break to reconnoitre the planned skidoo traverse at $4000 \mathrm{ft}$ toward "Astrolabe point": this looked impassable for skidoos, but the top bowl of "precinct Glacier" might be better. They just beat the cloud back to camp. "mprecinct Glacier", keeplng open the option of restocking food and fuel at "Astrol abe Point" If conditions remained bad. However the 22 nd dawned clear and beautiful so the headed down to "cushing (attributed to co poisoning), but the party went on over "pi I nnacles Spur" onto "Footsore Pledmont". They camped in cloud at dusk Just 3 miles from basecamp, extremely dehydrated
after a hard 11 mile day. After a night interrupted by frequent noisy avalanches off Mount Hunter, they
returned to Metchnikoff Point in glorlous weather on $23 \mathrm{rd}$, Jubilant and rightly proud after 18 days meeting and overcoming, at $400 \mathrm{ft}$, the coldest conditions met so far. They had systems for partles with l-man and 2 -man pulks. had done very well on his first long trip and was made up to a second. (Note: Ringe was They were given a Sundays rest
been on the island for exactly 5 months.

premature dead Weddell pup was another, sadder symbol of approaching spring. on 25 th the whole team turned-to for a hard 7 hours digging. Ali stores boxes were secured for the Spring thaw. The remaining food was moved to surround the hut. The lost last 45 gallon kerosene drum was located and recovered from $12 \mathrm{ft}$ under the snow.
Westerly winds gusting to 100 knots blew on 26 th and 27 th. One Antarctic Pyrami suddenly blew away, exposing Evans and de Gerlache to the storm in the middle of their
breakfast (the tent was recovered from the beach undamaged; the snow had been blasted of the valence). Kimbrey and Furse were also blown out with broken Super Nova poles. and everyone busily completed preparations for departure. Beattio modifled a d a d six 30 th, for easier one-man pulking (harness lashings, rope brakes, and aft-end climbing rope clip). Furse, de Gerlache, Evans \& Ringe recovered rock specimens etc from "Cairn Point""
Only the roof of the hut was now showing above the snow, and a Triwall box tunnel was rigged, as the porch door was of ten completely drifted in 10 minutes.

for flue september came in like a lion. Westerly storms and wet snow delayed departure for five dayso The sea was $9 / 10$ covered with smashed ice on ist but it had almost all gone incorrect); soon afterward the "garage" ridge tent was wrecked by the wind. Finally the two Se soptonbor.

Skidoo Party. 6 September - 14 October 1984. Spottiswood, Atkins, Beattie.

cleared up and secured basecamp. Next day they ferried last items to " party (plus Ringe) kidoos burled tent they ferrled stores 4 miles east, establ ishing a cache at "The Burlal Ground"
below Roentgen ridge. Returning into wind 2 skidoos were blown over and empty pulks
capsized while airborne. Returning from their second "Burlal Ground" trip on 11 th, the Alpine 503 gearbox seized in engagement. They recovered it next day on the $12 \mathrm{ft}$ sledge. Atkins stripping it out at "Claires Finger" while the others made another ferry trip in increasing sleet and
cloud. Similar bad conditions prevalled on 13 th. Spottiswood and Beattle towed the $12 \mathrm{ft}$ sledge back to "First Cachen, where its towing shackle fell off, and it accelerated past them: Spottiswood raced it into cloud above the icefall, and crash-stopped it with his

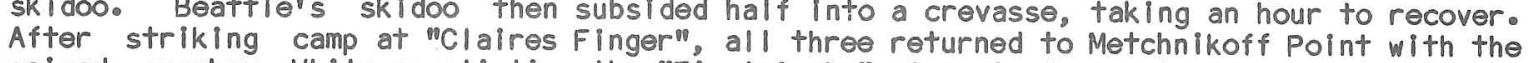
selzed gearbox. While negotiating the "First Cache" slope in dense cloud, Beattie sprained his wrist as his skidoo nosedived off a 3 ft sastrugl, wet weather. Spottiswood measured his length in 6 6" water on the garage floor. Atkins repaired the gearbox by removing the seized others got the Skidoos up the ify traverse to the skyline, with an extra 28 mandays rations all the tent poles had been broken by the runaway sledge, so walked back down to basecamp.
all Finally they returned to the "Claires Finger" cache on 18 th. buried. Two days of high Winds and zero visibility followed, with the tent repeatedly bur iedo Several radio messages were exchanged with Faraday Base. Atkins started
rebulliding the. Alpine 503, working outside in generally desperate weather, having to dig it out repeatedly from drifts. On 21 st Spottiswood and Beattle ferried loads onward in good weather, meeting the NE Coast Pulk Party at "The Burial Ground" cache. Evan's ulcer had
deterlorated, so they ferried him back to Metchnikoff Point, installing him there with the only radio, before returning to "Claires Finger". Another day of westerly gales and heavy route in At lacalised heavy cloud, and camping loads on, repairing two skidoo defects enroute in localised heavy cloud, and camping with the pulk party at "The Burial Ground". over. Atkins completed a succession of repairs on the two ex-Transglobe skidoos, and al so fabricated a metal sledge from an empty 45 gal lon fuel drumo In soft drifts and blasting
spindrift spottiswood and Beattie managed 3 ferry trips up 500 ft onto Roentgen ridge on
24 th and 28 th and also trled unsuccessfully on 25 th. ridge, on 29 th they made 3 ferry runs, moving camp up onto the north side of Roentgen together in driving spindrifte. These were the worst conditions yet met skidooing, a very sorted out stores.

south side of October they ferried all 14 stores loads and moved camp 2 miles to the excellent, carrying a full 45 gal drum, and other loads of 600 motal sledge proved satisfying days work was completed in a rising blizzard which continued until i late on 2 nd.
Atkins rep laced a manifold gasket and completed the Ath ins replaced a manifold gasket and completed the new sledge. At first light $(0600)$ on
3rd, Spottiwood and Beattle recovered the remalns of the stores cached (in May) near Roentgen Peak, before bad weather returned.

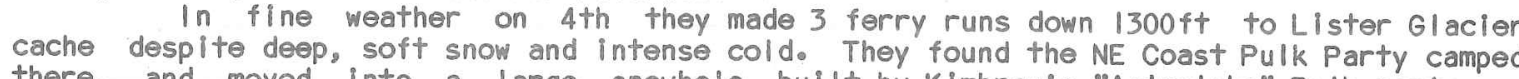
there, and moved into a large snowhole built by KImbrey's "Astrol abe" Pulk party: a
message at the bur ied cache sald the "Astrolabe" party had finally left on 24th September,
after. 

each, alone and unroped on Dutch Courage, while Atkins and Beattie waited below, under an
icefall made more nervewracking by an aval anche nearby. Beattie sorted out the stores again, mustering the rations and decanting all fuel from drums into 55 jerrycans of second metal sledge. weather deteriorated on 6 th. Atkins renewed a rear tracksprocket bear ing damaged by rope,

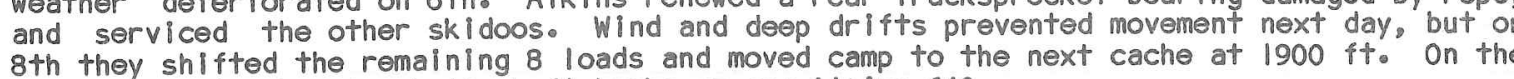
8 th they shifted the remaln shaft broke on one Alpine 64.0.
final run a track drive half she They remained 4 days/5 nights at mit stop Cache" while Atkins worked outside,
completing a very ingenious makeshift repair of the half shafte Spottiswood and Beattie completing a very ing east over virchow ridge in very difficult sofit snow. on 11 th the other
old skidoo sheared two engine holding - down bolts, requiring yet another masterfully inventive repair by Atkins, with no suitable spare bolts. inventive repair by 3 skith all 3 seos servicable at last on i3th they established their planned major cache at $3200 \mathrm{ft}$ at the head of Pare Glacier, on the plateau below the
to Harvey Hel ghts and the south. Starting with about 3 tons of stores, they had delivered

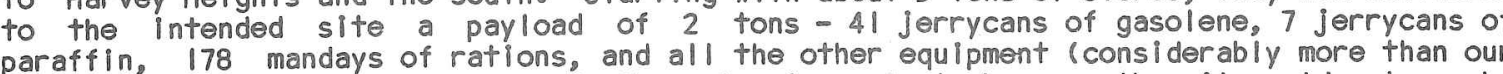
original estimates). Because of the atrocious september weather it would not now be possible to rake the skidoos themselves south over Harvey Heights as or iginally intended, and should also help the Second Summer Party

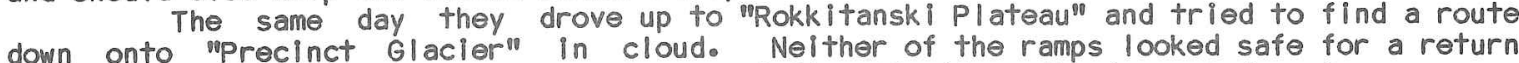
down onto "Precinct Glacier" in cloud. Neither of the ramps looked safe for a remped at $4000 \mathrm{ft}$ after completing 16 mi les, the longest days journey. on 14 th they left the skidoos and hauled 2 very heavy pulks around the flank of Mount Rokkitanski and down to "Sues Col" where Atkins had a nasty slide with a pulk on
steepening ice. In almost continual whiteout they continued to "Astrolabe Point", arriving steepening ice. In almost cont 38 days they had overcome appalling weather conditions, much bad soft snow and a series of

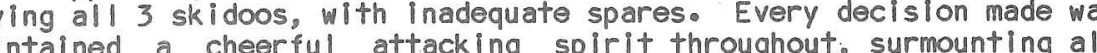

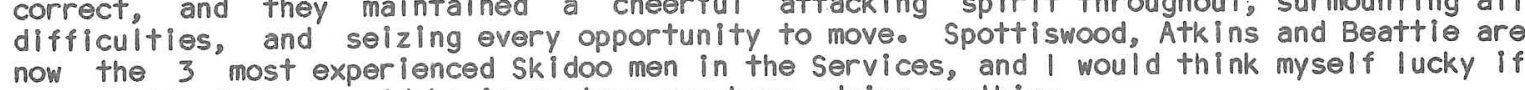
any or all of them could be in my team anyuhere, doing anything.

"Astrolabe" Pulk Party. 6 September-11 October 1984. Kimbrey, Lumsden, Oakley, Stuttardo reaching the "Burial Ground" cache next eveninge On 8 th in worsening weather they moved onto Roentgen ridge, where both tents were buried by drifts despite all-night digginge on Peak, restocking from the cache next day and ascending Roentgen and "Emery" Peaks. 作 Fohn winds gusted over 60 knots on 16 th and 17 th with heavy freezing rain. On 19th Kimbrey and Lumsden's Super Nova was hit by a mini soft-slab avalanche breaking a poleo Next day Fine weather on 21 st was utilised to repair tents and dig out the cache yet again. parties), they finally left the snowhole and pulked across Lister Glacler up to $2000 \mathrm{ft}$ on

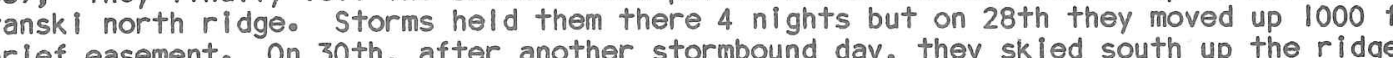
In a brief easement. On 30th, after another stormbound day, they skied south up the rlage,
but were caught by a severe blizzard while in great difficulty pulling capsizing pulks up an icy 40 degree slope. They dug a snowhole before an evening clearance enabled Kimbrey
and stuttard to reconnoltre up to 3700 fto On Ist October they moved up over "Hollys Col" (over 4000 ft), then started
descending into the head of mprecinct Glacier", where they were caught by whiteout in maze of bad crevasses. Pitching tents in a rising easterly, 0ak ley and Stuttard's Superso they collapsed the tent and moved into the other tento. All four lived cramped into the
one tent for three stormbound nights, with an evening break on 2 nd allowing Kimbrey and
stutard tor discover the one route down the crevassed area. They had been IIving on half on 4 th they broke camp before breakfast and pulked down to $3000 \mathrm{ft}$, where the
clouds cleared al lowing them to complete the 6 miles down to "Astrolabe Point". Arriving with just 3 mandays rations between them, they found the top 4 inches of the cache marker pole protruding from

37 hours, In 29 days they had only, had 5 clear of whiteout and been able to move for only Glacler cache they had eaten only 14 days of rations (which were already under $80 \%$ of the 5000 calories per manday considered necessary in these conditions). Unlike the other pulk
party they had not enjoyed the security of skidoo cache support. Their successful journey required all their resource, \& determination and good humour. Ail four earnt great credit, especially Kimbrey the party leader. Without his experience, and in particular stuttar
support. their very survival would have been doubtful in often desperate conditions.

kerosene After one day's recuperation they started digging for the 3 fuel drums cone 33 kerosene and two gasoline), and the stores boxes separately cached, and for 100 mandays
missing compo. For 7 days they dug through deep icy snow to ground level, feel ing weak due to lack of foode. Meanwhile Lumsden caught up the radio backlog and further improved communications, Oakley, recorded bird life as well as conti nued meteorology recording, and
Stuttard began a detalled study of the flowering plants and other vegetation beginnning to entrom snow cover.

Northeast Coast Pulk Party。 6-21 September 1984. Furse, Corbett, de Gerlache, Evans, Ringe。 Pulk Party at "Claires Finger" cache at dusk. On 7th they dug the cache out of $6 \mathrm{ft}$ snow. Ringe arrived that evening with the Skidoo party.
After 2 days stormbound, they moved to Cape Roux East on 10 th. Corbett climbed then delayed them 3 days. ridge, corbett navigating largely in cloud, a very heavy uphill haul in windslab drifts for Evans as horse. Camped beside the cache at 1500 ft Storm Force westerly winds repeatedly half day break on 18 th enabled a short recce trip to the north coast by Furse, de Gerlache and Ringe. Evans had developed a mild duodenal ulcer in August, it was now worse.
sunshine on 21 st allowed the tents to be moved up to the surface and the cache Sunshine on 21 st allowed the tents to be moved up to the surface and the cache
was moved up another 4 ft. At noon Spottiswood and Beattie arrived with 2 skidoo loads.

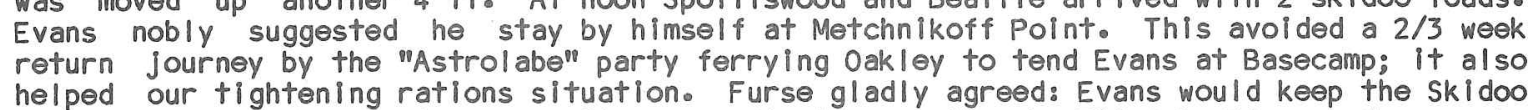
Party radio and request a precautlonary medl lal evacuatlon by RRS John Biscoe, due nearby
shortly. Within an hour Evans was waving farewell from the back of a skidoo heading home. $\frac{\text { Northeast Coast Pulk Party. } 21 \text { September-11 October 1984. Furse, Corbett, de Ger lache, Ringe. }}{\text { After Evans' departure they relayed the pulk onto Roentgen ridge. The Equinox }}$ was yet another westerly gale, but on 23 rd they checked the cache near Roentgen Peak, then visited Cape Cockburn
Burial Ground in cloud. Bulial Ground" in cloud.
on 24 they moved in cloud to Roentgen Peak, pitching camp in rising wind and
falling snow. Westerly winds (reaching 80 knots on two days) held them there for 6 nights with only two brief breaks. Freezing rain on 25 th provided a helpful rigid armour-plating Duclaux point. Ringe visited an interesting basalt formation nearby on "Vango Ridge". only 2 rock outcrops. After a gale next morning the weather cleared. A BAS Twin Otter was

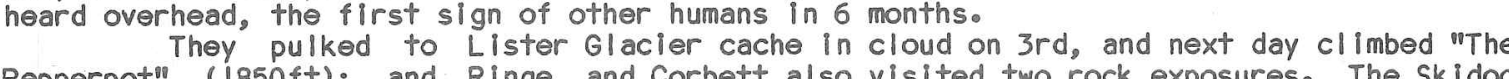
Pepperpot" (1850 ft); and Ringe and Corbett also visited two rock exposureso The Skidoo

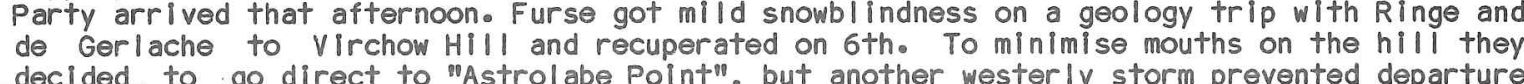
Duther westerly storm prevented departir Helped by the skidoos (and now with a second pulk freed by Atk Ins' second fuel
drum sledge), they ascended Lister Glacier on 8 th to camp at 2500 fto Fine weather at last preval led and after camping on "The Terrace Pledmont" and west of "The Precinct", they

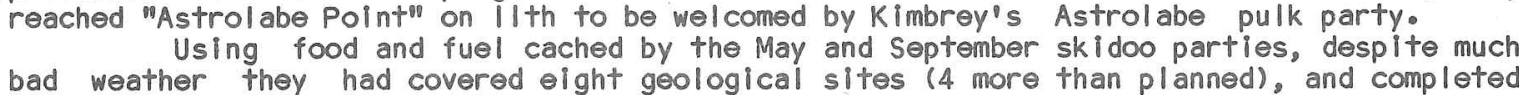
bad weather they had covered e
the geology south to Virchow HIII.

$\frac{\text { Metchnikoff Point. } 21 \text { September-3 November 1984. Evans. }}{\text { Returning by skidoo on } 21 \text { September with a worrying duodenal ulcer, Evans }}$ remained alone in Basecamp with the only clansman radio then manned by the expeditiono. He
established communications with Faraday, and requested a precautionary medical evacuation. Late in september was not possible, but BAS agreed that the RRS John Biscoe would attempt to pick him up on 4-6 November if weather permitted, or otherwise on 26-28 November. Falling that, USARP also agreed that USCGS Glacier could recover him on 4 December by
helicopter. These generous of fers typifled the helpful actions of the British and US sclentific authorities in such cases of real need. covering a gap in our observations, and tending and clearing up Basecamp. He also
continued his beach study. He later sald he had not felt lonely, spending much time

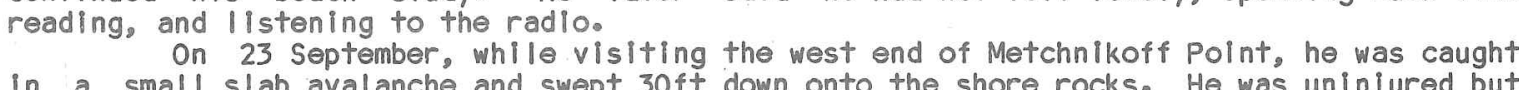
in a small slab avalanche and swept $30 f+$ down onto the shore rocks. He was uninjured but lieing awkwardly, with his legs buried and clamped in snow. The waves breaking on him
first consolidated the snow debris, but then gradually helped remove it. Finally he freed himself by pulling his foot out of his boot, after a frightening experience, without hope
of help. On 5 October he at last heard the "Astrolabe" Pulk Party on the radio, and thereafter was in daily contact with one or another of the parties. The first few Chinstra present. There were many other signs of Spring, with increased radio traffic, a plane

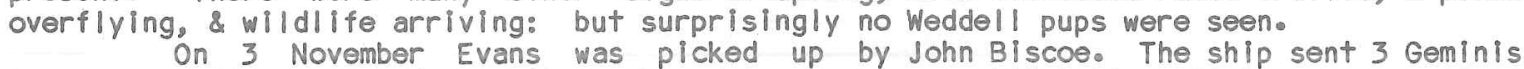

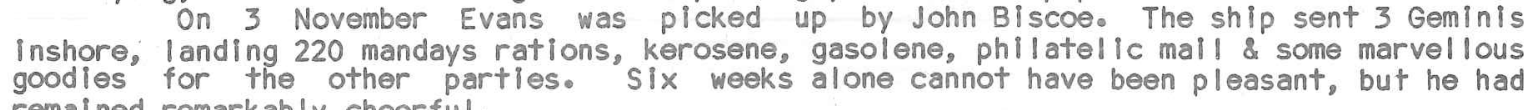


34 "Astrolabe Point" 11-14 October 1984. Furse, Corbett, de Gerlache, Kimbrey, Lumsden, Oakley, Ringe, Stuttardo 0 i2th the Astrolabe Pulk Party continued digging for stores, whlle the others took a Sunday. For the next 2 days the skyline. Meanwhile oakley and others completed the digging: after 550 cubic yards (over 200 tons) of snow had been excavated it was ultimately clear that monstrous waves,
perhaps early in August, must have overwhelmed the $15-20 \mathrm{ft}$ basalt "seawall" and swept away the lower cache from 60 yards beyond, nearly $30 \mathrm{ft}$ above high tide level. 3 fuel drums, 9 mandays compo and other stores were missing: luck lly the upper cache a few yards further up had escaped. With fur ther asteveryone until late November: In continuing fine weather, Ringe \& Stuttard progressed geology and botany, both most interesting there. Drastic revision of plans was necessary because of several factors: the loss of
stores from "Astrolabe point";"; the delays due to september weather; a signal just receive strom Endurance required the whole team at Metchnikofif Polnt for" the changeover: ser lous

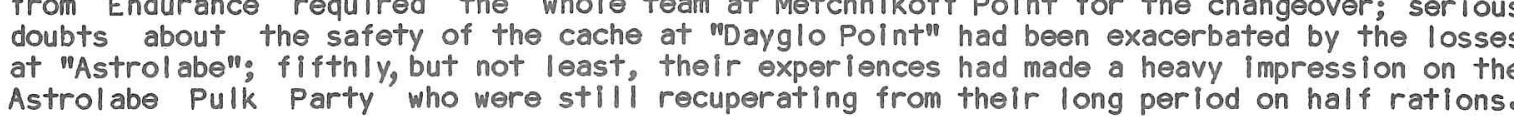
Plans were constantly discussed. check the cache there. (Ringe al so volunteered, but completion of geology in the north was considered more important). With Evans having the second radio at base camp, there was no communications with the Skidoo Party. So on 14 th Furse decided to move up over "Rokkitansk
Plateau" next day with de Gerlache and Lumsden, to 1 ink up with the Skidoo Party, before
continuing to "Dayglo Point".

$\frac{\text { "Astrolabe Point", 14-17 0ctober 1984. Whole team, except Evànse }}{\text { On the evening of 14th Spottiswood, Atk ins and Beattie tumbled cheerfully into }}$ the campo Their arrival enabled more coordinated and better plans. The mealn body would
attempt the first ascent of Mount Parry. After helping the first stages of portering attempt the first ascent of Mount Parry. After helping the first stages of portering,
stuttard would return with oakley to wstrolabe Point"n to progress ologies. Atkins volunteered to join the "Waygl o" party after the ascent of Mount Parry. On 15 th portering 270 mandays Arctic Rations up to $1000 \mathrm{ft}$ was comp
16 th was a Sunday, allowing everyone to rest and prepare for weeks in the hills.

First Ascent of Mount Parry. 17-31 October 1984. Kimbrey, Atkins, Beattie, Corbett, Furse, $\frac{\text { de Gerlache, Lumsden, Ringe, Spottiswoodo }}{\text { As the most experienced mountaineer and climber in the team, Kimbrey organised }}$ and led a Himalayan-style assault from sea level, portering and sledging a loglsto the ridge. Additional food was taken from Asstrolabe for subsequent exploration around Mount Mor and forties. around the foot of Mount Rokk itanski. Ringe and Atkins remained for 2 days making a geological map of "Astrol abe Point"
before joining the others, who left on 17 th. For 3 days in cloud but little wind, two parties leapfrogged camps to "sues col", and ferried loads in short stages up the NW ridge of Rokkitanski to $3700 \mathrm{ft}$, using all 7 pulks,
on $20 \mathrm{th}$, in brliliant calm sunshine, a good route was found up from the top bowl on 20 th, in brilliant calm sunshine, a good route was found up from the top bow
of "Precinct Glacler" Kimbrey, Spottiswood and Corbett moved up to camp at $4300 \mathrm{ft}$ on
"Rokkitanski plateau" and made two skidoo trips down to $3700 \mathrm{ft}$, bringing rock samples and biscuit for "Astrolabe Polnt" and taking rations back up.
Oakley \& Stuttard had assisted portering up to $3700 \mathrm{ft}$. On $21 \mathrm{st}$, with mixed work of higher prior

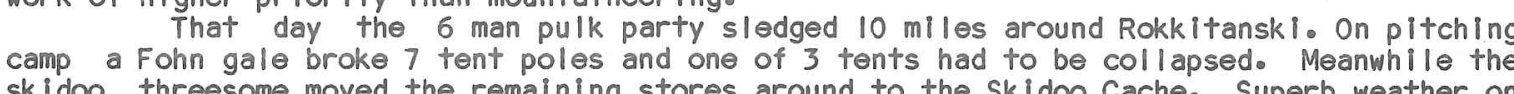
22nd al lowed the advanced basecamp to be establl shed with all stores at $3700 \mathrm{ft}$ at the foot of Pare I cefall. Atkins and Beattie reconnoltred the I cefall behind camp, finding a Every evening Lumsden worked the radio. As well as continuing communication with to talk direct with VPC Falklands. We asked RRS John Biscoe to embark food and fuel fro the Army in Stanley, hoping it could be landed when picking up Evans, and thus avoid the
need to take penguins eggs and seals at base in December. In two days 256 mandays rations etc were portered halfway up the icefall (five
return trips each, all sweating in calm cloud) and the team moved up to Camp 8 at $4800 \mathrm{ft}$ o return trips each, all sweating in calm cloud) and the team moved up to Camp 8 at $4800 \mathrm{ft}$ on camp 9 at $5300 \mathrm{ft}$ on the edge of the whaleback ridge. Furse broke a ski-binding on the final lift: so on 27 th Kimbrey and Spottiswood returned 6 miles to the skidoo Cache (in cloud below) to collect the spare binding, while the others ferried gear $2 \mathrm{miles}$ up the
ridge to $6300 \mathrm{ft}$ in glorlous weather. Kimbrey and Spottiswood returned early on $28+\mathrm{th}$, after some difficulty at the widened schrund halfway up the ficefall. The team then sledged the final loads onward, and moved up to establish Camp 10 at $6300 \mathrm{ft}$, before taking 4 pulk loads on to $6400 \mathrm{ft}$ at
"Scotch Corner". Waking to another sunny day at 0400 on 29 th the team with 5 days rations and 2
pulks first established Camp 11 at $8000 \mathrm{ft}$ on the north summit of Harvey Helghts befor midday, then continued on skis with 11 ght packs to the south end of Harvey Heights, befor changing to crampons for the final impressive ridge. $500 \mathrm{ft}$ below the summit spottiswood
Furse turned back exhausted. At 1620 Kimbrey triumphantly led the other six to the summit Furse turned
$(8,400 \mathrm{ft})$.

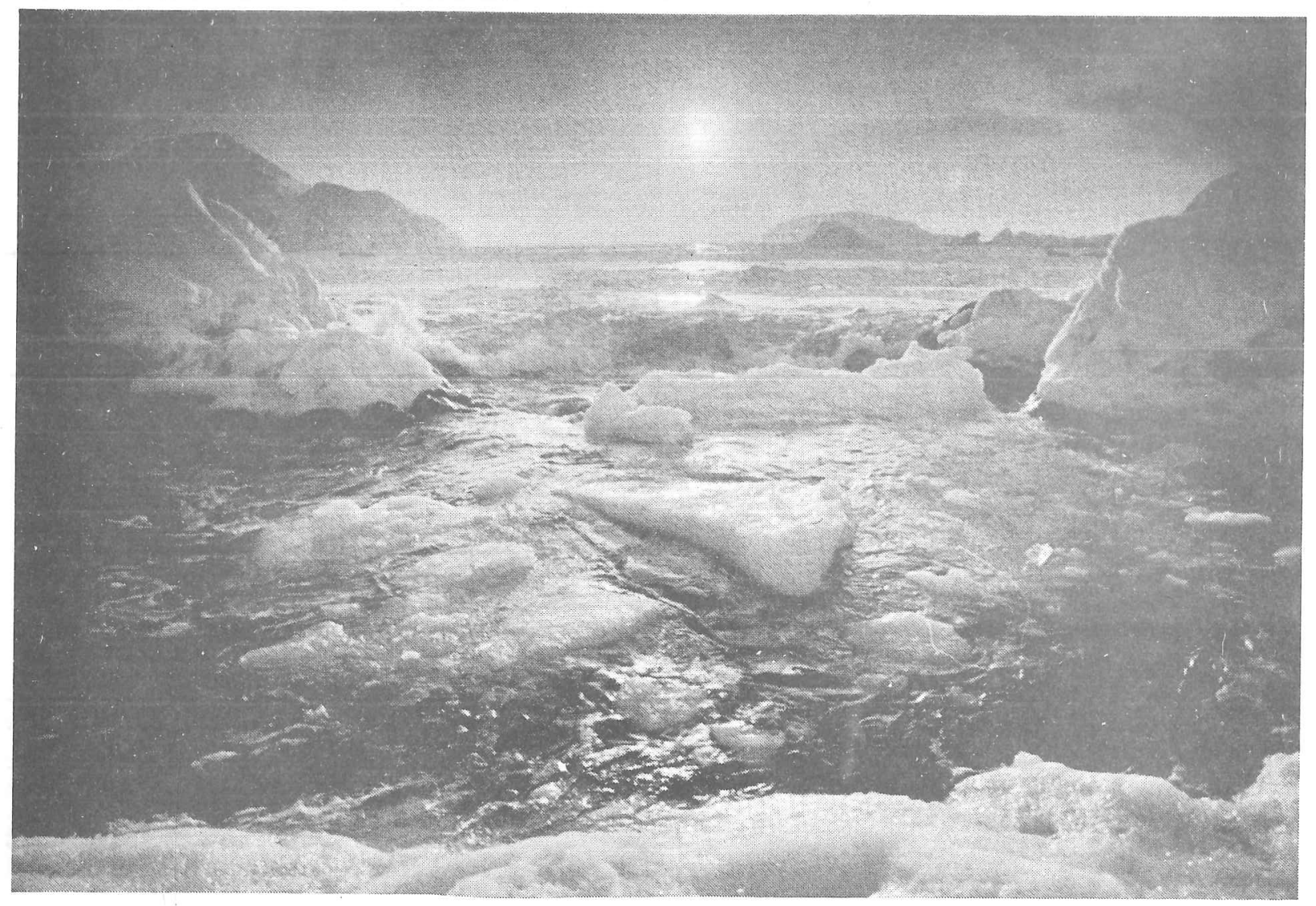

Midday in winter. Looking North from Metchnikoff Point.

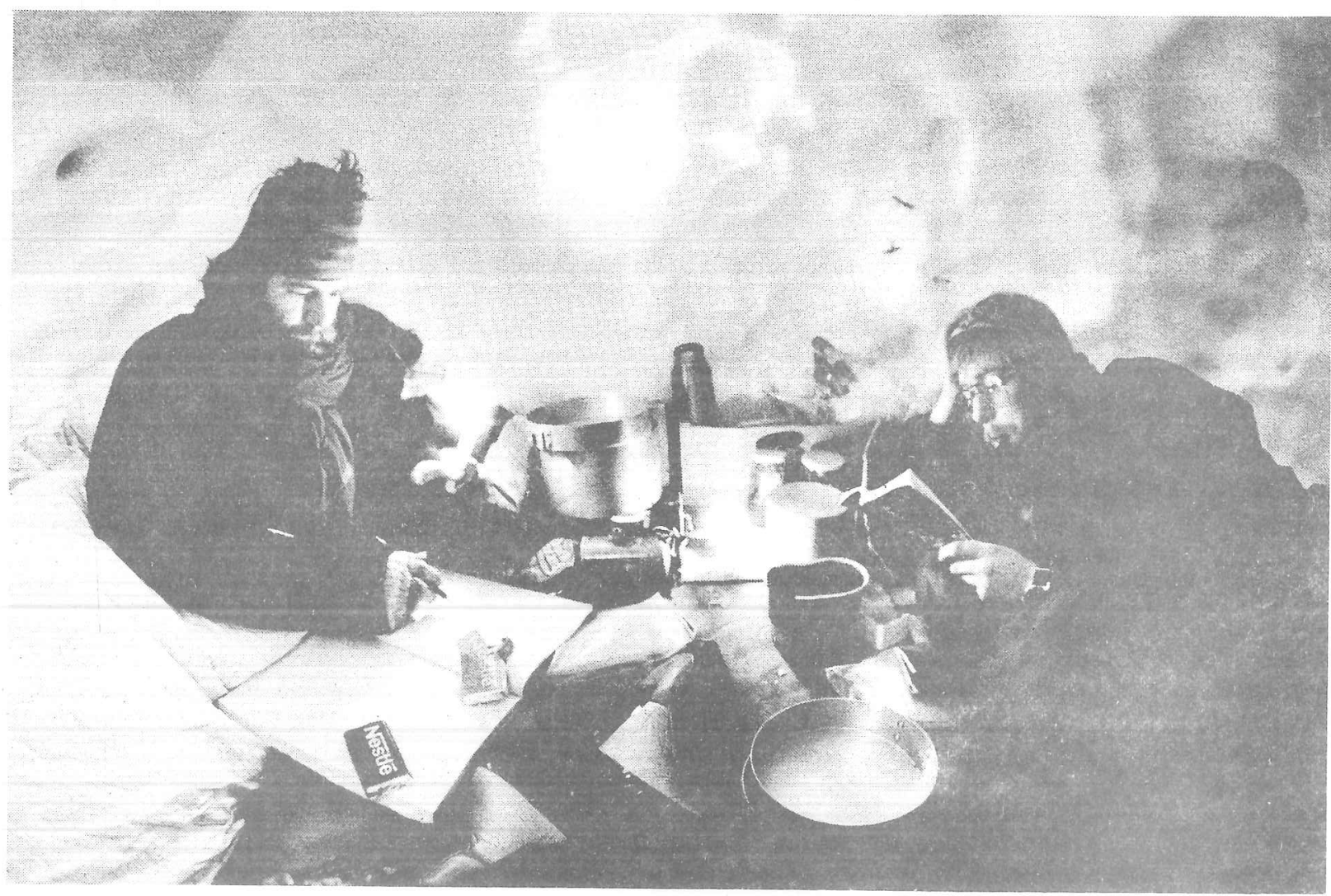

Snowhole. Atkins and Beattie sitting out a blow during the sledge recovery in 

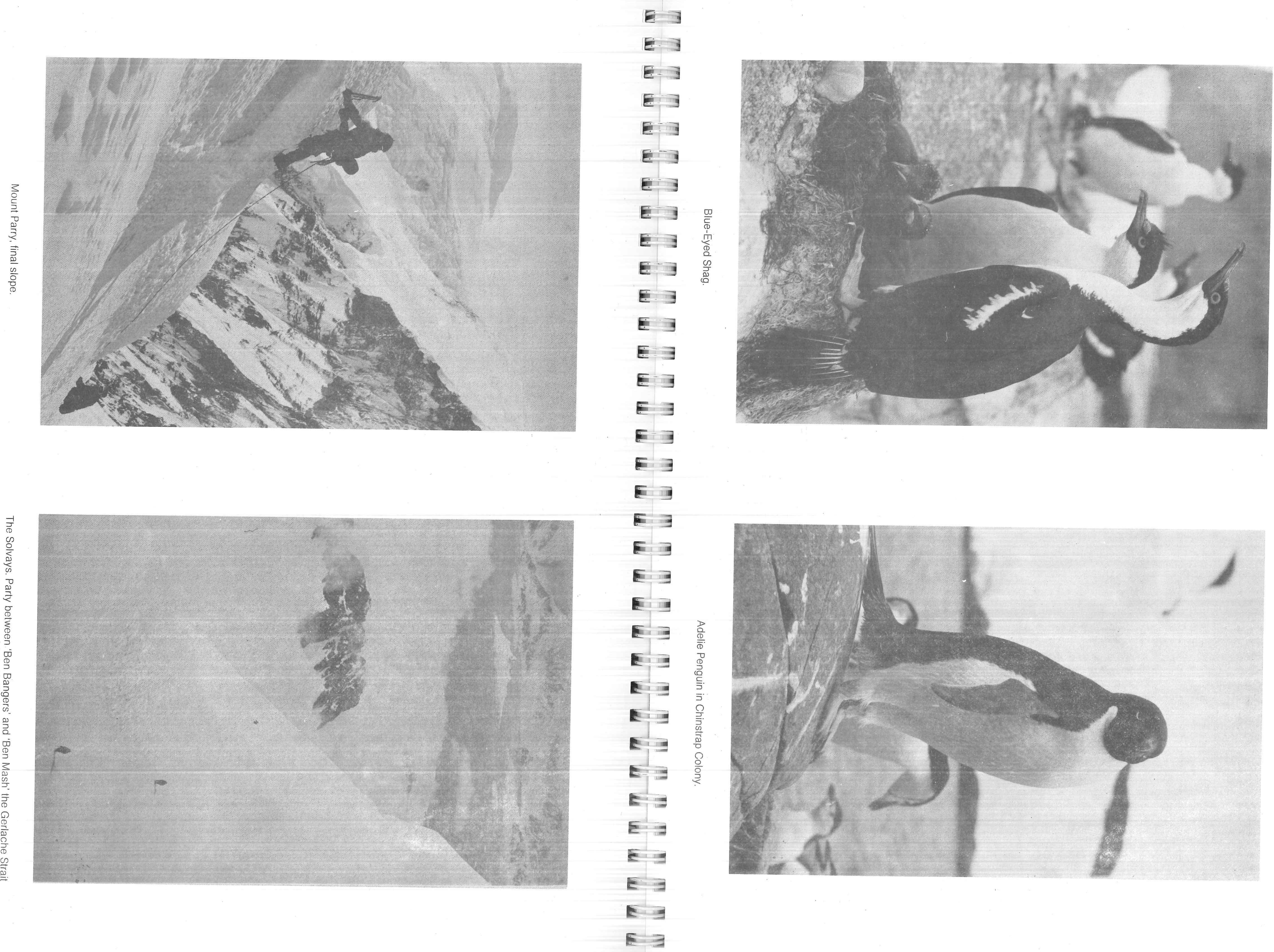


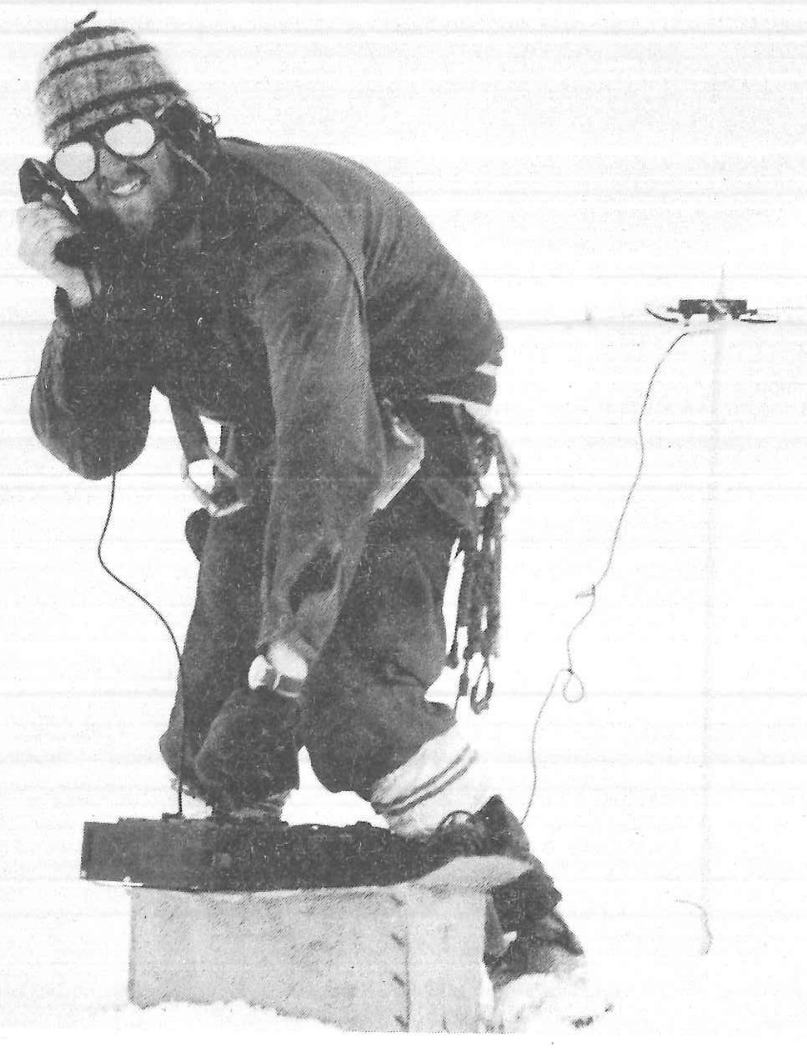

Radio. Lumsden using the radio in fine weather in October.

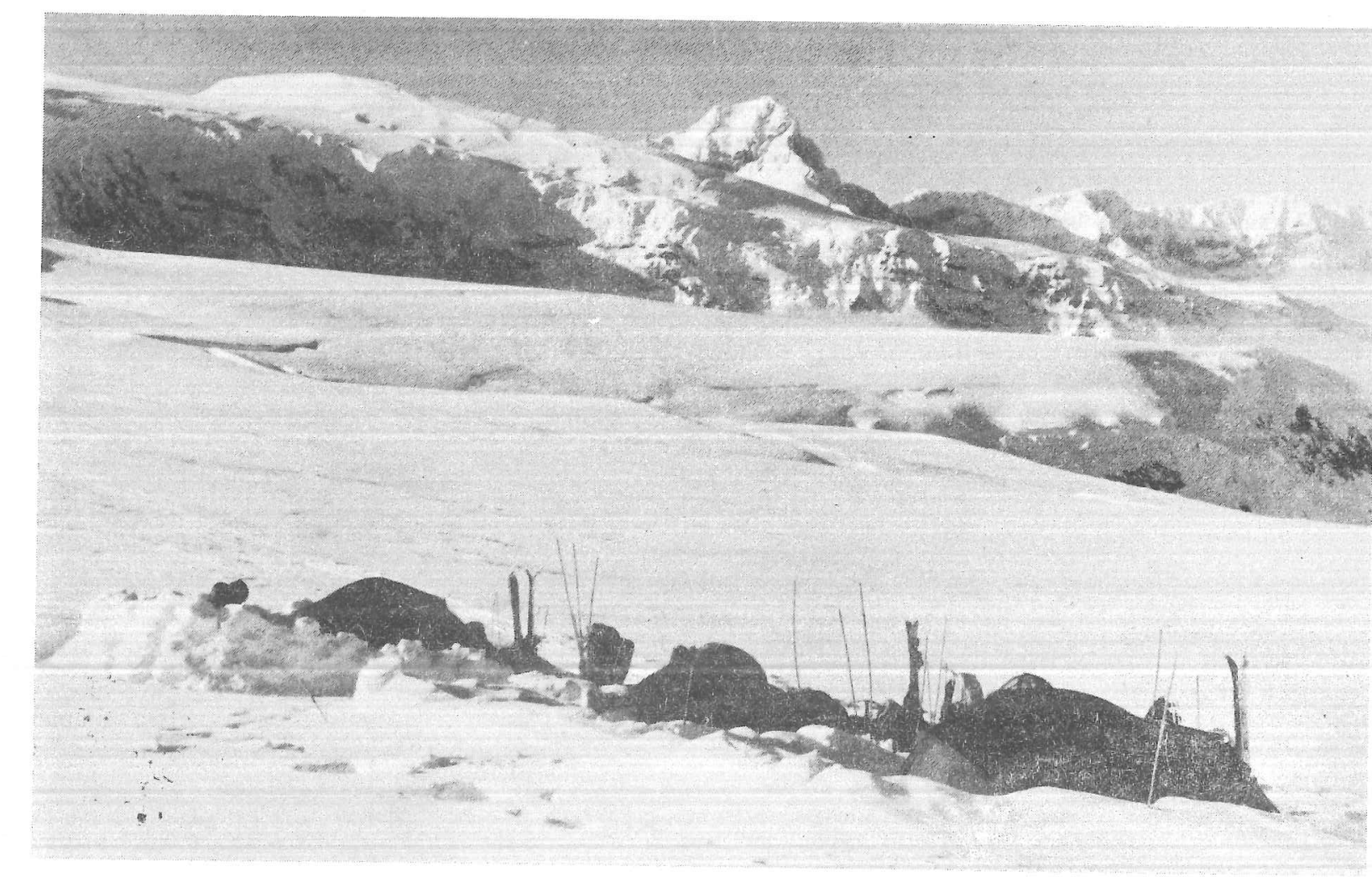

Ascent of Mount Parry October 84. Mount Parry from the second porters' camp above 'Astrolabe Poin'.
After still and cine photography by Corbett, Ringe collected basalt from $7400 \mathrm{ft}$
on the summit ridge (possibly the highest rocks collected in the Peninsula last of the seven returned to camp by 2100 , as the sun set behind Mount Francals: all wer
exhausted after a very long and hard day. Heights and portered the Dayglo party stamp down to $7000 \mathrm{ft}$ on the NE shoulder of Harvey weather Atkins and corbett made another ascent of Mount Parry Corner" visibility under 50 yerd main slooft southern summit of Harvey Heights; on 3 Ist with made and drifted camp, heavily drifted by the high windse 16 days, including 2 rest days. Team members had averaged 85 miles travel each, with 701 bs on pulks; average personal \& tent packloads when moving camp were 60 lbs, plus up to exploited leadership and detailed organisation, with all-out effort by everyoner ho At the same time adequato achleve the ascent just in time before conditions deteriorated Bay parties. Although no pitches mountaineering skilis, and all the logistics of a Himalayan ascent (except paid porters) After a day of bad weather on 31 st, the HIII Bay Southern Party. 1-18 November 1984. Beattie, Kimbrey, Ringe

$5100 \mathrm{ft}$, their base for geology and ski mount sinoulder of Harvey Heights and pitched camp at several Next day they coll lected rock samples at wFreud Heights", where they al so found they made the First Ascent of Einthoven Hill on 5 th: Ringe Aller a days bad weather three $3700 \mathrm{ft}$ " $\mathrm{sSSH}$, beaks" bere they returned in cloud. On 6 th they made First Ascents of the was incorrect. (SeQ Survey Report). Hill Bay, finding out that a ring contour on the map plod in sticky snow, and were then held up by 2 days snow and high windso Corner" cache at $6400 \mathrm{ft}$ on Harvey they dragged the pulk up through heavy snow to "Scotch day they collected basalt at 5000 it along the Morgagni spur, enjoying fantastic vlews down

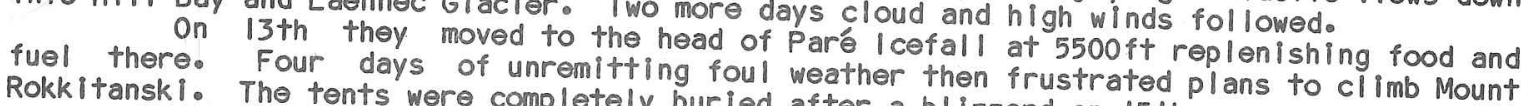
beside Spottiswood and Corbett's descended the icefall in clear windy weather and camped

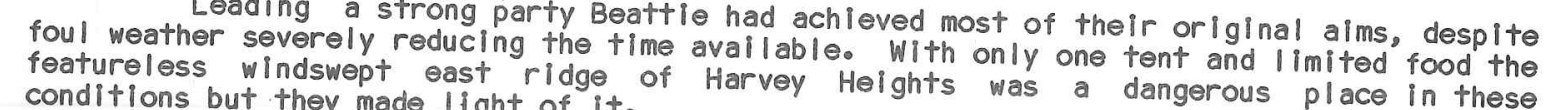
Hill Bay Northern Party. 1-18 November 1984. Spotti swood, Corbett.

Pare lcefall, camping beside the parked skidoos. Harvey Helghts to 3600 ft at the foot of the Five days bad weather followed with much snow and to the main skidoo cache and dug it out. to the skidoo cache, digging it bad weather, with a 50 knot blizzard on 15 th, then prevented any outside movements beyond
digging out their super Nova tent, and having digging out their Super Nova tent, and having to move it when too heavily drifted. ice pyramid on Morgagni spur (With corbet leading and Spottis theod fine $4400 \mathrm{ft}$. snow and

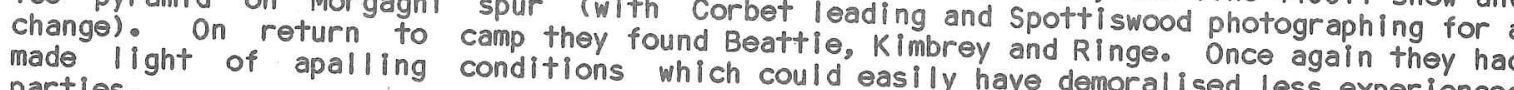
Paré Glacier Party. 18-30 November 1984. Kimbrey Beattie Corbett Ringe, Spetisto making two skidoo trips in whiteout. Heavy main skidoo cache at 3000 th on pare Glacler, aim was to make the first ascent of Mount Morgagni, but time and food were running sheir for relief of Oakley and Stuttard at "Astrolabe Point". Kimbrey generously stood down to "barging" On 21st Spottiswood \& Beattie took 2 skidoos to "Morgagni coll", unroped to allow from the col they found deep soft new snow on the steep face After skiling up the lcefal prevalent on Lister and Paré Glaciers, and aval anche risk a combination of the conditions before reaching camp. They hurrledly pitched their one Sup by an unheral ded bi izzard just The tent stood up to very high winds for their one Super Nova and all four pilled ine reduced to $2 / 3$ rations, as did KImbrey, alone with two nights without a snowwall. They cache. Early on 23rd they moved to the cache, in a short break between high winds and For five days heavy snow fell, totally burying the cache, the upended 8ft sledge minutes to reach the other tent only 15 yards away on the 1 lat. They red Kimbrey took 20

s



taking fuel, as had been planned. The pre-arranged first al ternative was to park the skidoos at $1000 \mathrm{ft}$ above "Astrolabe Point", leaving everything else at the skidoo Cache,
ready for the Second Summer Party landing (expected to be at "Astrolabe Point" foll lowing "Rokkitanski fine weather on 30th Spottiswood barged a 2 ft trough up to $4300 \mathrm{ft}$ on "Rokkitanski Plateau". The 3 mlle journey took 7 hours and Dutch Courage required plugs
renewed twice and 2 new drive belts. Beattie and RInge spent 2 hours digging out the old skidoos halfway up before getting tows from Dutch Courage. Break ing camp, Kimbrey
corbett were dropped off at 1700 to return to Metchnikoff Point, while the others continued toward "Astrolabe" by skidoo. Morgagni ridges clearly acts as a trap for moíst northerly airstreams, caus Ing much clou a month of unusually bad Spring weather, without serlous difficulties. This apparent eas

"Astrolabe" Rel ief Party. 30 November 1984. Spottiswood, Beattie, Ringe.

Plateau" on good hard of "Precinct Glacier" and then over "Sues Col", to park them at the loooft cache onto "Astrolabe Point" - a quick 3000 ft descent in 3 hours. falling $35 \mathrm{ft}$ into a cavernous crevasse: he was held by Ringe. Although initially, hanging upside down with his rucksack, he climbed out uninjured 45 minutes later, after Beattle had chopped away the lip where the rope had bitten in $3 \mathrm{fto}$. They reached "Astrolabe
point" at 2100 . "Astrolabe Point" Scientific Party. 21 October - 30 November 1984. Oakley, Stuttardo stores up to 3700 ft beyond "Sues col w. 21 st october with one pulk, after helping to porter Stuttard undertook detalled work on vegetation transects, and particularly monitoring of clothing assemblages was frustrated by higher air temperatures, but instead oakley worked with stuttard on micrometeorology and made a terrestrlal invertebrate weeks, overlapping and correlating with Evans' observations at Metchnikoff Point, and providing our only information over the important month of November. october, and some storms in November. Rough seas in mid-November again overwhelmed the "seawalin although they did not quite reach the camp? stuttard had an involuntary swim the the "moat" while photographing the breakers. by Furse). Without a radio, they became increasingly concerned about the safety of the others in the foll lowing woek. They finished their compo (exclusively Chicken in Brown better weather on 29 th. they ate their first Chinstrap, and counted I impets on the few
accessible rockshelves. They were very glad of company when the others arrived late on 30 th.

$\frac{\text { Claude Point Pulk Party.1-12 December 1984. Stuttard, Beattie, Oakley, Ringe, Spottiswood }}{\text { On Ist they prepared the stores cache for recoverles }}$ loaded the pulks on the glacler. On 2 nd they moved out with 3 pulks, made up to 77 mandays Dutch Courage and the other skidoos; they camped near the $2000 \mathrm{ft}$ cache. 2000 ft above 3rd they cached most of the rir food on the ridge and skled down to camp at were spent exploring the clifftops to claude point, covering geology, botany, birds and
bugs. (Stuttard and Spottiswood also searched for the fabled middle route onto mprecinct Glacier"). On 6th they pulked through "The Precinct" and camped in warm cloud on the "Terrace Pledmont", where they were held up for a day by wind cloud on the gales and spindrift stopped them there for 3 nights, until 11 th, when they moved on the camp at $2000 \mathrm{ft}$ on mpinnacles Spur". Ringe added to his August rock collection from the
pinnacles, stuttard rightly set aside his plans to climb Mount Hunter from the SW, because
of the high risk of avalanche. journey. By they ing a heavy load of rations stuttard had enabled thorough ologies on the

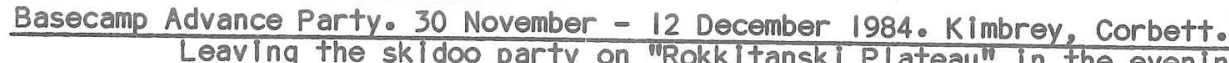

the ridge to "Cushing Col" party on "Rokkltanski Plateau" in the evening, they skled down unclipped from the pulk, which toboge pulk. stopping to rest at "Noddies Col", they and exposed fllmo Luckily they found it safe a mile below. Afer camping that night at
"Noddies Colo" they reached Metchnikoff Point pm Ist December, finding a message from Evans

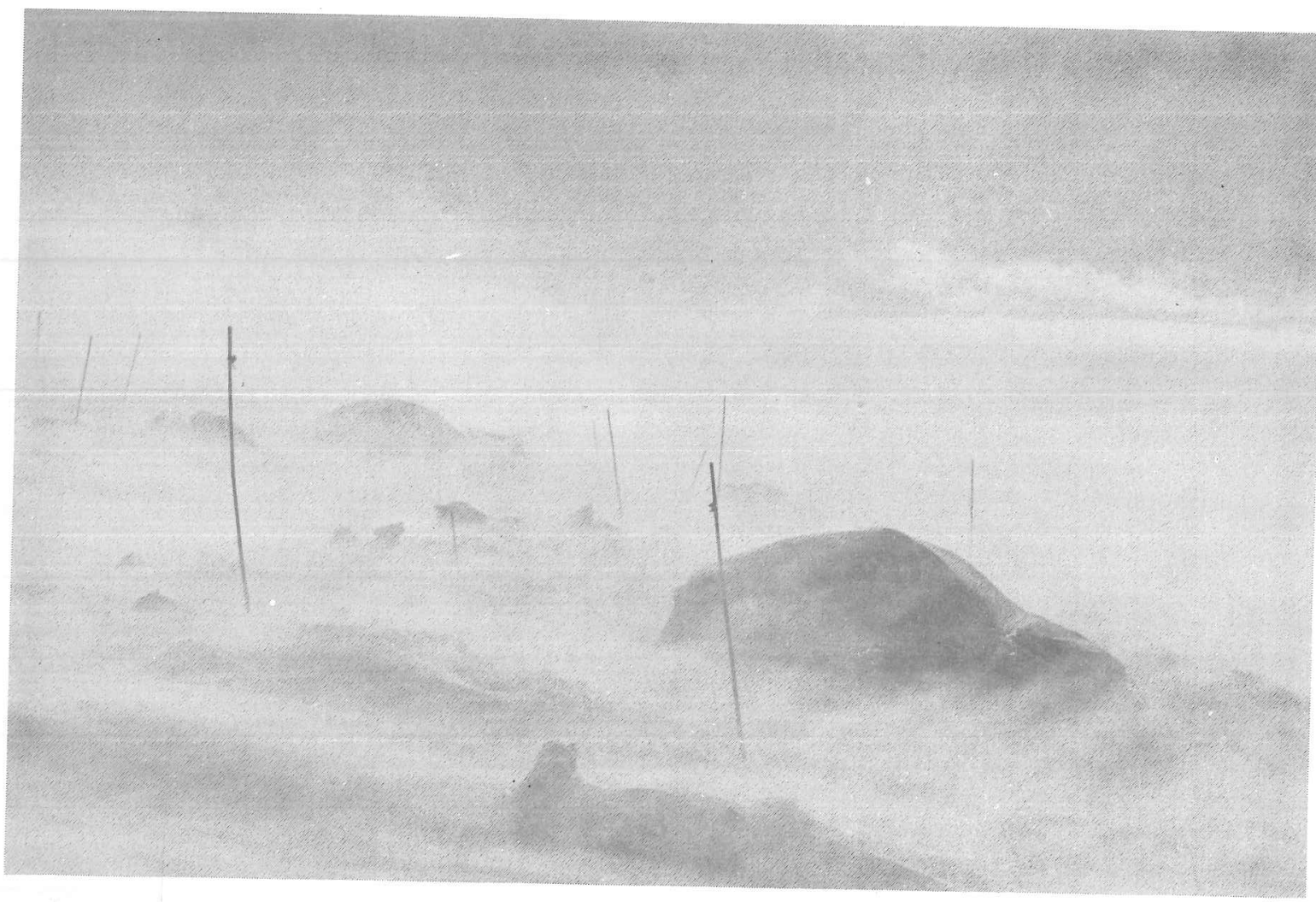

November weather was as bad as September. Two super Novas in spindrift.

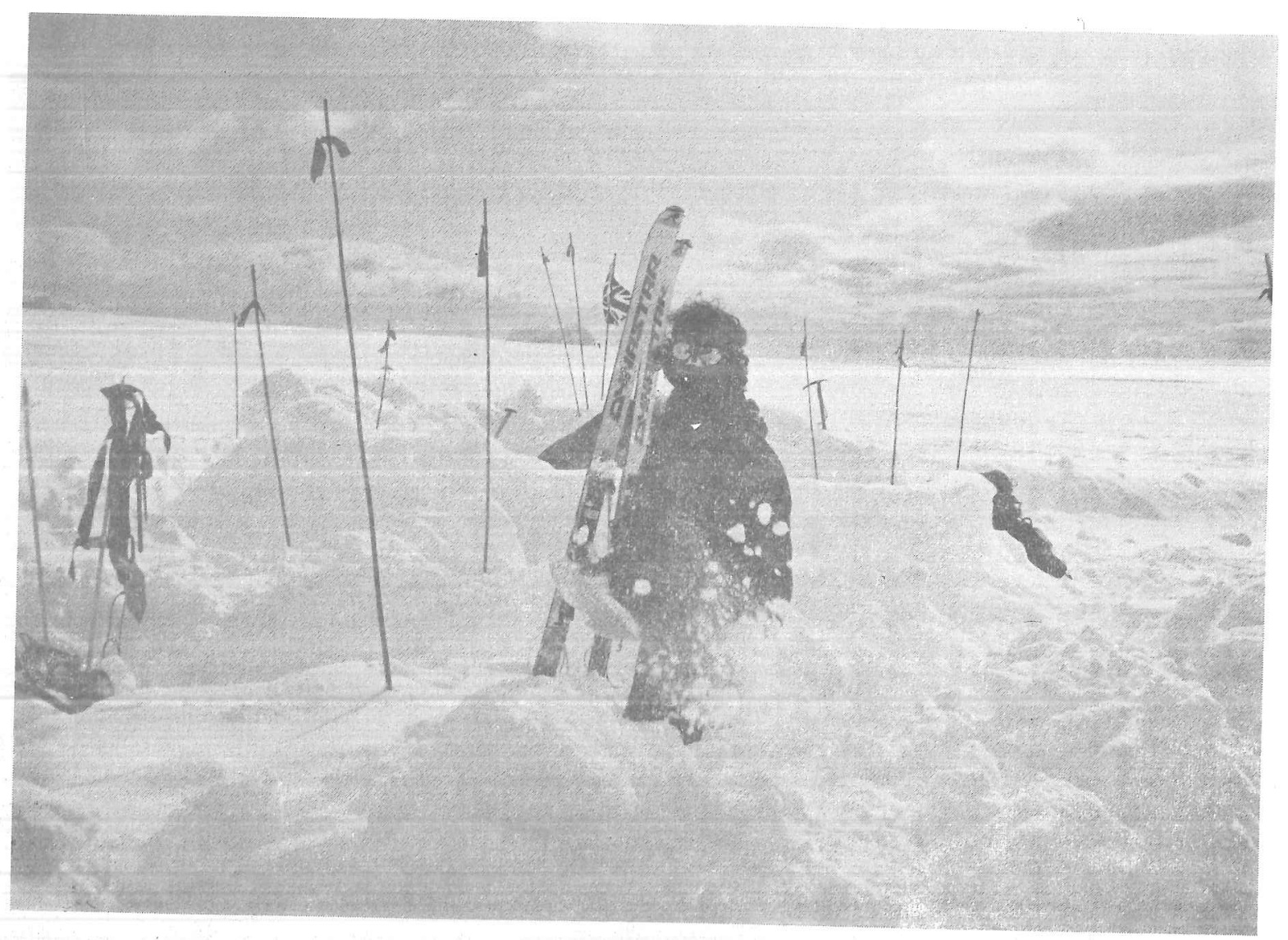

Lumsden repairing snow walls in fine weather. 


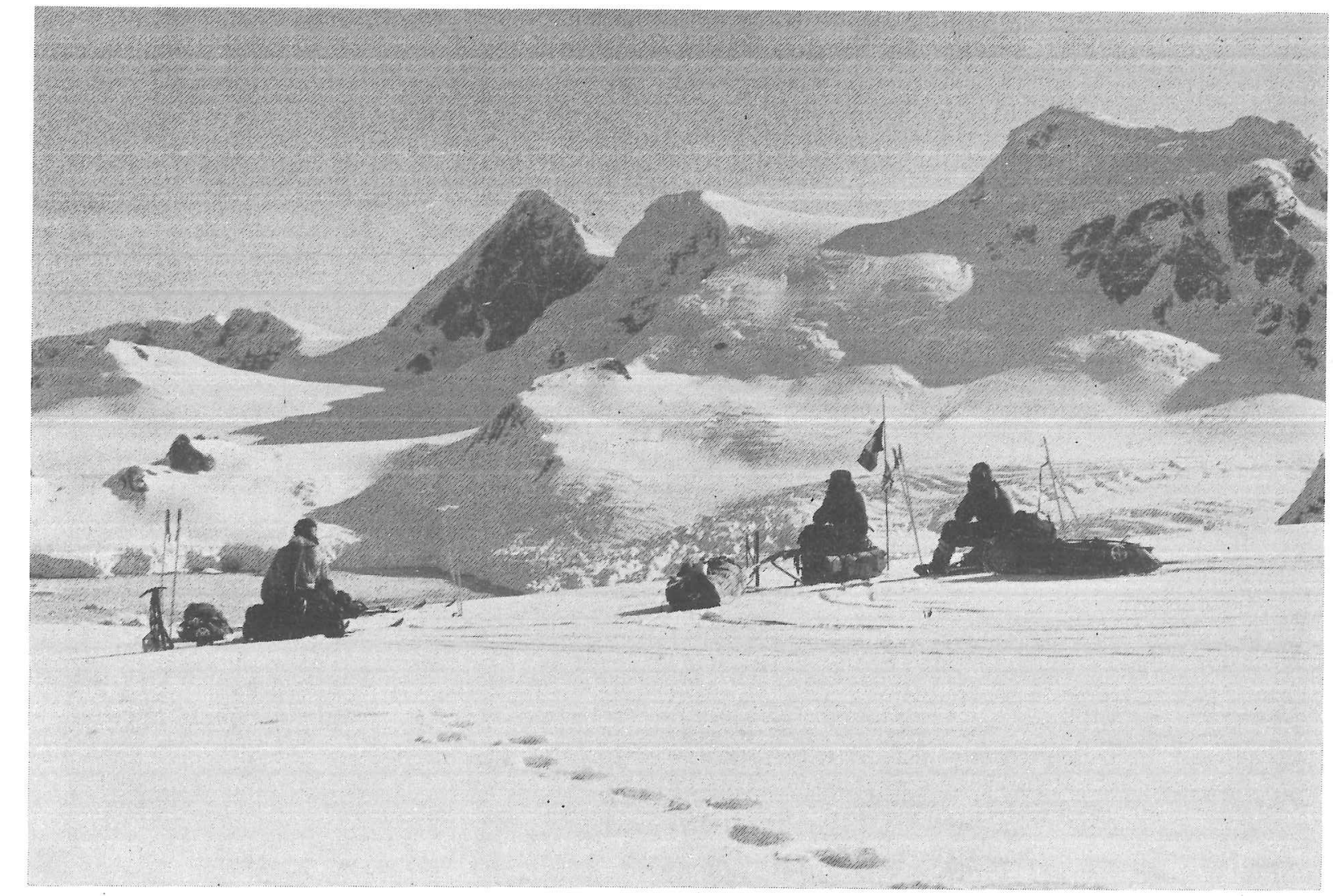
'Dayglo' party above Buls Bay in November 84. Looking across to Celsus Peak

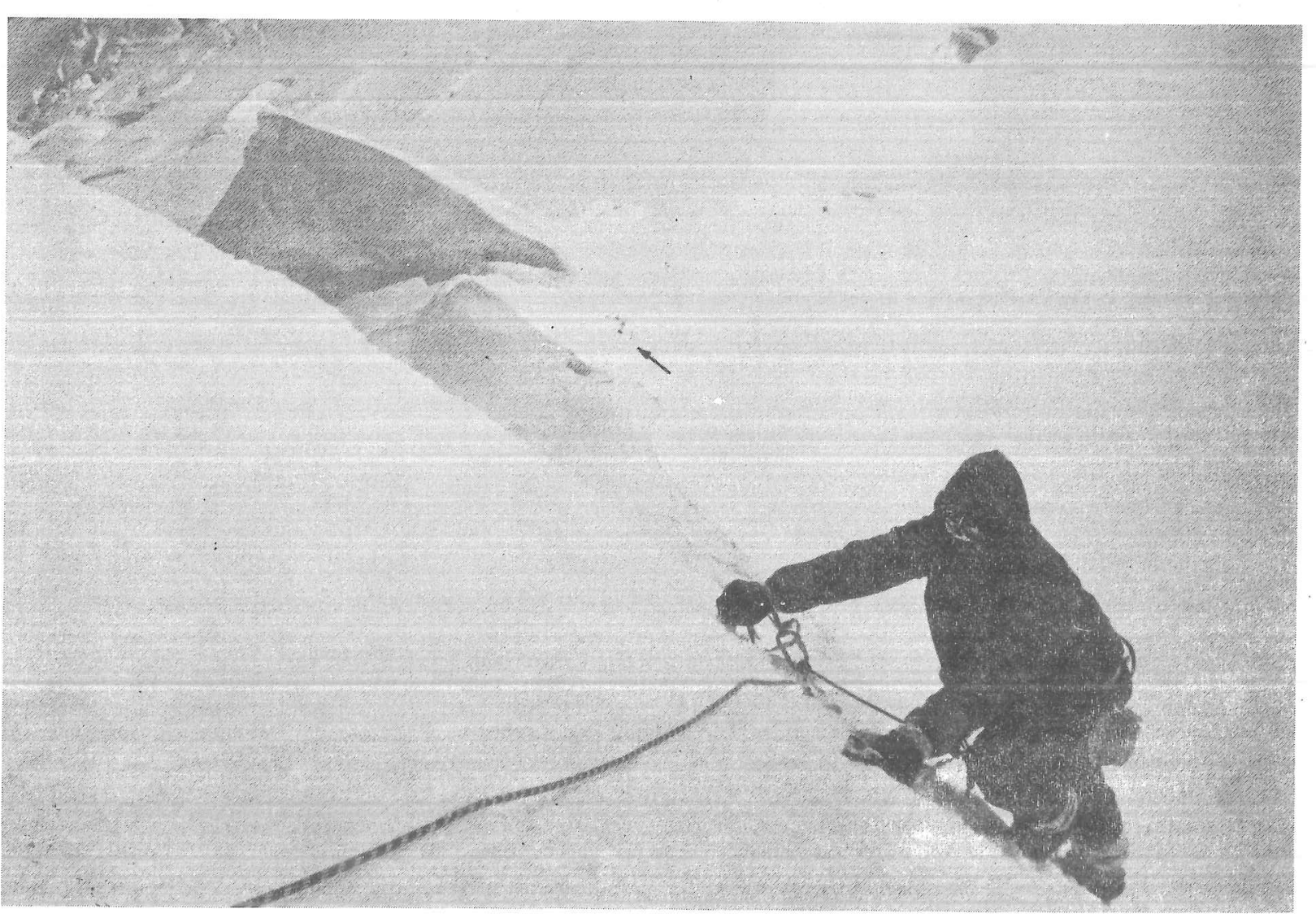

Celsus Peak. December 84. Lumsden above the cached skis (arrowed). Later he fell $130 \mathrm{ft}$.
Next day they made radio contact with the Dayglo Party, and for the next two
two parties were in regular contact. It demonstrated how much better it would

The triwall Hut contact between parties throughout the year. They dug out the goodies left by RRS John BIscoe, dug out the boats which had been drifted boxes. Hall and rain on 8th, 9th and 10th removed 3 ft of snow, and exposed a lot of gash lost through the winter months, and they began a major clearance. laughter soon gave them away.

Dayglo Party. I November - 15 December 1984. Furse, Atkins, de Gerlache, Lumsden

The aim of this party was to check the doubtful cache af "Dayglo point"in, so that
the second Summer Party could efficlently plan their exploration of the south, even if they On Ist November, they left the remainder of the Mount Parry team at the $7000 \mathrm{ft}$ camp on Harvey Helghts, taking 3 pulks, very heavily laden with $4 \times 25$ mandays rations, 12
gallons Kerosene, the (only) radio, and miscellaneous stores to digging work, and possible retreat if the cache was losto In 3 days glorlous weather they travel led steadily downward, camping at $5000 \mathrm{ft}$ above Malpighi Glacier and at $2100 \mathrm{ft}$ on

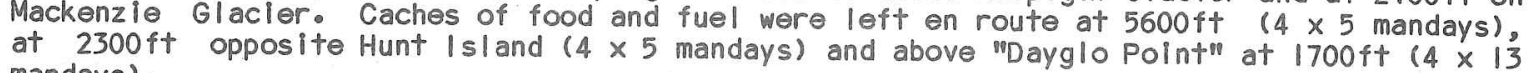
visible and evidently secure. Two days of gloating, overeating, digging out and mustering Mountains, and visit Humann and Fleming Points. The l700ft cach wo to explore the Solvay mandays plus porridge oats and breadmlx etc. High winds on 9th discouraged high travel but furse visited Buls Bay, on a pilgrimage with de Gerlache.
On 10th RRS John Biscoe was sighted, the first ship this boat. The two crewmen were the first outsiders in 8 months. Evans was aiso in the boat, saying hello after 7 weeks separation, and also farewell. They took the "week Iy" radio bulletin covering the ascent of Mount parry, as the radio appeared to be deado

and whisky), but Atkins and de Gerlache made a final stores lift on skis. Atkins, fruit into a crevasse, but was well held by do Gerlache, and climbed out with minor High winds prevented departire to the $1700 \mathrm{ft}$ cache; de Gerlache was promoted to a "Second". the icecliff's set up waves that lapped onto the camp sp it at "Dayglo point" totally self-supporting 30 , day hav explory l-man pulks were haul liod inland to $2100 \mathrm{ft}$. This After 2 days ifirst heavy snow \& then a blizzard) "Black Sheep Top" four days of frustration followed with cloud and snow, although une nealay

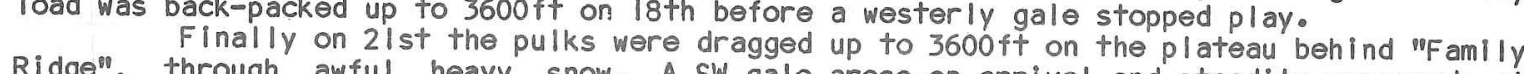
Ridge", through awful heavy snow。 A SW gale arose on arrival and steadily worsened: at 0300 next morning both tents' snowwalls were blown down, but Atkins plugged the gaps. After reaching a steady $80-100$ knots, the wind gradually eased through 22 nd to a calm at
midni ght when the cached earlier relay loads were collected. 23 rd and 24 th each started well: First Ascents were made of "Father Peak" (3950ft) and "Mother Peak" (3800 ft) as cloud gale and the area each morning. Four more fester days on "Windy Col" followed, with a NE gale and spindrift, which later moderated to cloud and heavy snowfall. 16 days had passed
since leaving "Dayglo Point", with little achieved. However the large loads possible with I-man pulks allowed them to outlast the bad spell.

camp at 3500 tho still in cloud but calm, they pulked 5 miles around in heavy snow to cumperb weather, de Gerlache led the First between the Solvays and Mount Parry. On 30th, in been his grandfather's target in 1898. That evening Atkins located a coaxial-cable hefect with a sal lmakers needle and headtorch and repaired it: Lumsden made his first radio December began beautifully. After an al binealachn

perfect snow and at 0815 pitched camp on "Sol atun et" $(4200 \mathrm{ft}$ ) the pulked $4 \mathrm{miles}$ south on of the Solvays. That evening Lumsden on skis led the First Ascent of Red Rose Summi before. On 2 nd cloud stopped climbing, but L and also recelved a Rearlink message advis sing that second Summer plans were now based on the major pour days of superb weather with alpine starts then enabled First Ascents of all the major peaks in the Solvays. On 3rd Lumsden led up Galen Peak (5060 ft). On 4th Atkins
led the highest peak. in the range, named "Mount Frederick cook" (5280 ft). On 5 th the southwest ridge was traversed, partly in whiteout mak ing 6 first ascents culminating in the on the pulks in sunshine. Atkins recorded altimetry detalls to quantify map hel ght
errors of up to $1000 \mathrm{ft}$. (Se日 Survey Appendix). 
and Lumsden sth, Celsus peak proved the hardest climbing so far on the expeditione Atkins

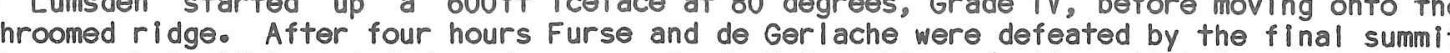
mushroom, but Atkins led Lumsden up a Grade $V$ ice chimney/gulley pitch to complete the band, and had a lifwayt "leader falli", half of it alrborne cartwheel of of a 60 degree below. Luckily the rope looped over a mushroom and the rope absorbed much of the impact before he hit the snow. He was bruised and shaken, but with no major injurles. They skied back four miles/1000 ft to the camp on "Solatunet", a Sunday. AThree days of cloud, snow and high winds then delayed departure. on 10 th they broke camp at 2300 and headed north. A cache of rock samples had

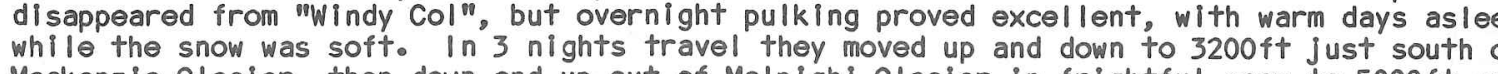
Mackenzie Glacler, then down and up out of Malpighi Glacier In frightful snow to $5000 \mathrm{ft}$, and a westerly gale stopped movement on the night of 13th, but in the morning of 14th the dropped don to camp at 3500 it on the pledmonto Leaving at 2300 that night, after pulking on 15th. Then it took another 8 hours to reach base camp in cloud due to unsafe crevasse bridge conditions. The whole journey from the Solvays to basecamp had taken just under $10,500 \mathrm{ft})$ and with light pulks, this was quite exceptional for overland travel on Brabant Island.

done outstanding very proud of, and close to Atkins, de Gerlache and Lumsden who had al done outstandingly well on the 45 day trip. Apart from checking the "Dayglo Point" cache, forcibly demonstrated the potentlal of I-man pulks for self-suporting trips of over 30 so long in the snow.

Basecamp. 12-28 December 1984. Whole teame except Evans.

sorting stores and clearing gash. Kimbrey began setting the two Avons and 5 oMc engines to hattiswood rigged moorings in the boat haven. on 14 th Ringe and Spottiswood pulked over to "Cairn Point" and carrled out a 3 Dayglo Party arrived on 15 th, Kimbrey took the boats out for their first run on 16 th, \& on last 2 months over sample bottles of whisky and rum in the hut. A radio message had been recelved from the Second Summer Party in Stanley.
station VPC had earlier stated they would listen out on $4067 \mathrm{KHz}$ every evening for the 3 Station VPC had earl ler stated they would Isten out on $4067 \mathrm{KHz}$ every evening for the questions unresolved, pending direct contact between the Winter Party and the Second Summer

Party as Endurance approachedo
Kimbrey, Beattie, Sportiswood \& Stuttard (\& others) laid a mooring in the sound, trip to claude point was repeatedly postponed in cloudy thawing weather, rain and swell. Beattie, Furse \& Stuttart progressed their Life sciences and everyone prepared stores for
the changeover. On 20th the whole team turned-to clearing gash and ditching it over the "Gash Gully" icecliffs on the south side of the point

Despite brighter weather the sea remalned livelyo. Finally on 24th Kimbrey to claude polnt. However they met heavy swell in the western skerries. Instead, Ringe, stuttard and others were landed on "Easter I sland" to explore it.

Christmas Day was enjoyed quietly, thinking of going home.

28th. A Two days had been allowed for final preparations ready for the changeover on contact was finally mado contact was finally made with Endurance, and it was learnt that the changeover would not
start until 29 the A good 3 hour radio on 28 th all lowed hurried arrangements by the two
parties before the changeover.

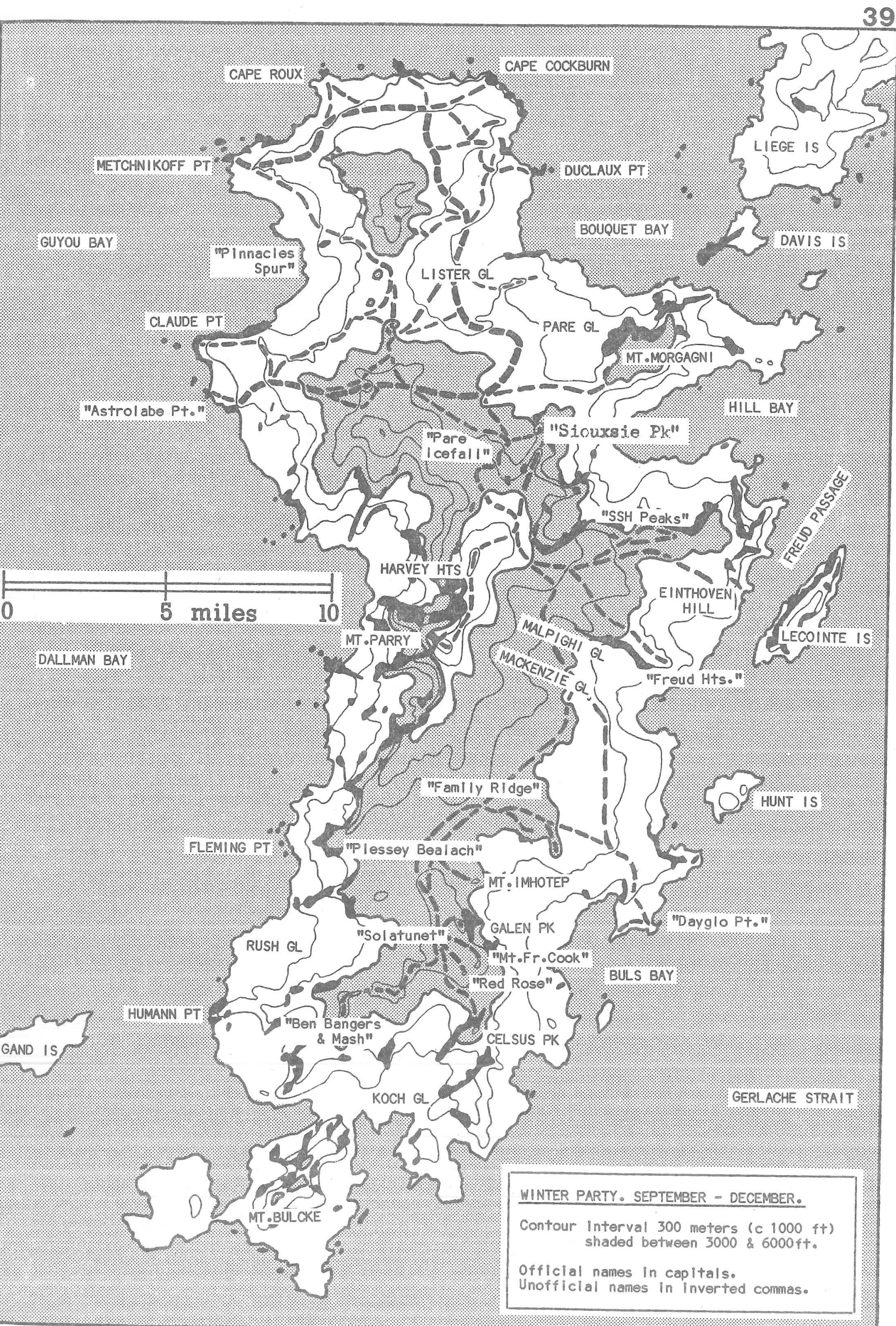



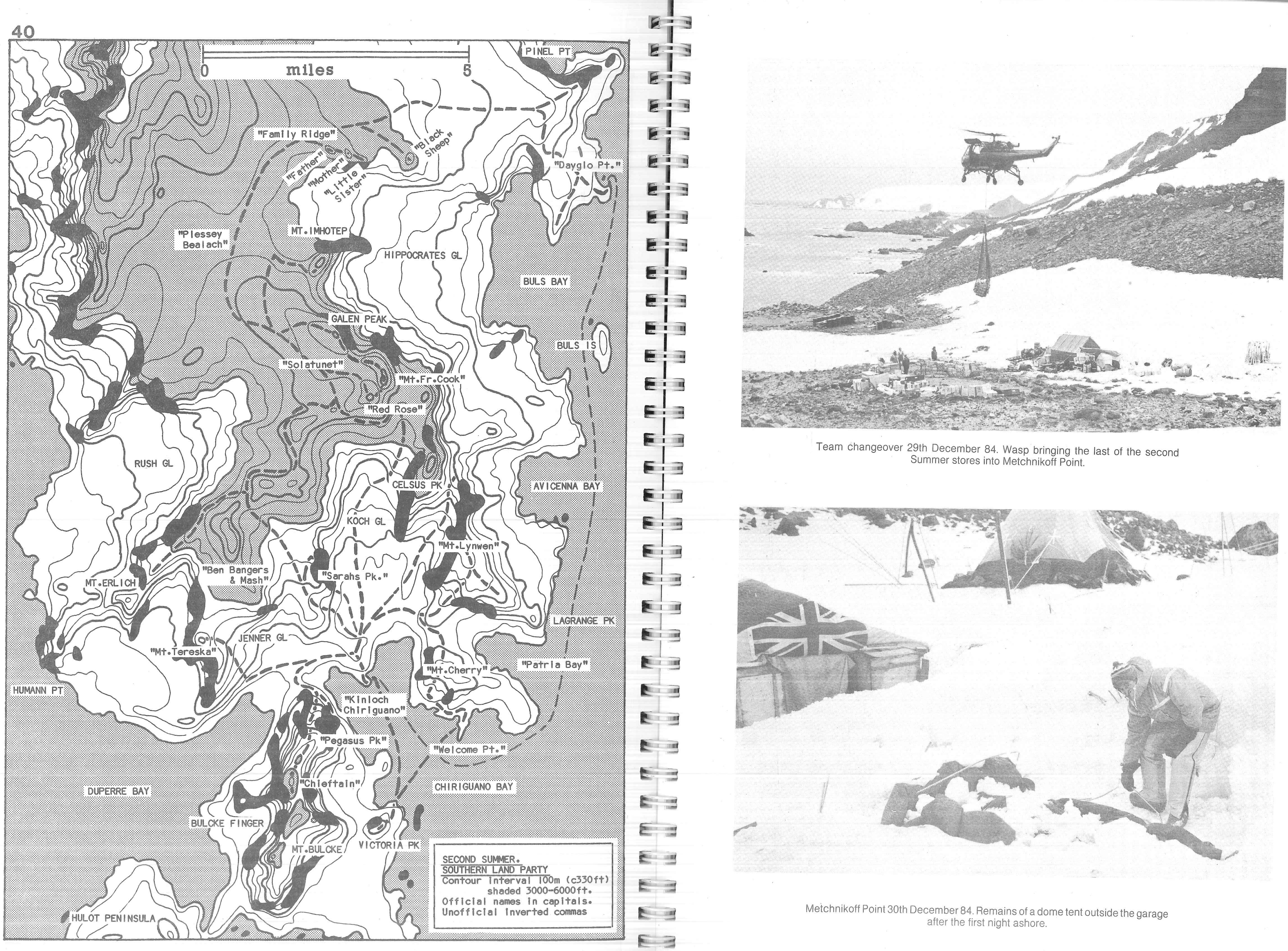

Team changeover 29th December 84. Wasp bringing the last of the second
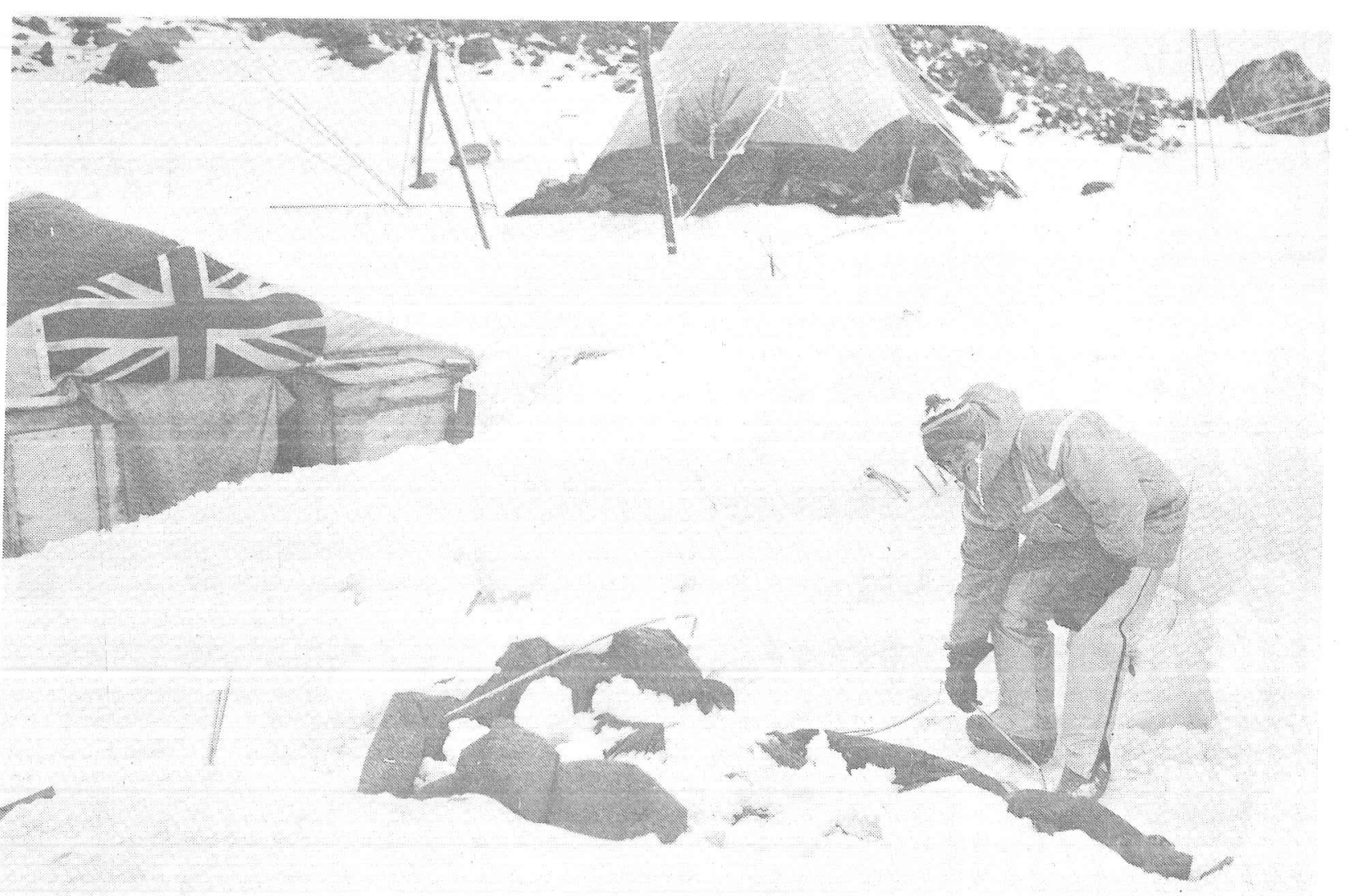


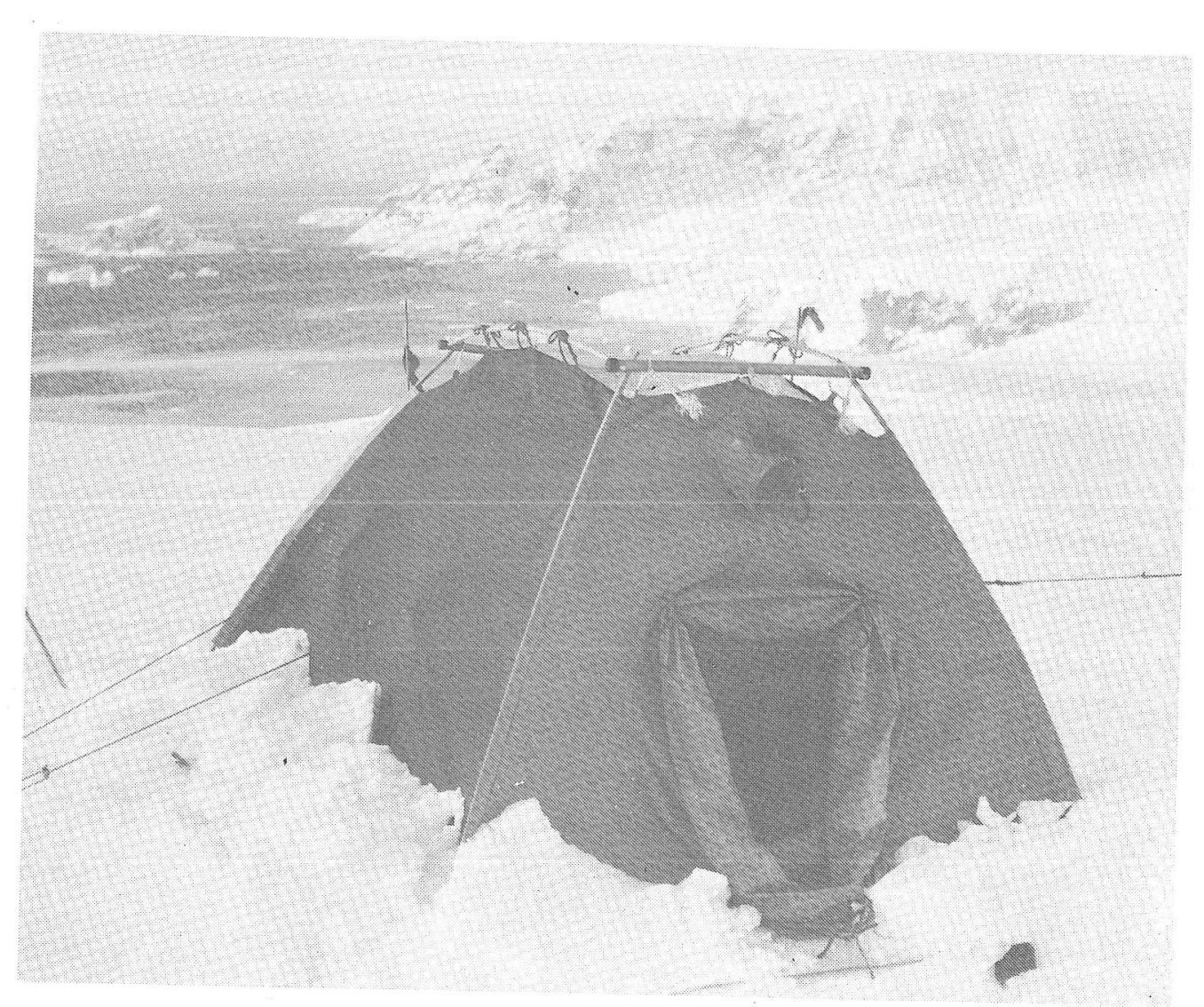

Conquest snowline box tent on Lister Glacier. Mount Morgagni beyond.

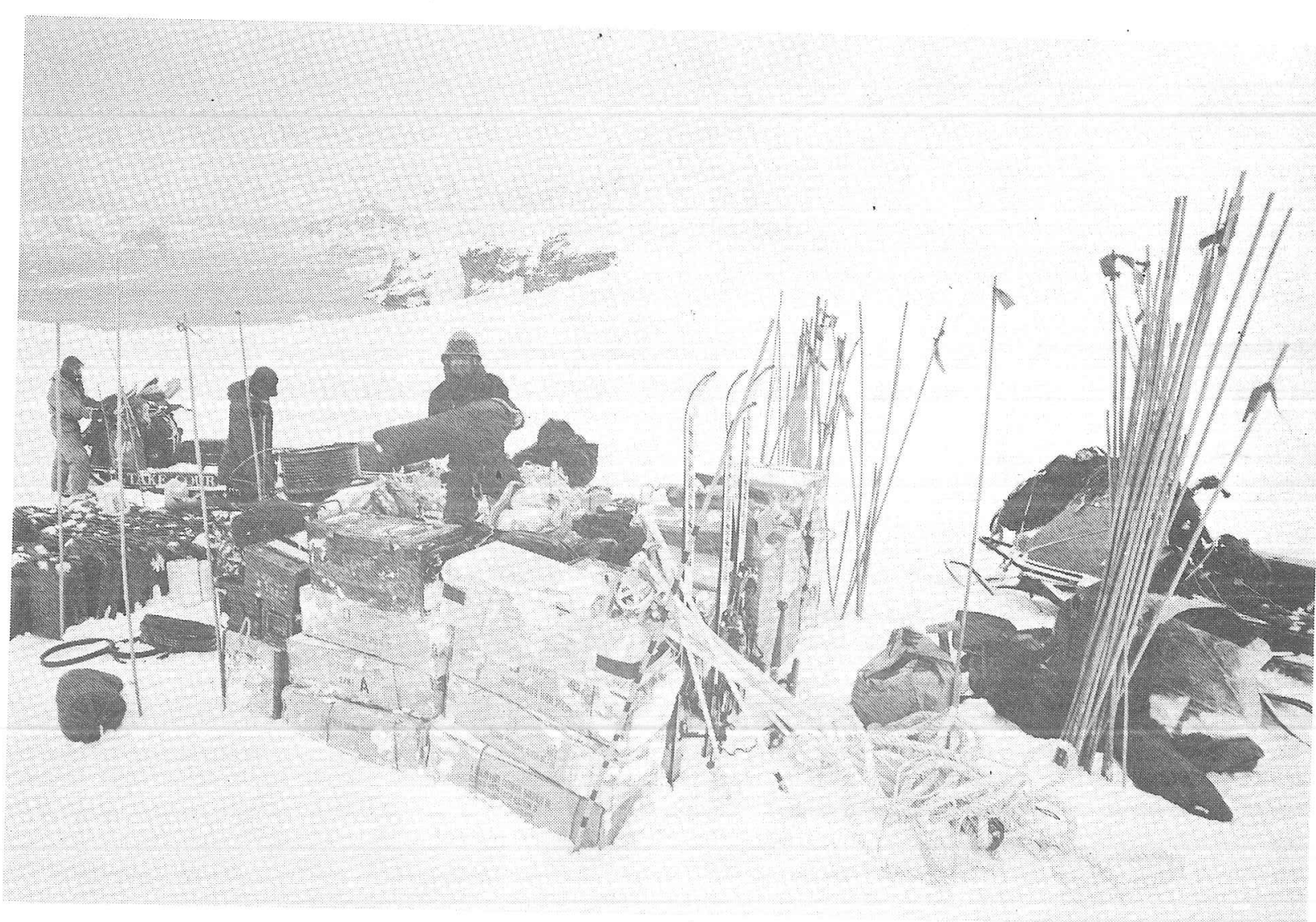

Skidoo party. Spottiswood, Atkins and Beattie on Lister Glacier with some of the

mountain of gear they moved in September.
0930 on 29 S Endurance hove in sight off Metchnikoff point out of fine weather haze at clements to coordinate stores. Through the day Waghorn's 7 man Boat and the second landed Metchnikoff Point with all their stores, and the Winter party stores and then team were embarked. Individual handovers were fever ishly progressed all day. Spottiswood, Atkins

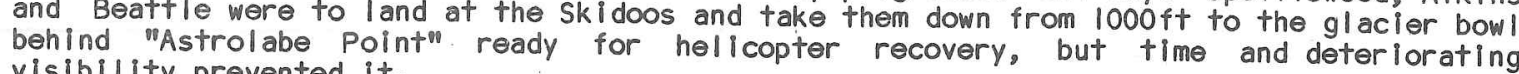

Overnight Endurance sailed through the Schollaert Channel. On 30th shifting low shifting low access rather broken, so Taylor decided to put his wase landed there and found the lceramp continuing poor visility, stores were flown into "Dayglo" and a large cache of food and point". After flying had finished Endurance entered Chiriguano Bay to enable a binocular

stores Overnight Endurance sal led back to arrive off "Astrolabe Point", ready to move coast. Low cloud and falling snolnt, and to attempt to establish caches down the west plans to recover the skidoos direct from $1000 \mathrm{ft}$ were shelved and also the move to Metchnikoff Point. A hydraullic fallure then grounded one Wasp for the whole day. Ali stores were recovered from "Astrolabe Point" itself, and a cache of food flown onto Claude
Point, together with the stores intended for Metchnikoff Point Cloudbase varied through the day, never rising above $2500 \mathrm{ft}$, but with the two Aircrews alternating in the serviceable Wasp, a remarkable day's work was completed. Working southward, each wingt the point was first reconnol tred by Furse, and then 2 Winter Party team members were landed to Point, Fleming Polnt. Humann Point and the north coast Endurance returned into Gerlache Strait: a fairly suitable site on the east side sit guano Bay was found, and another cache landed there. Several additional boat landing sites were also identifled around the south coast. Endurance then departed north for
Trinity Island.
E

E

E i1

E

E

E

E

E

E

E

EN

E

$=$

E

E

E

$E$

E

$E=$ 
"Davglo Point", 30 December 84 to 10 January 85. Whole party.

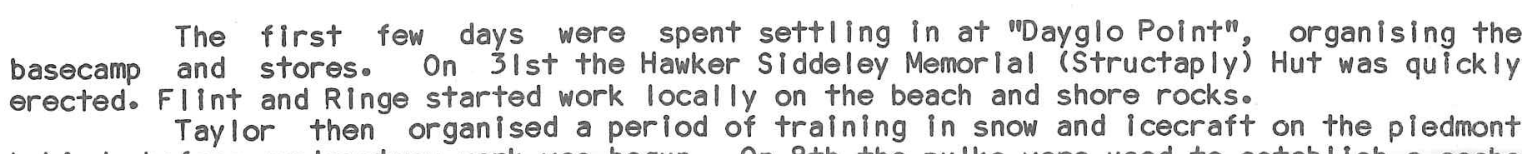

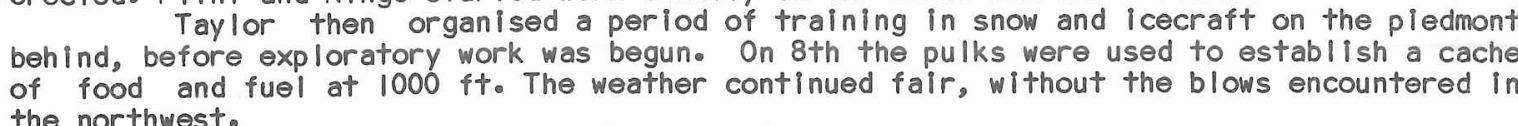
the northwesto 0 th they left in three 3 -man partles with nine 1 -man pulks, travelling
together, to camp at midnight above Pinel pointo The plan had been for three to travel south

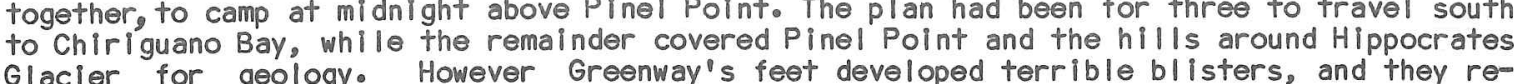

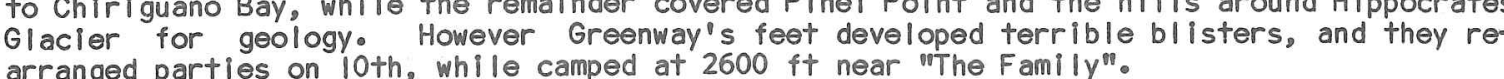

Chirl guano Cache Reconnaissance Party. 11-15 January 85. Taylor, Ball, Lawrencee

On 11 th they pulked on up and around to camp above Rush Glacier enjoying a
magniflcent sunset. Next day they reached the ridge at $4300 \mathrm{ft}$ overl look Ing Koch Glacier in poor visibility, where they were holed up for two days in northerly gales and heav snow. When the weather cleared on 15 th, the avalanche risk was too great down into Koch Glacier and they did not have enough kerosene to walit, so they cached the three pulks
ratlons on the ridge and returned to "Dayglo Point", sighting Endurance heading northo

"Famlly Ridge" Scientiflc Partyo 11-14 January 85 Ringe, Barker, Martin.

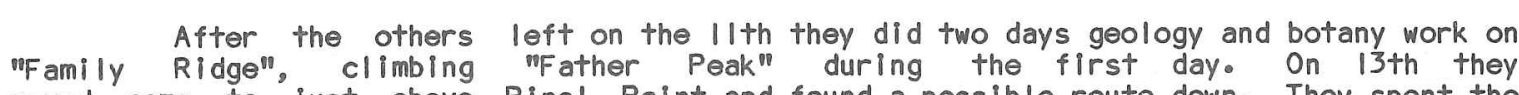

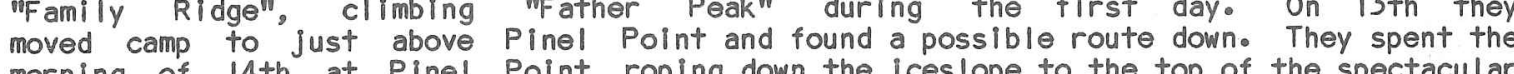
morning of 14 th at pinel point roping down the iceslope to the top of the spectacular

\section{"Dayglo Point". 11-14 January 85. Greenway, Allen, Fllnt}

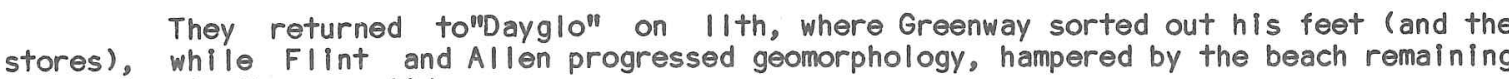
stores, while
underwater in the neap tides.

"Dayglo Point". 15-16 January 85. Whole Party.

Ringe \& Martin catalogued samples on 15 tho. Tay lor's party arrived at midnight

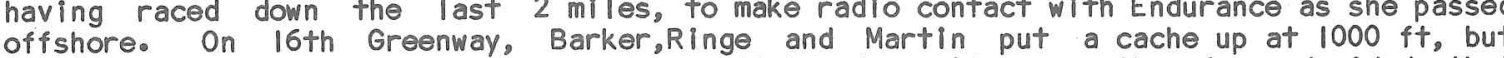
Greennay's feet were agaln badly bilsteredo. It was therefore decided that
Ball would remaln with Greenway while the other 7 headed southo. For several days there had Ball would remaln with Greenway while the
been no radio contact with the boat party.

Journey South. 17-30 January 85. Taylor, Allen, Barker, Flint, Lawrence, Martin, Ringee On 17 th, after a mornings geomorphology, they took 6 pulks up to their prevlous
campsite at $2600 \mathrm{ft}$ below "The Famlly", and cont Inued next day to the head of Rush Glacier In excer lent weather ridge tents. That evening the wind strengrthed to 50 knots, with gusts reach ing about 90 knots, threatening the entso Two laden pulks were blown past a tent, and one of them went
100 yards downslope toward Koch Glacler. For three days dense cloud and fall ing snow prevented movement, but it cleared

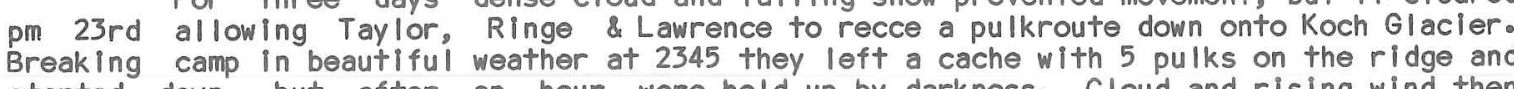
started down, but after, an hour were held up by darkness. Cloud and rising wind then
forced them to pitch camp, turning in at 0630 . Throe days whiteout fol lowed, with the party on half rations. "The Tent" was very
wet and a pole broke. On the evening of 27 th the weather suddenly cleareds they struck

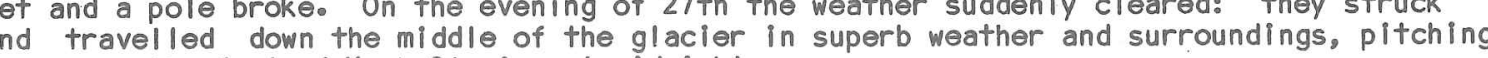

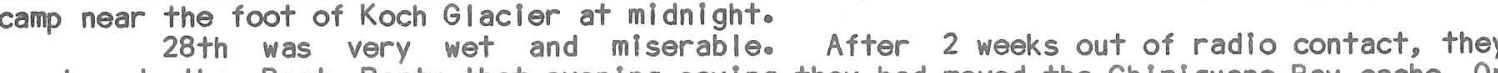
overheard the Boat Party that evening saying they had moved the Chiri guano Bay cache. On

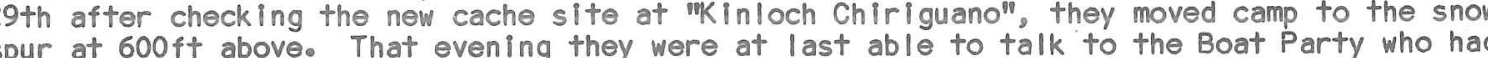
reached "Dayglo point" o The Boat Party came to "Kinl och Chiri guano" next morning, bringing
"Dayglo Point"1. 17-29 January 85. Ball, Greenway.

After the rest departed the two continued varlous local work; Greenway found small colony of Shags on mayglo" that Furse and others had missedo
On 25 th a storm threatened the hut and stores. While doubling up hut-lashings Greenway slipped, and a full drum of fuel crushed his knee agalnst a rock with a crack.
He was virtually immobillsed, and Ball helped him into the hut, where he slept painfully on a bed of food boxes, nursed by Ball. On 27 th the Boat Party arrived out of the blue, and Will lams treated Greenway.
on 30 th the boats took Ball to mKinloch Chiriguano" and then returned. That night they On 30 th the boats took Ball to min inloch Chiriguano" and then returnedo. That night they
ferried Greenwy out to the MV Polar Duke, bitterly disappolnted but resigned, as he
was still immobile (later he was found to have fractured his right tibla).

\section{Southern Base Campo 30 January -2 February 85. Taylor, Allen, Ball, Barker, Flint
Laurence, Mart In, Ringe, Will liamso ( $=$ Whole Remaining Partyy.}

With the whole party (except Greenway) united again, preparations and plans were
for exploration of the south endo Food and fuel were brought up from the "kin inloch completed for exploration of the south endo Food and fuel were brought up from the " Mn inloch

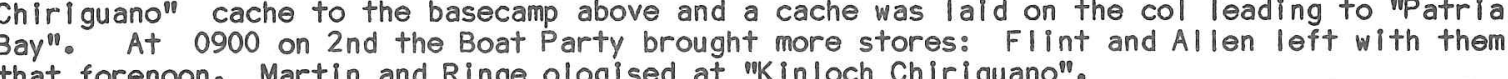
that forenoon. Martin and Ringe ologised at "Kinloch Chiriguano".

Cllmbing Party. 2-12 February 1985. Taylor, Ball, Lawrence.

They left in the evening of 2nd and camped by the cache on the col between Koch
Glacier and upatria Bay". Next morning they made the first ascent of uMount Lynwen" and traversed the ridge, largely on skiso. Returning past their camp they also climbed the Fidge between "Patria" and Chiriguano Bays, then in rapidly deterlorating weather returned After 2 days with Taylor suffering an eye infection (or snow blindness) and
another held up by broken cloud, they moved west on 7 th to camp on the bealach north of On 8th, cloud and falling snow prevented an attempt on Mount Erlich, but they made the first ascent of the $3000 \mathrm{ft}$ twin peak on the SW ridge of the Solvays, before
returning to the basecamp above "Kinloch Chiriguano". They stayed there, largely in cloud, the pro-arrasged rendezvous on 12 tho

Koch Glacier Scientific Party. 2-9 February 85. Ringe, Barker, Martin.

northern The first 2 days were spent on geology and invertebrate collecting around the returning to then made a 0200 . On 6 th they and rock ascent of the southern peak on the ridge, returning to camp at 0200 . On 6 th they moved up the Koch Glacier to work for 3 days on
the exposures there before returning to basecamp on the evening of 8 th, after a very windy
day. After one night camped there with Taylor's party, they moved to "Welcome Point".

Geomorphology Party. 2-9 February 85. Flint \& Allen.

Leaving by boat on 2 nd they made the first ascent of Victorla Peak with the Boat Party before being landed at "Wel come Point"o Together they began survey and studies of
the Intertidal beaches each side of "Welcome Point", though the neap tides severely limited access.

"Welcome Point"。 9-12 February 85. Ringe, Allen, Barker, Flint, Martin.

Weather was poor on 10 th but geology, geomorphology and invertebrate work was progressed on "We lcome Point" and the small
rejol ned Tay lor's party at the basecamp.

Southern Base Camp. 12-18 February 85. Whole Remaining Party.

On 12 th the Boat Party were contacted by radio and arrangements made for Flint
and Martin to be picked up on 14 th and taken to Minot Point for sclentlif ic work. Two days of mixed weather were spent on the ridges to north and west of the camp, before learning on 14 th that the boats had suffered various troubles preventing them collecting Flint northern peak but were then stopped by a difficult icestep, and storm foree windso. Back
at the used for photography and planning the next week.
usecamp they learnt that the boats had 
44

Exploration Party. 18-26 February 85. Taylor, Barker, Flint, Martine

They planned to visit the Hulot Peninsula and set off in glorious weather on
18the They were unable to force a route round the steep and broken northeast slopes of Mount Bulcke. After camp Ing one night among the crevasses there, and trying again next day
they returned to the basecamp. they returned After a day spent repalring skis etc. they set off on the 21 st hoping to climb route up to the solvays ridge east of "Ban Bangers \& Mashn weather they reconnoltred not windso In poor visibility, next day Martin and Tay lor clímbed "Sarahs Peak" beck 50 Ben Bangers and Mesn onto half rations on 25 th. In glorious weather on the 26 th they had a magnificent ski down

Scientific Party. 18-26 February 85. Ringe, Allen, Ball, Lawrence.

On 18 th they went to "Welcome Point", visiting en route the SW end of the rock cliffs of "Mount Lynwen". Five userul days were spent at "Welcome Polnt" and local areas, enjoyed a magnificent display by whales close inshore.
On 24th they completed the work in por Mountain tent on the col between Chiriguano \& upatrianBays. Next day, after collecting geological samples near the col, they returned to the basecamp, with Bail testing Ringe's
iceaxe arrests on skis. The others jolned them on 26th.

Mount Bulcke. 26-28 February 85. Whole Remaining Party.

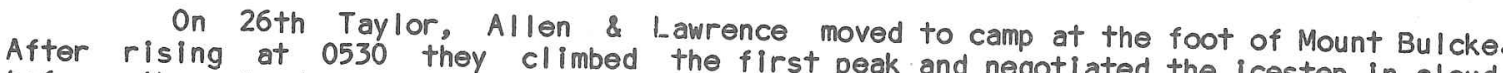
before the cloud evaporated suddenly to give fantastic views. They reached the cloud feet, which climbing another of the northern peaks of this spectacular mountain before returning to
base camp. The other five spent the two days on geology and photography at the north end of
Mount Bulcke. On 28th the basecamp area

East Coast Party。 1-6 March 85. Ringe, Flint, Martin.

the col They planned to return to "Dayglo" via Avicenna and Buls Bay. However on reaching Bay barred by a steep, heavily crevassed slope. They returned to the basecamp for two
nights. On 3 rd they moved up to the head of Koch Glacier before very strong winds
stopped themo. Next day they ascended to the Solvays ridge at $4300 \mathrm{ft}$ finding the cache and high winds party below Galen Peak, then continuing in bad visibility to reach "Dayglo meoting Taylor's

High Level Party, 1-9 March 85. Taylor, Allen, Ball, Barker, Lawrence.

Leaving the southern basecamp on Ist with 2 pulks they had a very hard day
loads up Jenner Glacler in cloud to camp (still in ridge east of "Ben Bangers and Mash". Next day they sk ied cloud) at $4000 \mathrm{ft}$ on the Solvays an attempt on Mount Erlich, but at $2500 \mathrm{ft}$ it became obvious that it could the ridge for On 3rd, in beautifur sunshine but gale force northerly winds they traversed the ridge to the $4300 \mathrm{ft}$ cache, where they picked up 3 more pulks plus rations and fuel and
continued to camp NW of Galen Peak, at $4000 \mathrm{ft}$. After 2 hours they pitched foll lowing day. On 6 th in good weather they continued, to arrive at "Dayglo Point" in the evening, a few hours before the East Coast Party arrivedo.
Taylor, Allen \& Lawrence broke camp on 4 th, climbed Mt.l Imhotep in cloud and camped nearer Galen Peak. After a day of cloud they climbed Galen Pak, "Mount Frederick
cook" and "Red Rose summit" on 6 th in

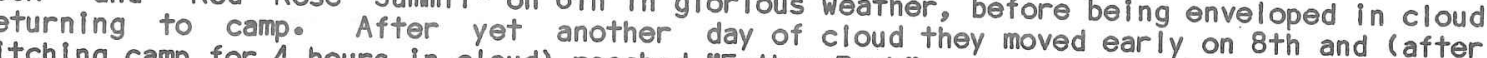
pitching camp for 4 hours in cloud), reached "Father Peak" and camped nearby in cloud againo
On 9 th they cllmbed "Mother Peak" and made the first ascent of "Little Sister Peak", Reaching "Dayglo Point" that evening they learnt of great events that had been

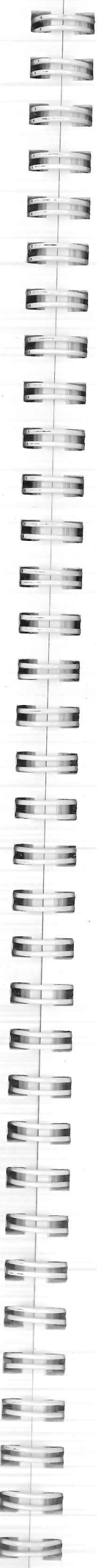

E

E

E 3

E

E.

E

E

E

E

E

E 3

E

- 3

- I

- 3

E

E. 3

E:

E:

E

E:

E:

19

更

$E=$

$E=$

$=$

$=3$

$=3$

$E: 3$

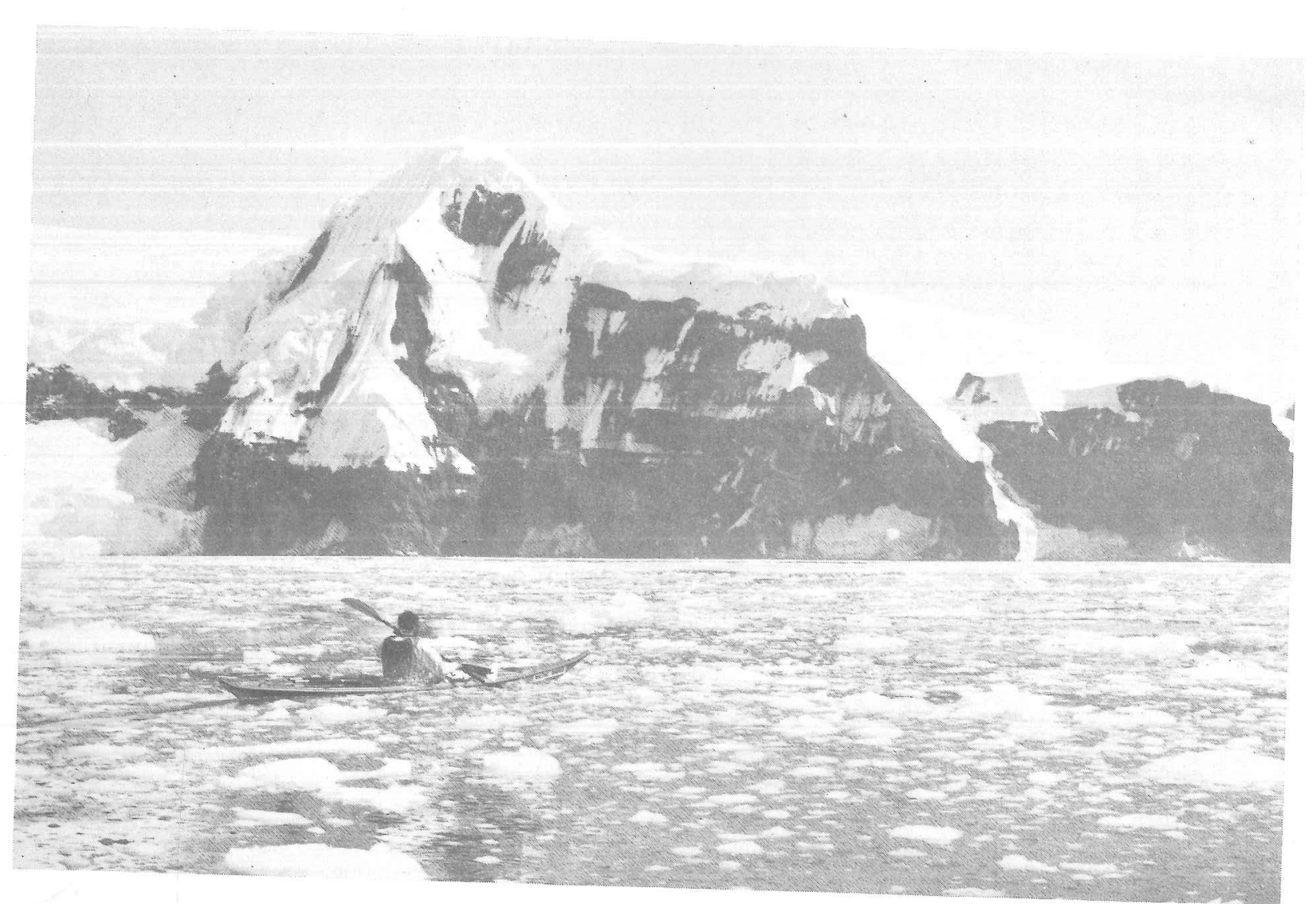

Waghorn paddling through brash ice off East coast.

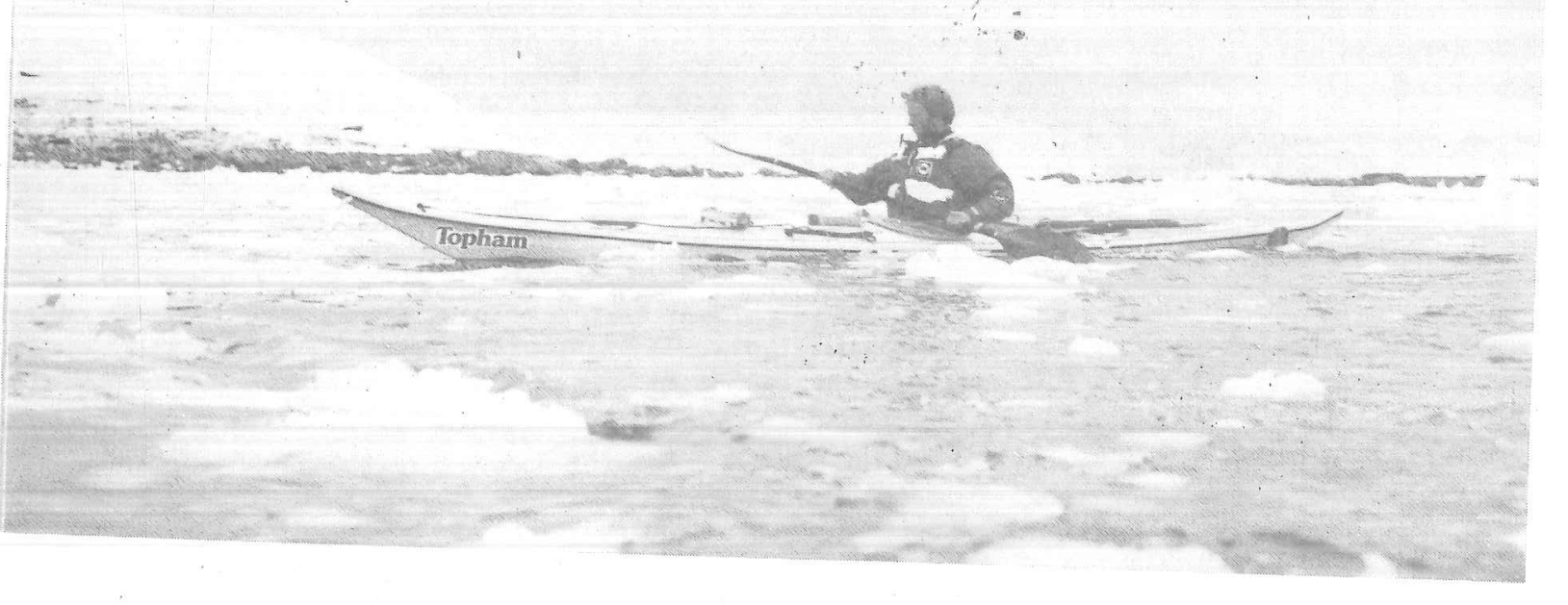

Clements paddling off typical South East coast spit. 


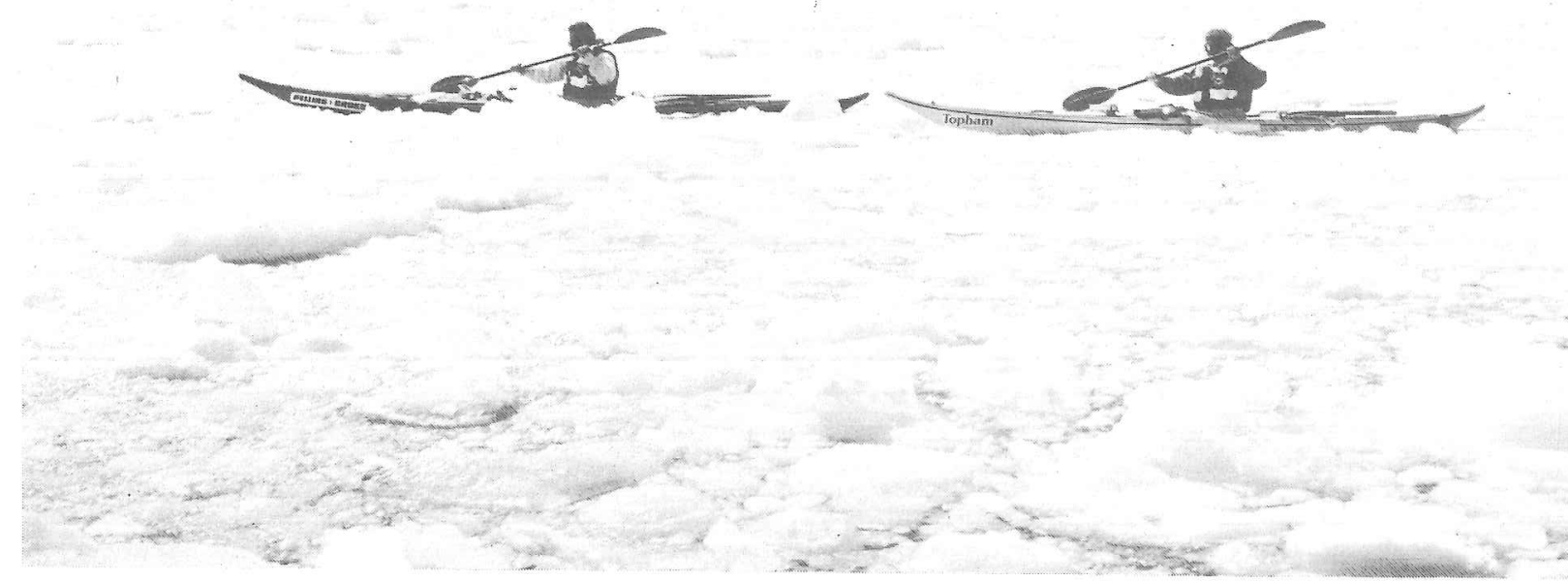

Circumnavigation in February 85. Waghorn and Clements in brash in Bouquet

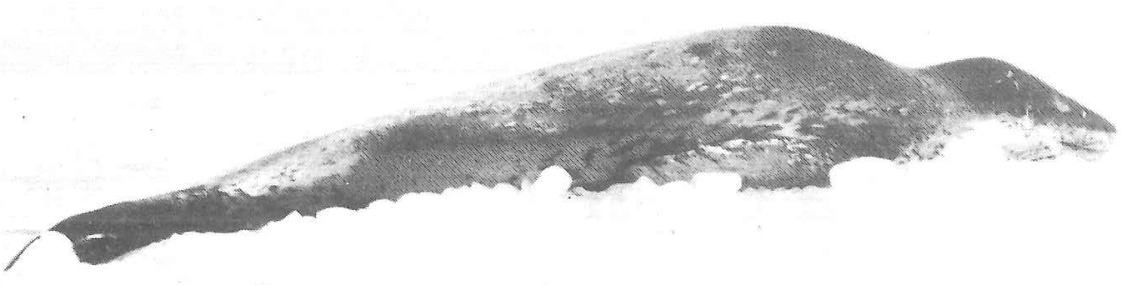

Leopard seal from the boats, in Bouquet Bay, February 85

Shakedown Period. 29 December 1984 - 15 January 1985. Whole Party.

On the first night 60 knot winds and drifting wet snow coll lapsed one Super Nova
tent, a dramatic introduction to Antarctica for the 3 occupantso

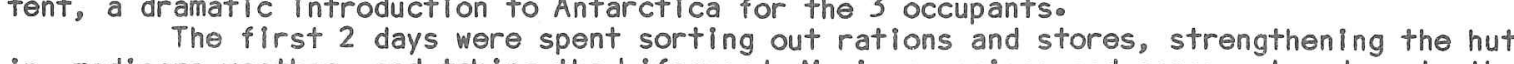
in medlocre weather, and taking the L L feguard, Mariner engines and canoes etc. down to the
boat haven. On New Years Day the Lifeguard was commissioned with a full power trial and do Radio contact was mado claude point in two boats landing in a cove near the penguin colony. While the others ologised, Waghorn, Clements and Moffat attempted to reach the cache, but were stopped by loose rock where the gully reached the foot of the the teeth of a rising gale, with winds over 60 knots as they came through the stacks of Metchn koff polnt.

commissioned the canoes and

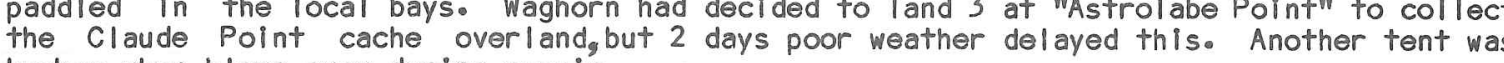
broken when blown away during repair.
On $7+h$ Clements, Gill and Moffatt were landed by boat on "Astrolabe Point", in partial shelter from the swell on the northern rockshelf. The others revisited claude
Point for further ologising; after being swamped as they left the beach they reconnol tred around Guyou Bay and returned to Metchnikoff Point. Clements, Gill and Moffat reached Claude Point, but on 8th their tent poles were
broken by gale force winds and they spent 24 hours propping the tent up bodily. At
Motchnikoff the rising gale capsized the Avon moored in the boat haven: the boat was righted and engines recovered and given first aldo Next day in poor weather they righted
the Avon, which had capsized again, baled out the Lifeguard, improved the mooring arrangements and stripped, overhauled and successfully tested the two swamped oMC engines. Despite wind and snow early on, the other three returned to "Astrolabe Point", with heavy attempt On 10th two boats went to collect the party from "Astrolabe Point". The first the boulder beach under, the northern icecliffs. Desplte a broken engine clamp, Hall cameras were soaked, but crewman Waghorn much impressed by Hall's sangfrold. After lunch in the bay, to let the thde rlso, They triled at a polint here the swell was not breaking best moments as the waves swept through. Once safely embarked with all stores they returned quickly to basecamp. Duclaux. Point, landing and collecting rock samples there. Coming back, no landing sites were found until Cape Roux, where they stopped for tea and ologies, before returning via
"Cairn Point" and other beaches to reach basecamp late that evening. "Compare 9-24 April Another good day on the 12 th was exploited to reconnoitre by boat down to
the beach and cache at Driencourt Point. The next three days were spent preparing for the circumnavisating clements caught the first fish by trammel net, and preserved several. been progressed. Altogether a great deal had been achieved in just two weeks.

Circumnavigation of Brabant Island, First Halfo 16-27 January 1985. Whole Partye

and loading brilliant day on 16 th heralded the starto. After securing the campsite in the afternoon the paddle across Guyou Bay in bright sunshing and boatingo setting of The canoeists landed at Claude Point, to eat and recount Chinstraps and Shags, before paddling on past Astrol abe Needle to Driencourt Point. Hall and Clements laid the trammel
net while the others pitched came 17 th was devoted to

to sclence. Waghorn, Gill and Williams canoed out to count all. Clements a Waghorn also visited Minot Point locating a possible boat mooringed bugs. inflatables made an uneventful 4 mile crossing to Minot Point. However, unloas and the 2 head of the best of the deep narrow inlets was difflcult, as the swell created large break ing. Waves that swept the boats backwards and forwards and periodically swamped themo feature of the terrain. A hot afternoon turned into a beautiful evening as the sun set verdant with many nesting Skuas and Kelp Gulls. Hall, Clements and Gill laid the thas amgly net and dropped Waghorn to explore the largest offshire islet, then motored of fshore to photograph a large lceberg drifting slowly north: when half a mile off, it capsized and
big waves reached theme Later Clements \& Hall climbed the major peak of the point (about $01 \mathrm{~g}$ waves reached themo Later Clements \& Hall climbed the major peak of the pos
$1700 \mathrm{ft}$ ), and Waghorn (in muk luks) climbed the minor one while counting Skua nests. 


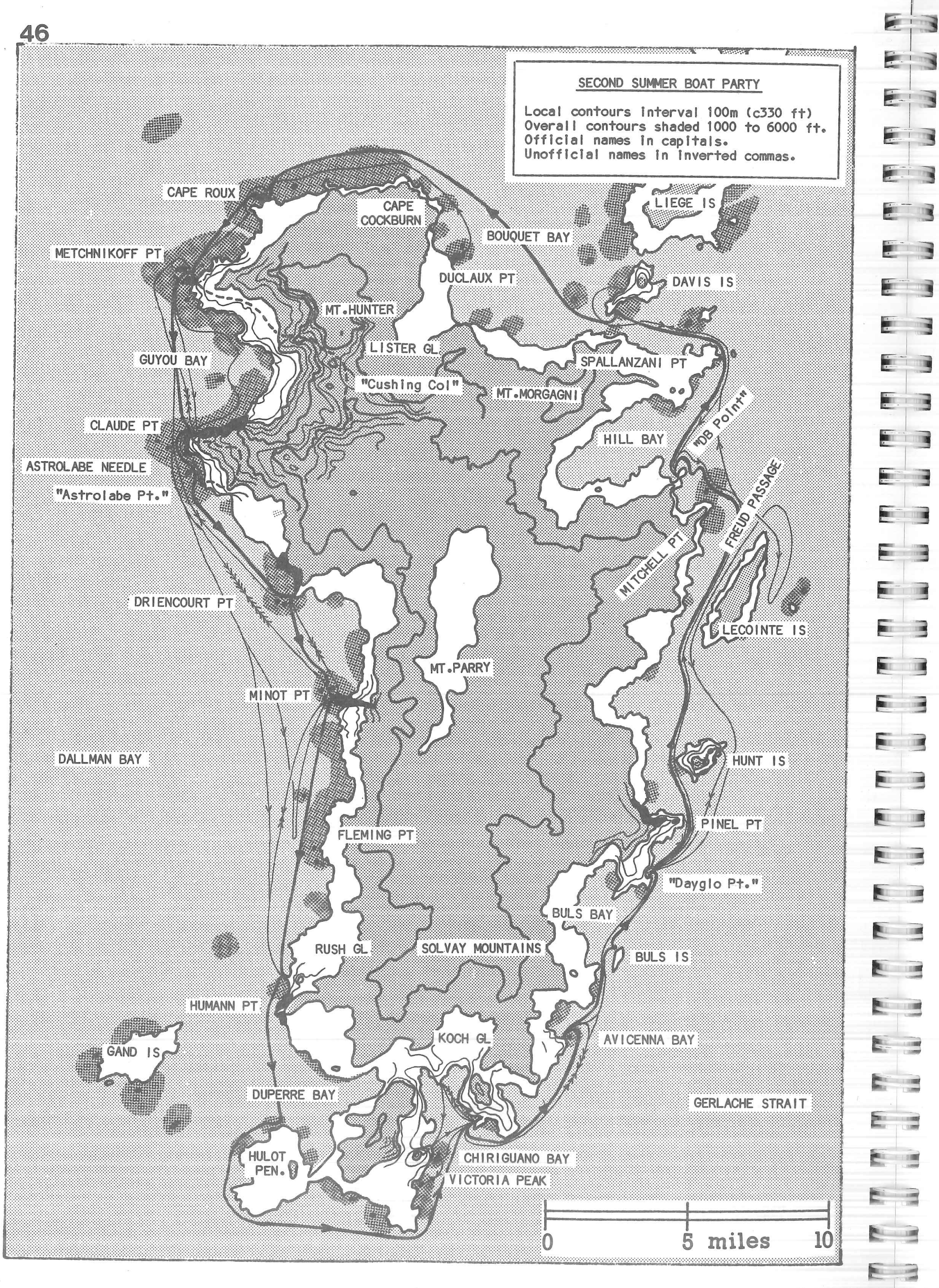

on 20tho Carrying the gear over the difficult rocky spurs to the boats slowed up departure

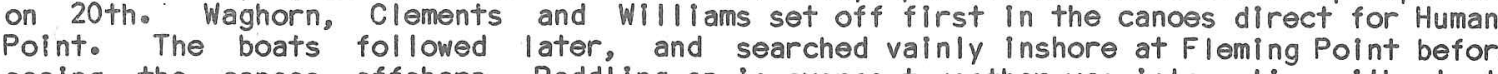
seelng the canoes of fshore. Paddi ing on In overcast weather was interesting, with plenty

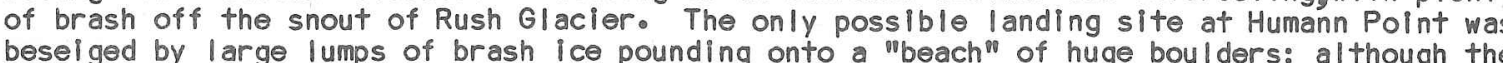
canoes could have landed it would have been dangerous for the inflatables, with an enormusly difficult pull out to foll lowo As it was getting late, the canoess were loaded on Peninsula, reported by radio by Furse, was not found, and the boats moved west around to icecllffs, then headed for Chirlguano Bay, as the easy landing sites reported there were no further than the way back to Minot Point. The swell in Dal Iman Bay was replaced by a In the heavily laden boats, and anxilety rose as the furel tanks omptiled, since refurelling would have been difficult in those conditions. However they reached "Wel come Point", got warm hauling the boats out, and camped on the Icy slope behind.

The 21 st was a well-earnt rest day, dry ing out in breezy sunshine and exploring
"Wel come Point". Next day, whil le Hughes and will lams ologlsed, Cilements, Hall and Mof fat lald the trammel net and then made the first ascent of "Mount Cherry" above "Welcoma

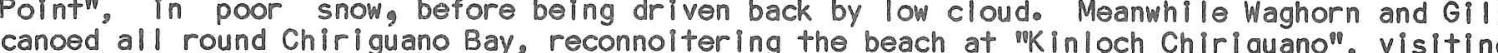
several is liets, counting birds and seals, and coll lecting botanical samples. While Waghorn corlected wingless mildges, ani collected hils canos which had drifted away; then the paddled back

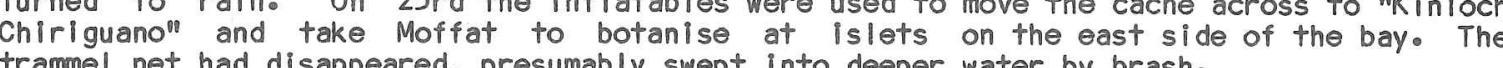
Having lost, radio contact with the southern party for 2 weeks they deci ded to
continue to "Dayglo Point", rather than return to Humann Point Just to paddle that 14 mil les. Mountain tents stood up well to strong gusts, despite standing on plnnacles of Ice with water running pasto

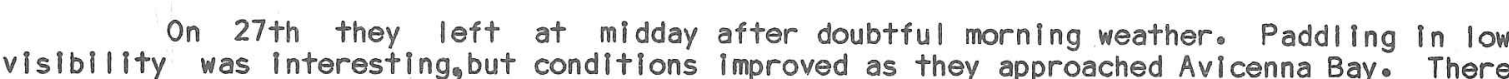
they found the cache had been scattered by falls off the Icecliffs behindo. The canoeists paddled to the island to count shags and kelp pull s, and laughed at the others as the Avo

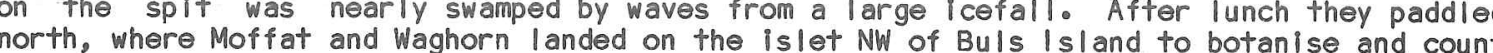
Shagss North of Buls island paddling was awkward before a southerly wind increas ing to Force $4 / 50^{\circ}$ in the confused sea off the north end of Buls Bay, Clements caps ized, but
rolled up well at the first attempt, the first roll in angero They arrived at nDayglo

Circumnavigation of Brabant Island, Half TIme. 27 January-3 February 1985. Whole Party. On arrival at "Dayglo Point" the Boat party found Ball nursing Greenway in the

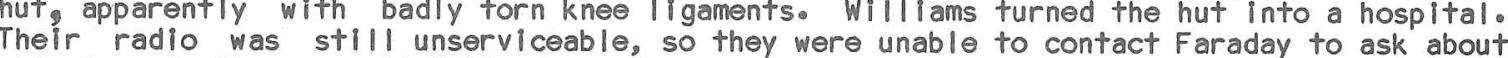
shipping in the area. At 2100 , deus ex machina, a ship was sighted offshore heading north.

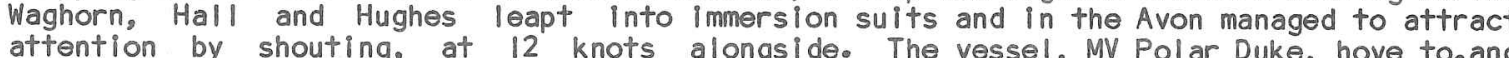
attention by shout ing, at 12 knots alongsideo. The vessel, MV Polar Duke, hove to, and
Waghorn negot lated evacuatlon of Greenway when the ship was noxt due to pass (on 30 th), and

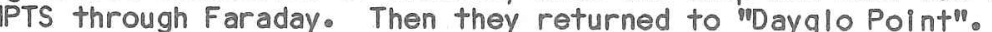

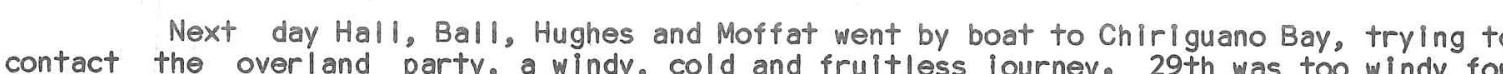

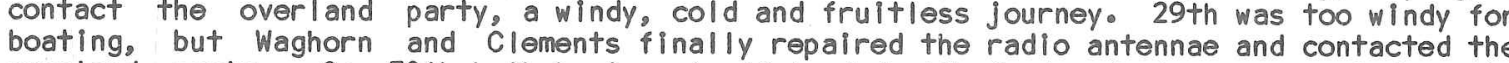
overl and party. on 30 th both boats set off folloaded with food and stores requested on the

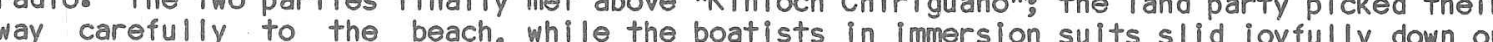

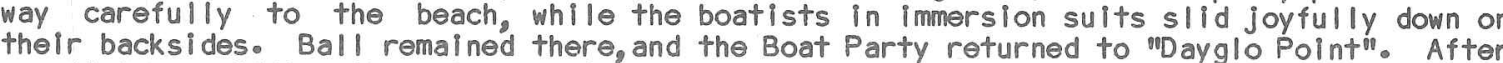

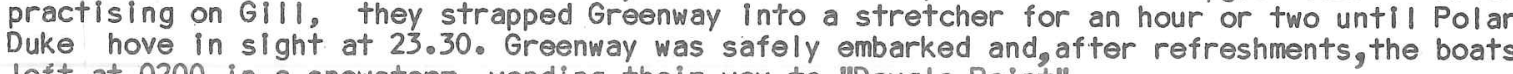

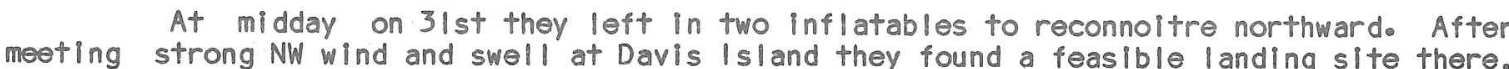
then $a$ better one just west of Mitchell Pointe There was no landing ln Freud Passagere, around the north end of Lecointe Is land. A Shag colony and possible Jump-landing was found at Hunt island. They returned to "Dayglo" affer a useful 50 mil le day on one 5 -gallon fue fank 

Chiriguano" A Allen and Flint Jo ned the boats: they landed below Victorla Peak. Waghorn. of this fine pyramidical peak up the eastern arete and returned to the boats. Clements, Waghorn watching as one man alone searched a a levalanche cone for a stuff-sack knocked off Clements "rucksack by a falling rock. Allen \& Flint were landed at "Welcome Point", and the
boat party returned to "Dayglon after another long successful day. When the weather cleared on $3 \mathrm{rd}$, Clements, Hall and GIII were ferried to Hunt
Island, Jumping off onto an impressive ICy face. One Mariner propeller shearbush sheared as Hughes returned to "Dayglo". The other four then went to Hunt I sland by boat to
ologise. The Lifeguard was hauled out making launching difficult. The three had to "Dayglo" in two trips, with a bitingly cold wind and sea. After a late supper returned

Circumnavigation of Brabant |s sland. Second Half. 4-5 February 1985. Whole Party.

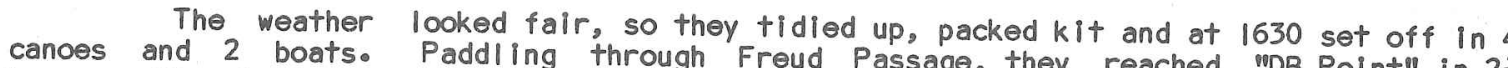
hours. The boats were hauled out, and a chunk of the ice arete knocked down and levelled
into a shelf where they bivouaced in a rowg in sleeping bags and goretex bivvi bags, two

At 0600 the sun woke those on the east side of the arete, while hoar frost still lay thick on the two west-side pulk beds. Hughes observed many Snow Petrels around and reaching the cobble beach on Davis Island for a brew at 1030. As they pasdlill Bay Bouquet Bay, the largest of the grounded bergs capsized in an amazing display. Thic brolling sunshine, nudging up uclaux Point, and they headed straight for Cape Cockburn in Cape Cockburn the ice thinned out in the big swell swerping in from the Bellingshausen Sea soon they were battling into a Force 4 wind and sea, with the swell reflected off the glacler cream off their faces. After 18 miles of paddi ing GIll and will spray washing the lifeguardo Slowly Cape Cockburn slipped astern and Cape Roux came closer. The got into the the narrow channels, landing to let Gill and will lams put on more clothes, but were inflatables then went round the outside, but Waghorn and Clements waves swept by. The paddled through the 2 yard channel between the cliffs: big surf waves were washing to an ro as both successfully shot through with Fur Seals porpoising across their bows. It was over the next 200 yards, half an hour to battle through an amazing scene of "clapotis" stopping, and an hour later everyone was home - exhausted and cold, but in slated, there was no
s. Waghorn and Clements had paddled the whole way round (except the 14 miles from
Humann Point to Chiriguano Bay), while Gill, Moffat and Will rams had alternated in the of canoes. The last day had been 26 ml les paddling in 9 hours, the last 17 mil les nonstop into
some poor conditions. It was a weary but proud team who pitched tents that night.

Metchnikoff Point. 6-11 February 1985. Whole Partye

The weather was generally bad, but a lot of making and mending was progressed.
Clements fished, and Moffat and Waghorn ologised on Easter Island. They prepared to put West Coast Boat Party。 12-27 February 1985. Whole Party。 On 12 th in better weather, although still rough seas, Moffat and Willilams were
ferried to Minot point, and extra food was transferred there from Driencourt Poilnto
Arrangements were made by radio to collect Martin and Flint on 14 th, from the Minot Point
campo camp. Next day Waghorn, Clements and Gill were ferried to Humann Point, landing with on a rock ledge. They camped a 11 title above, besing a rocky spur pon Rush and kit were landed and Hughes took the boats back to Minot Point. That night huge breaking swellis capsized On 13 th Hall and Williams fetched the Humann Point team, who broke camp and
returned with them, in a well-laden boat with one engine, into the teeth of a snowstormo Waghoguard, but Point in the Avon to repair the damaged engine and get spare engines, while the other 5
camped at Minot Point.

Next day Hall and Gill returned in the Avon, with two working engines plus one for
the Liseguard. Leaving Moffat and Williams at MInot Point, the other flve took the twe boats back to Metchnikoff Point. Hall \& Waghorn top-overhauled the one remaining swamped
Mariner and the damaged OMC outboard. finishing am 15 the Point in At midday the five of them set off from Metchnikoff Point heading for Human suffered three gearbox fallures in rapid succession. One boat with the on reint, the boats were emptied and everything got clear of the wet by a leering Leopard Seal. Both
the pickup of Martin and Flint cancelled by radio. On 16th, Waghorn and Hall strippor al

the remaining spareventing cannibalisation. Waghorn and Hall then set find identical ahead and into Metchnlkoff Pol They had a very rough passage, particularly off claud fotch defective englnes and put the Mariner on the Avon. Using the Mariner out of various Mariner propeller blades were bent durinding in the swell was extremely difficult and the was launched and the second OMC engine transferrede with the rocks. The other Avon at Minot Point the other four headed back. Hall dallliams to progress scientific work Whales off "Astrolabe Point". Out of sight ahead, Waghorn's reconstructed OMC engine boats and hauled them out. The sun had set long before. A tired and point, un loaded the the tentso 1 in 6 days Hall had, boated nearly 200 miles to get back where he started. It it was
still the 16 th.

The next four days were spent around basecamp tidying up stores, bullding a cairn
for the Belgica plaque, and trying to mconstruct outboard engines from four damaged This proved impossible with the basic tools carried; spares were requested from DNPTS by by early in her 3 rd Work Perlodo In the meantime the boating plans were abandonto to pass it was din her 3 rd Work Periodo In the meantime the boating plans were abandonned and
it tount Morgagni. bull Fur Seal on just before departing Waghorn was badly bitten on his left thigh by a Minot. Point, and fetched the doctor. Williams inserted 16 stitches, photographed by a
rather green Hall. Williams stayed with Waghorn on 22nd, while Clements, Gill and Hall departed on
skis with pulks to lay a cache ready to attack Mount Morganl with much cloud, taking four days with heavy pulks in unfamili lar terrain to put a cache weother near "Cushing coll"s On 26 th they started back in poor conditions. Hall fell $35 \mathrm{ft}$ into a

On 27 th Hall and Clements took Williams back to Minot point by boat. Waghorn
skied to Skua Bluff, (unroped) and decreed his filtess satisfactory. The Rearlink "Astrolabe Point" next day, outboard motor spares. The four of them prepared to leave for

Minot Point Scientific Party. 12 February - 9 March 85. Moffat, Hughes \& Williams.

As described above, they landed at Minot point on 12 th. Until 16 th much of theit Hughes was with the boats most of the thime capsized boats and repair broken engines, and Party ware in communication with the southern. Party, and also with Metchnikoff Moint when when
occuplede.

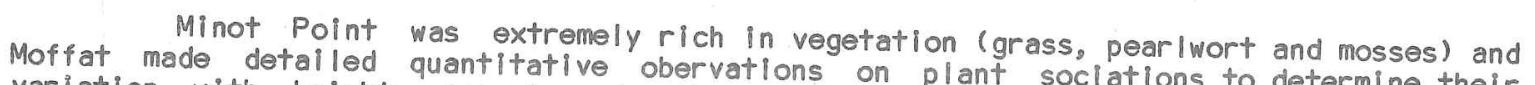
variation with height, aspect and orther factors. One maln reason for this luxuria their in a 3-week per lod when high winds were recorded elsewhere on the island. There 5 knots als ornithological interest for Hughes, particularly a large population of South Polar skuas

27th. The Willaams was fetched on 21 st to stitch up Waghorn, and returned to Minot on

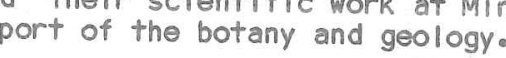

him on 9 March. 


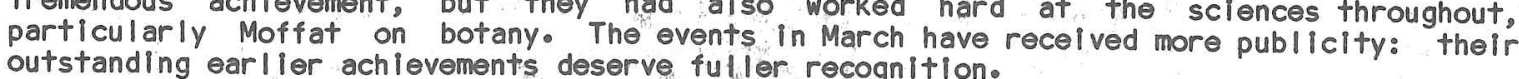

\section{Waahorn's Crevasse Fall and Injuryo 28 February - 9 March 1985.
Waghorn, Clements, Gill, Hall (and many others).}

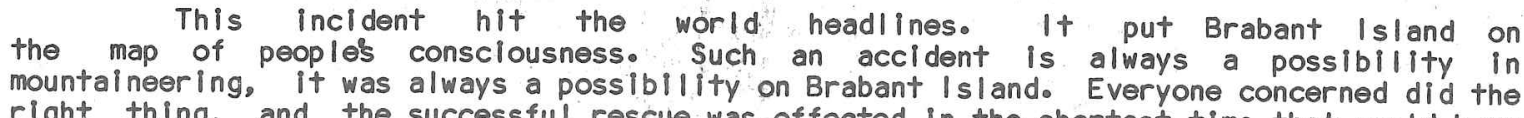

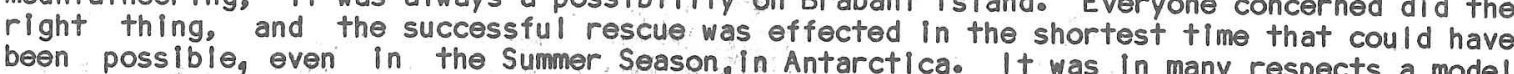
rescue. The chronological facts are set down here for the recordo

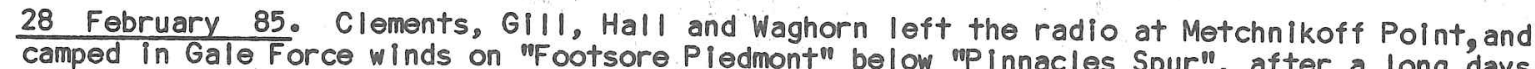
pulking.

1 March 85.0 In cloud they relayed the pulks over "Mobbly Col" and "Noddles col" and camped
on the head of Lister Glacler close under "Noddles Hat".

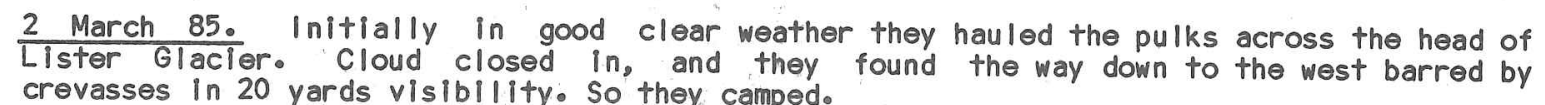

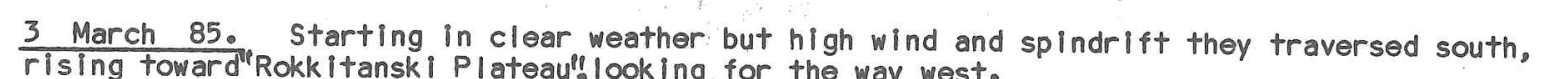

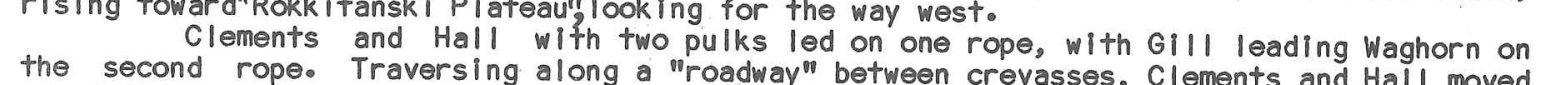
the second rope. Traversing along a "roadway" between crevasses, clements and Hall moved
up left across a fading crevasse lineo Gill foll lowed their trackso As he crossed the up left across a fading crevasse lineo. 6111 foll lowed their rackso As he crossed the
crevasse at about 1000 , waghorn moved $3 \mathrm{ft}$ left off the skl tracks. The roof of the

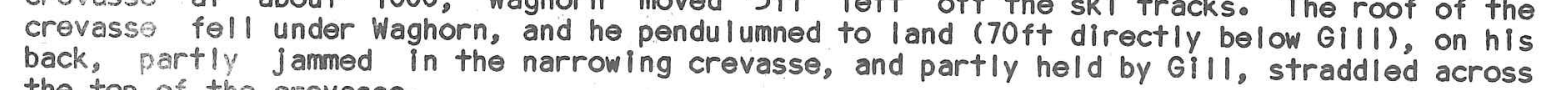
Blocks of snow and ice fell on Waghorn and one broke his right thigho
Blyents

GIII, then put in another with a jumar imon thately. They put in a deadman belay and secured GIII, then put in another with a jumar on the IIVe rope between GIII and Waghorno
Gill was shocked and bruilsedo. Telliling GIII to dig a tent platform, Clements put

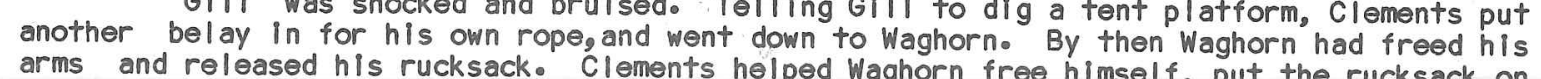
a wedged snow block, saw waghorn's right leg was bent "with two knees", and then Jumared out while clements lowered a First Ald pack and a flask of hot chocol ate to Waghorn, Hall
rigged a 2 to 1 pul lley system, wilth an Alpine Clutch.

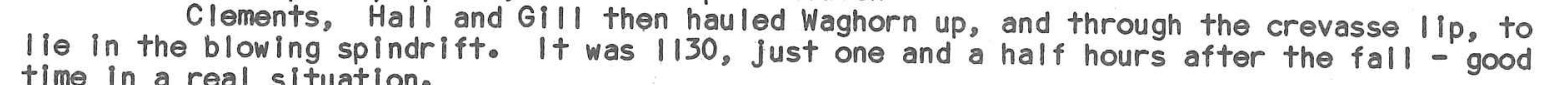

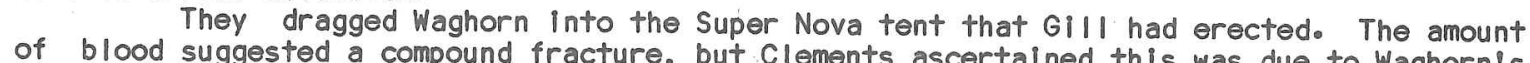
of blood suggested a compound fracture, but Clements ascertal ned this was doe to waghorn's
use of the omnipon paln n-killing syretteo. Clements stral ghtened the break, and left Gill to cut up a Will lans sit-Harness and spl Int Waghorn's legs together. Jumared outs with some difficulty due too icingo clements absel led down: Waghorn's rucksack had goneg, and the crevasse disappeared into blackness $200 \mathrm{ft}$ belowo. Clements Jumared out rope. The temperature was about - -10 c. Whith Waghorn's rucksack were lost his personal

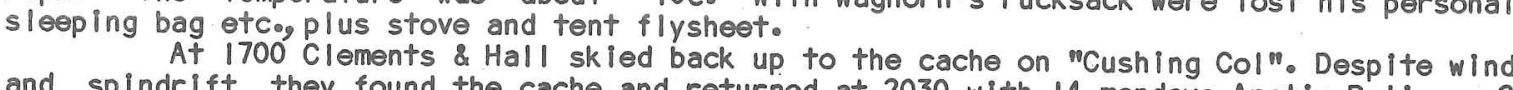

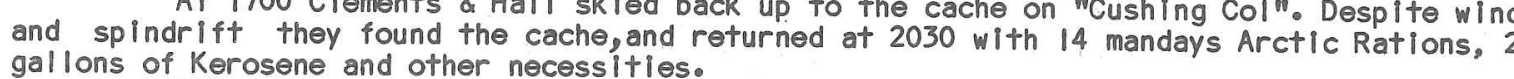

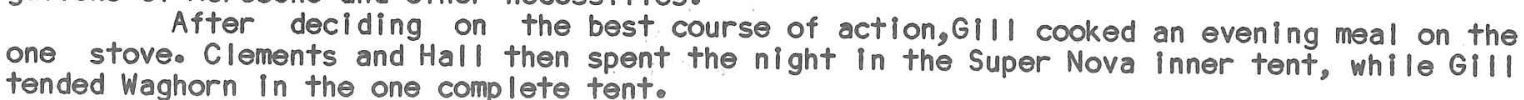
4 March 1985. At first 1 ight, before 0600 , Clements \& Hall sald goodbye to Waghorn and

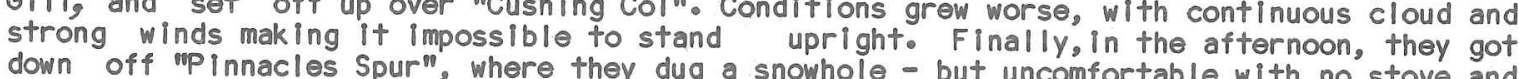
down off "ip Innacles Spur", where they dug a snowhole - but uncomfortable with no stove and only one sleeplng bag between theme Later in the afternoon the wind eased to Gale Force
and they forced on to reach Metchnikoff Poolnt at 1830 . They had, In one day of bad weather, comp leted a journey which normally took several days.

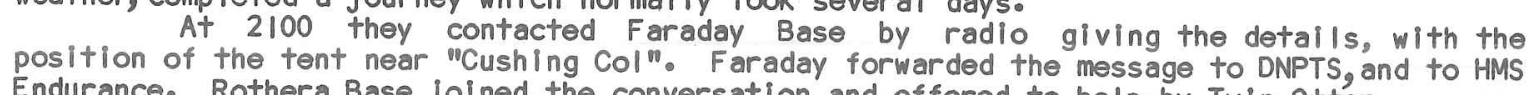

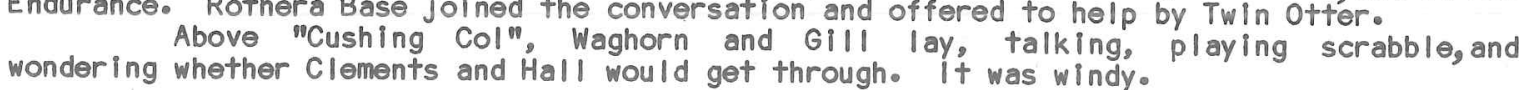

5 March 1985. Endurance received the signal in the small hours, in Port stanley: her did not have Chil theans at Rudol fo Marsh Base volunteered help, but their Bell hell copters Baseo SInce weather was bad on the Peninsula, these generous of fers were docl Inedg for the
tIme beingo.

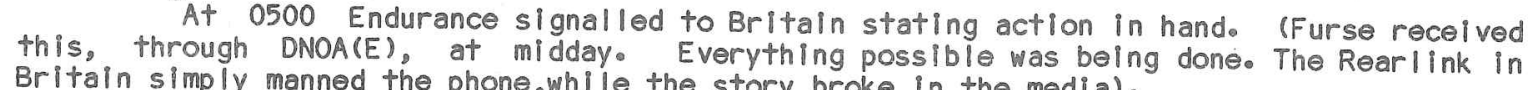

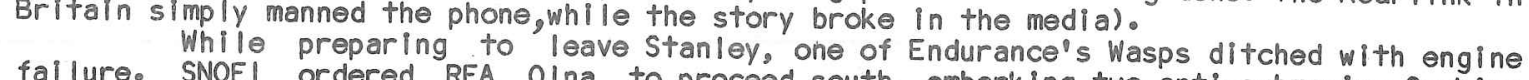

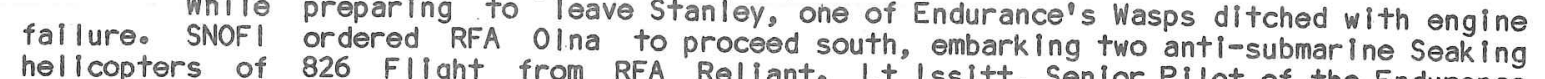

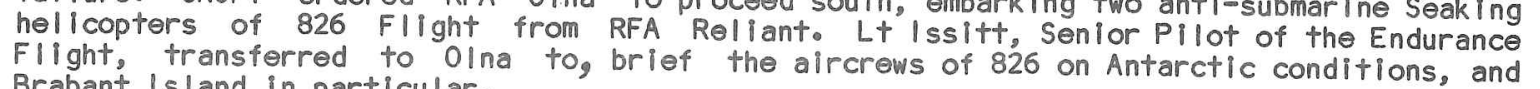
Mr Ed Murton flew up from Rothera Base in the BAS Twin otter that forenoon, in
appalling weather conditions. He overflew "Cushing Coll", but saw nothing through the cloudo At "Cushing Col" the gale of wind continued, Waghorn was reasonably comfortable
and the tent seemed secure. Waghorn and GIII heard the Twin Otter in the cloud and hope that Clements and Gill had got throughe clements and Hall had hoped to fetch the party froo Minot point to helps, but the weather and sea were too rougho They walted at Metchnikof
Point, talking by radio with Faraday and Minot point (and the Twin ottrer) Wednesday 6 Marcho RFA Olna was moving south across Drake Passage at nearly 20 knots,
ahead of HMS Endurance. Captain McLaren of HMS Endurance was In command of a 2 -ship Task

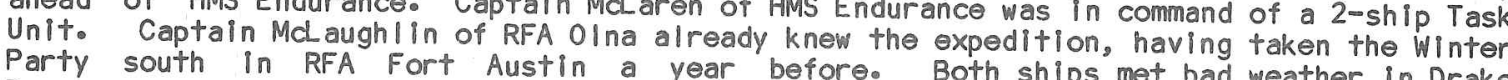
Ed Murton flew up from Rothera again in the BAS Twin otter. Agaln he met bad

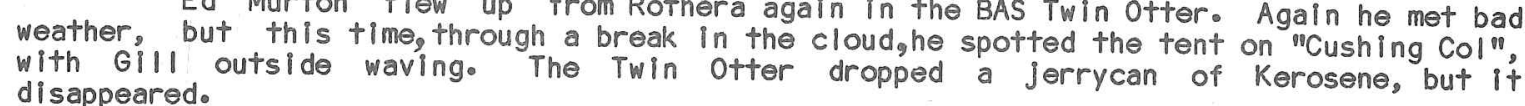
Waghorn was in surprisingly little pain, but conditions in the tent were
uncomfortablo. The wind had dropped, allowing Gill to go out, erect a good snowuall, and dig a snowhole in case the tent blew down. They sam the Twin otter and knew that help was on the way. The Jorrycan dropped within a ropes length, and Gill was able to

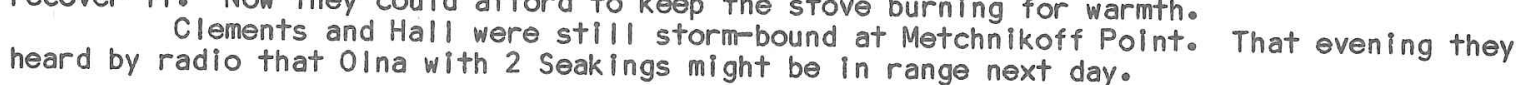

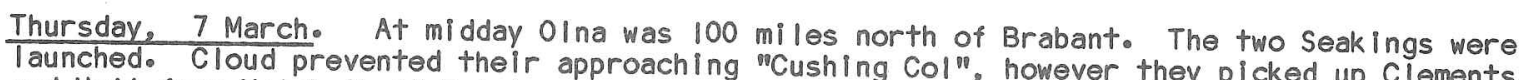

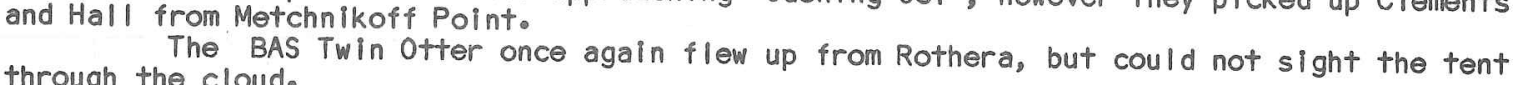

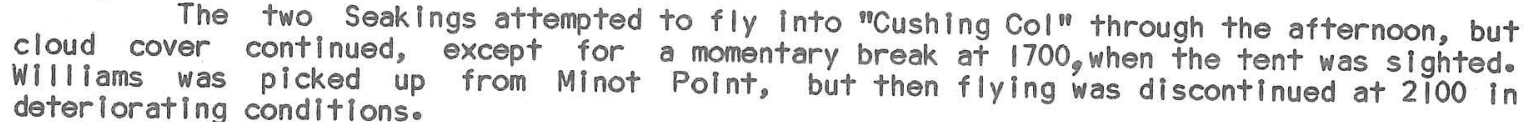

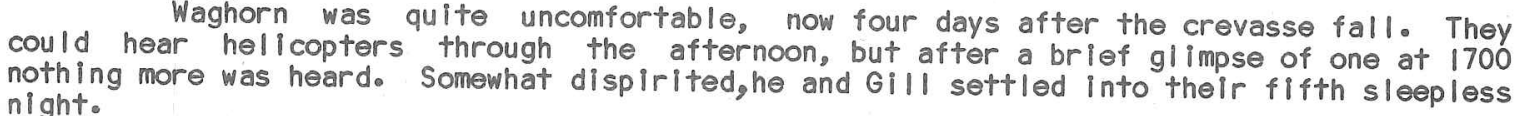
Endurance was still coming southo On board, Atkins and McLeod were busy making
deadmen and preparing to toke a team of Royal Mari nes ashore to go up to "Cushing Col" if
the helicopters were still held up by cloude.

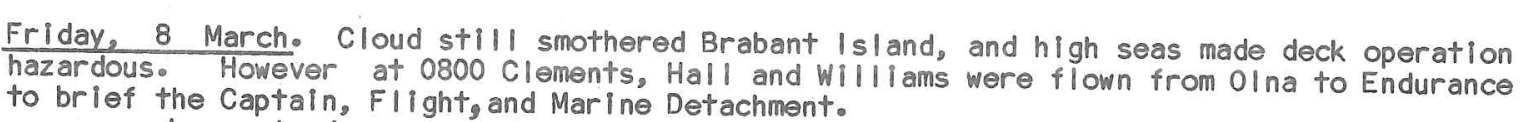
Low cloud prevented rescue, but one of the Seak Ings flew round the south end of
Brabant Island, plcked up Martin and RInge from "Dayglo Polnt", and then continued around Mclood, propared to to OIna. The Royal Marines in Endurance, with Atkins, Hall and Endurance, put when weather closed in they were landed on ol ina. 5 -man groups were 1 iffed off

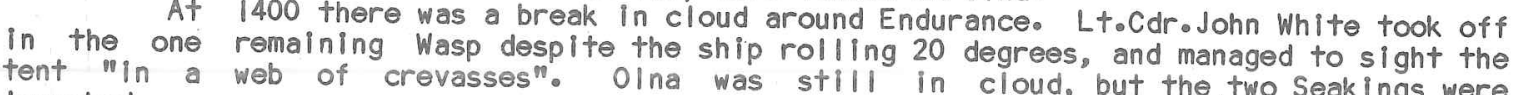
launchede One Seaking winched will lams down to the tent, plus Claments and 3 Marlo

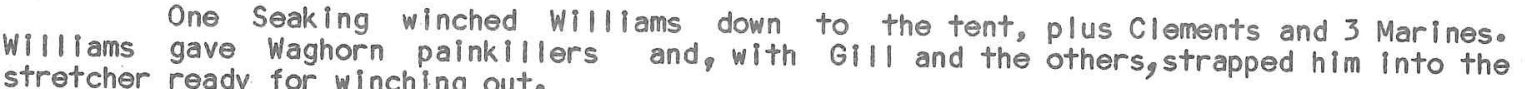
At $3 p m$ the Seak Ing lifted Waghorn out and flew him back to 01 na. As the cloud
closed in again the others were winched out alsou

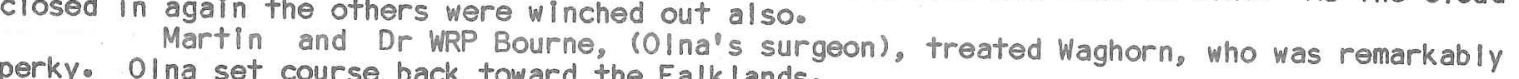
Back In England, the Plcture Eld tor of the Mall on Sunday finlshed printing
Corbett's plctures and returned to Londono The successful rescue, in only 5 days, had 


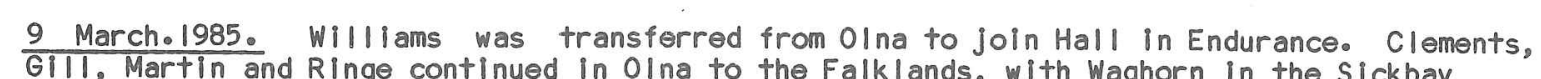

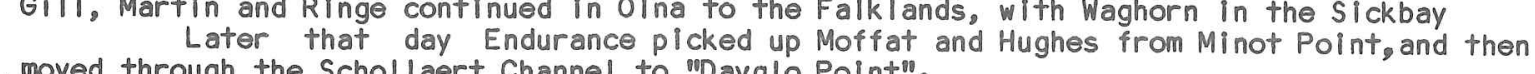

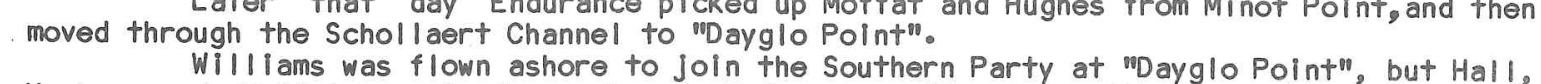

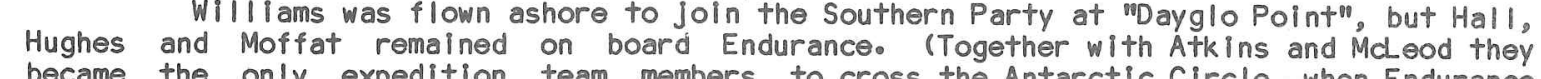

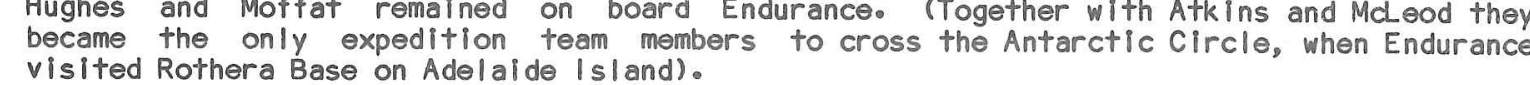

10 Marcho. OIna approached the Falkl ands and the two Seak Ings flew Waghorn and the others Is s ando waghorn, clements, GIII, Martin and Ringe were flown on to reach $S$ tanl ley that evening, but the other Seak Ing crew remal ned camped on Lively Is and for two days.
RFA OIna, HMS Endurance, and their hel I copters, had achioved an outstat

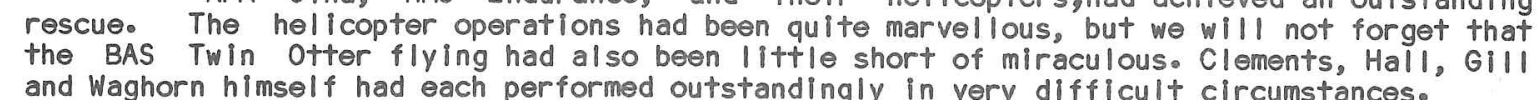

$$
-\infty 00--------
$$

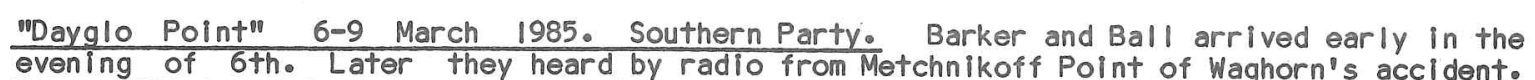
Ringe, Flint and Martin arrived at 2230 the same evening. During the rescue Ball was nominated by Furse as leader of the expedition in the
fleld, speciflcally for negotlations with Endurance on the further programmeg and final
recovery. Throughout 7 th they stood by at " wayglo Point" In case they were needed to help
rescue. On 8 th Martin and Ringe were IIfted out by Seak ing to help in the north, not to returno on the 9 th Tallor, Allen and Lawrence arr rved early in the evening. Endurance

\section{SECOND SUMMER NARRATIVE, FINAL PHASE.}

"Wayglo Polnt", 9-15 March 1985. Ball, Allen, Barker, Flint, Lawrence, Taylor \& Will lams. to continue local sciences, prepare stores for recovery, and spend two days on HMS Endurance 9-15 March 1985. Moffat, Hall, Hugheso

Whille there the three of them, together wilth Atkins and ind, south of the Antarctic Circle.

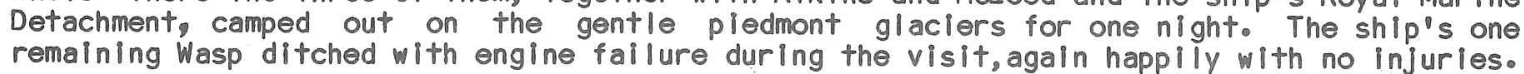
Recovery of Second Summer Partyo 15-16 March, 1985. Ball, Allen, Barker, Flint, Hall,

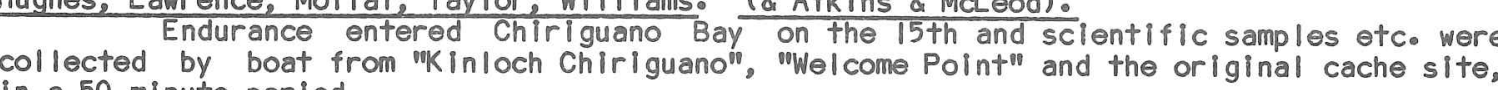
In a 50 minute parlod.

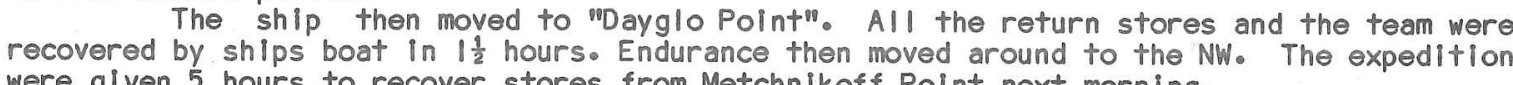
Starting at 0800 by going ashorechnikoff Point next morning. team members, plus Atkins and Mdeood, and several Royal Mar Ines from the Ships company with Ball and Atkins drlyIng In wet conditlons. trantically, bringing gear down 150 frt from basecamp, and loading the boatso. They did very
well indoed, getting all the Important stores, and only a small quantity of exposed fillm was subsequently found missingo Without hel icopters, recovery of the skidoos from "Astrolabe Point" was not
possible. It was hoped that these could be recovered during the ships 4 th Work Perlodo

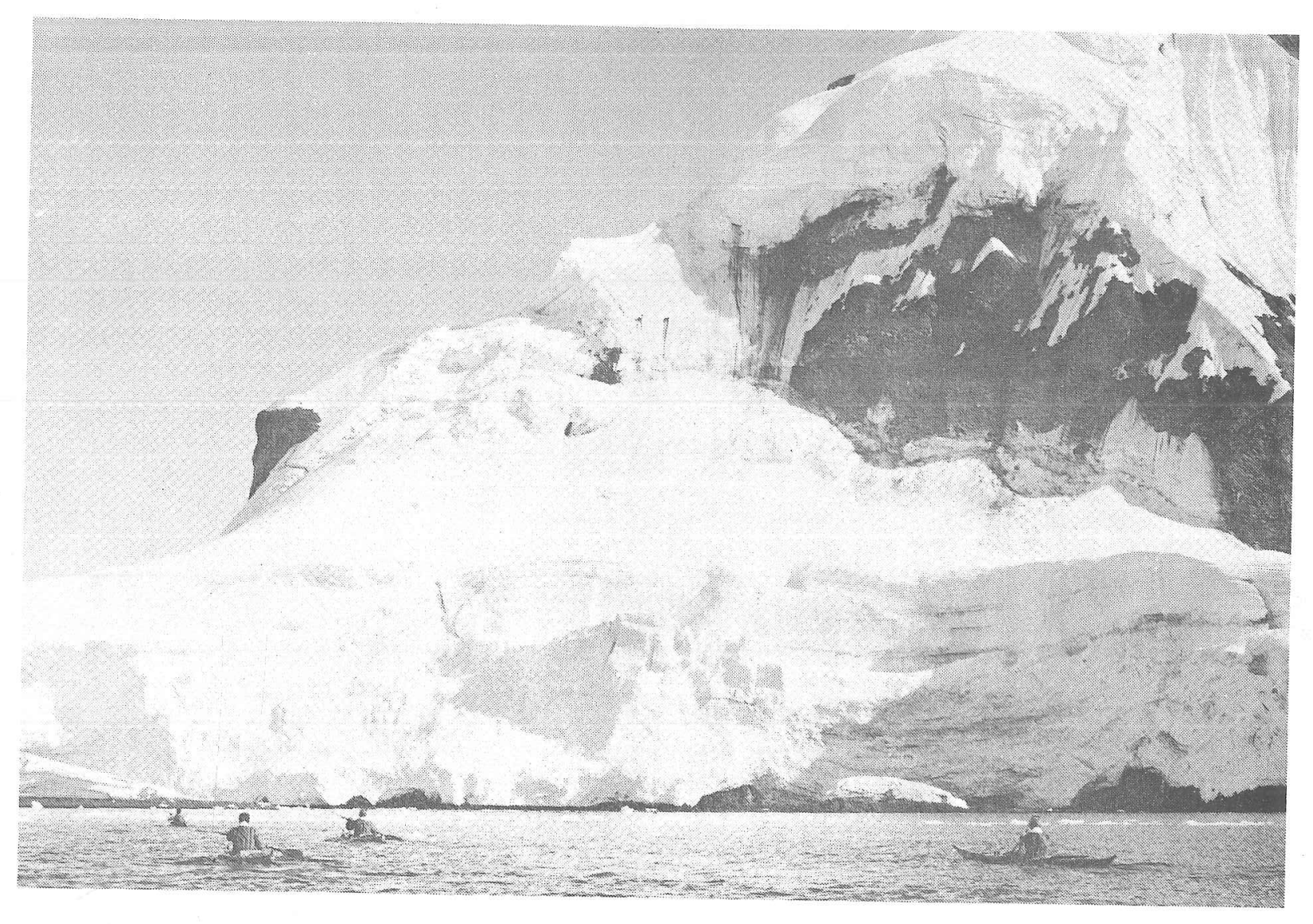

Circumnavigation. The four canoes head for a landing beach.

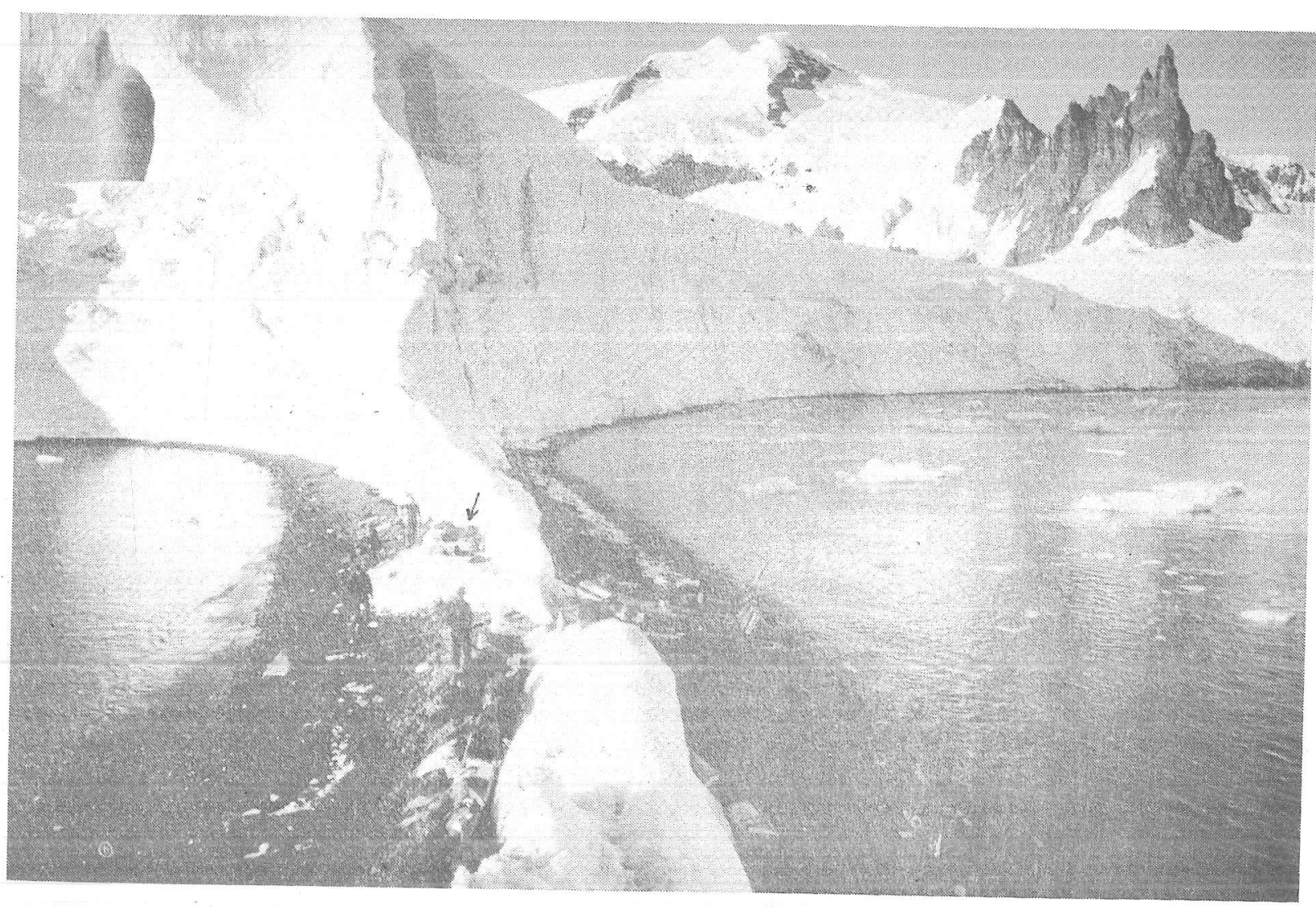

Circumnavigation. February 85 . Bivouac site (arrowed) just west of Mitchell Poin
This was the only beach found between 'Dayglo Point' and Cape Roux

E 


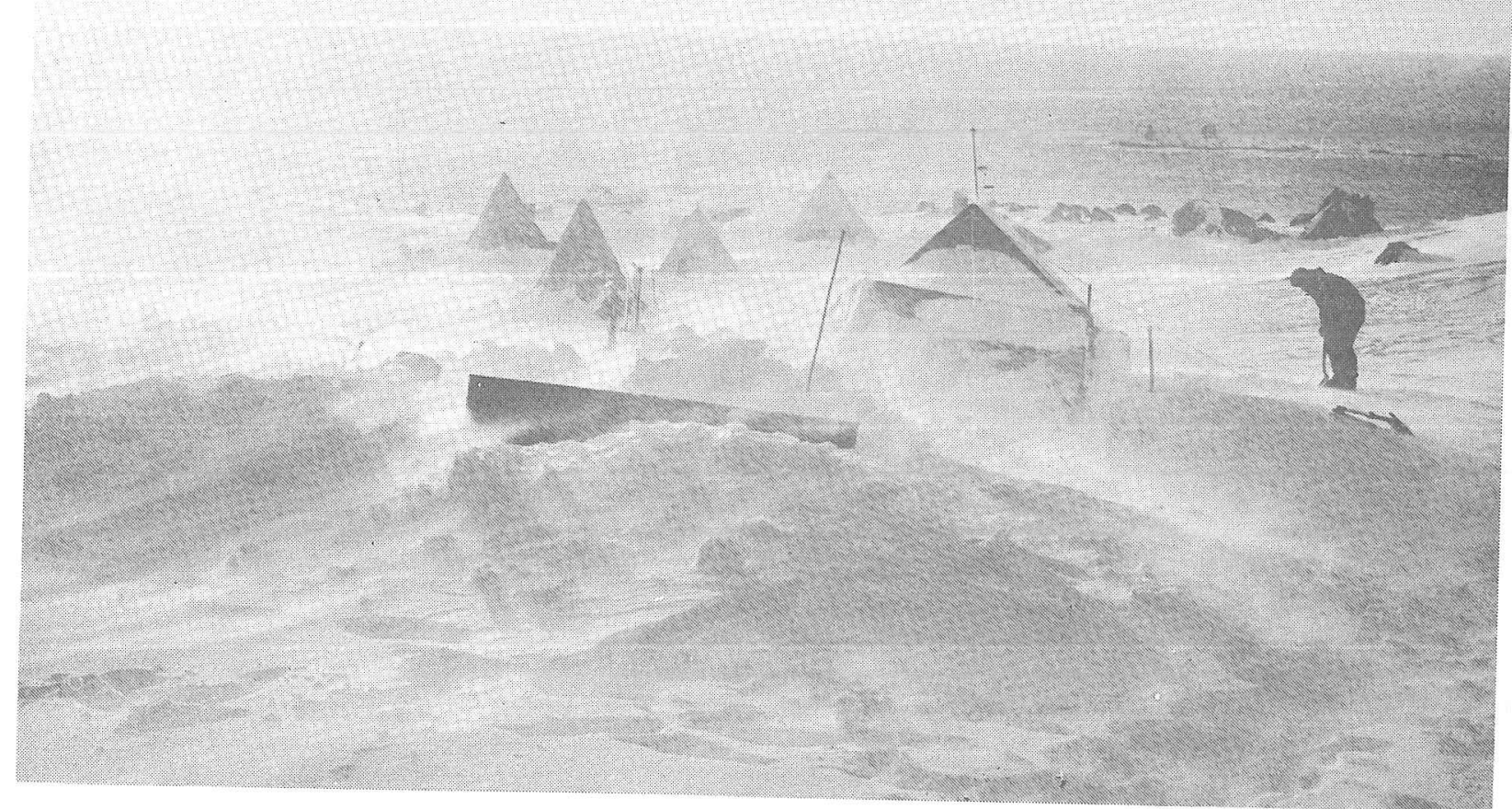

Basecamp in July 84. Winds keep the hut fairly clear, but the stores boxes are
repeatedly covered

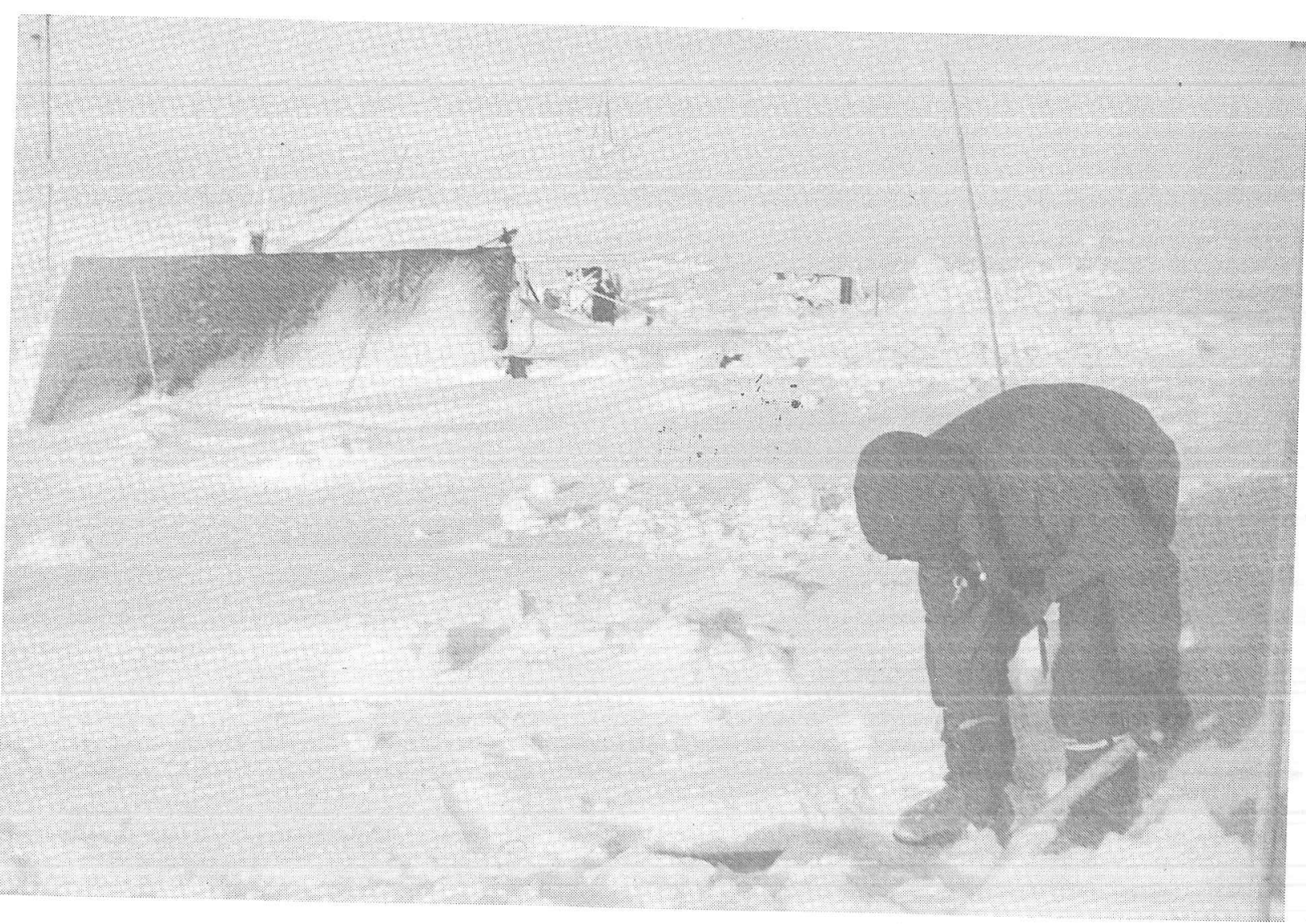

Basecamp in August 84. Digging down to the stores box. The hut porch has drifted
The return journeys were expected to be much simpler than the outward journeys, the tean they were rather more complicated. due mostly to the three evacuations.

FIRST SUMMER TEAM. $(7$ Men)

within sight of Brabant. Direct passage to Stanley. One day there.

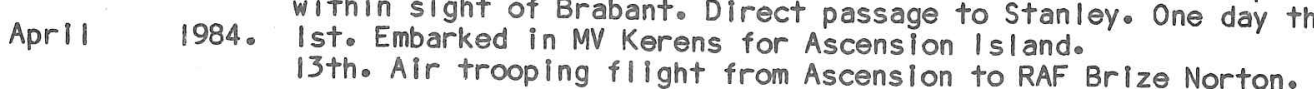

$\frac{\text { FIRST SUMMER RETURN STORES. }}{\text { March }}$

作

June 1984. Blological samples lost between Ascension and Britain

August 1984. Remaining stores returned in Endurance to Portsmouth. Blogical samples located in RAF Brize Norton.

WINTER TEAM: (Precautionary Medical Evacuation of Evans).

Punta Arenas after 8 John Biscoe from Metchnikoff Point. Landed at Punta Arenas after 8 day passage. C
Arenas to Heathrow, via Santiago.

WINTER TEAM: (Main 10-man group).
January 1985. 3 woek passage in Endurance after re-embarkation, Including survey
of Orleans strait \& visits to Palmer, Faraday, Bernardo O'Higgins an of Orleans strait \& visits to Palmer, Faraday, Bernardo O'Higgins and
Signy Island bases. Signy Island bases.
22 nd -2 days in Stanley. 25 th - Trooping flights for 9 men from Stanley via Ascension Island
to RAF Brize Norton. (Atkins Jolned HMS Endurance crew, returning to
Portsmouth June 1985). WINTER TEAM RETURN STORES.

(isembarked in Stanley

April 1985. Container finally cleared customs in Britain \& delivered to PSTO(N)
Portsmouth.

$\frac{\text { SECOND SUMMER TEAM: (Casualty Evacuation of Greenway). }}{\text { February 1985. Ist - Embarked in MY Polar Duke from "Dayglo Point". }}$

4th - Landed at Punta Arenas after 5 day passage. X-Ray in Punta Arenas showed fractured tibla, leg put in plaster.
5 th - Commerclal air filights from Punta Arenas to Heathrow vila Santiago,
Montevidoo \& Amsterdam, accompanied by RAF

$\frac{\text { SECOND SUMMER TEAM: (Casualty Evacuation of Waghorn, plus four). }}{\text { March 1985, 99th - Clements, GIII Martin }}$ RFA OIna direct passagartin \& Ringe with Waghorn, embarked in 12 th - Landed Stanley by Sea King hel icopters of 826 Flight
17 th - Trooping flights via Ascension to RAF Brize Nortono

$\frac{\text { SECOND SUMMER TEAM. (Main group of } 10 \text { remaining). }}{\text { March }}$

ath - Williams landed by Endurance at "Dayglo Point"。 Moffat, Hall \&. Hughes remeined on board Endurance Dayglo Adelaide Island. rescue, crossing the Antarctic circle en route to 14th - Remaining seven (Taylor, Allen, Ball, Barker, Flint,

April 1985. 59 th - - Alir Trooping flight to Ascension. Two days at Ascension I sland due vclo engine defect.

SECOND SUMMER MAIN RETURN STORES.

samples returned with teamo Remaining stores disembarked in Stanley and
stan samples returned with teamo Remain ing stores disembarked in Stan
transferred to container for return by ship.
container cleared customs and delivered to PSTO(N) Portsmouth.

May

SKIDO0S. The three skidoos had been cached at $1000 \mathrm{ft}$ above "Astrolabe Point" in December 1984. They could not be recovered in March 1985 due to the lack of hellcopters.

ATKINS returned as a member of HMS Endurance's Ships Company, arriving in Portsmouth
On 4 June 1985. 
A The first parts of the is land have still never ben visitede Most of our high
smalo
priority objectives were achieved, and also many of the lower priority ones.

GEOGRAPHICAL SCIENCES

Geology. Field survey covered most of the island, plus a few offlying islets. The subsequent analysis is expected to have regional significance.

作

idal data. Fragmentary records in NW showed much greater range than the predictions.

(a)

. cycle events \& activities recorded. Autumn \& winter records provided some new data on semi-pelagic foraging populations, and unexpected mi gration records. lations, including Fisho About 80 specimens (of 3 specles) caught: morphometric data \& samples col lected Parasites. Small collections made from 6 host species habitats should enable determination of the Arthropods, Nematodes, Rotifers, Tardigrades and Testate amoebae present, fllling a gap in present knowledge Field data collected o

Microfunglo Col lections made from var ious areas and habitatso
Botany. Collections around Brabant Is and will fill a gap in the known distribution of

specieso Quantitative field data obtained at two points (with unusually rich stands of
Grass \& Pearlwort both setting seed) provide the basis for an ecological analysiss.
Museum material. Miscellaneous zoological material collected for Royal Scottish Museum.

\section{HUMAN SCIENCES}

Physology. About 60 mandays of 24 hour multichannel temperature data recorded。 Many days fluid balance recording \& blood samples have already. provided the first scientific analysis will signiflcantly increase knowledge on cold survival. Group Social Structure. Regular questionnaires completed over the winter for analysis.
Individual attitudes. Statistical records of pleasures, mi series, cravings \& dreads.

MOUNTAINEERING.

First Ascents. Mount Parry (c8400 f+) and 54 other major \& minor peaks.
Sledaing. One-man pulk sledging technigues refined for totally self-supporting parties mountaineering for perlods of up to 5 weeks.

$\frac{\text { BOATING. }}{\text { Inflatable power boats. The } 140 \mathrm{mlle} \text { First Summer journey from Palmer Base to Metchnikoff }}$ travelled a total of nearly 1100 boat-miles. Canoess All but 14 miles of the 100 mile circumnavigation of Brabant Island were padd

CAMPING.
The first demonstration that teams can live, move \& work safely (and in
reasonable comfort) in tents for a complete winter (and complete year) in Antarctica.

$\frac{\text { FUTURE EXPEDITIONS. }}{\text { Public SuMport. }}$ The success of this expedition should help gain support for other expeditions to the Maritime Antarctico. Leaderso. The 35 team members have all gained experience in organ isation as well
the fieid, to equip them as Leaders or Assistant Leaders of future expeditions.

Planned Expeditions. Three team members are already planning future expeditions:

a. Flight Lleutenant BIII Hankinson RAF: AxeI Heiberg Is I lando (Multi-disciplinary JSE).

$\begin{array}{ll}\text { b. Corporal John Spottiswood RE: } & \text { Brabant Islando (Mountaineering, Unit team). } \\ \text { bouth Georglao (General adventure, Unit team). }\end{array}$

$\frac{\text { PUBLIC RELATIONS. }}{\text { Good recruiting material provided for the Services, plus good general PR material for the }}$ PERSONAL.

It is hard to measure the effects of the expedition on the 35 team members 8 RN, 5 RM,

14 Army, 5 RAF and 3 Civillanil 33 of them had never before visited Antarctica.

zest for life \& adventure to widening circles of friends and aquaintances.

I think we did well, and I am sure the results will prove useful.

Most of the island has now been covered. However the following few areas were not
visitede

a. Mount Morgagni \& Spallanzani Pointo Interesting geology,

b. Hulot Peninsula \& Mount Bulckeos interesting, but limited geology and ornithology. Challenging first ascents. Landing

c. Humann Point \& Mount Erlicho Interesting geology, ornithology,

botany geomorphology and terrestrial invertebrates.

d. Buls Bay \& Avicenna Bay. Interessing geology, and possibly
ornithology and botany etco Climbing aboves Several reasonable

e. Fleming Pointos. Interesting geology, geomorphology,

f. Mount Parry Northwest Ridge. Superb $8400 \mathrm{ft}$ snow and ice

from Minot Pointo (Spottiswood is planning a 4-man expedition),
g. Mitchell Pointo Interesting goology and ornithology Difficuit
beach access.

Some other follow up scientific work may be shown to be desirable as post-expedition analysis progresses. If so, the following are the most promising areas (possibly the

h. Metchnikoff Pointe Ornithology, Terrestrial invertebrates.

1. Claude Pointo Ornithology, Botany, Geology. Usable beach,

1. Claude climb out very difficuit/Severe.
j. "Astrolabe Point". Botany, Invertebrates. Difficult landing.

k. Minot Pointo Botany, Terrestrial Invertebrates, Geology,

1. Chiriguano Bayo Goology \& Mountaineering. Superb beaches.

The following useful small caches remain on the island. Quantities are very rough ifgurese Further detalls are avallable from Furse.

"Dayglo Point": Hut: 1003 mandays rations 303 Gals Kero 903 Gals Petrol + General Metchn (The hut \& garage are unlikely to survive more than one winter).

Claude Point:
"Astrolabe Point": 203 mandays rations 203 mations 5 ? Gals Kero (3 skidoos at $1000 \mathrm{ft}$ above are not expected to survive the winter).
$30 ?$ Gals Petrol
Driencourt Point: Minot Polint:

$50 ?$ mandays rations $3 ?$ Gals Kero
1003 mandays rations 10 Gals Kero $\begin{array}{ll}\text { Fleming Point: } & 1003 \text { mandays rations } 60 \text { Gals Kero } \\ \text { Humann Point: } & 1503 \text { mandays ratlons }\end{array}$ 45 Gals Petrol

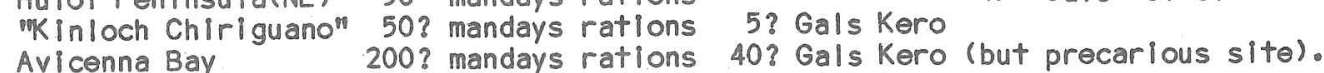




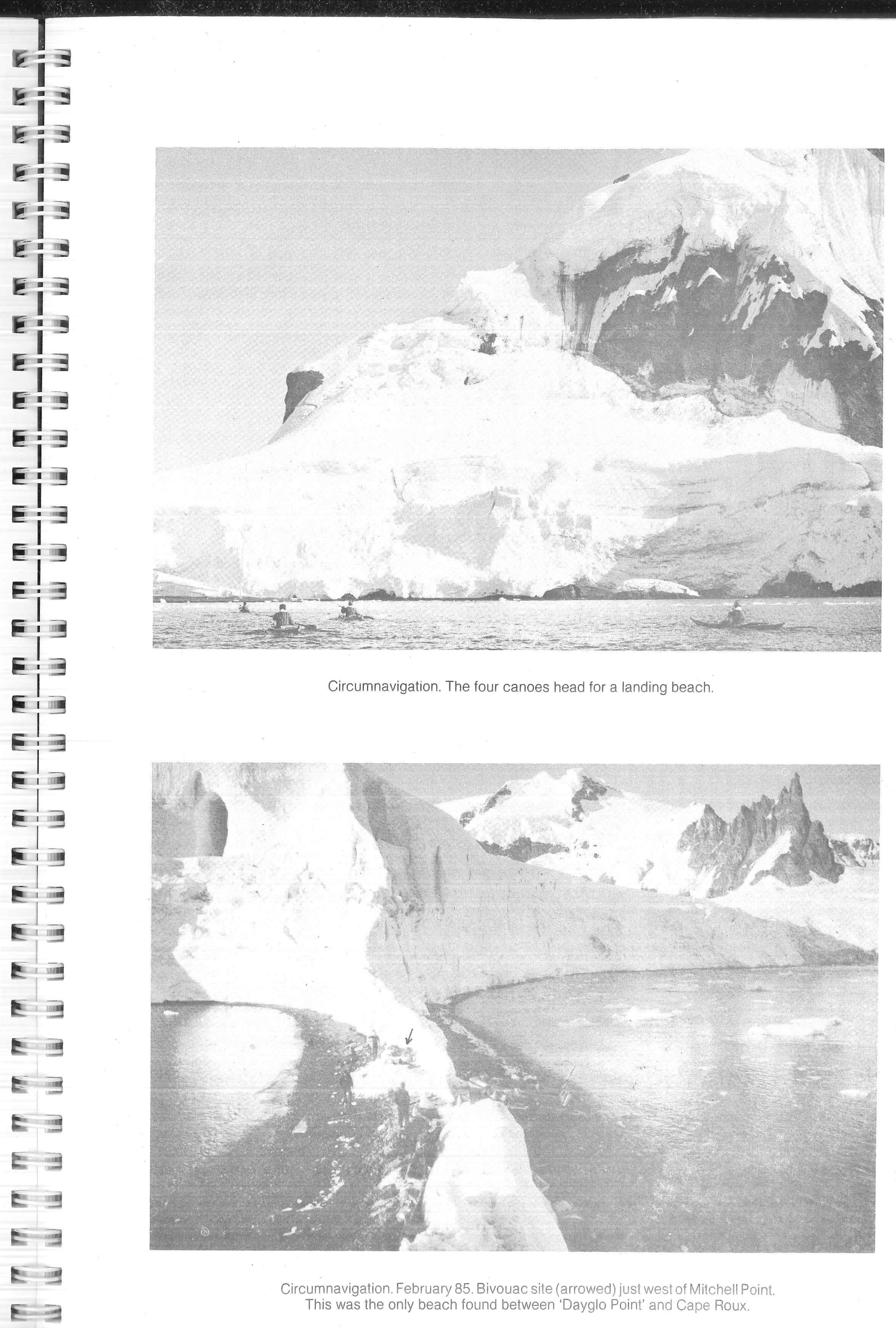




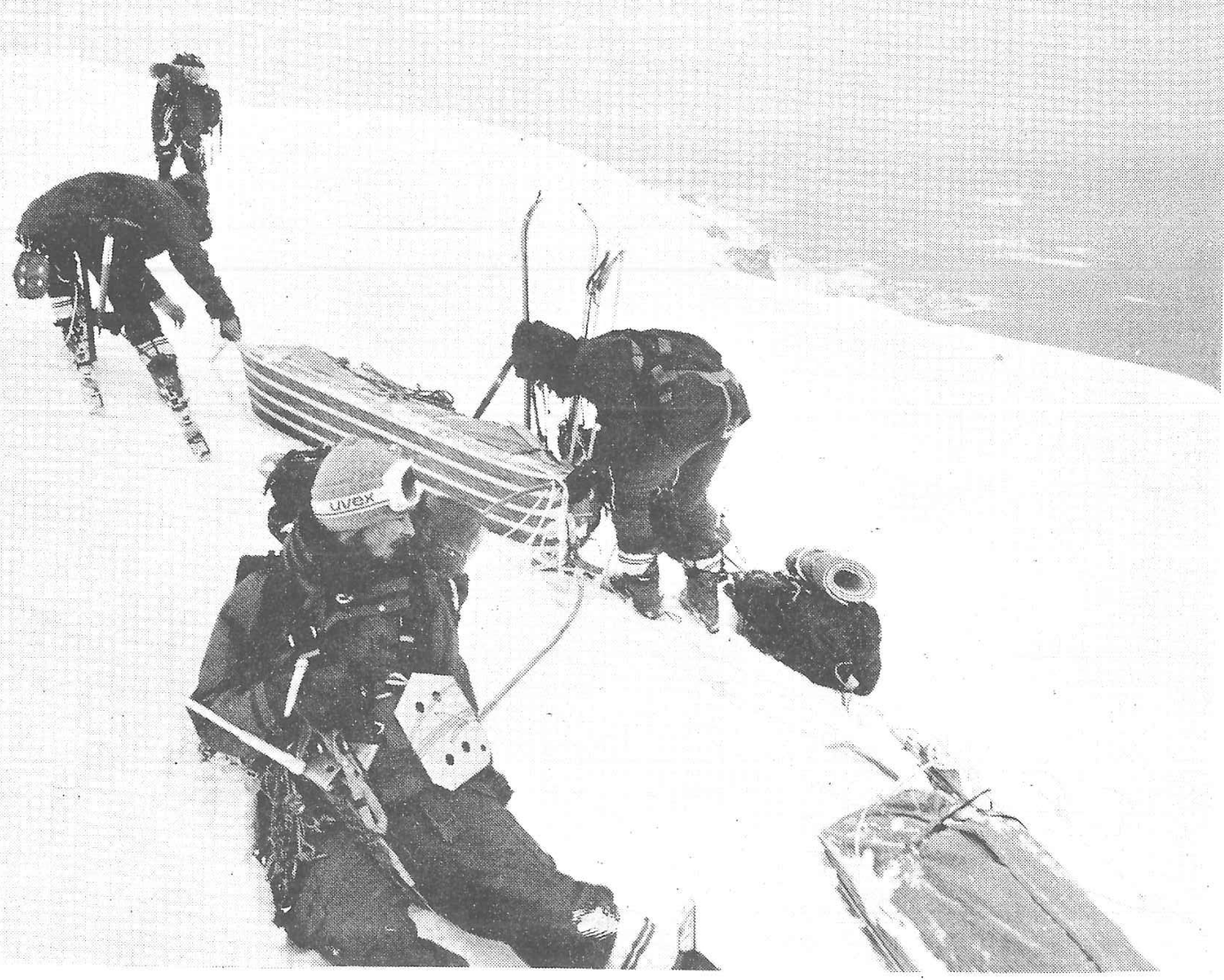

scientific flelds. Flint, Mart in and Moffat had each undertaken win their own professional years of a Trathen had an approprlate honours degree, and Stuttard had completed two education, Furse was an experienced amateur in his fleld, and Morris, Hankinson andandar each had some related fleld experience; however Clements, Evans and Williams were allocated being allocated scientific tasks, Ate and Hughes were keen amateur naturalists. After

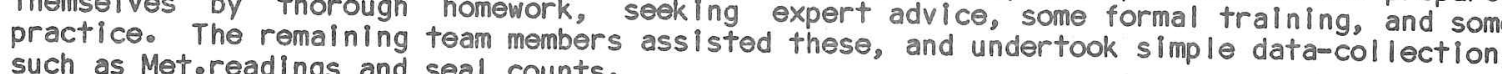
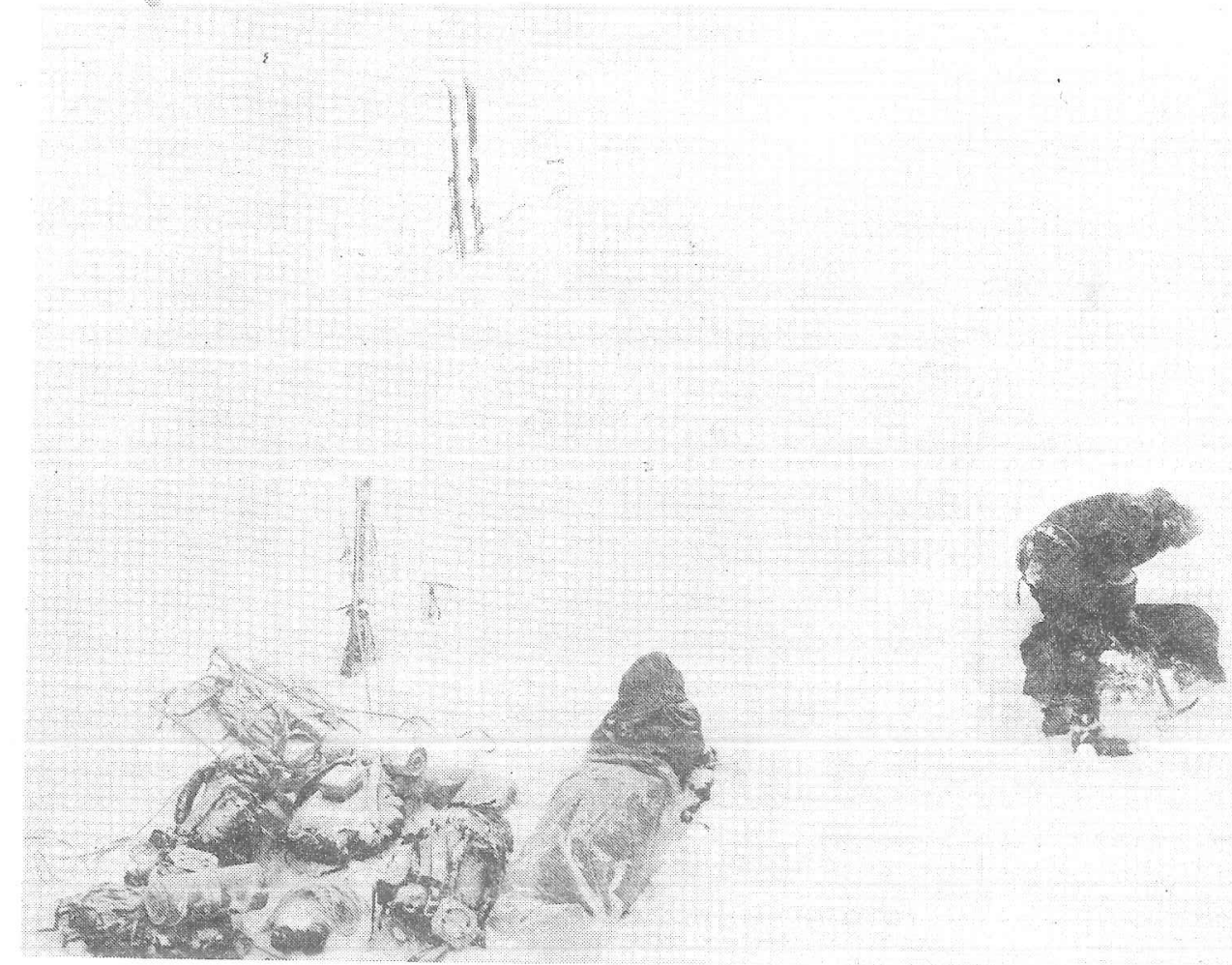

After Evans' crevasse fall April 84. Beattie and Spottiswood dig snowhole on right,

Widely varying sclentific projects were undertaken, within the competence of team
ranging from the complete geological survey to collection of a few ssaveed samples members (ranging from the complete geological survey to collection of a few seaweed samples themselves, but the majority resulted from direct approaches to individual researchers Identifled from the Directory of University Research; and some projects were undertaken in collaboration with the British Antarctic survey, A potentlal over load of scientific work (particulariy in winter when travel was limited), and to cover against lack of supjec 26 mater on the island, or equipment fallures etc. Altogether 81 projects were arrangect 26 by expedition team members, 15 in collaboration with BAS, and 40 for other outside
researchers.

coverage of the priority of the expedition as a whole was the widest possible scientific Individual projects were al located Priorities, from $A$ dous $=$ max. Within this framework, importance of the data, on the interest shown by the specialists recelving the percelved and on our expectations for achieving worthwhile fieldwork. In the list below, these

physical In general we achieved most of our targets. Some shortfalls were due to the were due to lack of subject material. A very few shortfalls in the fleld resulted from produce some follow-up projects in the second summer, but temporary loss in trannit of mould Second First Summer samples for several months frustrated this. The early finish of the Second Summer phase after Waghorn's injury also curtalled some projects. Notwithstanding
these miscellaneous problems, the samples and written data we have obtained should provide
good raw material for subsequent analysis to put Brabant I sland on the sclentific map(s).

In many cases documented collections and raw field data are simply being passed
to the relevant specialists for their analysis. However the results of some projects be worked up by the team members concerned, producing collated data and in several cases findings: other data wlil scientific papers are expected to arise directly from our geographic and taxonomic review papers. In the list below, the name of the person undertaking post-expedition analysis is shown in brackets.

analysis. We have very generously given the expedition a PCXT computer for post expedition coordinat met.records) sample detalls, publications etc. This will provide unrivalled the data simply and quickly. Oakley is the BID Manager. who will be able to access all

fleldwork the brief reports in the following appendices indicate the nature of the fleldwork and coverage achieved, but few attempt to describe the results. My book about
the expedition (and the island) will include more of the prel iminary findings, although in
many cases the full analysis of our material will take several years.

interest I in the post expedition analysiso coples of af all to take a keen and active be collected, together with summaries of unpublished results, outlines of any ongoing work sets of these Geographical Society and the Scott Polar Research Institute to provies of the Royal compedition in particular (by that time the two Brabant Island in general, and from this 
(Appendix 1A。 Page 2).

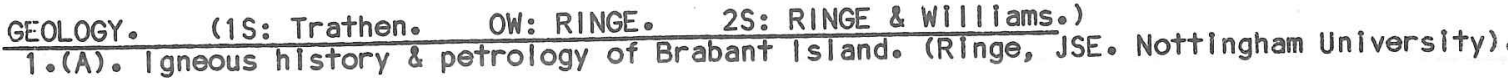

GEOMORPHOLOGY. (1S: Trathen. OW: Evans. 2S: FLINT.)

2. (D). Large-scale mapping of patterned ground. (No sultable sites found)

3. (C). Beach formation processes. (F I int, JSE, with Dr.Hansom).

5.(C). Intertidal rock platforms. (Flint, JSE, with Dr.Hansom).

6. (B). Intertidal boulder
$7 .($ ). (Project deleted).

9. (B). Sub-tidal slope proflles by echo-sounder (equipment defective)
10. (C). Glacler fluctuations. (Flint, JSE. Notes for reference, little evidence avallable).

GLACIOLOGY. (1S: no-one. OW: Evans. 25: TAYLOR.)

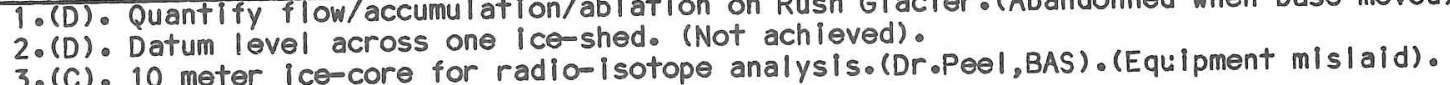

SEALS \& WHALES. (1S: Worrall. OW: Spottiswood \& de Gerlache. 2S: Clements. 2.(A). Crabeater Seal winter feoding samples. (Dr.Croxall, BAS). (Not enough seals)

3. (C). Crabeater Seal skeletons a skulns (Nor) found in 3 seals examined).

5.(B). Microfungl on moulted seal skino. (Professor Pugh, Portsmouth Polytechnic).

6.(D). Blubber samples for organochlorine analysis. (Dr.Skelton). Not achieved,
7.(D). Whales, records of all sightings. (Furse, JSE, collated data for BAS reference).
B. (D). Ectoparasites from sealso (British Museum of Natural History reference collection).

MARINE BIOLOGY. (1S: HIII. OW: Kimbrey. 2S: Clements.)

2.(C). Fish for display (Royal Scottish Museum)

3.(C). Fish muscle physlology samples. (Mr .Nell Fitch), StoAnd

5.(D). Marin invertebrates for display. (Royal scottish Museum).

6. (D). Mussels: annual cycle data. (Dr.Davenport.

ORNITHOLOGY. (1S:FURSE. OW:FURSE, Oakley \& Evans. 2S: Hughes, Greenway \& LewIS.

$1 \cdot$ (B). Breeding censuse (Furse, JSE.)

2. (B). Penguin foraging routines. (Abandonned - no suitable study colonies found).

(C). Seawatches to record coasting movemonts. (Furse, Jse, stul

Soyal Scottish Museum?

(Notion).(Not achieved).

(Drowill lams, Hull University). (Not achleved).

(D). Penguín tapeworms. (Drokar in Andersen, Os lo University).

9olytechnic).

(D)

(C). Kelp Gull foraging data. (Dr.John Croxall, BAS,

(D). (Droxall, BAS).

15. (D). Breeding adaptations data. (Irene Werth, Leeds University).(Project vague).

15. (D). Breeding adaptations data. (Irene Werth, Leeds University). (Project valo
16.(C). Multivariate analysis breeding dates in region. (Furse \& Oakley, JSE).
(Appendix 1A. Page 3)。

BOTANY. (1S: Hankinson. OW: Stuttardo 2S: MOFFAT \& Martin). (Professor cram ford).

3.(C). Moss-turf \& moss-carpet reference sites descriptions. (No suitable sito

4.(D). Mossbanks, descriptions. (Dr.R. . LL.Smith, BAS). (No mossbanks found)

6.(C). Mecrofungl \& moulds (Dr.Ray Watllng, Royal Botanic Gardens, Edinburgh).

7.(C). Microfungl from various habitats. (Prof.Geoffrey Pugh, Portsmouth Polytechnic).

8.(C). Predaclous microfungl. (Dr.Wyborn, Central London polytechnic).

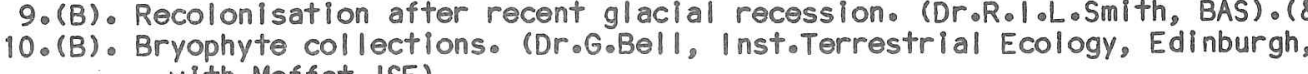

11.(B). Vegetation analysis after receding ice-cover. (Moffat JSE, with Dr.0xley). (\& see 9).

TERRESTRIAL INVERTEBRATES. (1S: Morriso OW: Beattie. 25: MARTIN \& Hughes.)

2.(D). Mites \& springtails annual population dynamics. (Dr.BIII Block, BAS).

3. (D). Belgica antarctica population dynamics \& distribution.(Dr.Blli'Block, BAS)。

4. (C). Gut contents of commoner arthropods. (Dr.Blit Block. BAS).

7. (C). Tardi grades col lections. (Miss Sandra Macl nnes, BAS).

8. (C). Protozoas testate amoebae collections. (Drotumphrey Smith, Coventry Polytechnic).
9.(C). Morphological variabillity of Belgica antarctica. (DroMke Usher, York University).

10.(D). Arthropod collections from Falklands in transito (DroMike Usher, York University).

11.(B). Life cycle data on the tick 1xodes urlae. (DroBill Block, BAS).

PHYSIOLOGY。 (OW: OAKLEY)

1. A). Accilmation to central cold stimulus. (Oakley, JSE, I nstoNavoMed, wIth Dr.R.Goldsmith). 2.(A). Comfort of clothing \& tents. (Oakley, JSE, and Institute of Naval Medicine),
3.(D). Surface temperatures of seals \& penguins, Incidental measurements. (Oakley, JSE).

PSYCHOLOGY \& SOCIOLOGY. (15: Hankinson \& Morr Is. OW: Stuttard \& Furse. 2S: Bal1).

2.(D). Changes in circadian rhythms. (Drofolkard, Sussex university).

3. (D). Analysis of pleasures/miser ies/cravings/dreads questionnaires. (Furse, JSE).

4.(D): Control of circadian rhythms by melatonin.(Dr.A.
5.(D). Stress-related health problems. (Morris. JSE).

6.(C). Social interactions within isolated group. (Morris, JSE, with Barts.Hospital).
7.(D). Use of data-logger for reaction tests in cold climates. (Not achleved, technical

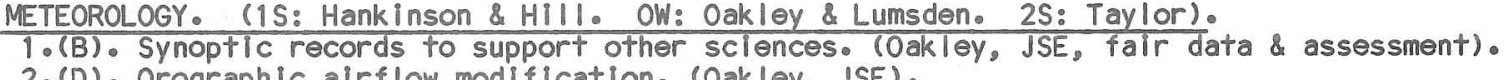

SURVEY. (1S: ATKINS. OW: ATKINS \& EVans. 2S: Hughes \& Allen).

2. (D). Helght checks of DOS map by altimetry. (Atkins, JSE, falr data to Dos:, JSE).

3.(B). Map Cairn Point by photogrammetry. (Not achieved due ship programme changes).

$\frac{\text { HYDROGRAPHY and OCEANOGRAPHY. (1S: MCLeodo OW: Evans. 2S: Waghorn \& Tay lor). }}{1 .(B) .1 \text { ceberg drifts \& surface currents. (Abandonned due equipment problems). }}$

2.(C). Sea-ice cover through the year. (Evans, JSE, fair records for reference)
3.(C). TIdal records in Bellingshausen Sea. (Supt. Tildes, Hydrographer) (Incomplete data).
4.(C). Amendments to the Antarctic PIloto (Furse \& Waghorn JSE for Hydrographer). 
The aim, to sample \& map the geological formations of Brabant Island, was to a
great extent fulfillied, with over 350 samples being collected. Subsequent analysis at the University of Nothingham should enable a detailed geological history of the island to be
deduced. Although a brief geological reconnailsance had been carried out by the ChIleans in
1977 , our own more detalled \& extensive study will greatly enhance existing knowledge. The mapping of Brabant I sland does allow the basic outline of the geological
history, given below, to be pleced together, and more detalled informatlon from the 300 t
samples still awalting analysis will eventually further enhance this. However 40 samples
collected by Trathen have already been analysed and show interesting results. From these collected by Trathen have already been analysed and show interesting results. From these it would appear the island's geological setting is probably a spreading back-arc basin. With Basic geochemistry of the basalts has also shown affinities with both the South Shetland Islands and the James Ross Island groups. Thin section work has shown some extremely fresh
basalts and intrusives, and has given an insight into some of the tuffaceous rocks which basalts and intrusives, and has given an insight into some of the tuffaceous rocks which
apparenty show both sub-aqueous and sub-ariel volcanic activity. Again more detalled
observations are needed.

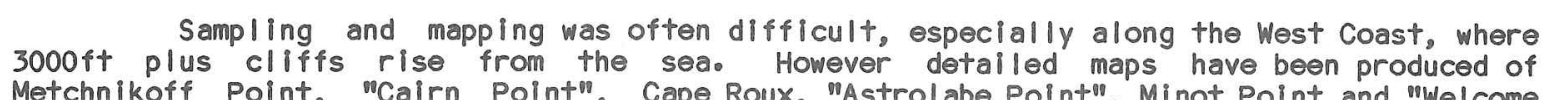

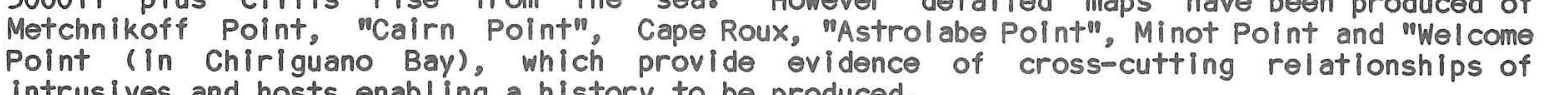

The rocks exposed on the island appear in general to become younger from south to
th cretaceous( $(2)$ conglomerates and tuffs forming the ol dest rocks found North, with Cretaceous of large, rounded, water-eroded clasts, inter-layered with $3-6$ fto bands of tuff (Indicative of a contemporaneous phase of explosive volcanlc activity) were found on the northern slopes of MtoBulcke. Samples from "Wel come Pt" should provide details of its
subsequent history, involving at least 3 later phases of basaltic intrusives. The mid-section of the island is composed of great thicknesses of coarse tuffs \&
conglomerates interlayered with basaltic lavas and sills. These overlle the conglomerate,
although the true relationships are unclear as yet Sampling was IImited both on the West although the true relationships are unclear as yet Sampling was limited both
coast and around Hill Bay, and will provide only a general outiline of this phase.

Large scale intruslves, of Andean age(8) were found at Metchnikoff Point (where an excellent vent agglomerate is present), and at "Easter I sland" "Cairn Point", Cape Roux, and These are xenolithic Quartz Diorites, although compositional variation is common; in places they show metallic sulphide mineral isation. At "Astrolabe Point" a fresh, high-level basic
intrusiv exhibits excellent cooling columns \& possible in-chamber crystal separation, and intrusiv exhibits excellent cooling columns \&
probably relates to the young lavas to the north.

At Metchnikoff point the intrusive exhibits an eroded upper surface, overlain by a coarse basaltic-rich agglomerate about $120 \mathrm{ft}^{\text {th }}$ thick. Here the agglomerates show in
depositional structures, but at "Cairn Point" \& elsewhere around the No\& NW coas crossbedding and grading are a common feature. The agglomerate thickens considerably toward
the East, and at Cape cockburn it reaches at least $950 \mathrm{~m}$ thlckness. Overlying this agglomerate in the north are young ( $1 \mathrm{~m}$ years) horizontally bedded
basaltic lava flows. These are the cap-rock of the sequence, and form characteristic bluffs, thick), vesicular, fresh and occaslonally showing good flow structures. These although reddened by Iron staining and obvlously Iron rich, are not the Magnetite flows noted by the Chileans: indeed, no evidence of such rock-types was found. The lavas includ the lava flows reach thicknesses o guer 300 ft as at Claudo Point activity. El sewher the lava flows reach thicknesses of over 300 ft, as at Claude Point \& probable vents were
found on the NE side of Virchow HIII, at Duclaux Point and Just north of it at "Vango Ridge".

Tuffs are present at up innacles Spur" and Claude Polnte on "P Innacles Spur" they waterlain. obviously explosive volcanic activity preceded the young capping lava flows, but

Faulting was difficult to define precisely due to 1 imited inland exposures. However there appear to have been 2 main phases - a NE-SW phase and a NNW-SSE phase. occurred along the faultilnes, as at Metchnikoff and "Cairn Points". Large-scale NE-SW

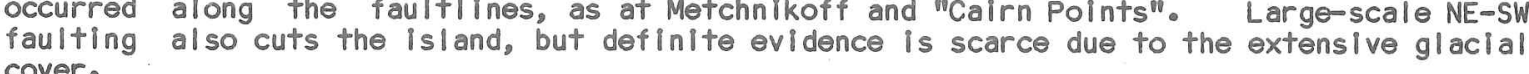

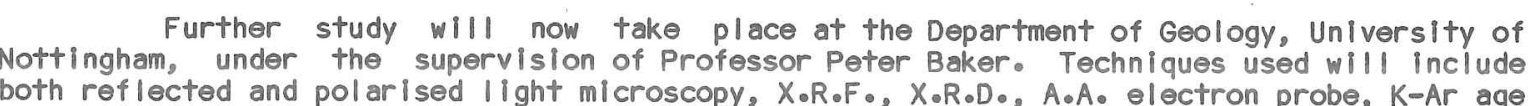

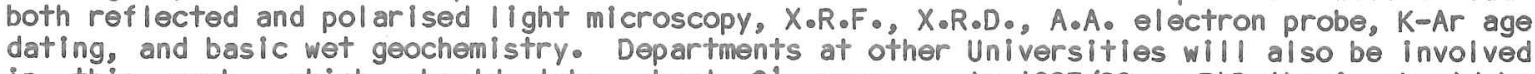
in this work. which should take about $2 \frac{12}{2}$ years 0 in $1987 / 88$ my PhD thesis should be
presented and papers published; prellminary short papers may be published earlier.

Some rudimentary fleldwork was conducted in the first two phases, but detail led work was leit intertidal phenomena in the southeast was the only qualifled geomorphologist. west and north coasts as planned. This was unfortunate, as comparison between the exposed west coast and sheltered east coast would have added value to his intertidal observations.
The only visible signs of former sea levels, and of glacler fluctuatlons were also on the
west and north coasts. Intertidal Boulder Pavementso One beach at "Dayglo Point" and three in Chiriguano Bay were the line of the longest fetch, and exhibited patterns of furrows, ridges and depressions caused by brash ice. Sheltered areas were also character ised by well-packed mosaics of
boulders. As far as possible fieldwork techniques were used which will allow collow plane-table surveys, level transects, and measurements of the orientation, size and composition of boulders and patternso The movement of tracer pebbles was examined at "spring" tides with a 25 hour period changed abruptly to "neap" tides with shorter periods, and with so little rise and fall that the beaches were never exposede Allen made. considerable contribution to the survey and sampling work. Flint will be working up the
results, with advice from Dr. Hansome other Intertidal Phenomena. Other team members observed similar intertidal boulder
barriers around the Hulot Peninsula and each side of Duperre Bay. The more exposed coasts further around the Hulot Peninsula and each side of Duperre Baye The more exposed coasts noted from Driencourt Point around to Duclaux Point \& those just south of Metchnikoff Point were extensive: however all these (except that at Duclaux Point) were wave washed, even at

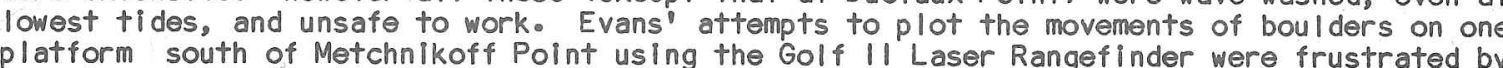
losing the tripod, and by defects in the special charging systeme some steeper cobble beaches were found, from Minot Point around to Cape Cockburno During the winter Evans
conducted a monthly survey of one such beach, at Metchnikoff Point: this should permit conducted a monthly survey of one such beach, at Metchnikoff Polnt
comparison with the relatively sheltered beaches in the southeast.

Former Sea Levels. The Second Summer Boat Party observed areas of well-sorted, wellThey occurred at various levels up to about $25-33$ ft above present sea level. Point several such features were mapped by plane table survey, and included on leve transects. A proportion of rounded and sub-rounded pebbles at about $80 \mathrm{ft}$ on the is let of Metchnikoff Point were unsorted, and no other signs of raised beaches were notedo. Rock
platforms and stacks around the northwest suggested previlous mari ine planation, at about $25 \mathrm{ft}$
and about $50 \mathrm{ft}$ above present sea level, but data were not recorded.

Former Glacier Fluctuations. Ice cover in the southeast was too extensive to reveal extensive, but very localised, on the west and northern coasts. Terminal moraines at "claude and Metchnikoff Points and at Cape Roux indicated three (or possibly four) previous south of Metchnikoff Point (and some cobbles el sewhere in the NW) could suggest glacial
south

Radiocarbon Dating of Organic Materlalo. The only organic materlals found that were that were locally abundant in till at the base of ice overlying "Welcome Point"l. They were
not found elsewhere on Brabant Islando speclmens in good conditton were collected for not tound elsewhere on Brabant islande Specimens in good condition were collected
identification: it has not yet been decided whether radiocarbon dating is desirable. 
Prlor to the departure of the first party there had been 11 title interest from outside the expedition, but the Second Summer Party wer
as part of a widespread sampling programme in the reglon.

Study of the map before had suggested that the only glacier well-suited to Evans planned a year-long study there, since it was conveniently close to the intended main base site at Humann point. However, when Humann Point proved unusable as a base, this that accumulation (and abande The four areas possibly amenable to study (Rush, Koch, Hippocrates and Lister Glaciers) would each have exhibited characteristics dependant more on aspect and local orographic
effects than on the general climatic regime. Any study would also have been prohibitively effects th
laborlous.

Datum levelling would have been possible on the bealach between the Solvays and the main Mth these accumulations of up to $5 \mathrm{ft}$ were measured over one 3 week period, and on other occasion $2 \mathrm{ft}$ eroslon was noted in two days. Repllcate levelling in later years would not therefor

Chatham Fleet Maintenance Group manufactured a corer to a pattern supplled by Dr John alde. The saga of John Gordon's corer crossing the equator four times, when it was meant to be in spitzbergen, caused at least two total sense-of-humour-fallures in Furse, Gordon for his help und to a vallo at loxpeditho tould the to record our thanks to John obtained: however this was not serious as any results would have been subject to the same uncertain local factors as the other two projects.

Paradoxically although almost entirely covered in snow and ice, Brabant Island proved totally unsuitable for routine glaciological data collectlon within the capability of amateurs. Oakley's snow-board records showed a total snowfall of $38 \mathrm{ft}$ through the
winter at Metchnikoff point, and it was almost certainly much greater on Lister and Pare Glaclers. Most of this snow was blown Into the sea within days. Local topography changed noticeably over the course of the winter to the extent that contours on a standard British $1 / 50,000$ Ordnance Survey map would have been significantly affectedo Interesting
glaciological studies into local effects are concelvable, but they would not have any gleciological studies into local effects are conceivable, but they would not have any
reglonal or climatic significance. They could only be planned and interpreted by an
experienced professional glaciologist and he would have to be a masochistic fanatic to
Meteorological work on the island had three aims. The first priority was to complle data that could be used in support of other sciences: this involved twice-daily provide forecasting information for travelling, based on measured data, experience accumulated, \& luck. The third aim was to investigate orographic modifications to alrflow, particularly the micro-scale generation of vortices \& other iee phenomena.
Mifcrometerological work was also carried out for physiology (tents \& clothing), and botany Meteorological Office \& commerclal pirms. Advice was obtained from the Meteorological A Base Metostation was set up at Metchnikoff Point, initially on the crest of the moraine, then (In March 1984 ) lower down at 180 it above sea level, in the best

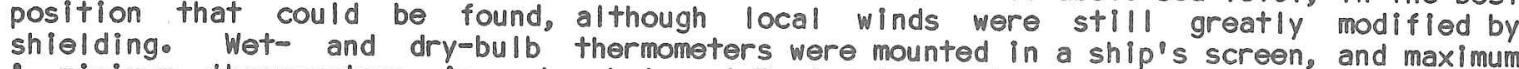
$\&$ minimum thermometers in a box below. A Porton Anemometer and windvane were mounted at 13 ft height. A Snowdon raingauge nearby was used when snowfree in summer, and snow-boards at other times. Atmospher ic pressures were recorded using a Thommen mountaineering better in basecamp, and anemometers reading up to only 65 knots were yet again shown to be Inadequate for the Antarctice A smaller station was used in october and November
at Astrolabe Point. When away from base, at least one observer took a hand-held anemometer, dry-bulb. max. \& min. thermometers. In the summer seasons (and in september) the Base Met.station was sel dom used: readings were taken at the standard times, and were corrected to sea-level, but these records in these per lods are not really comparable, due to
the variety of situations, and to the wide variation of conditions produced by local fopographic eif ects that were observed as well as height.

table of monthly records. The summers were cool and wet, reflected in the accompanying

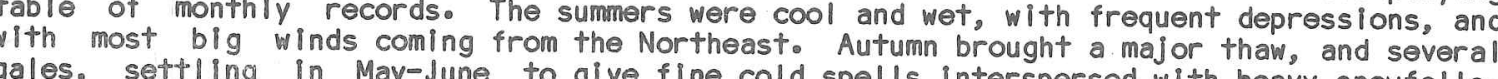
July and August brought the strongest winds at basecamp with Southwest winds in clear sk les exceeding 100 knots on several occasions. September was windy, snowy and generally windy, with both SW and NE blizzardso Unlike the high Antarctic, during the winter a total of over 38 ft of snowfall was measured, but most of it was soov blown away as spindrift. A Spring melt occurred early in December, heralding the return Different locations on the island often experlenced very different weather. The long ridge of mountains running from north to south, and the blocking effect of the notor lous for trapped cloud \& snowfall, and Fohn winds were sometimes very strong in the gap betwean Harvey Heights \& Mount Hunter, and that north of the Solvays. However strong,
truly Katabatic winds (as opposed to Fohn winds) only occurred rarely in cold anticyclonic conditions. Minot point was a remarkably calm spot with winds below 5 knots while winds, or in the lee of the Anfarctic Peninsula in NE winds. A feature under some stable conditions was low stratus from sea level up to between 1000 and $5000 \mathrm{ft}$, with clear show more rain than people experienced while travelling, but less snow, less sunshine and and very much less windo

We expected. bad weather, and we got it. Our records included 120 knot winds (in
the hills, not shown in the table), up to 32 inches snowfal and in 24 hours, and sea level barometric pressures ranging from 936 to 1028 millebars. spindrift was a major phenomenon not recorded by the standard meteorological methods average cloud cover was less than in the South Shetlands, and quite of ten the weather was
a touly

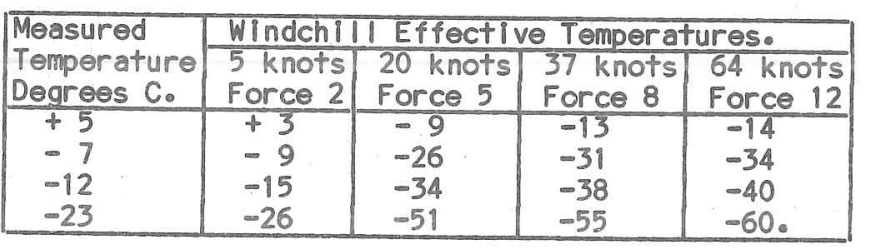

In Antarctica the effective is a more realistic measure of cold than actual temperature.
In a Gale Force 8 and actual temperature of -7, one feel
as cold as in calm at -31 . Detailed field data will be lodged with the National Meteorological Library,
Bracknello it is hoped that post-expedition analysis will yleld a couple of descriptive
papers and one concerning orographic effects, to be submitted to British lournalso 


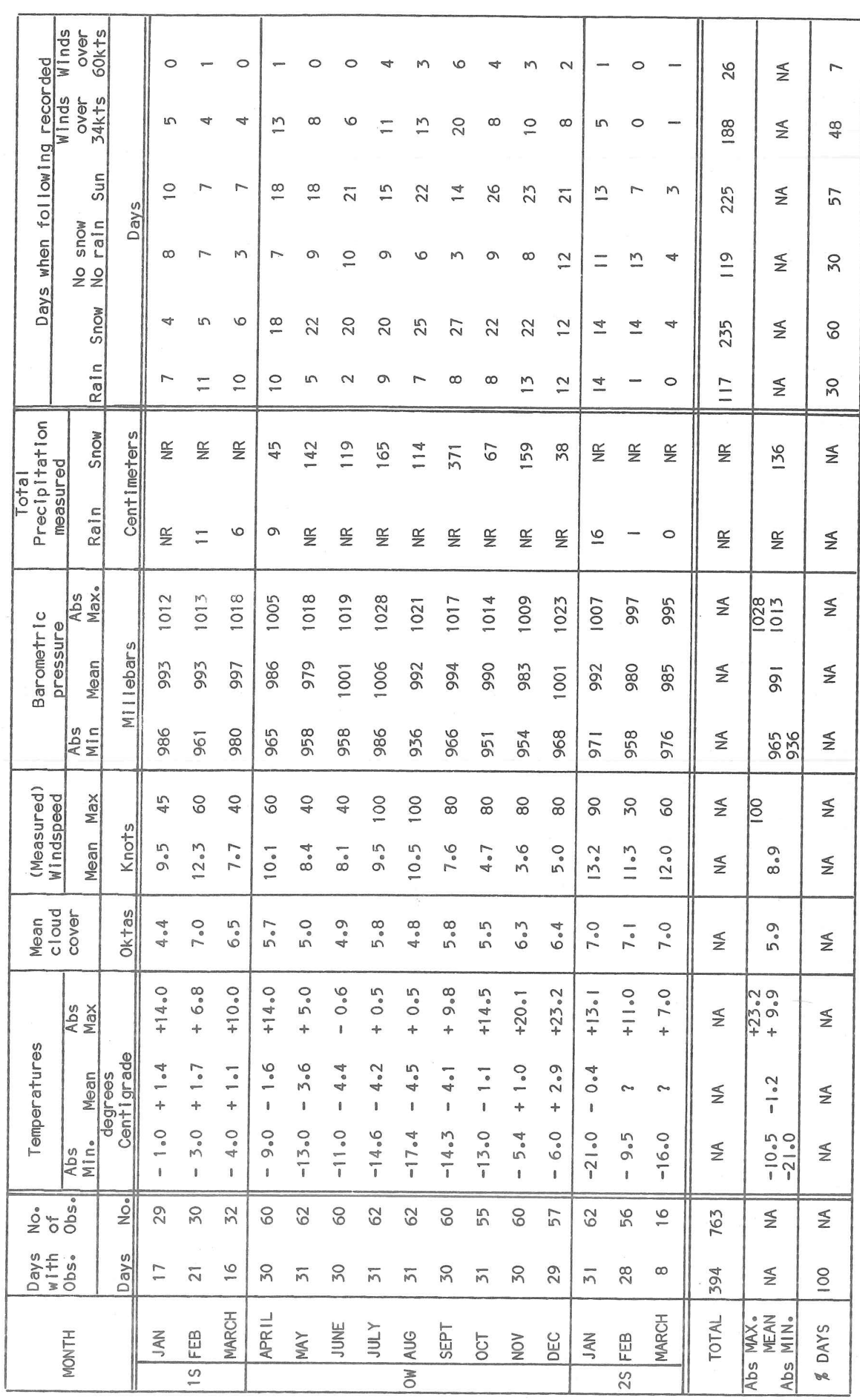

E:

E:

E:

E

E:

E

E:

E!

E:

E:

E:

E!

E:

E:

E:

E!

E!

E:

$+1$

:

\&

E

-

E $=$

E

$E=$

L

$E=$



$E=$

Survey work planned for Brabant Island was limited to producing large scale maps of particular snowfree areas as needed to support the geology, botany, terrestria

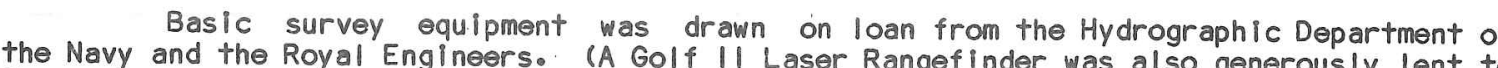
the expedition to faclilite plane table mapping, but unfortunately the battery charging arrangent

of Military Sus and Evans were each given 2 weeks pre-expedition training at the School quite adeary Survey. Despite neither having any previous survey experience, this proved There was an existing map of Brabant Is and (the Directorate of Overseas Surveys
Sheet SQ $19-20 / 4$ in Serles BAS 250) at 1/250,000 with 100 meter (c330ft) contour interval. This had been prepared in 1974, by photogrammetry, from aerlal photographs taken by Hunting a few heights, as noted below. Photostatic enlargements of the DOS map to $1 / 33,000$ wer used for most sclentific mapping, with details of snowfree areas etc being sketched in,

The most while climbing in the Solvay Mountains, Atkins found several heighting errors. The most obvious of these was Galen Peak: according to the map, this mountain should have
been the third highest on the Island, but it proved to be about 1000 ft low and two nearby peaks were higher than Galen Peak. Several other errors of 50-500 ft were discovered in the Solvays, plus two isolated errors at "Per Ardua" peak and between differences between the camp site and each summit and barometric pressures ot the height camp (by Thommen mountaineering altimeter) were recorded dally at 1000 and 2000 for later correlat on with the simultaneous meteorological records at sea level. After check-

The following local topographic maps were prepared during the expedition:

A. Metchnikoff Point was mapped at 1/2000 with 50 meter contour intervalso Atkins completed the map in about a week in January 84
using a plane table and telescopic alidade. Plane tabling proved using a plane table and telescopic al idadeo Plane tabling proved
very simple, with the advantage that results required no complicated equipment and were not subject to plotting errors. The details of the coastline and stacks
the Hunting Aerosurveys photographs.

B. "Astrolabe Point was sketch-mapped at 1/1500 with 10 meter contour intervals. Atk ins completed the map in two 2-day perlods helped by Hank inson in March and by Ringe in october using a silva sighting by Thommen alt Imeter. The resultant accuracy was adequete for was purpose required.

C. At "Cairn Point" in December 84, Ringe and Spottiswood spent two days preparing a sketch map. They also establi ished six stations using the Kern theodol ite and marked the stations for subsequent geological map. The events of March 85 prevented photogrammetri geological map. The events of Mar
Wasps undertaking the photography.

D. Minot Point was mapped at 1/1000 with 10 meter contour intervals in Helghts were obtained by Hilger Watts level and telescopic ali idade.
Hel ing

E. Welcome Point"l was mapped by Allen and Flint in February 1985 to
support geomorphology and geology studies.

F. Cape Roux East was sketch-mapped by Ringe in April \& September 84, areas were sketched by cruder visual judgement. 
Evans recorded the extent of sea ice off the north \& west coasts from April to October inclusive. No extensive floes were seen, though the sea was occaslonally covered
with broken Ice to the horlzon. I ce cover in this area has seldom been recorded in winter wo these records may be of some interest, although this was the third successive winter

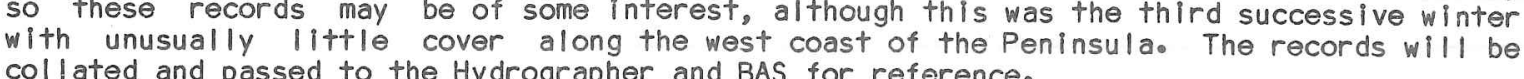
The measurement of iceberg drifts as an indicator of currents and tidal streams
was a project generated by the expedition. A Golf II Laser Rangefinder system had been very generously provided on free loan by Measurement Devices Ltd and Lasergage Ltd: this
enabled rapid direct plotting on a single plane-table which promised a high frequency of position. Metchnikoff was an excellent site, although the $9 \mathrm{~km}$ limit of range precluded plotting the bergs far out in the Bellingshausen Sea. Unfortunately the (the December thaws, and the rangefinder battery charging unit capacitor fal led, so no data were
obtalnedo since outside interest had been negligible, this fallure was not serious, but
it was disappointing.

The tidegauge was installed in the boat haven at Metchnikoff Point in March 1984 Records were obtained for 3 days before the sensor was moved by heavy seas. The equipmen site was found where boulders had fallen into the sea. 1 in mid-March the third set records was started, but some days were lost after the team changeover due to unfamillarity with the equipment; then further problems with sensor movement and air leaks developed. sensing tube was then frozen. Although no complete 18 day record had been obtained the results had allowed some comparison with the predictions for Nansen Island, the nearest Point quoted. The timings corresponded quite closely; however the range at Metchnikof seclusion of the Gerlache Strait. Observations later in wanter and spring indicated ative greater range at Metchnikoff Point. Messages sent back in winter did not reach Britain, during the esessary replacement equipment was not brought out to set the Tidegauge to work tidal conditions were found to differ from predictions at "Dayglo Point" (in the Gerlache strait) as well as in the Bellingshausen Sea at Metchnlkoff Point.

Draft amendments to the Antarctic Pllot coverage of Brabant Island are being submitted to the Hydrographer of the Navy. These are all minor, compris ing information on
boat landing sites, and inshore dangers, plus reference to the Refuge Hut left behind at

The paucity of data obtained for these projects was rather disappointing, admitted that the two failures were partly due to inadequate homework and to lack of
attention to detail on passage out and in the field, as well as to the loss of
communications through the Falklands.

attention to detail on passage out

Several projects for collection of parasite samples had been arranged. To spread
the load, fleldwork was undertaken by the var lous team members covering the host species.

These projects were all accorded low priorities, although parasitology is one of
the areas where knowledge of the Antarctic is still scanty. No permits were sought to kill hosts, but samples were taken on an opportunity basis, when fish or crabeater Seals were
collected for other projects, and when dead or badly-injured seals or birds were found.

task which collection of parasites was a cold, dirty, laborious and generally unpleasant samples collected reflects this. Nevertheless Furse, H111, Kimbrey, Oak ley \& Spottiswood each spent several days cutting up penguths, remainder of the is land, the parasite projects were abandonned at the end of the winter
phase. The notes below cover the various projects on parasites. All material collected is belng passed to the speciallsts conaris

Seals Project 4, and Birds Project 8. (Dr Andersen is working on a revision of the Three Crabeater Seals: Stomachs \& guts were examined but no parasites found. One Weddell Seal: Samples of cestodes, plus nematodes were collected from stomach and gute

Birds Project 7. (Endo parasites). No samples were obtai ned, because precedence was give to Dr Anderson for gut samples from the very few Chinstrap Penguins obtal
freshly dead birds were found before the scavenging species had opened theme

Birds Project 9. Nest material of Kelp Gulls, Sheathbills and Chinstrap Penguins was
examined, and visible organisms extracted for BAS as part of the overall terrestrial Terrestrial Invertebrates Projects 1 \& 11 . While collecting arthropods at Metchnikoff
Point free IIving ticks lxodes Uriae were found under stones near two Chinstrap Penguin
colonies. Project II was arranged to obtain further information during the Second Summer.

Seals Project 8, \& Birds Project 6. (Ectoparasites for B.M. collections). No ectoparasites were found on three Crabeater Seals searched. One tick-like creature was
collected from the anus of a dead Weddell Seal, plus skin from the anus and "armp it" of one
dead Fur Seal. No ectoparasites were found on 2 dead Chinstrap Penguins searchedo. Plans to obtain ectoparasites from live Wilsons Storm Petrels using Drione Powder were shelved, (to reduce

Marine Blology Project 4 (Fish Parasites). Kimbrey examined 15 Antarctic cod in. with nematodes: samples of these nematodes and of complete organs were preserved. Kimbrey also externally examined 4 I cefish (coaceratus) before preserving the fish whole. A fluke-like ectoparasite nearly 2 inches long was found near one specimen's eye, and some other smaller taxa around the pectoral fins, and these samples were preserved. 
During preparations we had helpful advice from Martin white at BAS, the Marine Blology Laboratory at Plymouth and others. Two trammel nets were purchased, and tried out at Dundonnel (catching almost as many crabs, and hedgehogs as fishl). Shakespeares
donated several rods and reelso

Initial attempts to catch fish by rod and line at Metchnikoff Point were
fruitless, but crabeater meat bait was tried and succoeded in catching the first fish in July. Rod and line was proved quite successful thereafter, in ith limperts and first fish in but artificial lures were never successful. The Second Summer boat party also caught
fish on rod and line at Metchnikoff Point. The Trammel nets were used successfully off ets successfully there and also of one net was lost when dragged into deepwater by sea-ice, preventing its use up the east old fishing easiest and most entertaining method of fishing, though catches were all of the cors the species (noneglecta). Spinning was not attempted. The total of fish caught was modest (none in the First Summer, 38 in winter and
48 in the Second Summer). Most were "Antarctic Cod" notothenia neglecta (of two distinct were caught in trammel nets. In the Second Summer a few small orange fish were caught: these awalt identification, but may have been the smaller size-class of noneglecta some
of which had been caught in winter.

Whole specimens have been preserved to satisfy various requirements. Basic measurements and Fin Ray Counts were taken for nearly all fish caught. 25 specimens were of gut contents, otoliths and parasites. However in a tent-based expedition like this it was probably a mistake to take on a project using preservatives that had temperature
limits within the environmental range: for this and other reasons, the fish musclo project
was not achleved.

The fishing projects were of low priority, as some work had already been done
in the Palmer Archipelago including Dall Iman Bay. However they were worthwhle, providing in the Palmer Archipelago including Dallman Bay. However they were worthwhle, providing
some results, much interest during the expedition, and also some good variety on the menue

Much work has been carried out on Antarctic plankton. During preparations it was clear that external interest was insufficient to justify any fleldwork, which would We had hoped that some simple statistical annual cycle work on the widely
distributed Antarctic IImpets would be worthwhile, but no bids were received. The three projects on marine invertebrates were very minor, and only a few display samples were
obtained. In the event a varlety of marine algae were present, both in situ and as flotsams apart from 1 impets and some small crustacea the only invertebrates observed were very fow starfish and jellyfish, plus some barnacles on $30 \mathrm{ft}$ Kel stems cast up as flotsam.
Flint also found some elongated $8-10 \mathrm{~cm}$ bivalve shells in glacial till at Chiriguano Bay.

Collection of invertebrates from the simple Antarctic terrestrial ecosystem can
taken by unqualifled amateurs, provided they are prepared to do a lot of homework be undertaken by unqualifled amateurs, provided they are prepared to do a lot of homework
beforehand, and to persevere meticulously with the rather laborious flel dwork. Therefore projects were actively sought. Collections have been made up and down the Antarctic
Peninsula but knowledge of the distribution of some orders is still remarkably scy Brabant island was a complete blank on the map for all orders. Although the very limited terrestrial fauna varies $11+t$ le. through the maritime Antarctic, further definition of the variations is required and Brabant Island appeared to be in the border area between the difficulty in obtaining specimens from the Antarctic away from permanently manned bases as BAS scientists are fully occupied on their own projects. Consequently approaches to Universities etc ellcited several keen responses and a variety of collecting projects were
arranged. in addition simple pilot studies on the annual cycles and populatlons of some

Each project Involved collections from widespread sites on the island. A varlety
of habitats were also to be sampled, including: moss turf; wet moss carpet; grass roots: Of habitats were also to be sampled, including: moss turf; wet moss carpet; grass roots;
II chens; algae; ahumic "soilli" with and without organic fouling by penguins (and other
birds); freshwater. "Ppooter" The larger arthropods were searched for by eye, collected using a brush, or a substrates were knife, and preserved in alcoholo. For Tardigrada \& Rotifera samples of samples were simply collected and preserved in Bouins Fixative, without any examination trays flooded processo Nematode collections involved a lengthy extraction process using before preservation in a solution of Formalin and Acetic Acldo This process proved difficult in a tent: a special "bugs tent" was set up during the First summer, but extractions of nematodes were limited in the two later phases.
Smaller arthropods, together with other organisms virtually invisible to the naked eye were extracted from habitat samples using funnel elements provided by York University. Instead of the large and elaborate apparatus, with electric heating above and dustbin with" 9 funnel elements, a simple "dalek" arrangement was made from a plastic cooled below by melting ice. Live organisms moved through the habitat sample in each funnel downward away from the heat, until falling through the gauze, to be collected in water. The First summer samples indicated that periods of extraction by this is to be longer than the 2 days employed. By the time this was reall sed, much of the winter extracting had already been completed, but longer per lods were used thereafter whenever practical, and it is hoped that more complete and representative samples will have
resuledo. This "dalek" extractor was a simple device and is suitable for mobile
expeditions, provided longer extraction times are shown to be effective.

Collectlons were made from the following sites:

"inter: Metchnikoff Point; "Cairn Point" and "Astrolabe Point" (approx 350 samples). Second Summer: Metchnikoff and Minot Points; chiriguano Bay; Koch Glacier; "Well coome Point".
"Dayglo Point" and Pinel Polnt.

Population studies of conspicuous arthropods were undertaken at Metchnikoff Point,
ree representative sample plots were taped out by Morris and collections made at where three representative sample plots were taped out by Morris and collections made at
about monthly intervals through the year. Examination and identification/analysis of material collected will take some times
and the loss of the First summer samples for several months in transit delayed initial examinations. Nevertheless, from the observed occurrence of larger arthropods in the field vegetated northwestern points such as Metchnikoff, "Astrol abe" and Minot Points. The east coast is in contract biologically sparse, although springtails, a few larvae of the wingless
midge and several species of mite were found in the area around chiriguano Bay $9 \mathrm{~mm}$ long During arthropod population studies in the winter, mite-like creatures up to about colonies. From attributed these to the obscure family Opilloacaridae, known only from varlous sites around the Indian Ocean, from Madagascar to New Zealand, and raising hopes that the expedition had However after the lost. larvae and eggs of the Tick lxodes uriae, which is known from about 47 sites in both the Arctic and Antarctic. It appears to be parasitic on birds, but 1ittle is known of its life
history: so the expeditions observations will be of interest. though not so dramatically
exciting as we came to belleve in midtwinter. 
Botanical sampling and surveys require greater knowledge than does collecting and judicial selection of suitable sites and methods for more detalled work. Fortunately team members with relevant training and/or abilities were avallable in each party.

Vegetation was generally sparse, particularly on the east and south coasts where points (notably Minot Point, "Astrolabe Point" and Claude Point), unexpectedly rich stands surprising profusion. and only very small areas of poorly developed moss carpet. Away from the few rich coastal points vegetation was mainly restricted to lichens, with some small moss cushlons. Even
on the few exposed outcrops there was scarcely any vegetation inland; nevertheless lichens
were found at two east side sites at 3000 ft.

Collections of mosses and substrates, for analys is of mineral contents, were made
hase. Collections of likely habitats for microfungi (including species predacious colos moulted sealskin, penguin guano and other attractive material. These coilections will The only toadstool-type macrofungl found were some small clusters of brown
Agarics collected from a grasssward at Metchnikoff Point in April and January and from
varlous moss associations on Minot point in February The main aim was to determine the range of plants species present, and their
distribution around the is and by collection and preservation of specimens for subsequent Terrestrial Ecology at Edinburgh, plus some possibly held by BAS at Cambridge. Representative collections, covering mosses, Iichens, algae (and liverworts?) were made

First Summer, Cape Roux East, "Cairn Point", "skua Bluffn, Metchnikoff Point,

Winter. Metchnikoff Point and "Astrolabe Point".

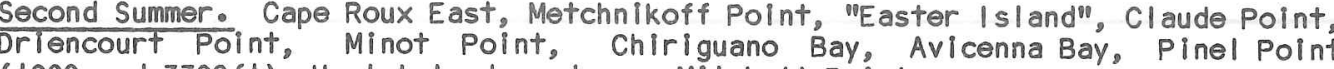
and, and near Mitchell pointo

Moffat in the Second Summer Boat Party was able to make particularly widespread
observations. The only botanically rich area not visited was Humann Point.

In all three seasons more detailed observations were made in particular areas.

In the First Summer, (using 1:2000 maps produced by Atkins), Hank inson prepared int in March, making detalled records of soclations in several areas where Antarctic Hair

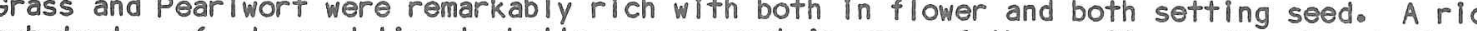

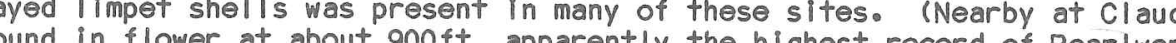
in the Antarctic).

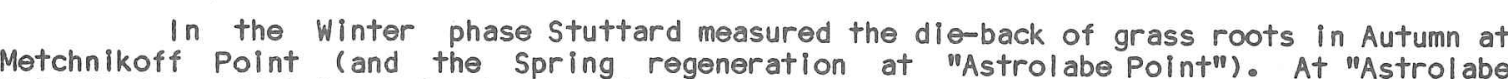
Point", from mid October to the end of November, he recorded detal led observations of plant st the same time he and oakley recorded progressive exposure as the snow melted. 列 flowering plants on total sunshine was evident in the fleld, both being confined to northfacing slopes, and being replaced by mosses under the more persistent snow banks. The

In the Second Summer, Moffat made a detailed study of the flora at Minot Point
in February and March. This was by far the richest area on the is and: a total of 37 species were identified with luxurlant stands of mosses and both flowering plants on the wind. A quantitative ecological survey was carried out using the classifications developed by Dr.RIL Smith for signy island, and referred to the 1:2000 map produced by Hughes. Moffat intends to produce a paper for publication, comparing this site with other areas
the Maritime Antarctic, and DFoRIL Smith of BAS has of fered to help and advise on this.

Seal counts were made regularly at Metchnikoff Point and Seals were counted at all
other coastal areas visited to give an indication of the local populations and distribution. observations on moult, breeding and socilal behavilour were also recorded.
The one high priority project was colloction of Crabeter seals stomach contents through the winter, for statistical analysis, as part of the BAS contribution to the International BIOMASS Project. (Seals" digestion is rapid, and sampling by BAS in summer had obtained little material: it was expected that larger food samples would be obtained as the animals built up reserves for the beeeding season). Unfortunately there was i intle
pack lce, bringing very few Crabeaters to Mretchikoff Point, and the three seais shot in May
and June contained nothing in their stomachs. Some samples of skulls and skeletons were obtained from these three Crabeaters
and from Fur and Weddell seals found deade Cleaning and pack ing of the skeletons proved The three crabeaters rock pools avail able to exploit the scavenging crustracea. were remarkably free of infestation. In contrast several endoparas ites were collected from The blubber sampling was planned for late in the Winter, but no more Crabeaters
hauled out then, so this low priority project was abandonned. Collections of moulted hair or skin were made from 3 species for examination of mi rerofunglo
The seal counts and concurrent observations provided to BAs for counterence. No Ross Seals were sighted but the other 5 Antarctic species
were all recorded.

Elephant Seals. (Mirounga leonina). At Metchnikoff Point at ieast one was seen each

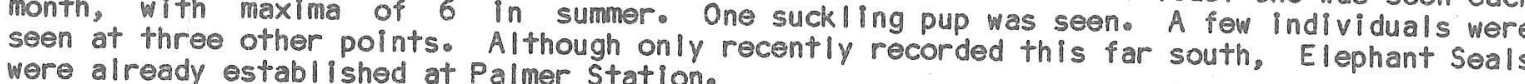

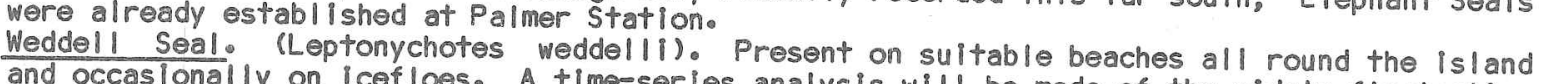
counts at Metchnikoff Point, where the largest population on the is island reached naximum of 60 in January. Surprisingly fow pups were soen.

in March and April. This scarcity was attributed to the lack of icefloes this with none Breeding behaviour was observed in October but no pups were seen. More were seen in sumer on icefloes around the east coast particularly in Gerlache Strait. Freud Passage and Bouquet
Bay. Leopard Seal. (Hydrurga leptonyx). A few were seen in winter associated with sea ice. In
summer few were seen on the north and west coasts, but more off the south and east coasts particularly in Froud Passage. No pups were seen, nor breeding behaviour Fur Sealso (Arctocephalus gazella). In each Summer a large influx occurredo From early majority were around the northwest coast, with maxima of 950 and c700 at Metchnikoff point, individuals suggested emigration from south Georgla, where a "ikrill famine" pale sandy next summer influmbers dwindled through the winter, with none seen in November, before the next summer influx began in December. No pupping nor breeding behaviour was seen, although
some very small animals were belleved to be moulted pups. The NW coast must be a potential
site for further southward expansion of their breeding range

WHALES

Seen more frequintingly fow whales were sighted from the is and. However they were or two were usually sighted each day, with a maximum of 12 Humpbacks in the Gerlache Strait no skulls or skeletons were found ashore, and there was no evilence of any past whaling
activities. Humpbacked Whales. (Megaptera novae-angliae). This was the most commonly identifled, occasionally seen off all parts of the coast, but most commonly in the Gerlache Strait. The latest sighting was in mid March; a couple visited Metchnikoff Point in August but Rorquals: Some seen in Daliman Bay and the Gerlache Strait in the Second Southern Right Whale. (Eubalaena glaclalis). Two individuals were sighted in the Second
Summer. This specles appears to be recovering and possibly extending its range southwardd 
Our primary alm was a simple breeding census: most (but not all) of the coastal areas were covered. Breeding populations were
the varlety of species was greater than expected.

Information was obtalned on the timing of events through the full annual cycles of resident species. Breeding dates of several specis should this should provide interesting comparisons, particularly in conjunction with the different
changes recorded at Arctowski and Palmer Base and with data from Signy I Iland otco multivarlate factor analysis is now planned using the expeditions PC Computer, provided
relevant data from other sites can be obtainede.

Records were kept of feeding, flocking and breeding habits through the year.
tion of our winter basecamp at Metchnikoff point provided better opportunities The position of baseso Large casting movements of several petrel species were recordede Recover les were
made of four Gentoo Penguins, two Chinstrap Penguins and one Sheathbill marked by the USARP. Some material was collected for several minor projects (Numbers 5,8,9 and 10).
This is simply being passed to the relevant speclalists. Preliminary breeding census results will be passed to BAS for their forthcoming
publication on breeding birds of the Peninsula regions detalled maps and supporting notes
will be provided later to BAS, for reference. A general paper on the birds of Brabant Island in relation to the surrounding reglon will beneral paper on the birds of Brabant
followitted for publication. The outllines the observed status of specles.

Blue-eyed Shag. $P_{0}$ atriceps. Local ised breeder in small numbers. Large winter flocks. Chinstrap Pengui Ao forsterl. (The only Antarctic breeding specles not recorded). Aentoo Pengulno Popapua. Non breederso Reverse migrants in Autumno Occasional in winter. Macaroni Penguin E.chrysolophus. Very few non breeding visitors, in sumer only.

Light-mantled Sooty Albatross. Popal pebrata. (Only certain record 50 miles offshore)

Glack-browed Albatrosse Domelanophr is. Regular of íshore (occaslonally inshore) summer only. Grey-headed Albatross. D.chrysostoma. Several "probable le sightings of fshore in summer.
Glant Petrel. Mogiganteus. Regular in small numbers throughout year, no breeding colonies. Antarctic Fulmar. Foglaclaloi des. Locallsed breeder. Frequently seen inshore in summer, Cape Plgeon. D. capensis. Patchy breeder in north \& westo Scarce in midwinter.

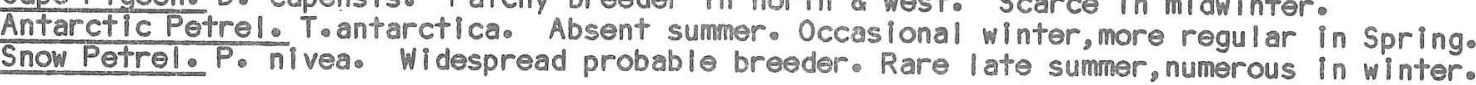

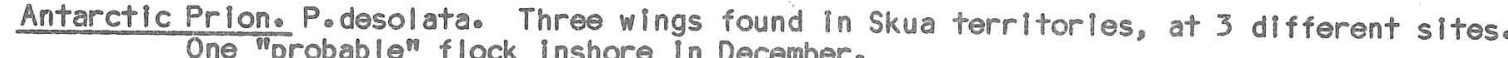
Blue Petrel. Hocaerulia. Conly certain records $90 \mathrm{mil}$ les of fshore in summer but the Black-bellied Storm Petrelo Fotropica. Scarce sumner visitor, breeding strongly suspected Wilsons Storm Petrel.0.oceanicus. Widespread numerous breeder. Absent in winter.

Brown Skuo C.Solonnbergi. Scarce summer visitor, a very few bred. Absent in winter.
South Polar Skuap Cosemaccormicki. Patehy but widespread breeder. Absent in winter. Kolp Gull. Lodominicanus. Widespread resident in small numbers. Autumn migranto Antarctic Terno Sovittata. Widespread breeder in small numbers. Roosting flocks

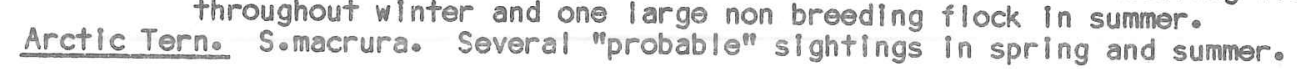

Sheathbill. C.alba. Very localised breeder. Similar winter population widely dispersed.
Physiological studies of man in the cold are common. What makes this expedition's night, and all spent over nine months doing so. investigations were aimed first at determining whether man's fluid halance showed accl imatisation, if there was adequate cold monitored and thirdly the microclimatology of clothing tents and other shelters wer Investigated. This work was carried out as a major project of the Institute of Naval Madicine, with the

Equipment consisted of a Hawksley micro-haematocrit centrifuge, a Christ hand callpers, a Grant CR50 45-channel datalogger, Grant DB9U 9-channel intermittent chart recorder, 26 Grant thermistors, an Aga Thermopoint 80 infra-red temperature gun', an journey down, but other equipment worked very well, particularly that made by Grant instruments.

The detalled results have yet to be fully analysed, a task which may take several years even with IBM's microcomputer. However, it is clear al ready that the members of the winter team are the first subjects ever to have shown unequivocal evidence of major weoks unt Il August and wired up for an average of 60 hours to record skin and clothing temperatures. They collected their urine over 24 hour perlods and logged activities, perception of warmth, comfort and thirst, and fluid intake at regular intervals over the winter months.

It has been reported that men exercising in the cold can become very dehydrated within days, leading to thicker blood, which in turn makes frostbite more likely. During because when cold overnight the body pushes out more water in the urine). In May mos samples showed typical dehydration. This night-time cold diuresis had almost disappeared by Julys by then blood PCV's had returned to normal, demonstrating accl imat Isation. Skin temperatures and mi crometeorological data confirmed that there was a marked cold stimulus at night 45 degreos $C$ above amblentl.

The story is but partially unfolded: a large amount of data, blood and urine samples are being analysed in UK, at RNH Haslar, and then numerical analysis will be few years in order to present the results. Undoubtedly more interesting and useful facts 

I solation of a small group of men, living in hard, cold conditions and under
physleal stress appeared to offer opportunities for studies. Approaches to psychologists thid porsonnel research estrablishments in all three Servlces produced negative responses.
riowerer Hankinson found several very interested outside researchers, while Morr is and Furse riovever Hank inson found several very interested outside researchers, whil
each gerierated their oun studies. The foll lowing studies were undiertaken.

1. Effects of cold Stress. This was planned to correlate with a long term study at memory. Unfortunately the Reaction Tester was provided with a bartrery pack which neaded boosting at low temperatures and was unusable after the generator falled. The few results was also badly reduced by poor visiblity of the Odd/Even num thore than the meno Permance

2. Changes in Circadian Rhythms. This was planned to correlate with a study of sloep tents, without the regular timetables of a BAS base hut, in the abnormal IIght/dark cycles of Antarctic summer and winter, would provide ideal conditions to assess free-running Sltep time, duration and quality, and whether self waking or not, with notes on inf i bate, external factors. The 5482 man-nights covered provided over 38,000 bits of raw data which was passed to Dr folkard for analysis. However our subjective impression was that sleøp dally travelling plans, except for one short period in basecamp before in dwinter, the many toam member's began working late and waking late. 3. Pleasures/Miseries/Cravings/Dreadso Furse wrote a questionnaire which was completed
periodically by all team members, ranking their top ten pleasures, \& top ten miser les etco After pilot trials in the First Summer this study concentrated on the Winter Party who In July as a consistency check. It is planned to analyse the results on the expedition's IBM PC computer. Examination of the results already suggests definite group trends over the 9 months, isome ramp changes, some temporary ones, and some end-effects) and also qualifications, practical skills, individual tasks, and exploratory subgroups).

Ranked top overall were: Pleasures - Warm sleeping bag. insecure tent equal. cravings - Female company, sex and family affection equal.

Furse will canvass for a professional psychologist interested in collaborating on the

4. Control of Circadian Rhythms by Melatonino Recent research on sheep indicates that 政 logs providing the supporting data. This trial was discontinued in the Winter phase, due to 5. Stress-related Healtho Short general questionnaires were completed by team members.
Morris belleves that the results show definite trends, and will be assessing their
significance.

6. Social Interactions Within an Isolated Group. This expedition provided an excellent in the First summer. He completed the questionnalire himself in private interviews conducted periodically. The Winter Team all agreed to this study, with Stuttard voted in as the producing group soclograms, he will test the signifficance of var lous factors likely to
influence the soclal structure. Use of codeletters will preserve anonymity (although team Influence the soclal structure. Use of codeletters will preserve anonymity (although team
members expect to be able to identify everyonel) This project interrelates with Project
No.3, and some cross-analysis may be undertaken.
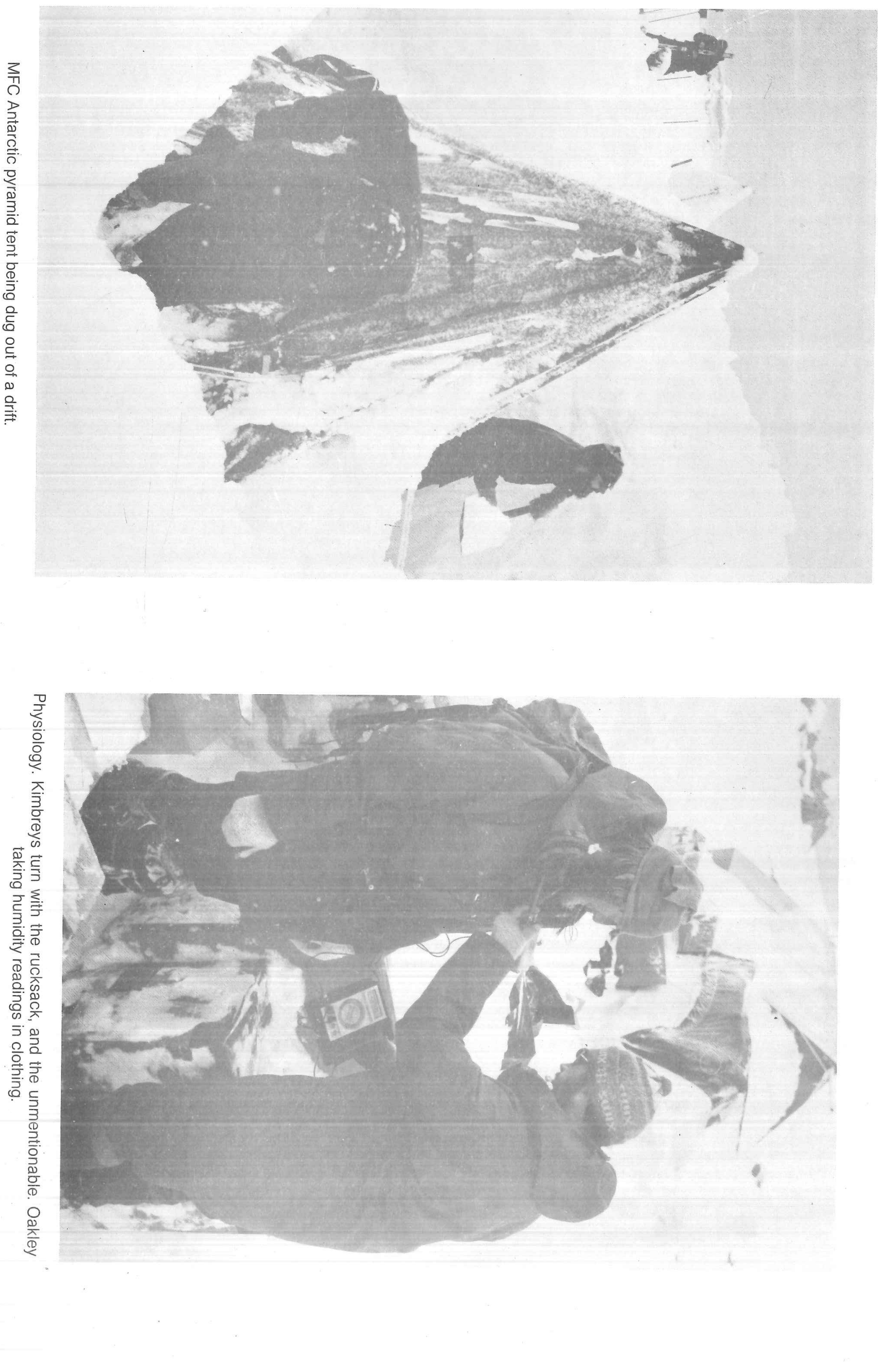


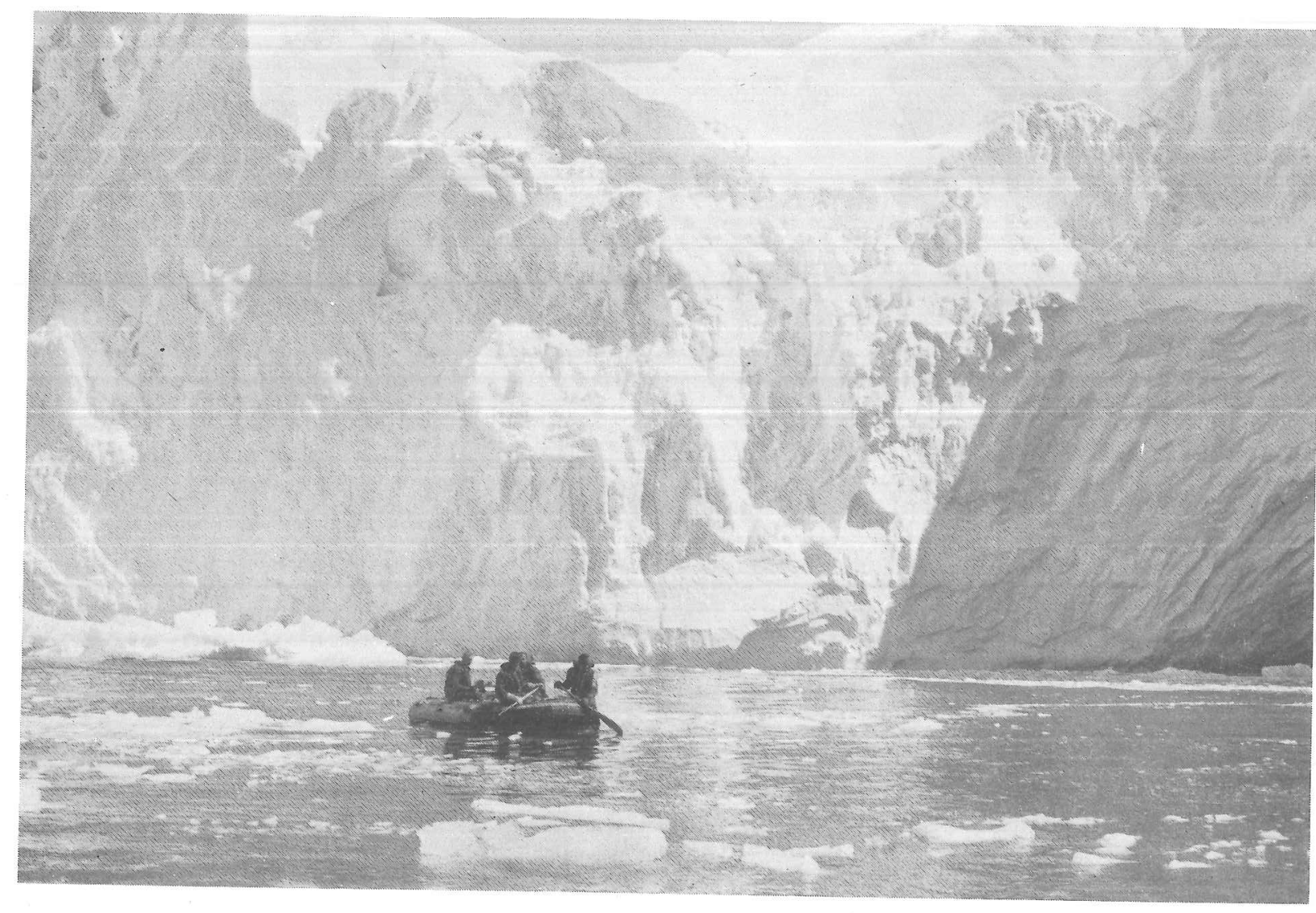

Circumnavigation. Boats in scattered brash off the East coast of Brabant Island.

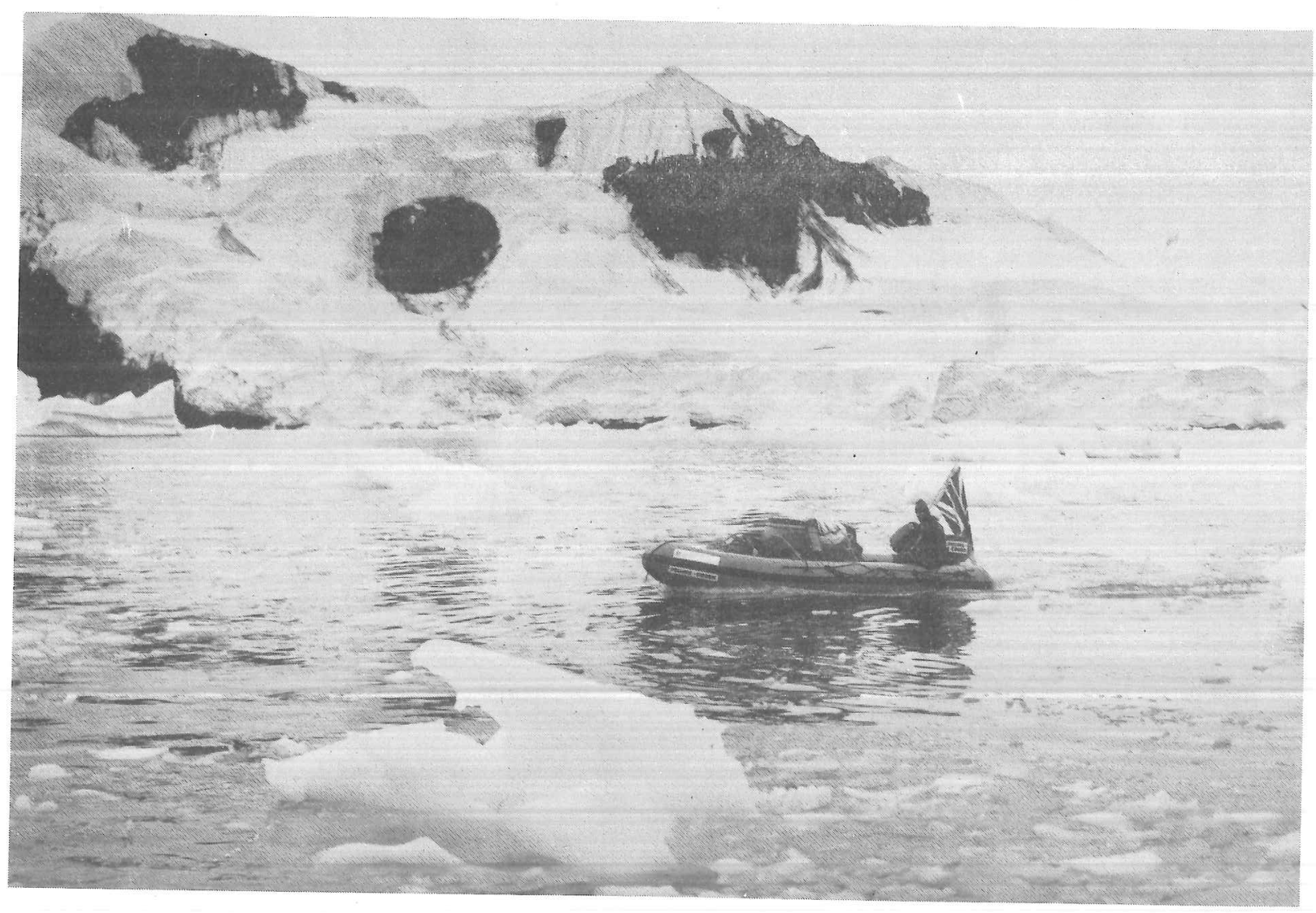

Purpose. The main alm was to pass information to and from the expedition rearlink in
Britaln at intervals of about a weok. The secondary aim was to have contact between
separate parties whille on the island.

Equipment. Neither the team nor individual team members could obtain any radios on loan
withln the Services. HIIl approached two Plessey Electronic Systems Ltd lent the expedition three PRC320 "Clansman"
HF Transceiver setso These are the main British Army manpack set: they proved utterly
reliable throughout the 15 months, despite being subjected to low tempertures high humidity in tent's, rain, sea-spray, and rough useage. The comments below refer to these sets, which provided our only external communication and our main internal one.
Whip and end-fed aerlals were taken, but seldom usedo Dipoles cut to proved most effective and convenient using a mast in basecamp, but skisticks or bamboo marker wands proved satisfactory when travelli ing. Headsets and handsets were both used. in the Second Summer Sol ar Panels from the SAS proved very effective. When travell Ing i amp batteries were used with a hand charger: this proved very relliable, although thel $1 \frac{1}{2}$ hours cranking was required prior to schedules. talkies", and lent us three old PRM $4160 \mathrm{~T}$ sets. These line-ofesight sets were Occasionally used between basecamp and local parties, and between the skidoo team and route-finding ski parties. Rechargeable Ni-Cd batterles proved satisfactory, but when the generator fail led, Spare headsets and handsets were held in basecampo The main sets needed no
repairs, but discontinuity problems occurred sometimes in the handsets, coaxial antennae
cables aerials and the various assoclated connectors. Losses of communications for over 2 weeks in November and February were initially attributed to "blind spots" but eventually

Deployment of HF Setso The difficulties of overland travel were underestimated in the another at "Astrolabe Point" in March. Consequently, al though one was normally avall ible for external communications, the Winter Party did not have two sets for internal of the sets with the Southern Party having o4. Metchnikoff. Point). Intercommunication betwe many occasions in the first two phases, and occasionally also in the last phasey missed on

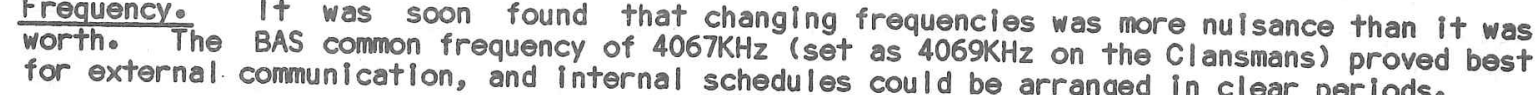

External Contacts. Our main contact was with Faraday Base; the base operators were very with Mike at Palmer Station and Steve at SI gny Island. Only very occas lonally was 2 way communications with the Falk lands possible, but we were always able to hear station WPC
clearly from Stanley. The following places were contacted, (in order of useage): BAS Faraday Base ( $87 \mathrm{mil}$ les). Good 2-way comms almost always.

AAS Signy Island Base (552 miles). Usually good reception; transmission over $50 \%$ good. BAS Rothera Base (290 mil mis). USually reasonable reception, transmission nearly $50 \%$ good
Falklands Station VPC (886 mil les). Usually good reception, transmission very seldom Bird Island, South Georgia (c1200 miles). Occasional reasonable reception. HMS Endurance (1-300 mi les). 2-way comms often good, but erratico Pol ish Arctowski Base (ec160 miles). Reasonable 2-way comms. several times. BAS Han Rodol fo Marsh Base (c80 miles). Good 2-way comms a couple of times. RRS Bransfield, RV Hero, RRS John BIscoe, RRS DIscovery, MV Polar DUke successful once. occasionally contacted when in the vicinity and we talked once with MS Lindblad Explore The expedith Georgla and once with a Russian Base somewhere.

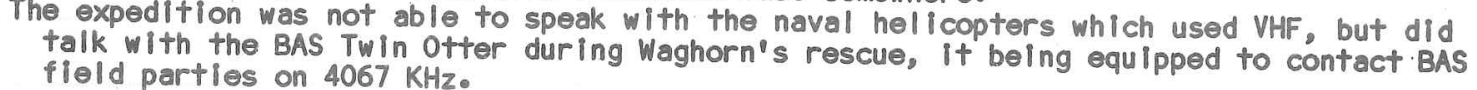


Links with Britain. BAS had agreed to pass one 100 word bul letin per week. These were radioed to Faraday, who transmitted them in facsimlle by satellite to BAS Cambridge, who
in turn sent them to DNPTS by post or telex. A distribution "treen ( to Next of KIn, the Sunday Telegraph and the local PR Off (cer) had been pre-arrangedo However DNPTS were short to distribute: with hindsight it would have been better to arrange forwarding ink officer BAS Cambridge to the Expedition Rearlink. Otherwise this arrangement worked very wel flled them (1). Short outward minger scientific messages back, however longer logistic or personal messages were not allowedoer In Aprll Palmer Station agreed to send 250 word messages back by radio to the increased and after May only one (personal) message went this way, untll a resumption in In June Lumsden arranged a further two-way link through Station VPC in Stanley,
after CBFFI had expressed interest. During the remaining 6 months of the winter each tear member sent one personal message home by this route, and a dozen logistic messages were were received by this route, and it wasn't untll December that we real ised that messages majority of our messages, although received and copled in the Falklands, had somenow never reached addressees in Britain. Apart from causing misunderstandings in parall lol traffic ic
over the BAS route, these lost messages handicapped the Second Summer Party's equipment planning and the philatelic arrangenents.

VHF Setso Light modern walkle-talkies powered by expendable Duracell batteries would have

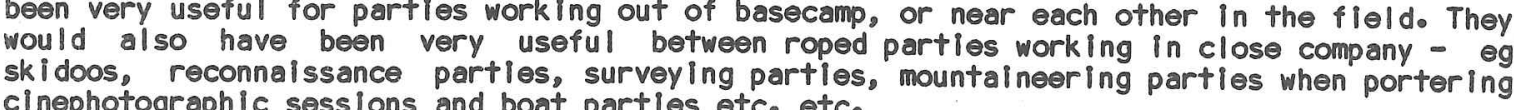

Summary. The radios we took were invaluable to us, even though we did not properly
explot them for internal communications, and despite breakdowns and delays in the routelng of messages back to Britain. Recommendationo If Service radios are not avallable and costs need to be minimised, an
expentitlon Iike this would be well advised to take just one TX/RX set capable of 2 -way
communicatlons with one nearby base. This would be left in basecamp possibly with communications with one nearby base. This would be left in basecamp, possibly with a spare
set. Adequate internal communications between parties should usually be possible using smail compact VHF sets such as CB radios. All of these could be powered by expendab!
E

E:

E:

E

E

E

E

E:

E:

E:III

E!

E!

E!

E!

E:

E!

E!

E III

E:

E ii]

E

E:

․ III

E

디

$E=$

E

E 3

E.

$E=$

It was considered essential to have a doctor to cover the Winter phase, and have one in each Summer phase. As no Service doctor was avallable for had been trained as Medical Assistants, and several were qualified in First Aido. Each screening carried out, prior to departure. A note was made of blood groups, and medical matching was required, and all received a thorough dental work-up. All team members reaived advanced first aid instruction during travel to the island, which proved its worth
particularly in the second Summer. Before some long isolated trips selected individuals
were given a dental brlef and temporary filler.

The problems posed by the expedition included the environment, the extreme
Ilmitations to nursing and care facilities, the difficulty of moving casualties, the need for moblility of equipment, and the Impossibli ity of speedy evacuation for most of the time. serious old the environment make minor degrees of cold injury universal, but it posed more falls, or other sking and climbing accidents. As a result, a very comprehensive base surgical procedure to be attempted, all traumatic conditt and books to enable almost any covered, and all necessary dentistry to be carried out. Small portable kits were made up for pulk partles, and larger rucksack unt for skidoo parties. The aim was that such partles would have sufficient to carry out immediate care whilst evacuating the casualty
to base in a pulk. Almost all of this was supplied by DMED Ludgershall, with a little
support from some drug companies.

First Summer:
in hignificant injuries were confined to. Hank inson who required 9 stitches
in scalp at Valparaiso, and 3 in his thumb in February. Blisters from Valluga boots were very common. Most team members suffered mild frostbite (continuing numbness) of monoxide poisoning occurred in at least one tente The medical problem was severe bronchitis suffered by Trathen in March, he having been the Winter: To our delight, there were no serious injuries in the winter and surprisingly few dental paln cases. Only one of the team required suturing: (Kimbrey who stabbed treated successfully with tincture of benzoin: however Ringe suffered from severe and infected erosions on his shins, and Kimbrey had a transient septicaemia following deeply SAS elephant SAS elephan needle was worse than the lacerations. Mild carbon monoxide poisoning was frostbite was universal in the fingers and frequent in the toeso In contrast anal and rectal problems were mintma. Although up to a dozen finings were lost by one ol der team temporary fillings with COLTOSOL or CAVIT sometimes with preparatory DYCAL lining the to usually required renewal every five to eight weekso Sadly Evans developed a mild duodenal ulcer during the late winter which worsened in september and he was eventually evacuated in

Second Summer: The third team were less fortunate with respect to injurles. On the ight knee was crushed against a Will ams dlagnosed torn Iigaments or a fracture and applied a After nursing by Ball, February at Queen Elizabeth Military Hospital, woolwich acuated on 30 th January and on 9 th tiblal plateau by 3 screws. On 21 st February Waghorn required 16 stitches to heal a deep six inch long Fur seal bite in his thigh: intramuscular and oral antiblotics were femur "Cushing Col"; after first ald by Clements he spent 5 days with the broken leg strapped to to the other by pieces of climbing harness, with only one initial syrette of omnipon, plus 19th March a RN Hospital Has ar her nall and to clean the break. Blisters were again a problem and incapacitated Greenway. Lesser problems included one infected finger, a lost dental filling replaced by "Cavit",

Further detalls of equipment and problems are given in a more detal led report
lodged with the RGS and avail able from Surgeon Lt Oakley RN, at INM, Alverstoke, Gosport,

lodged with the RGS and available from Surgeon L+ Oak ley RN, at INM, Alverstoke, Gosport,
Hants POI2 $20 \mathrm{~L}$. Anecdotal material will be published by medical journals in due course,
as well as a summary report covering aspects of the overwintering and canoeingo 
78 Appendix $2 C$

7 In 1912 the 6 man Northern Party of Scott's expedition led by Campbell, survived Dalgliesh, stonehouse and Jones spent the three midwinter months in tents on the Dion in tents at 66S. In 1957 some of the TransAntarctic Expedition spent part of the winter and other expeditions have moved in every month of the year. However no previous expedition

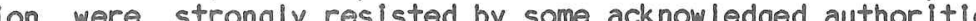
because we planned to winter in tents. Lucklly Sir Vivian Fuchs, David Dalgl iesh and
Bernard stonehouse supported our plans, and finally Vice Admiral sir John Harrison with Bernard Stonehouse supported
David Dalgliesh won us approval.

We lived in tents throughout the 15 months, except for snowholes used
for 2-6 days (once for 12 days) and igloos once for up to 6 days. A $10 \times 6 \mathrm{ft}$ cardboard shed was erected at Metchnikoff Point in March as a laboratory, casualty station and meeting place (sometimes with a wee nip to keep out the colds): however this hut was never slept in, nor was anyone greatly tempted to do so, as it was colder than the tents.
A small skidoo garage was also built out of stores boxes at base camp, but only used for A small skidoo garage was also bullt out of stores boxes at base camp, but onty used this did serve its purpose as a casualty station when Greenway spent the only 5 nights indoors on Brabant Is land with a fractured lego, We learnt quite a lot about camping over the 15
months, particularly about living in small, light tents which could be carried on rucksacks: months, particularly about living in smali, ight tents which could be carried on
some of us spent over 6 months in such 1 ittile tents, in all months of the year.

by BAS. Our main basecamp tents were two man Antarctic Pyramids from MFC Survival as used pitching them in high winds: a storm guy on the apex would have solved this. During the winter months some of us dug a snow trench down the centre of the tent, creating a sleeping
bench on each side. This all lowed us to sit with our foet in the trench, and facilitated entry and exit through the tunnel door. Our camp was divided over trenches, because it the dark days of winter we had time to make our pyramids homely. Comfort was largely due to our Tilley lamps, which burnt for most of the time, giving both heat and lighte. Wet
gloves and socks dried well hanging alongside our breadmix, proving in the apex of the
tent. These tents were too heavy and bulky for pulks, so we never took them in the tento. These tents were too heavy and bulky for p
mountains, but they made basecamp feol like a secure home.

Wild Country Super Nova domes proved to be our number one tents for travelling. They were a very convenient and comfortable tents for two men to live ino We also used them as $3-$ man tents quite offen (and once 4 men); as such they were reasonable, but rather
inconvenient when three shared for long periods. Three men per tent saved fuel. However two per tent was preferredo A 6 man party in the mountains with 3 tents could repair one and still be comfortable; starting with three per tent gave no such margin.
The Super Nova was easy to erect with two people, except in a blow. In anything more than a strong breeze, the poles tended to break while the tent was being erected Another big problem with the poles was that, in very cold weather, the connecting elastic
froze in its extended states and the surplus of elastic had to be fed into the last section of the pole: - this could not be done wearing gloves, and more than once the elastic was
cut, as both feeling in our fingers and patience deserted us. cut, as both feeling in our fingers and patience deserted us.
At first we simply made a flat platform and pitched the tent. The dome shape made a beautiful windscoop keeping the entrance clear even with $6 \mathrm{ft}$ of snowfall. However we soon found that the poles broke in gusts above 55 knots without protection; unless the
tent was collapsed, the torn outer tent then flogged itself to pleces. Three of the four poles could be fitted double and this became our standard routine. Later we also fitted storm guys at the 4 pole crossover points. Together these two modifications increased the blow out windspeed to 80 knots when unprotected: still not enoughe (Wintergear incorporated storm guys and fittings for double poles in the Mountalin Tents: the Second
summer team found these better, and also found that doubled II ght duty poles were less prone to breakage on erection).

In the first summer and early winter we tried to find snowfilled crevasses to up the snow to form walls all around. Although this system protected the tents from wind, they drifted up badiy, and were more prone to bur lal. In wintor the top of our tento we needed a tunnel to gat out, and we lived like rabbits untll the weather al lowed us to dig out. Although the Super Novas stood up to bur ial extremely well, keoping an airway open foet of snow fell, and the spindrift was worse. We had a rethink, and decided digging in was not the best method.

Our adopted system for pitching camp was to site the tents individually, spaced across the prevailing wind and to bulld a protective wall of sawn snowblocks for each tent form a windscoop outside the wall, and ramping up the outside of the wall to protect it from erosion. It became routine to build these every time we pitched. If the weather was
fair, one person started to put up the tent while the other built the wall. If we had to
pitch in a blow, we both built the back fall first, then erected the tent in its lee. It generally took us 2 hours to complete
every minute for the security we earnt.

With the tent reasonably secure, we would put our $\mathrm{kit}$ inside. This was normally
imats, a sleeping bag inside our bivouac bag, a itent stuffsack" of personal gear cooking stove, nester pots, mug and spoon. We took it in turns to be the first man in. The inside man had the important job of getting that first wonderful brew on. Meanwhile with snow (for water), and finlshing off the snowwall etco. The pulks had to be secrech and marked with bamboo canes. Some of us chose to dig a hole in the (downwind) entrance porch. This made it easler to get in, and formed a bench where we could sit and brush off
snow before entering the inner tent. The extended perch of the Super Nov a weather lock; we could get in and close the outer zip before opening the inner tent. With a 2-man tent we could afford the luxury of having our packs in the porch, which

side, the Inside, the layout was normally the same in all tents, with Karrimats on each remaining central space. Boots and snowbrush were usually in the fropts porch up the peebotitles and small snowshovel, but in 2 -man tents they could be put with other personal
gear in the segments outside the Karrimats.

We took turns to cook (spoll, burn, spili) our foodo If it had been a long day,
it was meal, then sleep. When we stopped with time to spare (normally due to weather), we had time for diarles, reading, and a game of chess or scrabble. starts (any time between 0100 and 0600 ). We melted water the night before: it al asually
froze, but a pan of ice will melt more quickly and easily than very cold snow. Caution was needed with our metal utensils, as they would stick to ungloved fingers in cold breakfast (porridge) arrived together. Drinking became a chore in the The first brew and to have 3 pints to combat dehydration. However this was not always possible, as internal pressure buil up and tripped the panic switch, and desperation gave us manic strength (iscozer outs ide either if snow in our longjohns that way. Breaking camp normally took 3 hours from the cook waking to moving off: we seldom
managed it in less than 2 hours, and it usually took even longer after heavy drifting. managed it in less than 2 hours, and it usually took even longer after heavy drifting.
In very cold weather, separating the pole sections was time consuming. they froze together
requiring us to cup the joints in our gloves and rub fast until the friction heat freed
themo Application of grease eased this problemo Snowholes were used on several occasions in emergencies after tents had been
lost down crevasses, or blown out, or crushed by snow. Inside a snowhole you can feel the candle sometimes used them in preference to tents if took us about 4 hours towholes, and we if rather colder, than a got wet digging. However once established a snowhole was drier, Igloos were also used occasionally in preference to tents when conditions were

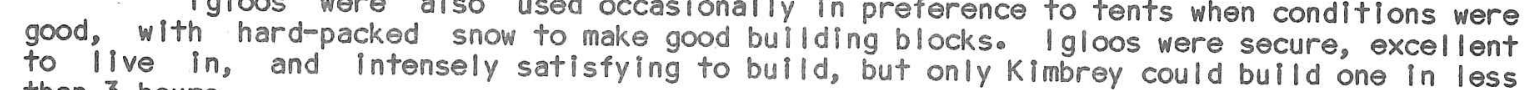

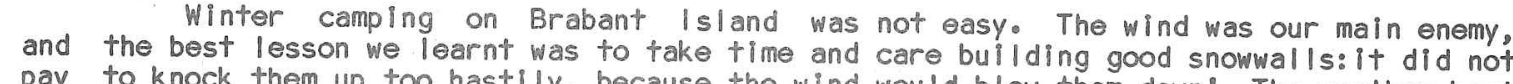
pay to knock them up too hastlly, because the wind would blow them down! The weather kep answer was to put boots on, go outside and make sur'e. Occasional rain occurred even in winter, but then it was mainly a problem of
people getting wet, not of tents falling down. (In fact freezing rain sometimes helped
by casehardening the nof by casehardening the outer tents). However in summer the melting snow surface caused
problems. The surrounding snow would melt away, leaving the tents perched on $3-4 \mathrm{ft}$ pedestals: a lot of work was needed to keep the valences firmly weightede and snowwalls simply vanishedo. When the bare glacier ice was exposed this work sometimes required
crampons one Snowholes were difficult to make then and wet to live in. However conditions up in the hills were usually still cold enough; on the coasts we could usually find a
sheltered patch of moraine to camp on, and snowfilled crevasses came into their own again
for tents or snowholes. Over the whole 15 months quite a few mobile tents were wrecked by wind or
snowslips (and one was burnt?; several were temporarlly lost down crevasses, and some permanently lost in burled caches. However we never relled solely on our tents: snowsam and snowshovels were always carried separately, and we had trained to use snowholes as
our ultimate fallback. We confirmed that wintering in tents is safe and practical, and that work and
travel are possible in such conditions. We hope that this demonstration will open the door for other well-prepared small expeditions to winter in the Peninsula reglon. Nevertheless we consider that a small hut at some convenlent basecamp site is essential, as a group For a small expedition the ideal construction for such a hit would be of strong stores 
The skidoos were originally our insurance against HMS Endurance being unable to land us on Brabant I slando In that case our opptimistic plan was to be landed at Palmer
Base and use the skids to ferry our suppliles overland, then into boats across to Brabanto Three skidoos were purchased, a new Alpine 503 (sponsored by Saccone \& Speed) and two ex-Transglobe Alpine 640 's. The 640 s were serviced by MVEE Chertsey, who also
incorporated varlous modifications suggested by BAS and by 0 liver Shepard of the Transglobe teamo. Alpines are workhorse machines with two drive tracks and one steering sk? In the event Endurance was able to land us on Brabant I sland. However after
a month on the island we decided that the skids would be useful there, as unexpected
pledmont glaclers seemed to offer reasonable routes. Endurance transported the three lds from Palmer Base to Metchnikoff Point.

Driving skids is easy in good conditionso. Operating them on Brabant I sland
was not easy, and we had a lot to learno. All our skids carried spares and tools under the was not easy, and we had a lot to learno. All our skids carried spares and tools under the
seat. Spottiswood modified cowlings to carry ice axes and marker wands. The most
Important tool carried was the shovel.

is very dificant is so crevassed that the skids had to travel roped together. This to tangle into skis and track. Stuttard allieviated this problem by fitting elastic shock

Snow conditions decided when we could travel. I ce or (worse) loose snow caused traction problems. There was little we could do about lcy conditions except crampons to the tracks). we had established a track. Traverses caused problems. The skids tended to fall of downhil or roll over. Once one skid had gone off it would pull the other two off as more digginge Often we would dig a track along the traverse line before attempting it,
this worked well.

Sledges were a blg problem. The ex-Transglobe steel sledges we had bought for
hauling heavy loads across the gentle Marr Ice Pledmont for Brabant's mountains. Sometimes the skids could not pull the empty sledges! heav one skid was over loaded the big problem was trying to coordinate power from two or three Each skid has a load area behind the seat. This wer used for ferry runs on stown load. when a loaded sledge could not be pulled. For most of the winter we used our pulk although, these were not really strong enough and tended to capsize due to their narro These proved to be the answer, attached close cutting down one side and opening them out. could carry large loads (eg 16 full jerry cans or a full 45 gallon fuel drum).

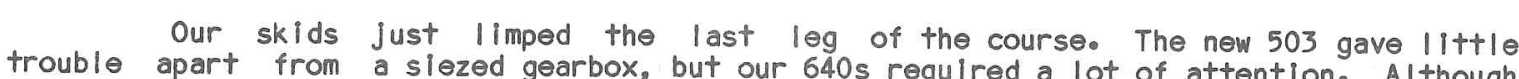
we had a good spares backup we were still caught short. This meant repairing parts whic really needed replacement (eg sheared drive axle). The amount of spares carr led depended
on the trip and distance from base. Methanol proved invaluable in winter for de-icing
carbs, magnitos etc. We made it practice to put a squirt in the

Skidoo driving was shunned by some (in favour of manhauling pulksl). It was never eablems of mountalnous operation in winter we learnt a never afford to rel ax. Despite left by skidoos made travel quicker, easier and safer. A full report will be made avallable
to the

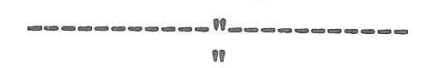

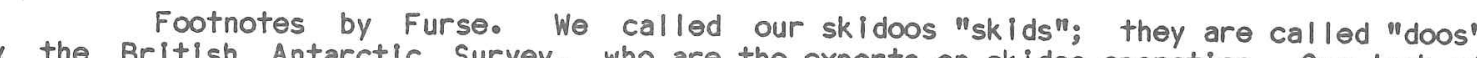
previous experlence was a severe handicap, but by sheer chance spottiswood (a rally driver) above has typically understated the mechanical problems they overcame with our oos of The skidoo team operated in more mountainous terrain than usually traversed by crevassed areas unl ike most Arctic users. Operation in winter proved particularly difficult because of the heavy snowfall and severe drifting, not to mention the coldo. The bunge tow
rope and the fuel drum sledges are two very useful innovations by a team of skidoo cowboys
who performed superbly through the long winter.

"Manhauling is neither glorious nor heroic, but unpleasant, Sweaty, toll Isome and stup id".
Roald Amundsen (menter Roald Amundsen (member of Adrien de Gerlache's Belgica
Expedition, 1898 , after their discovery of Brabant Island,
and the first Antarctic sledging there. "Merde, these crazy British and their ********.* pulking".
Francois de Gerlache (member of the Joint Services Expedition
to Brabant Island 1984) after his first sledging journey there.

Naively extrapolating from Elephant Island experience, I had anticipated Journeys on skis - backpacking up to 6 days ratlons between and from widespread dumps and caches.
Luckily 0ak ley purchased ten $6 \mathrm{ft}$ Redningspulkar from a Swedish manufacturer, Solatun Sport. They were flat-bottomed wooden pulks with 4 plastic runners, low sides, and fabric covers
secured by hooks and elastlco The harnesses were of flexible II diao bamboo. Such flat-
bottomed bottomed pulks tend to plough into soft snow more than boat-shaped pulks, but are more
stable on traverses. This report covers operation rather than construction, but we should Poport covers operatic
the solatun pulks.

In practice, travel on Brabant Island absolutely required more rations and fuel
than could be backpacked, due to the long distances, difficult terrain, short winter dars. weather holdups, and for all major overland journeys. Pulks were taken to $8000 \mathrm{ft}$ during the ascent of used Parry, and were used for totally self-supporting exploratory journeys of $2-5$ weeks in all
seasons. Pulk loads up to 180 lbs were used manhaul ing; dally dlstances of up to $23 \mathrm{~km}$ were achleved and slopes up to 50 degrees were surmounted by relaying. Pulks were also towed
benhind skidoos with loads of up to 300 lbs, (6 full Jerrycans), inevitably getting quite a
battering.

so we very few team members had used pulks before, and those only 2-man or 3-man pulks; been flown into "Dayglo" and those at Metchnikoff Polnt were initially used as 3 -man pulks. the rear loops were moved to the midlength to improve traversing) hauling and braking (late Atkins and de silva developed reasonable 3 -man pulking techniques on an 18 day journey to
Pare Glacler: they rotated horse/leader/brakeman dally, the horse clipping the shafts direct to his rucksack waistbelt by Karabiners. Leader and brakeman hauled using a prussik fro thor refonements these technques were used thereatter for 2,3 \& 4-man pulk partles avay in one pulk, Inefficient haulage effort, difficult coordination, awkward relay loads, and Three-man pulks often involved fairly short rope traces, with all 3 men clipped
to the pulk. In Aprll. Evans' crevasse fall as horse (\& de Gerlache's narrow excape as
brakeman) forcefully demonstrated crove brakeman) forcefully demonstrated the dangers of the systemo Thereafer I-man pulking as
our constant aimo However 3 pulks were then in use with the skidoos, leaving only 3 ; so
realisatlon of that alm was delayed.

In August, Atkins, Beattie, Evans \& Lumsden used 3 pulks on their 17 day winter reconnaissance to double as a rope brake and the bamboo harness was lashed to prevent its sliding sideways the pulk when over-running. Light clips were also fitted in a partially successful attemp t that the rope held the man rather than the pulk). By then most horses were use in a fall (so and foot jumars/prussiks as their personal protection on the climbing rope, tieing the end cast off to hang on the rope end, with the pulk hanging from the rucksack could simply be free to jumar up the rope. in crevassed areas all four men were llinked on three 450 cllmbing ropes, but on safe areas it was easier and quicker to travel in two separate roped
pairs.

8000 ft In October seven pulks were used extensively to minimise portering journeys to on the traversing worked out for use stralght up steep slopes, but were not in fact required 


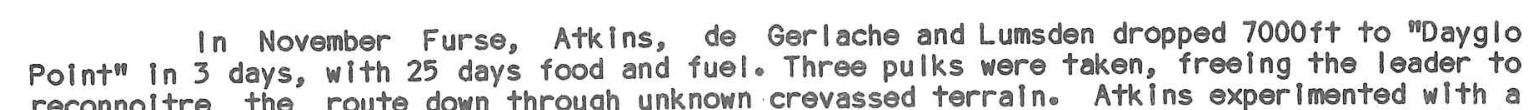
reconnoitre the route down through unknown crevassed terrain.
sling operated by the horse, to apply and remove his rope brake.

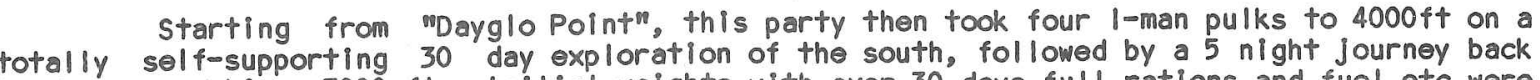
to base reaching 7000 fto Initial weights with over 30 days full rations and fuel etc were packs of about 40 lbs and toal pulks of $401 \mathrm{bs}$ plus some rock specimens. This was the culminating pulk trip of the winter phase and the longest of the expedition. It amply demonstrated the advantages and potential of l-man pulkingo Journeys
to exploit the best snow conditions which proved very worthwhile in summer.

Instrumented tests by a Norweglan physiologist had shown that least energy was expended if all the load was on the pulk, showed that in soft snow and/or on steeper slopes, it is better to carry a good comfortable load in your pack. (Calculations for a total load of $80 \mathrm{lb}$ confirmed this observation, and are available). Using daysacks as rations-sacks simpliffed changing the pack/pulk
to sult conditions: more importantly it greatly simpliffied relaying up steep slopes.

Atkins has completed sketch designs for a light, robust 2 -man ridge tent incorporated in one pulk, which can be very quickly and simply erected
pulks used by a 2-man rope teame He plans to make a prototype for trlal.

Manhauling sledges is usually labor lous and often exhausting. However it
enables one man to transport 200 lbs of gear at a time, Instead of needing $3-4$ relays backpacking. Pulk sledging with I pulk per man is strongly recommended for small partles requiring to be solf-supporting for Jour in Flat polar terrain, such pulk parttes wald be able to load up for 7 weeks, or even more. For small expeditions without the resources to
caches, the potential of 1 -man pulk sledges is tremendous.
One of the aims of the expedition was to make first ascents of Mt Parry and all other major peaks on Brabant I sland. The team's mountalneering experlence was limi ted,
in fact almost half the team were novices, so it was essentlal to have pre-expedition meet

Brabant Island was one of the largest virtually unexplored islands left. The conjunction with the original aerlal photographs taken in 1955/56. The lack of detall on the map was one of the restrictions to movement around the island, in addition to objective dangers such as crevo chose SIIva T15 Compesses and Thommen altimeters, and thelr combined use was Invaluable for movement in cloud.

The nature of the terrain, deep snow with a lot of ascents and descents, made sk I mountaineering skis with skins the best mode of travel. We used Dynastar Yeti skis with Emery Altitude Plus bindings and found them excellento Equipment was carried (or dragged ice hammer, deadman two icescrems, pair of Clog or Jumar ascendeurs or prusciks axe slings etc. ROD Thatcham had provided a selection of iceaxes varying from the Stubal Manaslu to the older Mcl nnes Massey: a long axe of $85 \mathrm{~cm}$ was found more sultable in this but several members would have preferred an ice hammer with longer shaft and pick such as a Curver ice harmer. Clog screwgate and snaplink Karabiners were used throughout: application of WD40 prevented the Karabiner from freezing up in low temperatures.

and were worn by those who could get used to wooden stl had been bought by the expedition Experes and modified their Dolomites, the drawback being that the leather froze overnight unless placed in one's sleeping bag and they were cold to wear. We used Lowes Footfang crampons, which
are simple, easy to fit and warmer: they also proved very durable, but note that the
snowteeth at the front are essential. The team always travelled roped up, using $9 \mathrm{~mm}$ Edelrid Everdri Kernmantel rope,
which proved durable. The ropes were in $45 \mathrm{~m}$ lengths, usually with two to a rope. Sking
with heavy packs and a pulk was tedious and often frustratingo Occasionally, whilst negotiating large crevasse flelds, two ropes of two would rope together for safety. There
were two methods adopted by members for tying on. The first was to tie the rope directly were to the harness, with a sling from the rucksack to a Krab sliding on the rope between the harness and waist Jumar: If one fell into a crevasse, the rucsack was jettisoned keep ing the rope taut while one jumared up and out, pulling half the weight of the rucksack.
This was not useable with a pulk attached to the rucksack, when an alternative method was used. Thls was to to tie the rope directly to the rucsack, using the Jumars for personal protectlon: the argument agalinst this is that ascendeurs are not designed to take shock loads: however travelling on tight ropes there should be little shock loado with rucksack
jettlisoned, one jumared up the taut rope. Deadmen were most often used for belaying in winter, though icescrews were often needed in summer. Long shaft iceaxes made swift belays in crevasse falls, and lceaxe belays were often used for speed when crossing bildges. The
dynamic body belay was popular, due to the fact that frozen ropes and Sticht-plates become
unworkable. Direct belay systems were also used (usually with an italian Hitch), while an unworkable. Direct belay systems were also used (usually with an I tal fan Hitch), whil
Alpine clutch was used for hauling, either by direct pull or a 2 to I pulley systeme

Travel was a slow hard sloge Weather and snow conditions were main factors
af fecting speed of travel. Short day longth in winter, high winds, blizards foid and fuel af fecting speed of travel. Short day length in winter, high winds, blizzards, food and fuel contrlbuted their fair share of holdups as negotiating crevasses, icefalls, \& bergschrunds al took time. Most team members experienced falling into a crevasse, usually held on a
tight rope but with 9 or 10 "headunder" falls. However everyone had escaped unhurt until Waghorn's accident in the last month. Quite often the edges were overhanging, which caused problems for the person Jumaring out, and for hauling kit out Avalanches were a threat throughout the year, in winter due to large snow build
up, and in summer due to the warmtho Each team member had a P i eps 11 transmitter/receiver:
however we had a $60 \%$ fallure rate with theme Snow conditlons continually changed however wo had a $60 \%$ fallure rate with themo snow conditlons continually changed combined with high winds turned into raging blizzards lasting days Pulking in this and powder snow was soul destroying. In spring and summer with warm sunny days the snow
surface deterlorated so much that it was worthwhile travelling during the night or early

As expected, most of the volcanic and conglomerate rocks were frost shattered and dangerously unstable, or swept by hanging glaclers, although good granite sea cliffs in midwinter in crampons: this $80 \mathrm{ft}$ of glazed granite (graded VS) was the only noteworthy 
Altogether the First Ascents of 55 peaks were made, including 39 over $3000 \mathrm{ft}$.
In the first year (except for the 2 day ascent of Mount Hunter) every ascent involved self supporting pulk trips of over 2 weeks, although it was often possible to climb severa

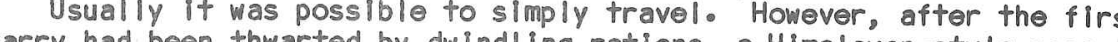
was used for the successful ascent in october, portering for 2 weoks of relatively good

Many ascents were stralghtforward ski-plods (eg Roentgen Peak \& "Freud Heights"),
Others were simple Grade I climbs (eg Mount I mhotep) or of simllar tochnical standard but requiring route- finding through mushrooms (eg "Mount Frederick Cook"). The northern hills season) was a fine ridge. The southern peaks were nore varied The most technicel cling on in the first year was Atkins and Lumsden's ascent of Celsus Peak, with much exposure, and molst winds rising up windward slopast: thy unhurt the only serlous open air fall of the expedition. Second Summer climbs on Mt.Bulved in Brabant's new Chamonix were assessed as up to Grade 11 . One of the most satisfying A handful of worthwhile peaks remain uncl limbede. Attempts to climb Mount Morgagn
in the First Summer and Winter phases were each baulked (after long approach journeys) In the First Sunnmer and Winter phases were each baulked (after long approach journeys)
by degp fresh snow creating unacceptable avalanche risk on the steop ramp which was the only feasible approach \& in the Second Surmer Waghorn's injury occurred in the early stages of the approach. Hales Peak on the northeast ridge of Morgagni also remains uncl imbed. appeared to be slightly higher from the northern summit). The the southern summit (which inger also remains untouchede. Mount Erhlich and some other minor peaks in the south were the atempted, due to the early re-embarkation. The remaining jewel of Brabant I sland is

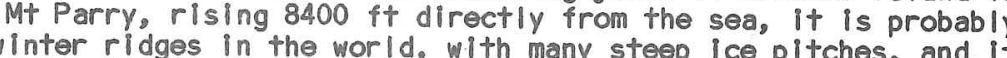
would be worth a small mountaineering expedition in itself.

The 29 First Ascents 11 sted below are just a widespread selectione Space
precluded the 26 others ranging from 1150 - $8050 \mathrm{ft}$. Many of those were Just as memorable,
as were the Journeys to reach themo

15 Jan 84. Mount Hunter
2 Feb 84. "Noddies Hat"

4 Feb 84. Virchow Hill

5 Mar 84. "Peor Arduan

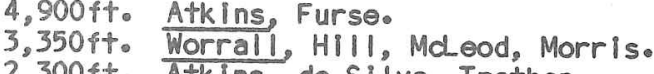

4 Apr 84. Roentgen Peak

26 Jun 84. "Kelso Top"

5 Nov 84. Einthoven Peak
10 Nov 84. "Amphitheatre Ridge"

13 Nov 84. "B lack Sheop Top"

23 Nov 84." "FF ather Peak"

Nov 84. Mount Imhotep
Dece Summit"

Dec 84. Galen Peak

Dec 84. "Mount Freder Ick Cook"
Dec 84. "Ben Bangers \& Mash"

19 Jan 85. "Minot Peak"

22 Jan 85. "Mount Cherry"
2 Feb 85. "Mount Lynwen"
2 Feb 85. Victorla Peak

3 Feb 85. Hunt Is I and
16 Feb 85. "mpogasus Peak

27 Fob 85. "Chleftalin"
9 Mar 85. "Little Sister"

2,300fto Atkins de silva, Trathene

5,700 ft Hankinson, Trathen.

$\frac{\text { Hank inson, Atk Ins. }}{\text { Trathen, Atk ins, Corbett, Furse; }}$

2,360ft. Stuttard, Beattle, Corbett, Evans,

3,330ft. Beattle, Evans, Lumsden, Stuttardo

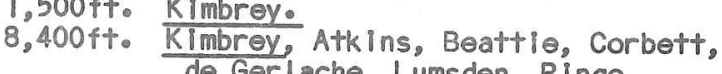

2,660ft. Beattle, Kimbrey, Ringeo
$4,700 \mathrm{ft}$. Binge, Beattle, KImbrey.

4,400ft. Furse, de Ger lache.

4,300 fto Atkins, Furse, de Gerlache, Lumsden

5,270tt. Lumsden Aache, Atkins, Furse, Lumsden.

$300 \mathrm{ft}$ Lumsden, Atkins, Furse, de Gerlache.

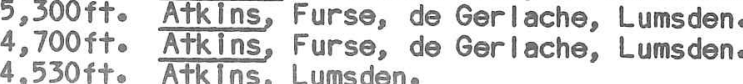

1,500fto Clements, Hall.

3,060 ft. Taylor Ball Lawrenceo
1,600 ft. Hall Allen, FlInt, Moffat, Waghorn,

1,570ft. Clements, G111, Hall.

3,300 f. Ringe Lawrence.

$3,430 \mathrm{ft}$ Allen, Lawrence, Taylor.
$3,500 \mathrm{ft}$. Taylor, Al len, Lawrence.

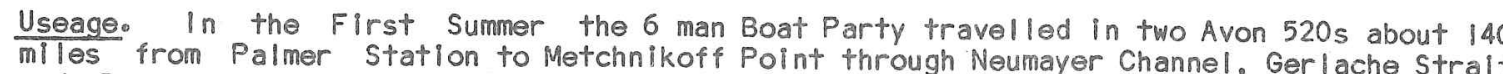
and Bouquet Bay. After that the boats were used only locally from Metchnikoff Point. The
boats spent the winter above the beach at Metchnikoff Point, until Kimbrey set them to work

The Second Summer Boat Party brought a Lifeguard 510 and used this and one or
other of the Avons intensively for most of January and February 85 , for rapid movent the other of the Avons intensively for most of January and February 85 , for rapid movement to
and from interesting coastal sites and as safety boats for canoeng. Including the circumnavigation of the island (about 100 miles), about 490 miles were covered in pairs,
plus another 100 by single boats - a total of about 1080 boat miles. Conditionso In the First Summer and Winter most operation was in calm stable weather,
though some $8 \mathrm{ft}$ swell and dense brash was encountered in January 84.

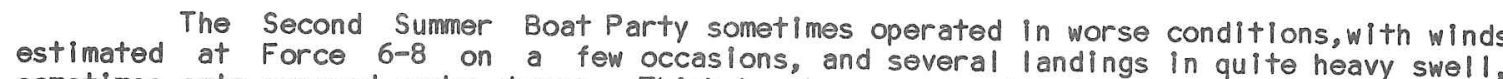
somet mes onto exposed rocky shores. Thick brash was encountered on several occasions.

Sea temperatures were usually between freezing and I degree below. Although air
temperatures were seldom more than 5 degrees below freezing, wind chill effective

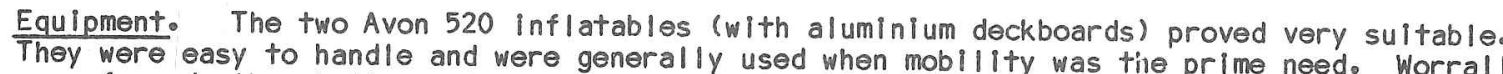
re-enforced the bottoms to strengthen them, and they proved quilte durable, suffering no bottom tears and one overwinter, nor hitthe accurred. Their 2500 lb payload (incluom engines and crew) was less than the Lifeguarc, but on the whole they wero these conditions, because they were lighter and easlor to haul out above storm beach
level.

The one Llifeguard 510 was more robust, and carried a heavier payloade. Although slightly slower and a handicap, making it more difflcult to haul the boat up to safety
slze were however a
overnight, although this was partly a function of the different engines fitted rellable in the five long-stalk OMC 35 HP outboard motors ( 1981 models) proved totally without use in winter, most of the time buried in snowdrifts. Two of them were swamped for several hours when a moored boat capsized overnight: Hall dralned them, drowned them In February 85 several transmission fallures occurredo Two sheared drive shafts were attributed to repeatedly striking brash ice beforehand. Three gearboxes jammed toward the being fllled with the low-viscosity oll intended for low temperature use in wintarently managed to successfully cannibalise other engines to keep two units going Despite these later defects, these engines were preferred because of their lighter weight, which made
it possible (though not easy) to manhandle them up over stranded brash and rocks to above
the reach of waves. defects. However the 4 HP Mariner outboard motors proved very durable and suffered no serious the tendency was to moor the boat rather than haul it out - this led to the caps that Minot point, when one engine was lost as the boat was pounded on the rocks. However Hall
and Waghorn stripped and drained the other swamped engine, which ran well thereafter.

All the propellers were fitted with built-in shock absorbing couplings which
proved invaluable as brash ice was struck on many occaslons. Battered and broken blades on brash but some when landing loads on rocks in sumell. (Propeller guards were not fitted,
as these tend to collect and hold footballesized humps of brash).

gear allowing Mariners in the Lifeguard were supplied by E.P.Barrus with twin operating January 85 , however thereafter the boats were operated on one engine for economy and in avoid having both damaged simultaneously by striking brash or rocks, so the twin facility
was not used.

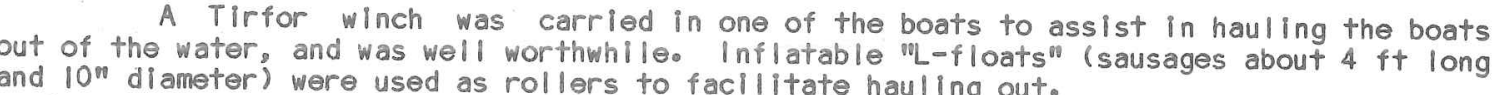




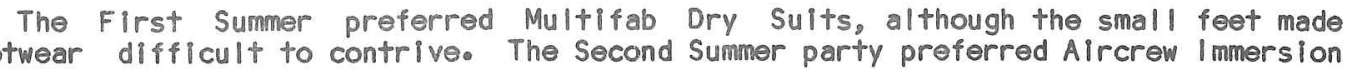
warm footwear difficult to contriveo The Second Summer party preferred Aircrew Immersion used. Climbing into, and out of, cold clammy outer clothing was made 11 ght of o Boot
repair kits including oyster clamps proved good, although most of the Bostik 2402 had been used for tent repairs during the winter.

One pint of Duckhams two-stroke oll was used in each 5 gallon fuel tank, giving mixtures of $40: 1$ or richer. This proved satisfactory. 4-star gasoline was used because
the skidoo engines required leaded fuel. A 45 gallon drum with the top cut out was an

Maintenance \& Repairso Tender loving care (by Worrall and Hall in particular) produced
remarkably good avallabillity. During the second summer Hall successfully undertook semaral goo several quite major strips after engines had been swamped, and to change damaged gearboxes
and driveshafts etc. These were quilckly and successfully achieved, despite lack of socket
spanners and impact screwdrivers cached with the skidoos.

Operation \& Performance. Whenever possible the boats were operated in a pair for safety. which was of the two fitted engines this gave a very good margin of safety for fallures very quickly of the glaciers. (On one occasion 5 team members in two boats had an 8 mil les tow to the nearest landing site, with one serviceable engine out of four). During the last
two weeks on the west coast it was necessary to use one boat alone on several occasions.

Operating on one englne at the lowest stable planing speed lor dogging along at 5-6 knots) proved very economical on fuel. Fuel consumption characteristics were
calculated for the Avons, and checked during training: these figures (which proved rather

Crews varled from one to three. Two in each boat was the ideal for carriage of
ads, but up to 6 were carried with full survival gear and rations for overland heavy loads, but up to
travel, plus adequate fuel.

The longest total travel in one day was about 50 milese In the Second Summer the power boats proved conclusively that doy was athe 50 nilos. Point to Claude Point was a dramatic contrast to the overland jeurney time which averaged 6 days, once took 28 days in winter, and was later shown to be fairly dangerous.

The bats were seaworthy enough and there were few days when they could not put
to sea. Landings were the maln 11 mitation, with only one tiny beach found between Hunt island and Cape Roux. On the west coast the heavy swell could deposit a boat high and dry on a rock complete with the engine running, white the coxswain waited for the next wave Apart from visiting isolated beach sites to count seals and breeding birds, the
boats provided good platforms for whale-watching. They were in turn closely observed by party operated successfully for an extended period in often atrocious conditions, in total isolation. boats' capabillities to the full to explore around the whole island, and to put scientific partles ashore at sites inaccessible overlando. They certainly achleved much more than I had bellos swamping that they made light of. With little previous experlence, Hall proved an outstanding natural coxswain: now he would like to shoot the colorado in either of the two boat/engine combinations used on Brabant I lando I do not know of any po
boats to compare with the second Sumner Party's since Shackleton's time.
GENERAL. Although one of the expedition aims was to carry out a circumnavigation of the island, the principal purpose of taking canoes to an apparently hostlle part of the world
was to provide an alternative method of tranport, in particular for landings around the island. In the event, a complete circumnavigation of the island was achieved by boat and The circumnavigation by inflatable and by canoe became a scientific

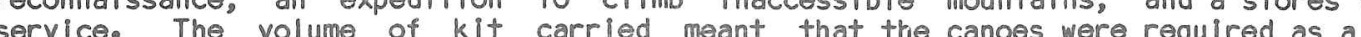
transport to supplement the boats. They were also used as local transport to visit outlying islands \& stacks etc to carry out scientific work.
The problems anticipated for canoeing in the Antarctic were bad weather,

temperature of the water, lack of landing-sites, and the general hostillity of the climate
and terrainos stated above, the canoes circumnavigated the island successfully in the (greater than expected) perlods of good weather. Air temperature was more critical than any landing sites, particularly on the North East side of the islando During the circumnavigation the canoes were used for local excursions when the boats were ol ther not EQUIPMENT.

Having decided to take canoes and specialist canoeists to a hostile part
of Canoes.
the world, the choice of canoe was limited to single sea kayaks, and the world's best canoes for that purpose are Valley Canoe Products Nordkapp Kayaks. We took Nordkapps, Goodmane. Four such canoes were bought, modifled to take rafting brackets to permit stable rafting of pairs of canoes. but strongo they were extremely easy and untaxing to use

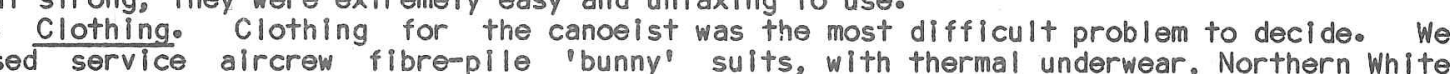
later centre sea cagoules, and goretex overtrousers. Apart from problems keeping the good weather encountered it is possible that kit was satisfactory, even too warm in the satisfactory paddling, and provided better protection had any paddler capsized and swum. good, provided the water was not washing through the mitts continuously. which hese were occasionally when paddling into a force 4-5 wind in a confused sea. One paddler, for whom the Splashsport mitts were too small, used Suzy mitts, which were lined with a silver D. Equipment carriedo Each canoe pair carried normal camping and personal equipment, and three days emergency rations. Despite the extra volume of clothes to cope with potentially Dry Sacks; other kit was protected by the excellent VCP Aquasecks or BDM climbing kit, ice axes, boots etce were carried in the inflatables, usually protected

E. Each canoeist carried the following safery equipment:Miniflareo
Spare paddles. Day/night flare.
Safety/rescue line

The pocket LOCAT beacons, when activated, transmitted on approximately $121 \mathrm{MHZ}$ and were intended to provide a homing signal for a direction finding receiver carried in the Lifeguard inflatable. (They could also be picked up by satellite). These were not used,
although one was found switched on accidently when the mechan ism to prevent such an occurrence (a plece of plastic) broke: fortunately any transmissions made were not received! The Miniflares were used sometimes to indicate position to others, but were
never seen, so white parachute flares were finally carried insteat

TEAM SELECTION

coupled with anoeists were selected on the basis of having a varled canoeing background, coupled with a varlety of rough water experlence. Previous sea canoeling experience was

TRAINING

sultable locations for canoelng consisted of a serles of separate weekend meetings at culminated in the Blue Peter fllming at Dover. A great deal of emphas is was put on races was excellent value. At Dundonnell a four day passage from Loch Broom to Kyle Rea 
Photographic preparations began slowly because the RAF photographer originally as well as cine. Equipment and film was gathered at the Fleet Photographic Unit, where it was tested and proven prlor to packing. Some generous equipment sponsorship and good
advice enabled corbett to leave Britaln well equipped and prepared for a challenging
assignment.

Photographic coverage was required for the following outputs:

1. Services PR.

3. Expedition book illustrations.
4. Presentations \& lectures.

. Advertising material for sponsors and manufacturers.

7. Expedition Report illustrations.

9. Photographic exhibitions.

Brabant Island's photographic sectlon was set up amongst the penguins at
Metchnikoff Point. A thousand miles south of the nearest camera dealer, Corbett had to

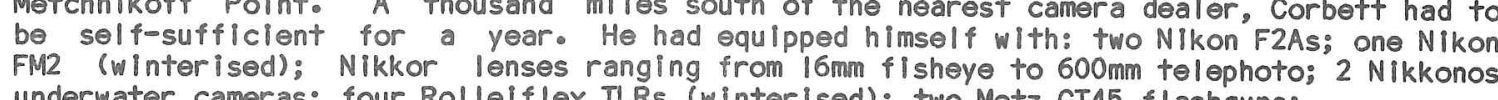
underwater cameras; four Rollelf lex TLRS (Winter ised); two Metz CT45 fl ashguns;
Western $V$ and Lunasix Lightmeters, a Benbo Tripod and a range of accessorles.

processing was undertaken, due to the conditions). The rest of the team members had the use of four Pentax SP 1000 cameras ( 3 Winter ised), $35 \mathrm{~mm}$ to $300 \mathrm{~mm}$ Super Takumar Lenses plus phortographic equipment wass powered by Duracell alkal ine batterles. All equipment had been

bottles" At basecamp the photographer worked from 10 plycases and watertight "Schmoolly basecamp, plus other coastal areas. During the midwinter months corbett concentrated on avallable around basecarmp. In the mountains equipment was severely restricted, to the amount that could be
carried in a full rucksack or on a heavy pulk, but the skidoos helped considerably. Boating
skidooing, pulk-sledging o ski-mountaineering offered fabulous subjects, with spectocular skidooing, pulk-s ledging \& ski-mountaineer ing offered fabulous subjects, with spectacula
backdrops. There was rarely a moment when Corbett was without a camera around his neck.

$-5 \mathrm{c}$. This Temperatures ranged from $+15 \mathrm{c}$ to about $-30 \mathrm{c}$ with monthly means between $+2 \mathrm{c}$ and $f 11 \mathrm{~m}$. However winds often exceeded Gale Force, producing windchill equivalent temperatures

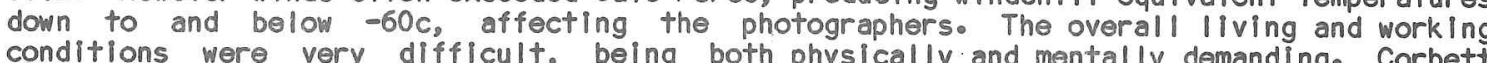
began to lose feelling in all his fingers, and went down with mild frostbite in May. Care of equipment and film in these conditions required strong discipline and constant determination, and being unable to soe any results for a wholo year was a hard strain.

and in thendensation was a continual major problem in all seasons, but worst in winter Cameras frequently took severe knocks and we could never be sure that $k$ it was functioning

Summer. Hack in Britaln, Hall (and later Barker) were buslly preparing for the Second photographs. Their equipment provisionlng was severely handicapped by Corbeft's detalled feedback message going astray in the Falklandso Further Service equipment was not avail able and, constrained by a tight budget, they underestimated the attrition rate on

At the end of December 1984 Hall and Barker arrived to find themselves short of

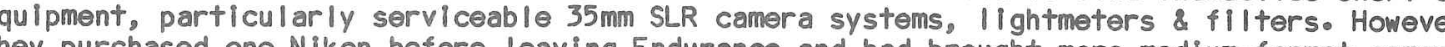
systems: two Winterised Hasselblads (on free loan from Pelling \& Cross), one CM500 wIth $80 \mathrm{~mm}$ and $150 \mathrm{~mm}$ lenses and one Superwide $38 \mathrm{~mm}$ fl 1 xed lens camera, plus three FuJ Ica HDS $35 \mathrm{~mm}$ The Second Summer boatwork was extremely arduous for photographic equipment, with
a lot of salt spray and several swampings on landing one of which put paid to Hallis two
Nikon cameras, the $150 \mathrm{~mm}$ Hasselblad lens and his only lightmeter. However Barker generously gave Hall his only lightmeter when the two partles met, and both kept their diminishing bombroof storage containers proved to be the Bowater International resealable plastic

\begin{tabular}{|c|c|c|c|c|c|}
\hline & \multicolumn{3}{|c|}{ Number of Rolls } & \multirow{2}{*}{ Types of Fllm $(+A S A)$} \\
\hline & & & ow & 25 & \\
\hline \multirow{3}{*}{$35 \mathrm{~mm}$} & Colour Transparency & 80 & 160 & 270 & $\begin{array}{l}\text { Ektachrome }(64+200), \text { Kodachrome }(25+64) \\
\text { Fuj ichrome }(50+100), 3 M\end{array}$ \\
\hline & Colour Negative & 0 & 0 & 0 & \\
\hline & Black \& White & 85 & 139 & 35 & FP4 $(100), \operatorname{Pan} F(50)$, HP5 $(400)$ \\
\hline \multirow{3}{*}{$6 \mathrm{~cm}$} & Black \& White & 0 & 42 & 77 & FP4 $(125)$, Pan F (50), HP5 (400) \\
\hline & Colour Negative & 0 & 53 & 0 & Vericolor $(100)$ \\
\hline & Colour Transparency & 0 & 0 & 48 & Ektachrome (64) \\
\hline
\end{tabular}

Late in 1983 Hall had made an excellent agreement with Colour Processing

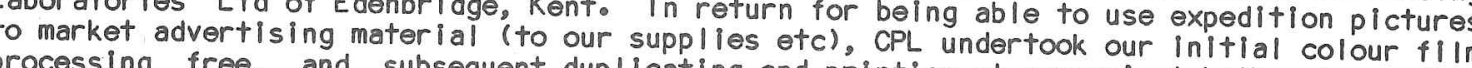
gave us the highest qual ity processing: a number of beautiful enlargments (up to $7 \mathrm{ft} \times 4 \mathrm{ft}$ )
have been produced up to the time of writing. d up to the time of writing.

All black and white and colour negatives are held by Corbett and Hall. Sets of
contact prints of all black-and-white, and colour-negative films are held by Corbett and urse, and by Hall \& Waghorn for their respective parties. $35 \mathrm{~mm}$ colour transparencleses have to the individuals who took them (and thence distributed among team members) returned originals of this "Expedition Set" and of al! $120 \mathrm{~mm}$ colour transparencles are currentiy

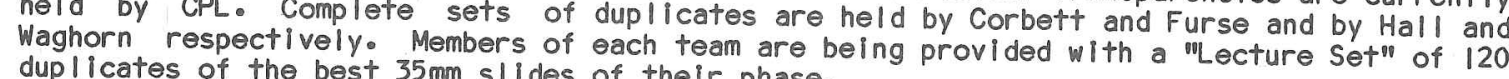

Hall arranged with Tophams Picture Library, of Edenbridge, Kent to lodge selection of the expeditions best photographs with themo These will be commerclally
avaliable from late 1985, after initial useage by the expedition in magazines etco has
reduced.

Footnote by Furse: The three professional photographers, all from the Royal Navy portfollo of pictures during the expedith in producing an outstanding and comprehensive post-expedition marketing is also a distinct advantage to the expeditions. Their keen produce a detalled report covering all photographic aspects of the expedition (particulerty

Enquirles for expedition pictures may be made as follows:-

General enquirles: Commander Chris Furse RN, Hegg HIII, Smarden Kent, TN27 8NX。
Tel: 023.377.229 (or 01.244.0512)

Black \& White prints: (1S and OW) Leading Airman (P) Jed Corbett,

(2S) Fleat Photographic Unit, Tipner, Portsmouth, Hampshire. c/o 44 Gladstone Road, Farnborough, Kent.

Colour Reproductions: Mr Bill Davidson, Colour Processing Laboratorles Ltdo Speedwel I C Cose, Chandlers Ford, Eastleigh, Hampshire S05 3NB

Lbrary Material: Topham Plcture Library
(after late 1985) Edsels, Markbeech, Edenbridge, Kent. 
The aim was to produce a 50 minute fllm for TV. For this, the most interesting aspects of the expedition revolved around the survival through the whole winter. The film would concentrate on the human element, living in tents, working and travelling.
De Gerlache's participation introduced an element of historical interest: tape recording of his gradually increasing command of Engl Ish would provide a good impression of time
passingo. He, Furse and Atkins were chosen as "stars" around whom the story was meant to
evolve. Corbett's cine experience before 1982 comprised a two day course on loading a
Bell and Howell. Being tasked with shooting a film throughout an Antarctic winter, he did
more than panic. Fortunately, working in the cine Section at the Fleat Photographic Unit. more than panice Fortunately, working in the Cine Section at the Fleet Photographic Unit,
he was able to plck people's brains, and famill arise himself with the Bolex. He also he was able to pick people's brains, and famillarise himself with the Bolex. He also
recelved helpful advise from Edwin Mickleburgh and John Lane, two professionals with
relevant experience.

The Services Sound and Vision Corporation provided on loan two hand-cranked, triple-turret-lens Bolex cameras. After much consideration (largely a matter of finance) the expedition finally decided to purchase an expensive synchronised-sound system: two
Beaulifeu RI6 camera bodies; $10 \mathrm{~mm}$ and zoom Angenleux lenses; two Uher 4200 Report tape recorders; uni- and omni- directional Sennhauser mi crophones, plus a Bilora magnetic head tripod etc. The Beaulieu system would provide the bulk of quality TV material, whilst the Bolexes gave a more moblle and dependable cine-facllity down to -40C. Ring adaptors
enabled Pentax and Nikon lenses to be used on the cine-cameras. Because of the large
investment in equipment, the cinefil tm became quite a high priority expedition aime

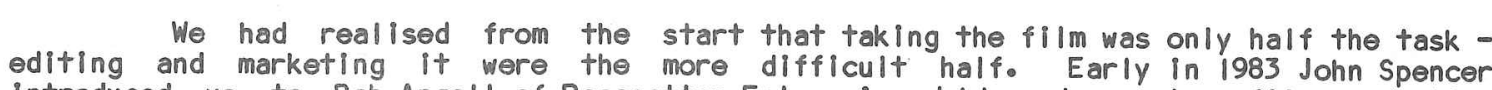
editing and marketing it, were the more difficult halfo. Early in 1983 John Spencer company. Showing keen interest as an honorary adviser, Bob gave us definite marketable
objectives, and also arranged most useful contacts. Before departure, the expeditlon made objectives, and al so arranged most useful contacts. Before departure, the expedition made
a formal agreement for Pacesetter Enterpr ises to control the editing and marketing of all our fill on a percentage basis. The importance of pre-arranging the marketing end cannot be over-emphasized: without Bob's experience (\& enthusiasm) we, would have ended up with FuJ Photo Film LTd donated $50,000 \mathrm{ft}$ of RT 500 (400 ASA tungsten). We then
purchased 15,000 it of RT 125 (100 ASA tungsten) to cater for sunlit snow conditions. These colour reversal films require very precise exposures, so late in 1983 Corbett and
Hall flew out to the Alps for a weekend for film tests in snow. 800 Agfa 7 inch sound tapes were purchased A late additional task was fllming the First Summer Party's outward journey from
Valparaiso to Palmer Station, for which Corbett used the 1500 ft of Eastman negative fillm
provided by SSVC. Ton minutes of this film were used in the I hour 1984 Rolex Award filmo

During Corbett's year on Brabant Island the filming highlights were the boat camping, during the first attempt on Mount Parry and skidooing. These were supported by general daily life and conditions working in the winter, mostly near basecamp. A flexible The Bilora tripod was used with the Beaulieus. These relied on power from a
Honda portable generator set (bought speciflcally for the clneflilm). Unfortunately the generator became defective in May, and once the batteries ran out, the Beaulleus the unusable. (This was a secret rellef to the others when hauling pulks, after experience tripode than the larger Angenleux lenses. Very $11+t+1$ e sync-sound material was taken, but wildtrack recordings were made throughout when in basecamp.

The Second Summer filming by Barker \& Hall was considered a lower prlority, climbing were the sole objectives. In the event only one Bolex remained serviceable, paramount during the seme sequences with a video system brought by Taylor. Safety was before his only lightmeter was swamped in a rough landinge. The 18 second running time
of the Bolex proved very limiting for canoeing. For a moblle expedition like this, an easy to use vidoo, or a super 8 system using relliable expendable batterles, may be advantageous

The following material was obtained during the expedition:

\begin{tabular}{|c|c|c|c|c|}
\hline & \multicolumn{3}{|c|}{ Reols } & \\
\hline & is & OW & 25 & \\
\hline RT 500 & 20 & 40 & 0 & (3 minutes per $100 \mathrm{ft}$ reel) \\
\hline RT 125 & 60 & 48 & 9 & (3 minutes per $100 \mathrm{ft}$ reel) \\
\hline Agfa Tapes & 5 & 30 & 0 & (15 minutes per 7 inch reel) \\
\hline
\end{tabular}

the high quality material. At the time of writing Pacesetter Enterprises are a great deal of Yorkshire TV. Anglia (Assignment Adventure), and BBC (World About Us), all of whom the interested in editing the material to produce a TV feature. Pacesetters and the Expedition Expedition team members will each receive a video copy of the fllm, and of good
offcut materlal, and these will be avallable for private and non-commerclal showing.

Corbett, Hall \& Barker plan to produce a detalled technical report on all aspects
of cinefilming, together with their still photographic report. Enquirles for expedition film nay be nade as fo

Edited fllm: Mr Bob Angell,

Pasetter Enterprises L+do,

d'Arblay Street,

Londone WIV. $4 A E$,

General enquirles \& private non-commerclal showings: Hegg Hill,

Kmarden, ${ }^{2} 278 \mathrm{~N}$

Kent, TN27 8NX
Telephone 023.377.229 or 01.244.9512

or

Leading Airman $(P)$ Jed Corbett,
Fleet Photographic Unit,

Tipner,
Portsmouth,
Hampshire. 
Arrangements to open a Sub Post office on Brabant $\mid s$ land were initiated with the Philatelic Bureau in Stanley in 1981. Our alm was to ralse funds for the expedition. In
1982 the High Commissloner of British Antarctic Territorles approved opening of a sub-Post Office on the island for the duration of the Expeditiono. Furse and then Allen would act

From the start we intended to use an agency in Britain to handle all printing and marketingo This proved remarkably difficulto In September 1983 an agreement was made shipped south on board HMS Endurance but few orders had been recelved by January 1984 . Ltcdrofarmer, the Flight Commander in HMS Endurance contacteed his philatellic agent, Tony
Bray. By March 1984 a new agreement had been made between the Expedition, Tony Bray and Bray. By March 1984 a new agreement had been made between the
Cotswold Covers: the expedition would recelve 50p nett per cover.

On 17 February 1984, Sir Rex Hunt, formally opened the Sub Post Office in a tent

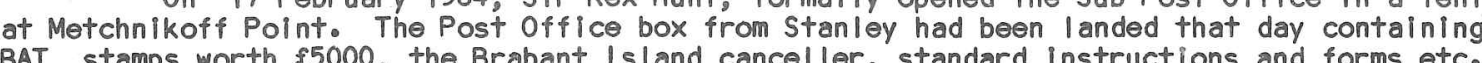
BAT stamps worth 25000, the Brabant Is land cancel ler, standard instructions and
The first letter posted was loyal greetings from the expedition to our Patron。

Routine Post Office business comprised:

a. Cancelling letters sent by philatel ists ( $\&$ registering some of these).
b. Keeping the monthly stamp Account. This took only about 2 mandays per
phase, but it unfortunately concentrated around the already hectic team phase, but it unfortuly
changeover perlods.

Stamping, cancelling and signing expedition covers was a longer process, best member got a few for private use and some were also sold, at cost, to the crew of Endurance. The great majority of the covers were serviced for sale, with a varlety of
letters, signatures on the front and additional cachets. The full series of official BAT letters, signatures on the fron
First Day Covers was as foll lows:

$\begin{array}{llll}\text { a. Opening of Sub Post Office. Manned Flight. } & \text { Cancelled } 17 \mathrm{Feb} 84 . \\ \text { b. Opening of Sub Post Office. } & \text { Explorers Definitive. Cancelled } 17 \mathrm{Feb} 84 .\end{array}$

c. First Day of Stamps Issue. Marine Life Definitive. Cancelled 14 Mar 84.

d. First Ascent of Mount Parry. Manned Flight. $\quad$ Cancelled 29 Oct 84.

$\begin{array}{lll} & \text { First Overwintering in tents. Manned Flight. } & \text { Cancelled } 29 \text { Dec 84. } \\ \text { f. First Overwintering in tents. Marine Life Definitive. Cancelled } 29 \text { Dec 84. }\end{array}$

go Team Changoover.
ho Closure of Sub Post office. Marine Life Definitive. Cancelled 29 Dec 84.
Marine Lifinitive. Cancelled 15 Mar 85. The First Summer covers ( $a$, b \& $c$ ) were quickly sold, realising a small nett
profit to the expeditlono Unfortunately this was not followed up due to total breakdown of
communications between Brabant Island and. Britain. (Letters detailing the philatelic situation were sent back in March printed for use in the Second Summer and Instead of servicing FDCs steadily in basecamp in midwinter the Winter Party had to do the servicing in the last three hectic days, in pleased, seeing over \&1000 of expedition profit lost; Furse was unaware that his letters had not been received whilst Allen was unaware that they had been sent.

During the changeover the Sub Post Office was moved from Metchnikoff Point to
"Dayglo Point" 0 The Second Summer Party had brought down a number of the expedition's two

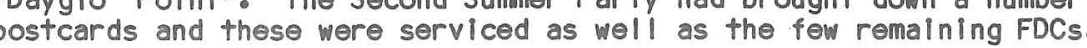

The Sub-Post office was closed on 15 March 85 and the canceller, remaining stamps
and stamp accounts were returned to the Post Office in Stanley during the return Journey. Lewis Clifton, the head of the Philatelic Bureau in Stanley was extremely helpful at all times before and during the expedition. A few misunderstandings over Registering
and handing of general philatelic mail would have been avolded if Furse had travelled out
vla stanley recelving a verbal brlef before reaching the island There is voracious worldwide interest in polar philately and First Day Covers
can provide a handsome income to help expenitions. However it is a lot of trouble. It is
essential to start very early with a dealer. preferably one specialising in the area ilke Tony Bray. It is also essential that one team member is made wholly responsible from the outset for the philatelic organisation. including keeping full accounts.

Any enquiries on expedition philatelic sales should be addressed to: Tony Bray,
Bradford Stamp Centre, 389 Thornton Road, Girlington, Bradford, West Yorkshire. 308 9BJ.
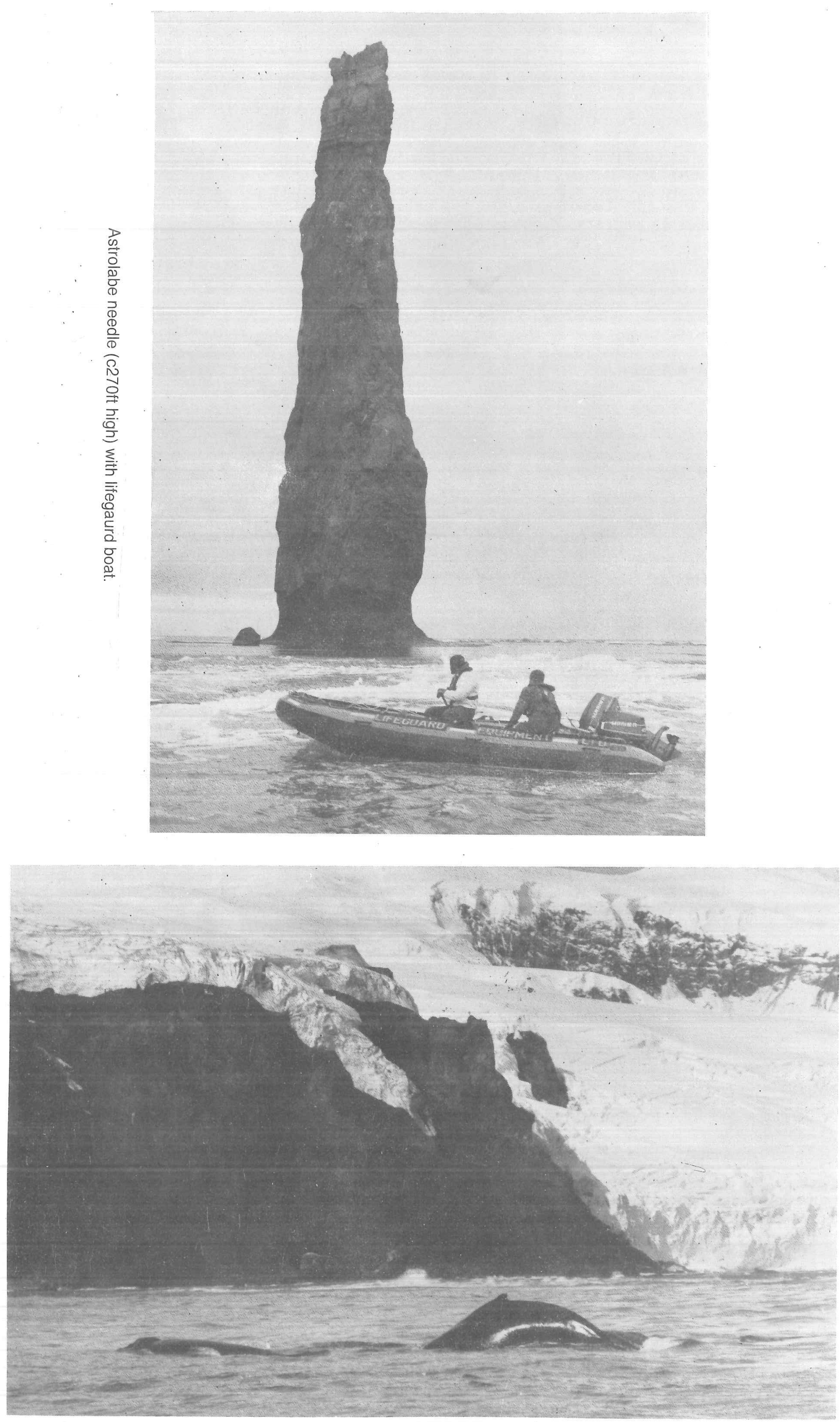

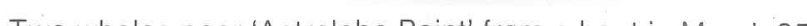




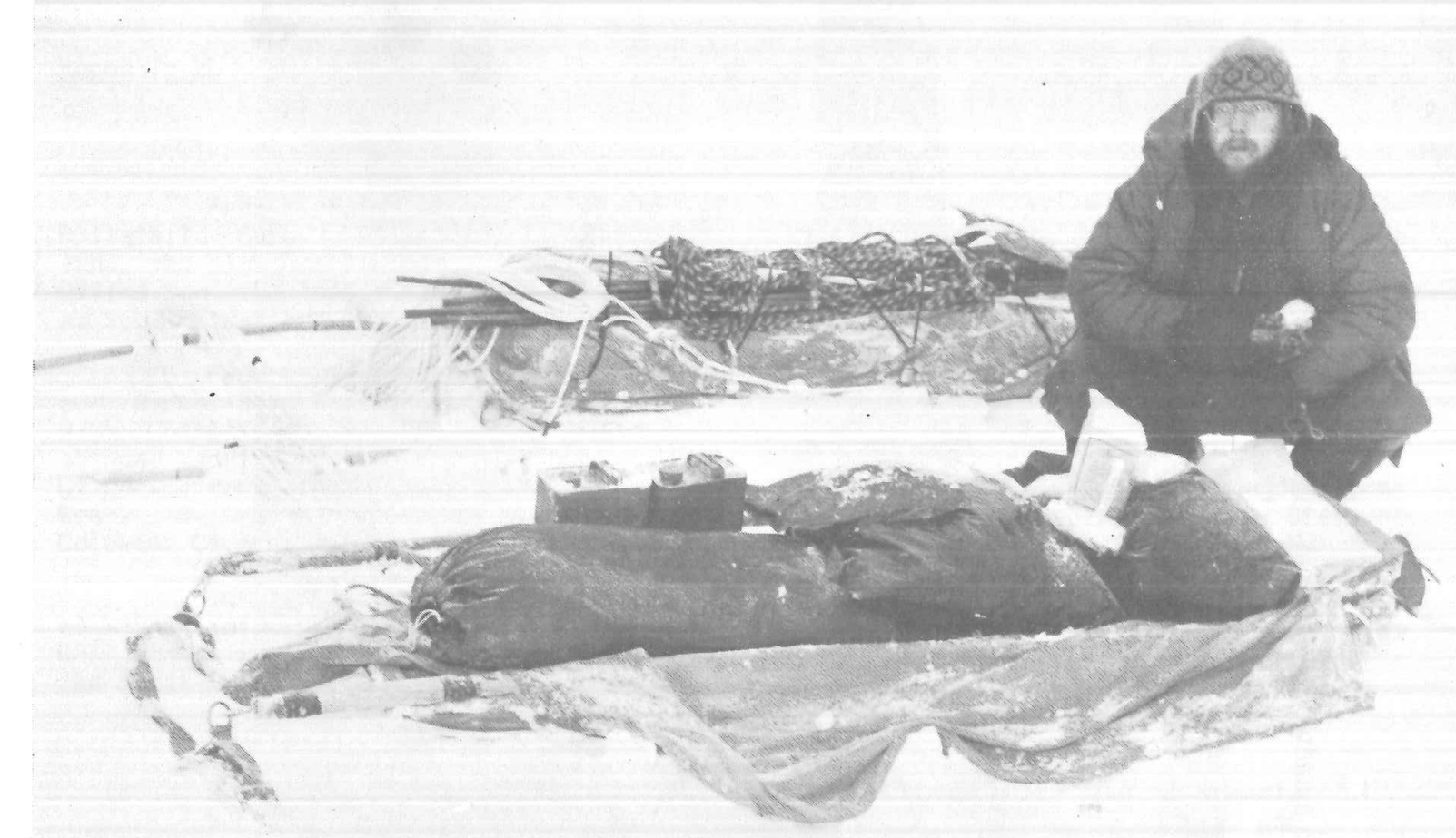

Pulk sledges. Beattie with 1-man pulks prepared for the breakout.

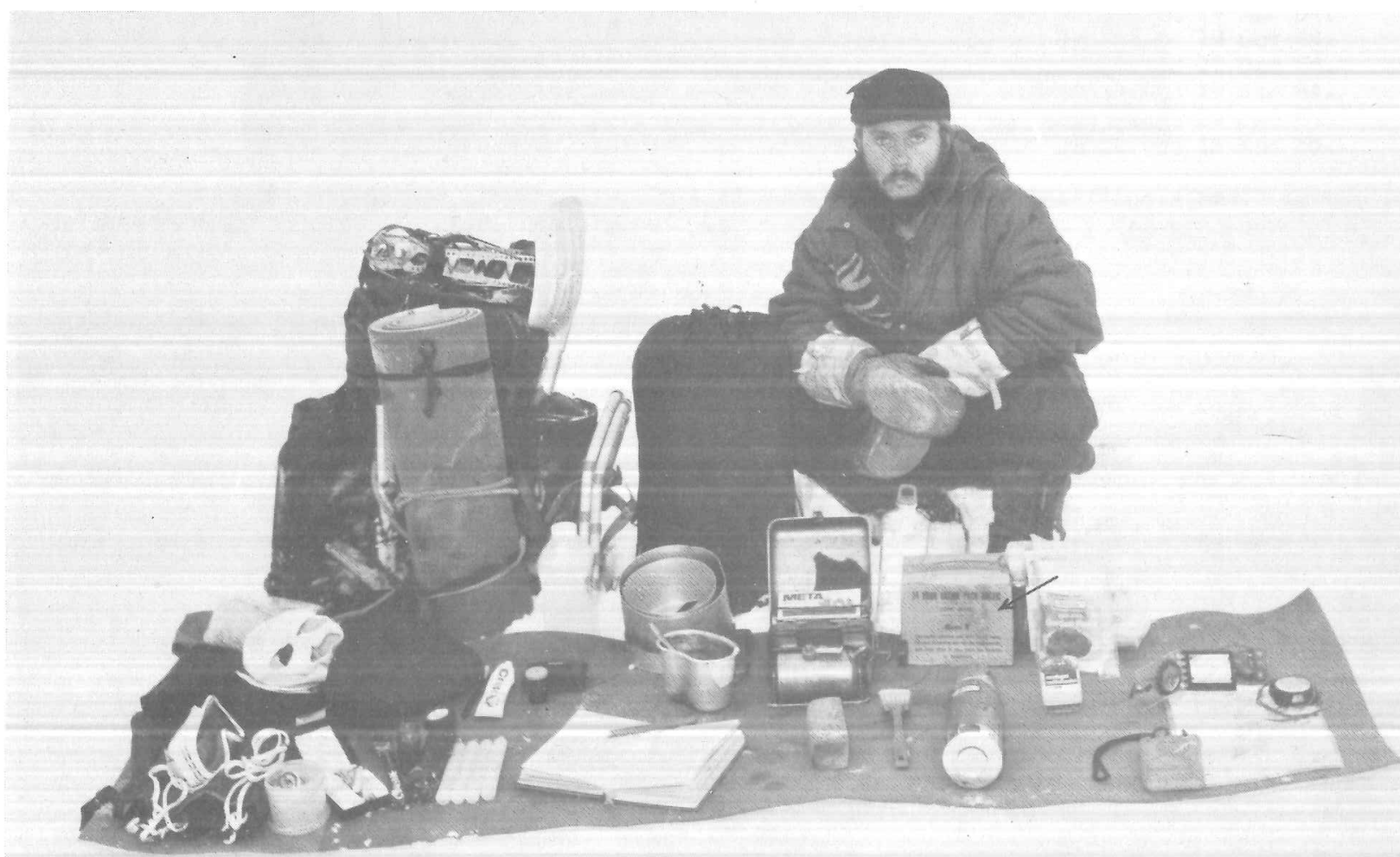

Rucksack contents. Spottiswood with typical items for travelling. (The box arrowed contains 1 manday of arctic rations).
Of three dozen team members, barely half were exper lenced winter mountaineers.
Progressive team selection continued al most unt il mbarkation Team members were in widely Progressive team selection continued almost until embarkation. Team members were in widely
scattered unitso. Therefore bulk ordering by the Expedition was chosen, despite the heary administrative load on our Equipment Officers (in sequence Waghorn, Oakley, Lewis, \& Oakley again). The onerous tasks of central packing, and subsequent unpacking, were undertaken in
sequence. by Hill, Greenway and Kimbrey. Nearly all equipment was thus obtained in bulk by
the Expedition, aithough most Individuals also took a few private items.

As an "Endorsed" JSE, we were authorised to obtain Service stores, but with very
low priority. Once a part number and tri-Service source had been I dent ifled, common consumable items were usually easy to obtain. However expensive or scarce items required two administrative stages: first the controlling authority had to be identified, to get specific approvals then the authorised demand was made on the organlsat lon holding the and Clothing Research and Development Establishment for trial: we hope the trials results will provide a valuable return to SCRDE, who gave us tremendous helpo The staff of PSTOCN support, help, advice and encouragement.

Some important items (eg tents) were not held by the Services; others (eg radios)
could not be spared for the expeditlon \& we falled to locate some sultable Service stores early enough (eg strong stores boxes). In a fell cases (eg cine cameras) we obtained Service items, and then also bought better commerclal equivalents later on, when our finances improved. We had to pay full retall price for a few items (eg Skidoos), but most
firms offered us good discounts; several made remarkably generous free loans (eg Golf il firms offered us good discounts; several made remarkably generous free
Laser Rangefinder), with a few marvel lous gifts (eg Multifab drysuits).

Our tents were very severely tested, in the summers as well as through the long
winter. Appendix $3 B$ gives brief assessments.

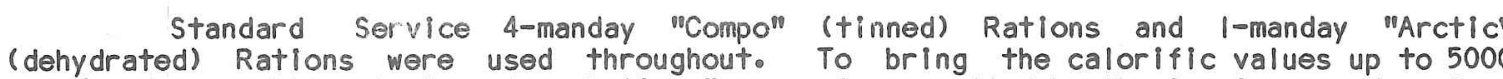
Kcal/mandy additional "Booster Rations" were also supplied by the Services and varlous goodies donated by firms were added to this booster. Our intention was to use Arctic when travelling and Compo and Booster at main dump sites. However unexpectedly difficult travel conditions produced a mismatch with our food dumps: the Winter Party therefore converted rations. This allowed us more time in the north, eating about $4000 \mathrm{Kcals} / \mathrm{manday}$ and surplus of 800 days basic rations remained for the Second Summer Party in the south

Appendices $3 \mathrm{C}$ and 30 show tabulated assessments of our food and genera equipmento To save space the columns for Manufacturers and Suppliers use codeletters the key to these ls in Items generally considered Satisfactory and Adequate in Quantity (and those where opinion were equally divided) have no entry in the "Votes" columns. Where there was a nett blas of two or more votes the netti bias is shown in the tab)

To save space most private items have been omitted from these tables. A copy Iibrary of Expedition Reports, in a bound volume, together with coples of all the detalled reports which have been prepared on individual items for manufacturerso (Such
detalled reports have been made on those items asterlsked in the narrow central column).

Most categories of speclalised items have been excluded from the tables in Appendix $3 \mathrm{~F}$ to save space (eg selentific, radio and medical equipment: skloo equi ipment, spare gear and photographic equipment; spares and special tools and repair materials for sledges, skis, huts, generators and suchlike). Appendix Two touches on these, but fuller reports are being prepared separately on several of these aspects and a bound set of those report

Most consumable items and personal clothing were resupplied for each phase t signs in the column for quantity taken (however this can only be a rough guide, of wear and tear varled widely).

During the winter phase Oakley obtalned many 24 hour temperature records in clothing and tents, and to manufacturers, and once again a complete bound set of reports
reported to SCRDE
will be lodged with the RGS. Altogether, we hope to provide a very good bank of information and comment on 
All Service Rations were packed by RNVD Botley, who also delivered them to the
point of embarkation. The RAOC Pêtroleum Centre West Moors arranged packing and freighting asoline.

With an overload in the dockyards it was not possible to arrange collection and pack ing of general stores by PSTOCN, which had been so successful on two earlier. JSE' undertake this onerous task, in an establi ishment with a large lockable store available
for recelpt, checking, sorting, and packing. HIII packed the stores for the First Summer and Overwinter Parties in the
Commando Logistic Regiment stores at RM Coypool, Plymouth. Despite having to use an open (in Portsmouth) were however inevitably difficult: if packing cannot be undertaken near the Equipment Officer, he must at least be able to visit regularly. is team members helped
in 3 final days packing. Thirteen team members (plus Greenways team of trainees from SEME) loaded the stores on board Endurance in November 83. One old lesson relearned during the First Summer was the need for good strong
boxes of a handy size for manhanding. The Second Summer Party were able to get somen
stronger boxes (and barrels) but most stores again had to be packed in collapsible plywood cases, albeit mostly of smaller (handier) sizes. It is worth making great efforts to obtain strong boxes (such as Air Portable Thomas boxes etc). As a bonus, these
a shed giving covered access to stores, plus a covered meeting place.

Greenway undertook the packing for the Second Summer Party at SEME Bordon. This was reasonably close to Portsmouth for loading onboard Endurance. Although again far away

The First Surmer Party brought back few stores. In addition to exposed film, they brough fol Summer team members distributed them). The small number of boxes returning on boar Endurance created problems with customs in Portsmouth Dockyard: after the Ships officers had overcome this travelled south again

In December 84 Ball arranged with the FI Port Auxiliary Service in Stanley the Winter Party disembarked all their return gear from Endurance Into the container, which was freighted back to UK. The Second Summer did the same with their gear
returning in March $85=$ a much better arrangement, both for Endurance and the expedition.

The Winter and Second Summer contain ners were cleared through customs in April
and May 85 respectively. Oakley arranged with PSTO(N) Portsmouth for specified boxes to (eg personal gear, SCRDE trials items, scientific samples, photographic equipment etc). The majority were despatched to RM Stonehouse, where
Kimbrey had volunteered to undertake the tedious, anti-climactic task of unpacking, cleaning up, sorting out, mustering, documenting, repacking and despatching all stores
returned. By good fortune Worrall had Just been posted there and helped. Apart from a returned. By good fortune Worrall had Just been posted there and help
fem miscellaneous items, return stores fell Into three main categories:

a. All Service equipment on loan was returned to (or through) the local PSTO(N). after assessment by a PSTO(N) Stores Inspecting Officer. Kimbrey raised the (SI26) forms for Permanent Items lost or damaged, giving the reasons (a record had been kept
while on the is land). As Euipment Officer ( $=$ Unit Supply officer) Oak ley assessed the con the forwarding to the approprite establishment stores officer or other author ity. Where
applicable, the team memer who had signed for the items was charged the approprlate amount, and was then relmbursed from the expedition funde

b. Other borrowed equipment was returned to the lenders (eg radios to Plesseys). Letters of thanks were sent, I isting the Items borrowed and returned, apologising
for any damage or losses, and in appropriate cases of fering (reticentlyl) to make

c. Equipment belonging to the Expedition (commerclal purchases and gifts) was simllar personal gear. Several expensive, durable items were passed to suitable organisations, to be avallable for other JSEs (eg canoes to RN Kayak Association). Most other items (eg liceaxes) were sold by the expedition to team members at a
reasonable second hand price, thus helping to finance the concurrent expenditure on

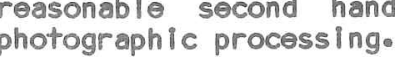

The first to spend a complete year living in tents in Antarctica,
applied the most severe test that modern tents have ever been subjected to.

All British manufacturers were canvassed, plus several Continental oneso However
with a few exceptions, the response was disappointingly (often understandably) negative. In the event we managed to live in reasonable comfort, despite blowouts and
burlals. Our main basecamp tents were outstanding. Our maln moblle tents also proved good enough, and popular.

Full technical reports on all tents are being passed to the manufacturers.
Coples of all these reports will be lodged in the RGS, bound with the other equipment reports. The table over leaf shows the useage of the varlous types through the year. The much more than 93 years normal useage of a tent in Europe. Brief comments on each type 2-man Antarctic Pyramid Tents. (MFC Survival). Superby manufactured main basecamp tents,
as used by BAS, with ventile cotton outers. Proved bombproof in winds over $100 \mathrm{knots}$
without protection. Formed 6 fit windscoops, heavy drifting never occurred as snowwalls without protection.
unnecessary. Very comfortable for 2 , but rather inconvenient for 30 Too large and heavy for pulks, needs apex storm guy to he ip erection in Force 8 ; currentiy unsuitable for rock
or ice sites; worth the great expense. Manufacturer responded well to our very few, very
minor suggestions. $\frac{\text { Super Nova \& Nova Dome Tentso }}{\text { liked despite several problems. Suntergear/WIId Country). Light mobile tents, very well }}$ strength. Unmodified tents without snowwalis blew out in gusts above 55 knots; with survived over 100 knots. Outstanding arodynamics formed $6 \mathrm{ft}$ windscoops withstood complete burial very well indeed. Very convenient; very comfortable for 2 and reasonable for 3. poles easily broken; very tricky to erect in Force 8; frozen pole elastics troublesome in winter: outer tore easily; many spare poles essentialo
Manufacturer has already incorporated suggestions for stormguys and double poles. Mountain Dome Tents. (Wintergear/Wild Country). Developed from the Super Nova, these outer). Appeared stronger than the Super Novas and equally conveniente Second Summer found light summer poles less llable to break during erection than heavy duty poles, and used double suncer prom improvements:- to the standard tent, plus extra improvements for an expedition vers lon, plus
inter optional extras available with either.

$\frac{\text { Snowl ine Conquest Box Tentse }}{\text { Continental Tents). A very strong and Well made pulking tent, that could coment, formerly }}$ Force 10 winds. Withstood winds of 100 knots without protection. Reasonable windscoop
formed, and probably reasonable in drifts but only tested to half hel ghto Rather cramped outstandingly helpful throughout, (in fact some problems were due to their incorporating our suggestions). They are already incorporating the improvements suggested to reduce condensation and weight, to eradicate a problem on the end crosspoles, and to increase

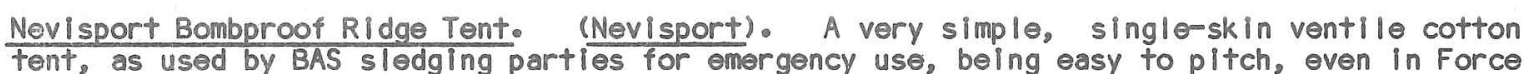
12. Easily withstood winds over 80 knots without snow-wall. Needs frequent di ging out to maintain room inside. Small for 2 men. Very expensive; too heavy for long pulk Journeys:
condensation bad in freezing rain. Manufacturer is helpful, and cost is greatly reduced if

Force 10 Mark 5 Ridge Tent. (Vango). This three A-pole version had a rather stronger 60 knots without snownalls, but poles broke in heavier gusts. Needed frequent digging out as drifts over $3 \mathrm{ft}$ threatened collapse. Very convenient for 2 men; comfortable for 3 s possible with 4o. With snowpit the outer made a useful skidoo garage. Usual ridge-tent
wind and drift problems; weak poles; poor zips; careless finish. Manufacturer would only

Phortress Ridge Tento (Phoenix). A light, small tent, neatly designed, well-made and easy under drifts, and poles broke. Very cramped for two men despite the excellent bell-ends: nevertheless outer used for 4-man bivouace Not really strong enough for these conditions,
and too small for dry comfortable living. Manufacturer concentrates on popular standard
models, not specials for expeditions. 
Gresshoppe Pyramide. These had been made in Norway, and were old second hand tents from
the Belglan Antarctic expeditions. Similar to MFC survival tents but with corner poles sleeved in outer, making simple apex arrangement easily fitted with storm guy(s). However very small inside. Withstood
bent double and tent collapsed.

Maureen Dome (Maureen Hardy) A beautifully made prototype, it was restricted to basecam use because of the large number of guys neededo. Poles in outer tent reduced damage when poles broke; however this and radial (as opposed to geodest
small and inconvenient. Very helpful individual manufacturer.

Expedition Special Alu Pyramid Tento. (Fjall raven) Small centre-pole pyramids, very light to carry but only used in bisecamp due to many weaknesses. inconvenient centre pole, and entrance poor in wind and snow. Not strong enough, but outer The Tent (U1timate). Used brlefly in the Second Summer, but inspired no confidence an small, so not tested in rigorous conditions.

other Types. Two types of light-weight kiddie tents were donated to the expedition. One of them was erected for trial, but blew down the first night in a mere galeo We were grateful for the donations, and the manufacturers.

TABLE: USEAGE OF TENTS (IN TENT-MONTHS, ROUNDED UP)

\begin{tabular}{|c|c|c|c|c|c|c|}
\hline TENT & $\begin{array}{c}\text { NUMBERS } \\
\text { TAKEN } \\
\text { SOUTH } \\
\text { 1S+OW+2S } \\
\end{array}$ & $\begin{array}{l}1 S \\
J F M \\
\text { J o a } \\
\text { in } b \text { r }\end{array}$ & 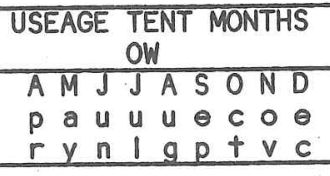 & 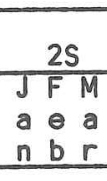 & $\begin{array}{l}0 \\
\text { T } \\
\text { A }\end{array}$ & $\begin{array}{l}\text { MAXIMUM } \\
\text { USEAGE } \\
\text { ANY ONE } \\
\text { TENT. }\end{array}$ \\
\hline FC ANTARCTIC & $5+0+0$ & $31-$ & $-144411-3$ & 11 & 28 & 9 MONTHS \\
\hline 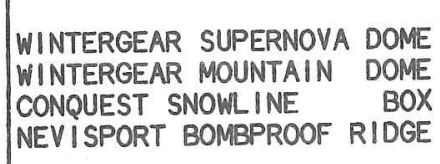 & $\begin{array}{l}22+12+0 \\
0+0+4 \\
5+0+0 \\
1+0+0\end{array}$ & $\begin{array}{l}225 \\
=-1 \\
=1\end{array}$ & & $\begin{array}{rr}2 & 22 \\
2 & 42 \\
- & -1\end{array}$ & $\begin{array}{r}50 \\
8 \\
5 \\
4\end{array}$ & $\begin{array}{l}5 \text { MONTHS } \\
2 \text { MONTHS } \\
2 \text { MONTHS } \\
2 \text { MONTHS }\end{array}$ \\
\hline $\begin{array}{l}\text { VANGO FORCE } 10 \text { MKS RIDGE } \\
\text { PHOENX PHORTRESS RIDEE } \\
\text { GRESHOPPE TOLDI PYRAMID }\end{array}$ & $\begin{array}{l}4+0+0 \\
4+0+0 \\
2+0+0 \\
1+0+0 \\
4+0+0 \\
0+0+3 \\
3+0+0\end{array}$ & $\begin{array}{ll}- & \\
& \end{array}$ & & & $\begin{array}{l}3 \\
3 \\
1 \\
1 \\
2 \\
1 \\
1\end{array}$ & $\begin{array}{l}1 \text { MONTH } \\
1 \text { MONTH } \\
1 \text { MONTH } \\
1 \text { MNNTH } \\
2 \text { WEEKS } \\
1 \text { WEEK } \\
1 \text { NIGHT }\end{array}$ \\
\hline
\end{tabular}

Mobile Pyramid Tentse We belleve that the best design to combine good resistance to wind and drifting with easy erection in high winds remalns the pyramid (with four sleeved corner poles, and provision for a storm guy from the apex .
(with sectional poles and both tube and zipped entrances) and they proved excellent on Elephant Island in 1976/77. However UItimate declined to make a batch of 16 for Brabant I s land, and widespread enquiri les failed to identify another such tento There
Appendix 3D

For the overwintering, a hut was wanted as a laboratory, casualty station and place for team meetings. When the support of HMs Endurance was
obtained two huts which could be transported in kit formo

Triwall Hut, orected in March 1984 at Metchnikoff Pointo. Mr Michael Lethbridge specially foldad $\frac{1}{2}{ }^{\circ}$ thick Triwall thicknesso. The floor was of I" marine plywood. Triwall generously supplled the materia free, and the hut was prefabricated at RE Chattenden by Sapper Brandon. with Evostik Flashbande. Stuttard then built a porch with a floor area of $4 \times 4$ ft, plus storage space in the plycase walls, and a door lopening inward for safe exit in drifts). The Triwall hut was used throughout our time lin lasecamp, as a laboratory, postoiftce, radio It required considerable makeshift stiffening by scaffolding and wooden skis etc to withstand winde. After comfortably surviving burlal overwinter, the hut began to crack between roof and ent walls when re-exposed to whds in Decembere the right time. We could not recommend similar huts for future expeditions, but this one served us outstandingly.

Structaply Hut, erected in January 1985 at "Davglo Point"no. This cube-shaped prefabricated insulated walls and roof. Structaply were recommended to us by BAS. The cumberson $4 \times 814$ sectlons proved difficult underslung loads, but were flown ashore in February 1984 place, post office and radio shed: it was also used as a casualty station for Greenway for 5 days. Although much of the wood was untreated and found soggy, it should survive severa years. This Hawker Stade the as a Refuge Hut

Union Garage, built in April 1984 at Metchnikoff Pointo Kimbrey and Atkins spent a week buling a pitched roof was made with a scaffolding ridgepolo and rafters of wooden skis covered with Triwall packing case materlal. It proved invaluable as a workshop. The "Union Garage" survived burial well over the winter, and is expected to boxes.

Triwall Boxeso In winter large Triwall packing cases proved useful shelters (for skidoo bottom side cut and flapped out as a snow valence, box modules could be joined up. They
lasted a few months each, and the abllity to move them about and $11 \mathrm{ft}$ them to the top of Recommendation. Wintering in tents was found quite practical. Nevertheless the tean

c. A scientific laboratory.
d. A casualty station.

It was also heartlly agreed that a covered storage area was essential, to avoid repetitive digging for buried gear

At low level in this region snowholes or icecaves would be impractical over the thering thas.

The consensus was that the ideal for such a light expedition would be to take
stores in wooden boxes strong enough to build into walls, with their open tops facing inward as storage space. A few wooden battens or planks would also be required to use as bolted stiffeners and to support a tarpaulin or strong PVC roof. Two spaces back-to back are desirable, one dedlcated as a workshopo panels sul rable for dosis are neases or larch Trlwall boxes, (and some stiffening battens) are adequate, and enable upward extension as the hut is drifted over, to minimise the time spent digging out the entrance. 
SERVICE "COMPO" RATIONS, in 4-manday packs, used in basecamps.

Weight approx 20 lbs per 4-mandays.
Calorific content about $3900 \mathrm{kcal}$ per manday (including biscuit).

\begin{tabular}{|c|c|c|c|c|}
\hline \multirow[b]{2}{*}{ ITEM } & \multirow[b]{2}{*}{ MENU } & \multirow{2}{*}{$\begin{array}{l}\text { QUALITY } \\
\quad \text { VOTES } \\
+ \text { Excell lent } \\
: \text { Satisfact } \\
- \text { Poor } \\
\text { Winter only } \\
\text { max } 10 \text { vote }\end{array}$} & \multirow[b]{2}{*}{$\begin{array}{c}\text { QUANTITY } \\
\text { per } \\
\text { 4-Manday Pack }\end{array}$} & \multirow{2}{*}{$\begin{aligned} & \text { QUANTITY } \\
& \text { VOTES } \\
&+ \text { More neede } \text { M Adequate } \\
&- \text { Too much } \\
& \text { Winter only } \\
& \text { max } 10 \text { vote }\end{aligned}$} \\
\hline & & & & \\
\hline $\begin{array}{c}\text { Breakfast. Baked beans, tomato sce } \\
\text { Sausages } \\
\text { Bacon-grill } \\
\text { Baconburgers } \\
\text { Beefburgers } \\
\text { Luncheon-meat } \\
\end{array}$ & $\left|\begin{array}{cc}A B C D E F G \\
A C C E & G \\
B & F \\
& D \\
A & D F \\
A & D\end{array}\right|$ & $\begin{array}{r}10+ \\
9+ \\
2+ \\
2+ \\
2+ \\
7+ \\
\end{array}$ & 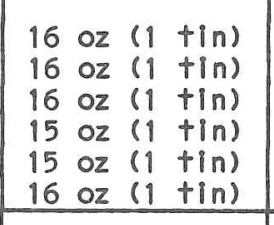 & $\begin{array}{l}9+ \\
9+ \\
4+ \\
6+ \\
\vdots \\
4+\end{array}$ \\
\hline $\begin{array}{l}\text { Drinks. Teabags } \\
\text { Instant coffee } \\
\text { sugar } \\
\text { Instant powdered skimmed milk } \\
\end{array}$ & $\begin{array}{l}\text { ABCDEFG } \\
\text { ABCDEFG } \\
\text { ABDEEFG } \\
\text { ABCDEFG } \\
\end{array}$ & $\begin{array}{l}5+ \\
4+ \\
2+ \\
2+ \\
\end{array}$ & 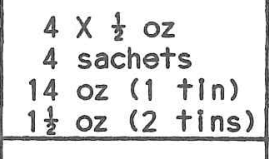 & $\begin{array}{l}6+ \\
8+ \\
6+ \\
5+ \\
5+\end{array}$ \\
\hline \begin{tabular}{|c|} 
Supper.Powdered soups.Mushroom \\
Mulligatawny \\
Chicken \\
Oxtail \\
Green pea \\
Vegetable \\
Meats.Goul ash \\
Corned beef \\
Steak \& onlon casserole \\
Chicken curry \\
Steak \& kidney pudding \\
Chicken in brown sauce \\
Stewed steak \\
Vegetables.carrots \\
Mixed vegetables \\
Processed peas \\
Mashed potato powder \\
Pre-coked rice \\
PuddingsoApple pudding \\
Rice pudding \\
Mixed fruit pudding \\
Frult sal ad \\
Pears \\
Paaches \\
Apricots \\
\end{tabular} & 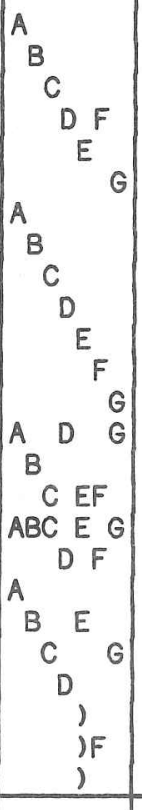 & $\begin{array}{c}4+ \\
-3 \\
2+ \\
-10 \\
3+ \\
5+ \\
\vdots \\
9+ \\
9+ \\
1+ \\
4+ \\
-4 \\
\vdots \\
5+ \\
3+ \\
-5 \\
-5 \\
8+ \\
-1 \\
-1 \\
5+ \\
9+ \\
7+ \\
9+ \\
4+ \\
4\end{array}$ & 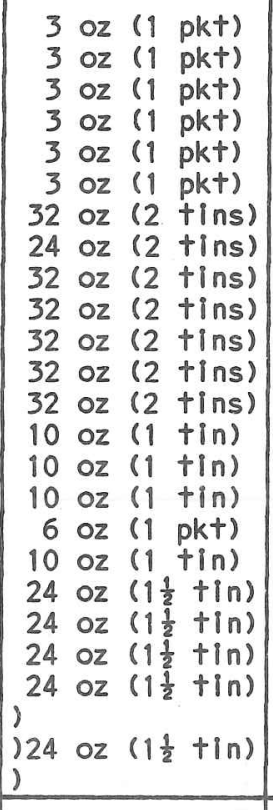 & $\begin{array}{c}-1 \\
-2 \\
-2 \\
-9 \\
-1 \\
1+ \\
-1 \\
3+ \\
\vdots \\
-2 \\
-3 \\
-3 \\
1+ \\
4+ \\
2+ \\
-1 \\
2+ \\
-3 \\
\vdots \\
2+ \\
8+ \\
6+ \\
6+ \\
3+ \\
\end{array}$ \\
\hline 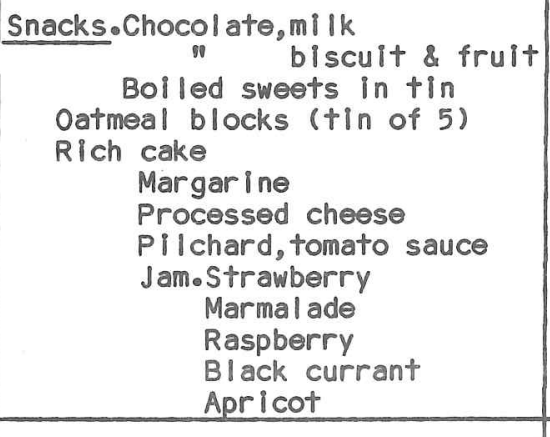 & 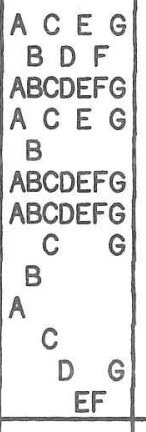 & $\begin{array}{c}5+ \\
\vdots \\
\vdots+ \\
8+ \\
10+ \\
5+ \\
7+ \\
-2 \\
9+ \\
5+ \\
7+ \\
9+ \\
5+ \\
+\end{array}$ & 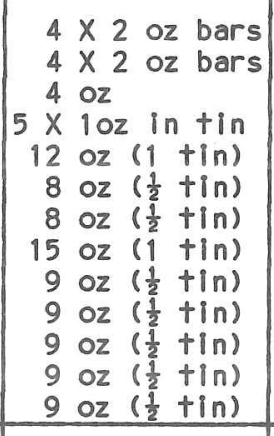 & $\begin{array}{c}5+ \\
5+ \\
-7 \\
5+ \\
8+ \\
\vdots \\
6+ \\
-8 \\
\vdots \\
1+ \\
\vdots \\
2+ \\
: \\
\end{array}$ \\
\hline $\begin{array}{r}\text { From Bulk supplement.vitamin tab } \\
\text { Biscults AB (plain, hard) }\end{array}$ & $\begin{array}{l}\text { ABCDEFG } \\
\text { ABCDEFG } \\
\end{array}$ & $7+$ & $\begin{array}{l}11 \text { tablet } \\
\text { c8 oz } \\
\end{array}$ & $4+$ \\
\hline $\begin{array}{l}\text { Miscell aneous.Salt } \\
\text { Mustard } \\
\text { Jiffy tin-opener } \\
\text { Plastic reclosure tin-lids } \\
\text { Matches (book, in sweet-tin) } \\
\text { Toilet paper }\end{array}$ & $\begin{array}{l}\text { ABCDEFG } \\
\text { ABCDEFG } \\
\text { ABCDEFG } \\
\text { ABCDEFG } \\
\text { ABCDEFG } \\
\text { ABCDEFG }\end{array}$ & $\begin{array}{l}1+ \\
2+ \\
9+ \\
9+ \\
-4 \\
-8\end{array}$ & $\begin{array}{l}1 \text { oz bottle } \\
\frac{1}{4} \text { oz ( } 1 \text { pkt) } \\
\text { one } \\
\text { two } \\
1 \text { book let } \\
24 \text { sheets } \\
\end{array}$ & $\begin{array}{c}-9 \\
2+ \\
\vdots \\
4+ \\
4+ \\
4+\end{array}$ \\
\hline
\end{tabular}

SERVICE "ARCTIC" RATIONS (Dehydrated). In 1-manday packs, used on the hill. Welaht ap pox 3 ths Roy naval Victualling Depot, Botley. Calorific content about $4500 \mathrm{kcals}$ per mencla

\begin{tabular}{|c|c|c|c|c|}
\hline \multirow[b]{2}{*}{ ITEM } & \multirow[b]{2}{*}{$\begin{array}{l}\text { MENU } \\
\text { ABCD }\end{array}$} & \multirow{2}{*}{\begin{tabular}{|c|} 
QUALITY \\
VOTES \\
+ Excell \\
$:$ Sant Isfact \\
- Poor \\
Winter only \\
max 10 vote
\end{tabular}} & \multirow[b]{2}{*}{$\begin{array}{c}\text { QUANTITY } \\
\text { per } \\
\text { 1-Manday Pack }\end{array}$} & \multirow{2}{*}{$\begin{aligned} & \text { QUANTITY } \\
& \text { VOTES } \\
&+ \text { More needed } \\
&: \text { Adequate } \\
&- \text { Too much } \\
& \text { Winter only } \\
& \text { max } 10 \text { votes }\end{aligned}$} \\
\hline & & & & \\
\hline \begin{tabular}{|} 
BreakfastoPorridge. \\
Apple flakes \\
Apple \& apricot flakes \\
Drinking chocolate \\
\end{tabular} & $\begin{array}{l}A B C D \\
A C D \\
B D D \\
A B C D \\
\end{array}$ & $\begin{array}{r}5+ \\
8+ \\
10+ \\
8+ \\
\end{array}$ & $\begin{array}{rll}3 \frac{1}{2} & 0 z \\
1 & 0 z \\
1 & 0 z \\
2 \frac{1}{2} & 0 z \\
\end{array}$ & $\begin{array}{l}2+ \\
7+ \\
7+ \\
4+ \\
4\end{array}$ \\
\hline 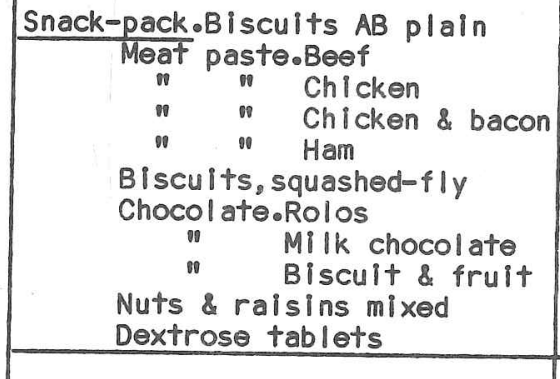 & $\begin{array}{l}A B C D \\
A \\
B \\
C \\
C D \\
A B C D \\
A B C D \\
A C \\
B D \\
A B C D \\
A B C D \\
\end{array}$ & $\begin{array}{l}3+ \\
2+ \\
2+ \\
5+ \\
4+ \\
6+ \\
8+ \\
3+ \\
7+ \\
5+ \\
2+\end{array}$ & 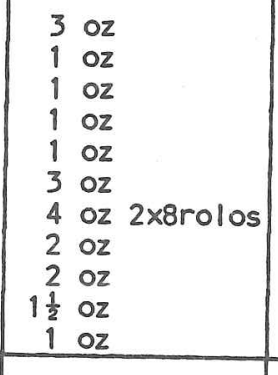 & $\begin{array}{c}2+ \\
3+ \\
3+ \\
3+ \\
3+ \\
2+ \\
-3 \\
-1 \\
3+ \\
\vdots \\
-2 \\
\end{array}$ \\
\hline $\begin{array}{l}\text { Drinks. Instant tea } \\
\text { Instant coffoe } \\
\text { Beef stock } \\
\text { Sugar } \\
\text { Powdered skimmed mllk } \\
\end{array}$ & $\begin{array}{l}A B C D \\
A B C D \\
A B C D \\
A B C D \\
A B C D \\
\end{array}$ & $\begin{array}{l}4+ \\
9+ \\
1+ \\
-4 \\
8+ \\
\end{array}$ & 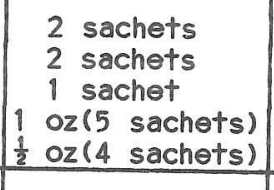 & $\begin{array}{r}5+ \\
8+ \\
\vdots \\
7+ \\
3+ \\
\end{array}$ \\
\hline $\begin{array}{c}\text { Main meal. Soup.Chicken } \\
\text { n Vegetable } \\
\text { ox oxtail } \\
\text { Meat granules.Be日f } \\
\text { Curried beef } \\
\text { Mutton } \\
\text { Chicken Supreme } \\
\text { Mashed potato powder } \\
\text { Pre-cooked rice } \\
\text { Freoze-dried peas } \\
\end{array}$ & $\begin{array}{l}A \\
B D D \\
{ }^{A} C \\
A B \\
B \\
C \\
C D \\
A C D \\
B D \\
A B C D \\
A C D\end{array}$ & $\begin{array}{c}2+ \\
6+ \\
-9 \\
4+ \\
10+ \\
-4 \\
6+ \\
-2 \\
10+ \\
6+ \\
\end{array}$ & $\begin{array}{ll}1 & o z \\
1 & o z \\
1 & o z \\
1 & o z \\
2 & o z \\
2 & o z \\
2 & o z \\
2 & o z \\
2 & o z \\
2 & o z \\
3 & o z \\
1 \frac{1}{2} & o z \\
\end{array}$ & $\begin{array}{l}-1 \\
2+ \\
-7 \\
5+ \\
5+ \\
-2 \\
1+ \\
5+ \\
2+ \\
-5 \\
\end{array}$ \\
\hline From Bulk Supplement.vitamin tab & $A B C D$ & $\therefore$ & one & $:$ \\
\hline $\begin{array}{l}\text { Sundries.Salt } \\
\text { Booklet of matches } \\
\text { Handy-Andy paper tissues } \\
\text { Tollet paper } \\
\text { Wooden spatula } \\
\end{array}$ & $\begin{array}{l}A B C D \\
A B C D \\
A B C D \\
A B C D \\
A B C D \\
\end{array}$ & $\begin{array}{r}1+ \\
-5 \\
9+ \\
-7 \\
:\end{array}$ & {$\left[\begin{array}{cc}1.25 \text { grams } \\
1 & \text { book let } \\
1 & \text { packet of } 6 \\
10 & \text { sheets } \\
\text { one }\end{array}\right.$} & $\begin{array}{c}-7 \\
1+ \\
\vdots \\
-2 \\
\end{array}$ \\
\hline
\end{tabular}


BULK RATIONS.
Bulk supplement provided by DGST(N).82, through RNVD Botley (Rh), to make up rations to $5000 \mathrm{kcals}$ per manday o intended to be used as a booster Additional "Goodies" provided by various helpful firms - used in the same way.
Bulk rations were landed at Metchnikoff Point, "Dayglo point" and "Astrolabe Point". They were not distributed in exact proportion to the time spent work
out of each of these sites (eg only the Dayglo Party sam Mars Bars).

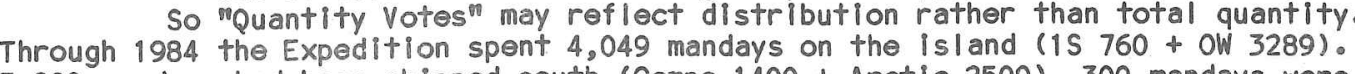
3,900 mandays had been shipped south (Compo $1400+$ Arctic 2500). 300 mandays were 220 mandays Compo in November 84 . So a total of 4,120 mandays basic ratlons were landedo However 600 mandays remal ined unused at Dayglo pointo, and 96 mandays were lost from "Astrolabe Point". The teams ate 3,424 mandays rations in 4,049 mandays.
The Bulk Rations therefore proved absolutely essential, to make up the deficito

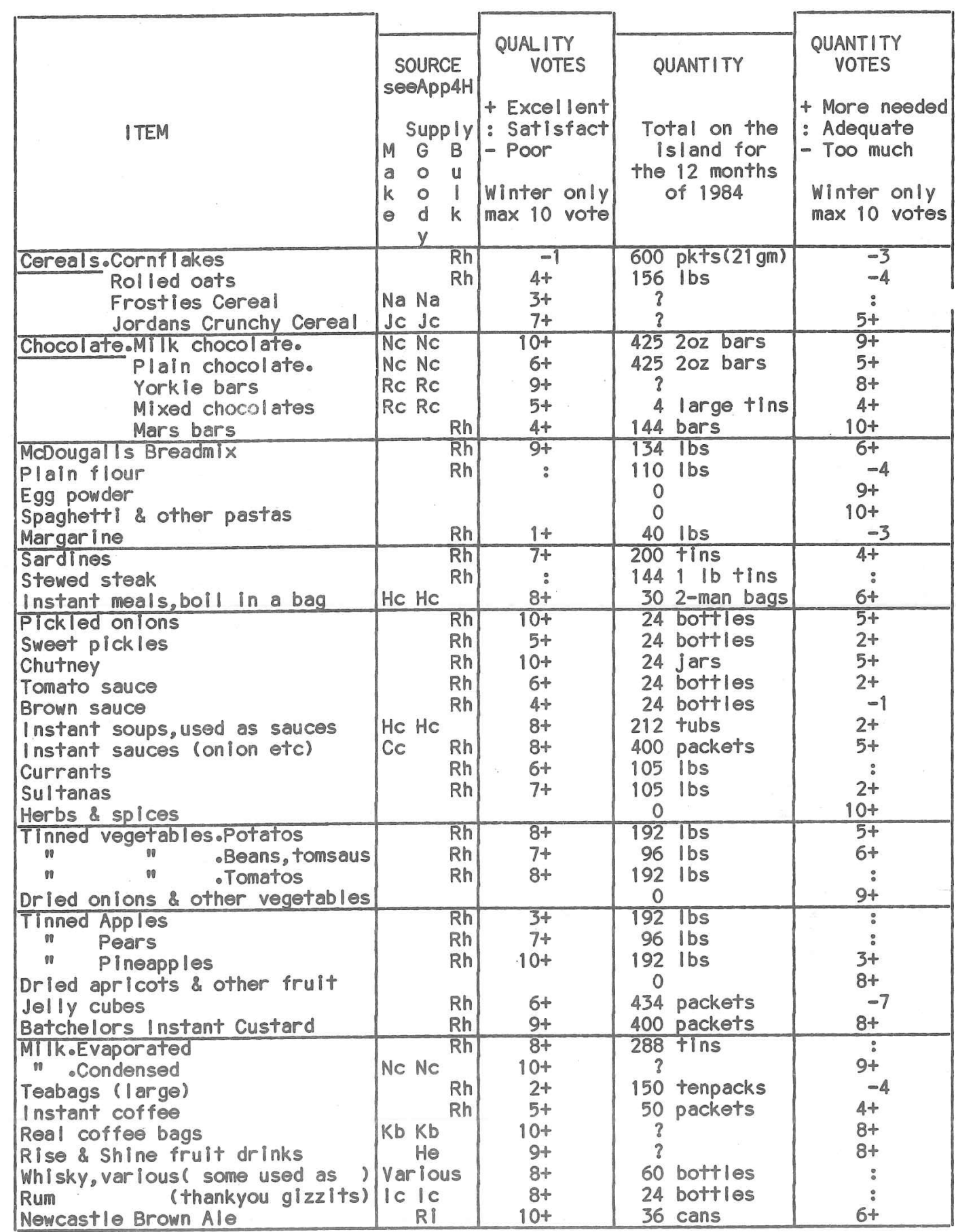
Rum

\begin{tabular}{|c|c|}
\hline $\begin{array}{l}\text { Limpets (boll add pepper etc) } \\
\text { Antarctle Cod (fry or boil) } \\
\text { Chinstrap breast (marinate, fry) } \\
\text { Chinstrap egg (fry, omelette) }\end{array}$ & $\begin{array}{l}2+ \\
2+ \\
3+ \\
6+\end{array}$ \\
\hline
\end{tabular}

\begin{tabular}{|c|c|c|c|c|c|c|c|c|c|c|}
\hline \multirow{4}{*}{ ITEM } & & \multicolumn{3}{|c|}{$\underline{\text { CLOTHING. }}$} & & & & & & \\
\hline & $\begin{array}{l}\text { SOURCE } \\
\text { se日APP4H }\end{array}$ & \multirow{2}{*}{\multicolumn{2}{|c|}{$\begin{array}{l}\text { QUALITY } \\
\text { VOTES } \\
+ \text { Excellent } \\
\text { : Satisfact } \\
\text { - Poor }\end{array}$}} & \multirow{3}{*}{$\begin{array}{ll}R \\
G \\
S \\
R \\
\theta \\
P \\
0 \\
\\
\end{array}$} & \multicolumn{4}{|c|}{ QUANTITY TAKEN } & \multirow{2}{*}{\multicolumn{2}{|c|}{$\begin{aligned} & \text { QUANTITY } \\
& \text { VOTES } \\
&+ \text { More needed } \\
&: \text { Adequate } \\
& \text { Too much } \\
&\end{aligned}$}} \\
\hline & & & & & \multirow{2}{*}{$\begin{array}{l}D \\
E \\
N \\
0 \\
M\end{array}$} & \multirow{2}{*}{$\begin{array}{l}15 \\
10 \\
\text { men }\end{array}$} & \multirow{2}{*}{$\begin{array}{l}\text { ow } \\
12 \\
\text { men }\end{array}$} & \multirow{2}{*}{$\begin{array}{l}25 \\
17 \\
\text { men }\end{array}$} & & \\
\hline & $\begin{array}{l}M \\
a \\
k \\
e\end{array}$ & \begin{tabular}{|l|}
15 \\
$\max 7$
\end{tabular} & $\underset{\max 10}{\mathrm{OW}}$ & & & & & & $\begin{array}{l}15 \\
\max 7\end{array}$ & OW 10 \\
\hline $\begin{array}{l}\text { Stockings. Arctic RM white inner } \\
\text { Survival Aids inners } \\
\text { Red loopstitch outers } \\
\text { Civililan loopstitch outers } \\
\end{array}$ & $\begin{array}{l}\mathrm{Lf} \\
S K \\
\mathrm{Ra}\end{array}$ & $\begin{array}{l}6+ \\
6+\end{array}$ & $\begin{array}{c}10+ \\
7+ \\
10+\end{array}$ & $\begin{array}{l}* \\
* \\
*\end{array}$ & $\begin{array}{l}\mathrm{pr} \\
\mathrm{pr} \\
\mathrm{pr} \\
\mathrm{pr}\end{array}$ & $\begin{array}{r}40 \\
0 \\
40 \\
0 \\
\end{array}$ & $\begin{array}{r}24 \\
32 \\
24 \\
0 \\
\end{array}$ & $\begin{array}{r}0 \\
0 \\
0 \\
80 \\
\end{array}$ & $\begin{array}{c}\vdots \\
\vdots \\
\vdots\end{array}$ & $\begin{aligned}: \\
4+ \\
2+ \\
:\end{aligned}$ \\
\hline $\begin{array}{l}\text { Pants. Service ECW longjohns } \\
\text { Madalis wool longjohns } \\
\text { Helly Hansen Lifa thermal longjohns } \\
\text { Tog } 24 \text { thermal longjohns } \\
\text { Viloft thermal longjohns } \\
\text { Peter Storm thermal longj ohns } \\
\text { Damart thermal longjohns } \\
\text { Bridgedale longjohns } \\
\end{array}$ & $\begin{array}{ll} & L f \\
\mathrm{Db} & \mathrm{Db} \\
\mathrm{Hd} & \mathrm{Hd} \\
\mathrm{TC} & \mathrm{TC} \\
\mathrm{Pb} & \mathrm{Pb} \\
\mathrm{Ga} & \mathrm{Ga} \\
\mathrm{Cf}\end{array}$ & $3+$ & $\begin{array}{l}2+ \\
\vdots \\
5+ \\
2+ \\
2+ \\
3+ \\
1+\end{array}$ & $\begin{array}{l}* \\
* \\
* \\
* \\
*\end{array}$ & $\begin{array}{l}\mathrm{pr} \\
\mathrm{pr} \\
\mathrm{pr} \\
\mathrm{pr} \\
\mathrm{pr} \\
\mathrm{pr} \\
\mathrm{pr} \\
\mathrm{pr}\end{array}$ & $\begin{array}{r}10 \\
8 \\
3 \\
0 \\
0 \\
3 \\
0 \\
0 \\
\end{array}$ & $\begin{array}{r}12 \\
1 \\
7 \\
1 \\
2 \\
2 \\
1 \\
0 \\
\end{array}$ & $\begin{array}{r}20 \\
0 \\
0 \\
10 \\
0 \\
0 \\
0 \\
5 \\
\end{array}$ & $\begin{array}{c}-7 \\
\vdots \\
\vdots \\
\vdots \\
\vdots \\
\end{array}$ & $\begin{array}{l}-5 \\
2+ \\
1+ \\
1+ \\
1+ \\
1+ \\
:\end{array}$ \\
\hline $\begin{array}{l}\text { Vests (long-sleeved). Service ECW. } \\
\text { Madalis woollen } \\
\text { Helly Hansen Lifa thermal } \\
\text { Tog } 24 \text { thermal } \\
\text { Viloft thermal } \\
\text { Peter Storm thermal } \\
\text { Bridgedale }\end{array}$ & $\begin{array}{ll}\mathrm{Db} & \mathrm{Lf} \\
\mathrm{Db} & \mathrm{Db} \\
\mathrm{Hd} & \mathrm{Hd} \\
\mathrm{TC} & \mathrm{TC} \\
\mathrm{Pb} & \mathrm{Pb} \\
& \mathrm{Cf} \\
\end{array}$ & $:$ & $\begin{array}{l}2+ \\
1+ \\
5+ \\
2+ \\
1+ \\
3+\end{array}$ & 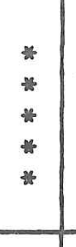 & $\begin{array}{l}\text { no } \\
\text { no } \\
\text { no } \\
\text { no } \\
\text { no } \\
\text { no } \\
\text { no } \\
\end{array}$ & $\begin{array}{r}10 \\
3 \\
3 \\
0 \\
0 \\
0 \\
0 \\
0\end{array}$ & $\begin{array}{r}12 \\
3 \\
7 \\
3 \\
1 \\
4 \\
0 \\
\end{array}$ & $\begin{array}{r}20 \\
0 \\
0 \\
10 \\
0 \\
0 \\
5 \\
\end{array}$ & $\begin{array}{c}-7 \\
\vdots \\
\vdots \\
\vdots \\
\end{array}$ & $\begin{array}{l}3 \\
3+ \\
1+ \\
1+ \\
1+ \\
1+ \\
\vdots \\
\end{array}$ \\
\hline $\begin{array}{l}\text { Shirts. Army flannel } \\
\text { Norweglan army } \\
\text { Nevisport woollen }\end{array}$ & $\begin{array}{l}\text { Lf } \\
B d \\
\mathrm{Bd} \\
\end{array}$ & $\begin{array}{l}7+ \\
6+ \\
3+ \\
\end{array}$ & $\begin{array}{l}5+ \\
3+ \\
2+ \\
\end{array}$ & * & $\begin{array}{l}\text { no } \\
\text { no } \\
\text { no }\end{array}$ & $\begin{array}{l}10 \\
10 \\
10 \\
\end{array}$ & $\begin{array}{l}10 \\
10 \\
10 \\
\end{array}$ & $\begin{array}{r}57 \\
0 \\
0 \\
\end{array}$ & $\begin{array}{r}7+ \\
\vdots \\
1+ \\
\end{array}$ & $\begin{array}{c}1+ \\
3+ \\
-5 \\
\end{array}$ \\
\hline $\begin{array}{l}\text { Sweaters (zipless). RN wool ly-pully } \\
\text { Private varlous }\end{array}$ & $D f$ & -5 & $\begin{array}{l}-6 \\
2+\end{array}$ & & $\begin{array}{l}\text { no } \\
\text { no } \\
\end{array}$ & $\begin{array}{r}20 \\
0 \\
\end{array}$ & $\begin{array}{r}20 \\
6 \\
\end{array}$ & $\begin{array}{l}40 \\
20 \\
\end{array}$ & $\begin{array}{c}-7 \\
1+ \\
\end{array}$ & $\begin{array}{l}-9 \\
-1 \\
\end{array}$ \\
\hline $\begin{array}{l}\text { Inner jacketsofibrepile, various } \\
\text { Thermofleece jacket } \\
\text { Thermotex waistoat } \\
\text { Service Hochiminh quilted jacket } \\
\text { Trlals Hochiminh thinsulate Jacket } \\
\text { Dacron-fill led "duvet" jackets } \\
\text { Down duvet jackets, var lous } \\
\end{array}$ & $\begin{array}{ll}M e & M e \\
S a & S a \\
& L f \\
& S i \\
& R a\end{array}$ & 6+: & $\begin{array}{l}8+ \\
7+ \\
5+ \\
3+ \\
\end{array}$ & & $\begin{array}{l}\text { no } \\
\text { no } \\
\text { no } \\
\text { no } \\
\text { no } \\
\text { no } \\
\text { no } \\
\end{array}$ & $\begin{array}{r}3 \\
0 \\
0 \\
11 \\
12 \\
0 \\
0 \\
0\end{array}$ & $\begin{array}{r}7 \\
0 \\
0 \\
12 \\
12 \\
10 \\
2 \\
2\end{array}$ & $\begin{array}{r}8 \\
17 \\
4 \\
0 \\
0 \\
0 \\
3 \\
\end{array}$ & $\begin{array}{c}\vdots \\
\vdots \\
-7 \\
-2 \\
\vdots \\
\vdots\end{array}$ & $\begin{array}{c}6+ \\
\vdots \\
\vdots \\
-2 \\
1+ \\
\vdots \\
5+ \\
+\end{array}$ \\
\hline 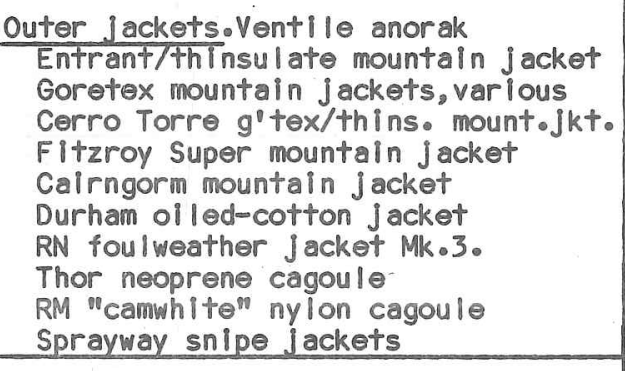 & $\begin{array}{ll}\text { Ib } & S i \\
\text { Si } \\
M e & M e \\
M e & M e \\
\text { Ib } & 1 b \\
B a & B a \\
B b & D f \\
B b & B b \\
& C f \\
\end{array}$ & $\begin{array}{l}1+ \\
-2\end{array}$ & $\begin{array}{l}7+ \\
1+ \\
3+ \\
1+\end{array}$ & $\begin{array}{l}* \\
* \\
* \\
* \\
* \\
* \\
* \\
* \\
* \\
*\end{array}$ & $\begin{array}{l}\text { no } \\
\text { no } \\
\text { no } \\
\text { no } \\
\text { no } \\
\text { no } \\
\text { no } \\
\text { no } \\
\text { no } \\
\text { no } \\
\text { no } \\
\end{array}$ & $\begin{array}{c}2 \\
8+ \\
1 \\
0 \\
0 \\
0 \\
1 \\
2+ \\
10 \\
0 \\
0 \\
\end{array}$ & $\begin{array}{r}0 \\
3 \\
3 \\
10 \\
2 \\
0 \\
0 \\
0 \\
10 \\
5 \\
0 \\
\end{array}$ & \begin{tabular}{r|}
0 \\
0 \\
3 \\
0 \\
0 \\
17 \\
9 \\
20 \\
0 \\
0 \\
0 \\
1 \\
\end{tabular} & $\begin{array}{c}\vdots \\
\vdots \\
\vdots \\
\vdots \\
\vdots \\
\vdots\end{array}$ & $\begin{array}{c}\vdots \\
5+ \\
1+ \\
-6 \\
1+ \\
\vdots \\
\vdots \\
1+ \\
-7 \\
8+ \\
\vdots \\
\end{array}$ \\
\hline $\begin{array}{l}\text { Trousers, ventlle trousers } \\
\text { Canadian army cotton trousers } \\
\text { Salopettes } \\
\text { Breeches } \\
\text { Breaches } \\
\text { RN foulweather trousers } \\
\text { Thor nooprene overtrousers } \\
\text { Entrant overtrousers } \\
\text { Goretex overtrousers, private } \\
\text { Mica overtrousers } \\
\text { Strata overtrousers } \\
\text { Service Hochiminh gullted inners } \\
\end{array}$ & 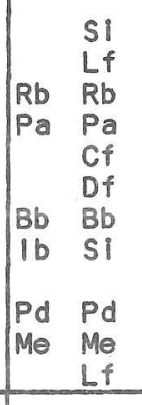 & $\begin{array}{c}5+ \\
\vdots \\
\vdots \\
-1\end{array}$ & $\begin{array}{c}-1 \\
6+ \\
2+ \\
3+ \\
\vdots \\
1+ \\
\vdots \\
1+\end{array}$ & $\begin{array}{l}* \\
* \\
* \\
* \\
* \\
* \\
*\end{array}$ & $\begin{array}{l}\mathrm{pr} \\
\mathrm{pr} \\
\mathrm{pr} \\
\mathrm{pr} \\
\mathrm{pr} \\
\mathrm{pr} \\
\mathrm{pr} \\
\mathrm{pr} \\
\mathrm{pr} \\
\mathrm{pr} \\
\mathrm{pr} \\
\mathrm{pr}\end{array}$ & $\begin{array}{c}3+ \\
30 \\
0 \\
10 \\
0 \\
2+ \\
20 \\
4+ \\
4 \\
0 \\
0 \\
0 \\
11\end{array}$ & $\begin{array}{r}0 \\
20 \\
5 \\
12 \\
0 \\
0 \\
0 \\
12 \\
6 \\
1 \\
1 \\
0 \\
0 \\
12 \\
\end{array}$ & $\begin{array}{r}0 \\
0 \\
16 \\
0 \\
16 \\
0 \\
1 \\
0 \\
0 \\
0 \\
10 \\
6 \\
0 \\
\end{array}$ & $\begin{array}{c}\vdots \\
-7 \\
\vdots \\
\vdots \\
\vdots \\
\vdots \\
\vdots\end{array}$ & $\begin{array}{c}1+ \\
1+ \\
3+ \\
2+ \\
\vdots \\
1+ \\
\vdots+ \\
3+ \\
3+ \\
\vdots \\
\vdots \\
2+\end{array}$ \\
\hline 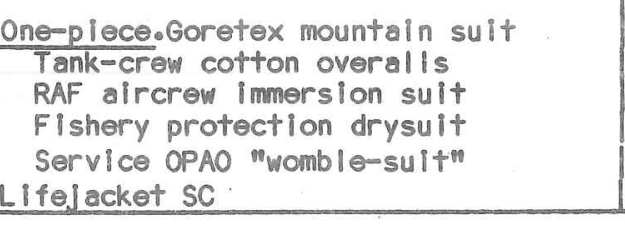 & $\begin{array}{ll} & S i \\
& \mathrm{Lf} \\
& \mathrm{Rd} \\
\mathrm{Mg} & \mathrm{Mg} \\
\mathrm{Of} \\
\mathrm{Of} \\
\mathrm{Ph} \\
\end{array}$ & {$\left[\begin{array}{c}\vdots \\
-2 \\
2+ \\
7+\end{array}\right.$} & $\begin{array}{r}5+ \\
6+ \\
5+ \\
1+ \\
\vdots \\
4+ \\
\end{array}$ & * & $\begin{array}{l}\text { pr } \\
\text { no } \\
\text { no } \\
\text { no } \\
\text { no } \\
\text { no } \\
\end{array}$ & $\begin{array}{l}0 \\
10 \\
10+ \\
10+ \\
10+ \\
10+ \\
\end{array}$ & $\begin{array}{c}1 \\
12 \\
10 \\
0 \\
0 \\
0 \\
\end{array}$ & $\begin{array}{c}0 \\
0 \\
16 \\
0 \\
0\end{array}$ & $\begin{array}{l}\vdots \\
-7 \\
-7 \\
\vdots\end{array}$ & $\begin{array}{l}7+ \\
2+ \\
1+ \\
3+ \\
-3 \\
2+\end{array}$ \\
\hline
\end{tabular}


102

\begin{tabular}{|c|c|c|c|c|c|c|c|c|c|c|}
\hline \multirow{3}{*}{ ITEM } & 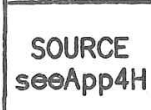 & \multirow{2}{*}{\multicolumn{2}{|c|}{$\begin{aligned} \text { QUALITY } \\
\text { VOTES } \\
\text { Excellent } \\
\text { : Satisfact } \\
- \text { Poor } \\
\end{aligned}$}} & \multirow{3}{*}{$\begin{array}{l}R \\
e \\
P \\
P\end{array}$} & \multicolumn{4}{|c|}{ QUANTITY TAKEN } & \multirow{2}{*}{\multicolumn{2}{|c|}{$\begin{aligned} & \text { QUANTITY } \\
& \text { VOTES } \\
&+ \text { More needed } \\
&: \text { Adequate } \\
&- \text { Too much }\end{aligned}$}} \\
\hline & \multirow{2}{*}{$\begin{array}{ll}M & S \\
a & u \\
k & p \\
\ominus & p\end{array}$} & & & & \multirow{2}{*}{\begin{tabular}{|l|}
$D$ \\
$E$ \\
$N$ \\
$D$ \\
$M$
\end{tabular}} & \multirow{2}{*}{\begin{tabular}{l|}
15 \\
10 \\
men
\end{tabular}} & \multirow{2}{*}{$\begin{array}{l}\text { OW } \\
12 \\
\text { men }\end{array}$} & \multirow{2}{*}{\begin{tabular}{|l|}
25 \\
17 \\
men
\end{tabular}} & & \\
\hline & & \begin{tabular}{|l|} 
is \\
$\max 7$
\end{tabular} & $\underset{\max 10}{\mathrm{ow}}$ & & & & & & $\begin{array}{l}15 \\
\max 7\end{array}$ & OW 10 \\
\hline 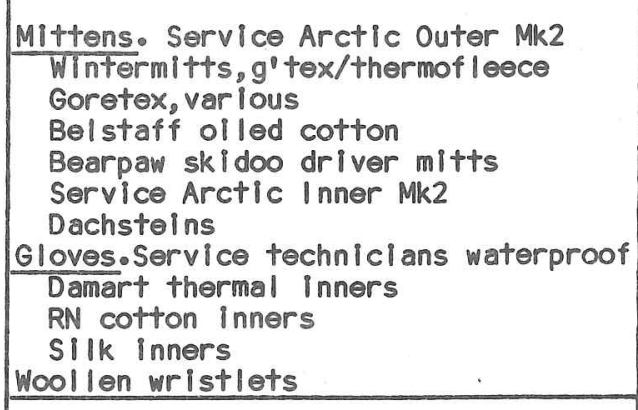 & $\begin{array}{ll}\text { Wd } & \mathrm{Lf} \\
\mathrm{Si} \\
\\
\mathrm{Cg} \\
\mathrm{Cg} \\
\mathrm{Lf} \\
\mathrm{Lf} \\
\mathrm{Lf} \\
\mathrm{He} \\
\mathrm{Ph} \\
\mathrm{Ph} \\
\mathrm{Lf} \\
\end{array}$ & $\begin{array}{c}7+ \\
2+ \\
-7 \\
2+ \\
\vdots \\
7+\end{array}$ & $\begin{array}{c}8+ \\
-10 \\
2+ \\
3+ \\
2+ \\
4+ \\
7+ \\
-1 \\
8+ \\
3+ \\
8 \\
8+ \\
\end{array}$ & $\begin{array}{l}* \\
*\end{array}$ & $\begin{array}{l}\mathrm{pr} \\
\mathrm{pr} \\
\mathrm{pr} \\
\mathrm{pr} \\
\mathrm{pr} \\
\mathrm{pr} \\
\mathrm{pr} \\
\mathrm{pr} \\
\mathrm{pr} \\
\mathrm{pr} \\
\mathrm{pr} \\
\mathrm{pr}\end{array}$ & $\begin{array}{c}20 \\
11 \\
0 \\
0 \\
0 \\
20 \\
10 \\
4+ \\
5 \\
0 \\
16 \\
10 \\
\end{array}$ & $\begin{array}{r}20 \\
12 \\
2 \\
1 \\
4 \\
20 \\
12 \\
0+ \\
10 \\
1 \\
32 \\
12\end{array}$ & $\begin{array}{r}0 \\
0 \\
0 \\
0 \\
0 \\
0 \\
32 \\
0 \\
0 \\
80 \\
0 \\
20\end{array}$ & $\begin{array}{l}\vdots \\
-7 \\
\vdots \\
\vdots \\
\vdots \\
-3 \\
-7 \\
\vdots \\
\vdots\end{array}$ & $\begin{array}{c}4+ \\
\vdots \\
3+ \\
3+ \\
\vdots \\
4+ \\
4+ \\
1+ \\
9+ \\
3+ \\
2+ \\
7+\end{array}$ \\
\hline 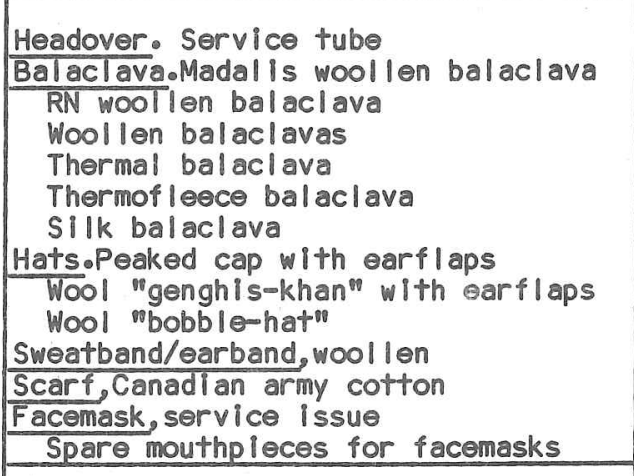 & $\begin{array}{ll} & L f \\
D b & D b \\
S I & D f \\
S I & S 1 \\
M e & M C \\
M e & M e\end{array}$ & $\begin{array}{c}7+ \\
\vdots \\
:\end{array}$ & \begin{tabular}{c|c}
$8+$ \\
$\vdots$ \\
-6 \\
$\vdots$ \\
$\vdots$ \\
$1+$ \\
$4+$ \\
$3+$ \\
$1+$ \\
$7+$ \\
$3+$ \\
$6+$ \\
$4+$ \\
\end{tabular} & * & $\begin{array}{l}\text { no } \\
\text { no } \\
\text { no } \\
\text { no } \\
\text { no } \\
\text { no } \\
\text { no } \\
\text { no } \\
\text { no } \\
\text { no } \\
\text { no } \\
\text { no } \\
\text { no } \\
\text { no }\end{array}$ & $\begin{array}{r}10 \\
5 \\
10 \\
2 \\
10 \\
0 \\
0 \\
0 \\
7 \\
0 \\
2 \\
10 \\
0 \\
0 \\
\end{array}$ & $\begin{array}{r}12 \\
10 \\
12 \\
12 \\
10 \\
0 \\
3 \\
2 \\
7 \\
16 \\
6 \\
10 \\
12 \\
36 \\
\end{array}$ & \begin{tabular}{r|}
20 \\
0 \\
1 \\
0 \\
0 \\
17 \\
0 \\
0 \\
0 \\
17 \\
0 \\
0 \\
0 \\
0 \\
\end{tabular} & $\begin{array}{c}\vdots \\
5+ \\
\vdots \\
\vdots \\
\vdots \\
\vdots \\
\vdots \\
\vdots\end{array}$ & $\begin{array}{c}6+ \\
2+ \\
-5 \\
-3 \\
1+ \\
\vdots \\
\vdots \\
3+ \\
2+ \\
-3 \\
4+ \\
2+ \\
5+ \\
\vdots\end{array}$ \\
\hline $\begin{array}{l}\text { Goggles.Uvex ski-goggles (visor) } \\
\text { Alrcrew MkJ visors goggles } \\
\text { Private visor type ski-goggles } \\
\text { Service plastic "bra" type goggles } \\
\text { RM Arctic meshframe folding goggles } \\
\text { "Goggles 30 } \\
\text { Sunglasses.Glacier glasses } \\
\text { Polarold specs } \\
\text { Other sunglasses } \\
\end{array}$ & 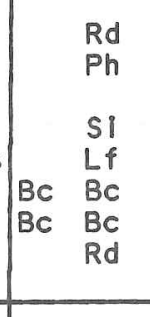 & $\begin{array}{l}-7 \\
: \\
\dot{1} \\
1+\end{array}$ & $\begin{array}{l}-2 \\
1+ \\
-6 \\
5+\end{array}$ & & $\begin{array}{l}\mathrm{pr} \\
\mathrm{pr} \\
\mathrm{pr} \\
\mathrm{pr} \\
\mathrm{pr} \\
\mathrm{pr} \\
\mathrm{pr} \\
\mathrm{pr} \\
\mathrm{pr}\end{array}$ & $\begin{array}{r}8 \\
10 \\
0 \\
10 \\
10 \\
0 \\
0 \\
8 \\
0 \\
0\end{array}$ & $\begin{array}{r}8 \\
0 \\
5 \\
12 \\
12 \\
0 \\
0 \\
12 \\
5 \\
\end{array}$ & $\begin{array}{r}0 \\
0 \\
0 \\
0 \\
0 \\
18 \\
19 \\
0 \\
0 \\
\end{array}$ & $\begin{array}{c}-7 \\
-7 \\
\vdots \\
\vdots \\
\vdots \\
\end{array}$ & $\begin{array}{c}-1 \\
\vdots \\
1+ \\
-8 \\
1+ \\
\vdots \\
\vdots \\
2+ \\
5+\end{array}$ \\
\hline 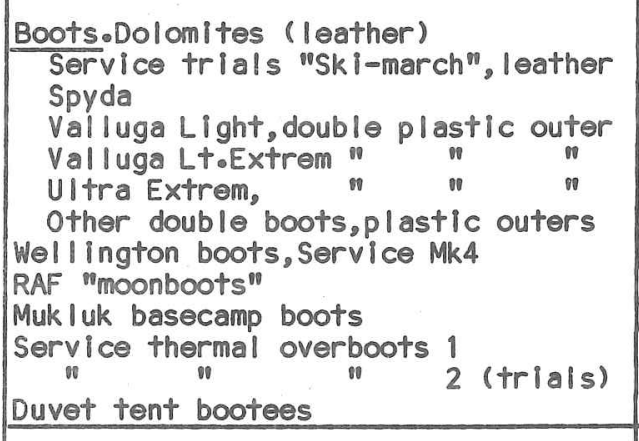 & \begin{tabular}{|ll} 
& $R d$ \\
& $R i$ \\
& $S i$ \\
$K c$ & $B b$ \\
$K c$ & $V a$ \\
$K c$ & $V a$ \\
$K c$ & \\
& \\
& $P h$ \\
& $R d$ \\
$M f$ & $M f$ \\
& Lf \\
& $S i$ \\
& $L f$ \\
\end{tabular} & -7 & $\begin{array}{c}-7 \\
2+ \\
3+ \\
: \\
7+ \\
2+ \\
4+ \\
8+ \\
\end{array}$ & $\begin{array}{l}* \\
* \\
* \\
*\end{array}$ & $\begin{array}{l}\mathrm{pr} \\
\mathrm{pr} \\
\mathrm{pr} \\
\mathrm{pr} \\
\mathrm{pr} \\
\mathrm{pr} \\
\mathrm{pr} \\
\mathrm{pr} \\
\mathrm{pr} \\
\mathrm{pr} \\
\mathrm{pr} \\
\mathrm{pr} \\
\mathrm{pr}\end{array}$ & $\begin{array}{c}10 \\
0 \\
0 \\
10 \\
0 \\
0 \\
0 \\
0 \\
10+ \\
0 \\
0 \\
0 \\
0 \\
0 \\
\end{array}$ & $\begin{array}{r}12 \\
12 \\
0 \\
0 \\
10 \\
1 \\
3 \\
0 \\
0+ \\
0 \\
1 \\
10 \\
4 \\
10 \\
\end{array}$ & $\begin{array}{r}17 \\
0 \\
13 \\
0 \\
0 \\
7 \\
0 \\
0 \\
10 \\
6 \\
0 \\
0 \\
0 \\
\end{array}$ & $\begin{array}{c}\vdots \\
\vdots \\
\vdots \\
\vdots \\
\vdots \\
\vdots \\
\vdots \\
\vdots\end{array}$ & $\begin{array}{c}-1 \\
-3 \\
\vdots \\
\vdots \\
\vdots \\
5+ \\
3+ \\
\vdots \\
9+ \\
1+ \\
6+ \\
1+ \\
\end{array}$ \\
\hline $\begin{array}{l}\text { Snowgaiters. Service Arctic Mk2 } \\
\text { Downhill ski gaiters } \\
\text { SuperYeti gaiters } \\
\text { Standard Yet i gaiters } \\
\text { Spare rands for yetl gaiters } \\
\end{array}$ & \begin{tabular}{|ll} 
& $\mathrm{Lf}$ \\
$\mathrm{Bb}$ & $\mathrm{Bb}$ \\
$\mathrm{Bb}$ & $\mathrm{Bb}$ \\
$\mathrm{Bb}$ & $\mathrm{Bb}$ \\
$\mathrm{Bb}$ & $\mathrm{Bb}$ \\
\end{tabular} & $\begin{array}{l}1+ \\
-5 \\
5+\end{array}$ & $\begin{array}{l}2+ \\
-1 \\
9+ \\
1+\end{array}$ & * & $\begin{array}{l}\mathrm{pr} \\
\mathrm{pr} \\
\mathrm{pr} \\
\mathrm{pr} \\
\mathrm{pr}\end{array}$ & $\begin{array}{l}16 \\
30 \\
10 \\
0 \\
10+ \\
\end{array}$ & $\begin{array}{r}24 \\
40 \\
12 \\
0 \\
0 \\
\end{array}$ & $\begin{array}{c}0 \\
0 \\
0 \\
20 \\
0 \\
0\end{array}$ & $\begin{array}{c}\vdots \\
\vdots \\
2+ \\
\vdots \\
\end{array}$ & $\begin{array}{c}-1 \\
-1 \\
6+ \\
\vdots \\
-1 \\
\end{array}$ \\
\hline
\end{tabular}

E:

\begin{tabular}{|c|c|c|c|c|c|c|c|c|c|c|c|}
\hline \multirow{4}{*}{ ITEM } & \multicolumn{5}{|c|}{ DOMESTIC GEAR. } & & & & & & \\
\hline & \multicolumn{2}{|c|}{$\begin{array}{c}\text { SOURCE } \\
\text { seeApp } 4 \text {. }\end{array}$} & \multirow{2}{*}{\multicolumn{2}{|c|}{$\begin{array}{l}\text { QUAL ITY } \\
\text { VOTES } \\
+ \text { Excell lent } \\
\vdots \text { Satisfact } \\
- \text { Poor }\end{array}$}} & \multirow{3}{*}{$\begin{array}{ll}R \\
G \\
S \\
R \\
R \\
P \\
P \\
r \\
+\end{array}$} & \multicolumn{4}{|c|}{ QUANTITY TAKEN } & \multirow{2}{*}{\multicolumn{2}{|c|}{$\begin{aligned} & \text { QUANTITY } \\
& \text { VOTES } \\
&+ \text { More needed } \\
&: \text { Adequate } \\
&- \text { Too much }\end{aligned}$}} \\
\hline & & \multirow{2}{*}{$\begin{array}{l}s \\
u \\
p \\
p\end{array}$} & & & & \multirow{2}{*}{$\begin{array}{l}D \\
E \\
N \\
O \\
M\end{array}$} & \multirow{2}{*}{$\begin{array}{l}15 \\
10 \\
\text { men }\end{array}$} & \multirow{2}{*}{$\begin{array}{l}\text { OW } \\
12 \\
\text { men }\end{array} \mid$} & \multirow{2}{*}{$\begin{array}{l}25 \\
17 \\
\text { men }\end{array}$} & & \\
\hline & & & \begin{tabular}{|l|}
15 \\
$\max 7$
\end{tabular} & OW & & & & & & $\begin{array}{l}15 \\
\max 7\end{array}$ & OW \\
\hline 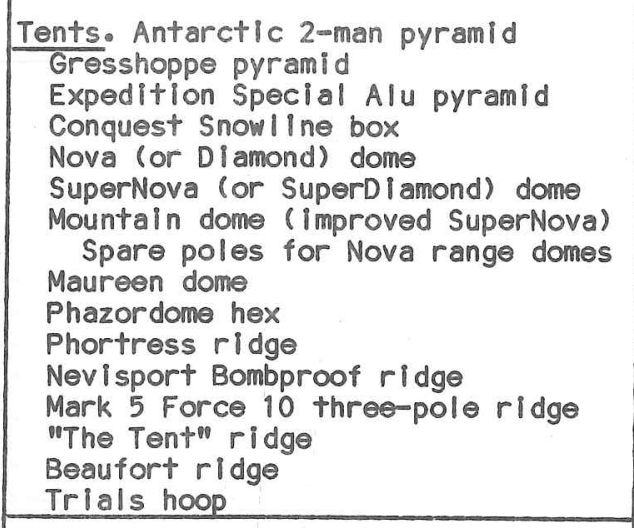 & & $\begin{array}{ll}b & M b \\
& \mathrm{Cd} \\
\mathrm{C} & \mathrm{Fb} \\
\mathrm{d} & \mathrm{Td} \\
\mathrm{d} & \mathrm{SI} \\
\mathrm{d} & \mathrm{Wb} \\
\mathrm{d} & \mathrm{Wb} \\
\mathrm{d} & \mathrm{Wb} \\
\mathrm{Ha} \\
\mathrm{Ha} \\
\mathrm{Ha} \\
\mathrm{d} \\
\mathrm{Cd} \\
\mathrm{Pd} \\
\mathrm{Nd} \\
\mathrm{Na} \\
\mathrm{Va} \\
\mathrm{Va} \\
\mathrm{Va} \\
\mathrm{Va} \\
\end{array}$ & $\begin{array}{c}7+ \\
\vdots \\
-1 \\
\vdots \\
\vdots \\
-5 \\
\vdots \\
4+ \\
\vdots \\
\vdots \\
-2 \\
\end{array}$ & $\begin{array}{c}9+ \\
1+ \\
-9 \\
2+ \\
-2 \\
1+ \\
-7 \\
\vdots \\
1+ \\
2+ \\
: \\
-3 \\
-6 \\
\end{array}$ & 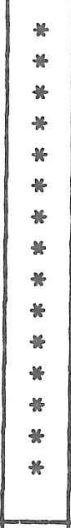 & $\begin{array}{l}\text { no } \\
\text { no } \\
\text { no } \\
\text { no } \\
\text { no } \\
\text { no } \\
\text { no } \\
\text { sets } \\
\text { no } \\
\text { no } \\
\text { no } \\
\text { no } \\
\text { no } \\
\text { no } \\
\text { no } \\
\text { no }\end{array}$ & $\begin{array}{l}5+ \\
2+ \\
2+ \\
3+ \\
4+ \\
6+ \\
1+ \\
0 \\
6+ \\
0 \\
0 \\
7+ \\
1+ \\
3+ \\
0 \\
2+ \\
0\end{array}$ & $\begin{aligned} &+ 0+ \\
&+ 0+ \\
&+ 0 \\
& 0+ \\
&+ \\
& 0+ \\
&+12+ \\
& 0 \\
&+7 \\
& 1 \\
& 1 \\
& 0 \\
& 0+ \\
& 0+ \\
& 0+ \\
& 0+ \\
& 0 \\
& 0 \\
& 1\end{aligned}$ & $\begin{array}{l}0 \\
0 \\
0 \\
0 \\
0 \\
2 \\
4 \\
0 \\
0 \\
0 \\
6 \\
0 \\
0 \\
0 \\
48 \\
0 \\
0\end{array}$ & $\begin{array}{c}\vdots \\
\vdots \\
\vdots \\
\vdots \\
\vdots+ \\
\vdots \\
\vdots+ \\
\vdots \\
\vdots \\
\vdots \\
\vdots\end{array}$ & $\begin{array}{c}7+ \\
\vdots \\
-9 \\
-1 \\
1+ \\
6+ \\
\vdots \\
\vdots 0+ \\
\vdots \\
\vdots \\
-1 \\
-2 \\
1+ \\
\vdots \\
-4 \\
-3\end{array}$ \\
\hline $\begin{array}{l}\text { Closed cell mats. } 12 \mathrm{~mm} \text { sleeping mat } \\
\text { Thermorest sleoping mat } \\
4 \text { minn rolls for basecamp }\end{array}$ & & $\begin{array}{r}L f \\
3 \\
M C \\
\end{array}$ & $\begin{array}{l}7+ \\
7+ \\
\end{array}$ & $\begin{array}{c}1+ \\
-1 \\
\end{array}$ & $*$ & $\begin{array}{c}\text { no } \\
\text { no } \\
\text { roll }\end{array}$ & & & & $\begin{array}{r}\vdots \\
\vdots \\
7+ \\
\end{array}$ & $\begin{array}{c}6+ \\
\vdots \\
\end{array}$ \\
\hline $\begin{array}{l}\text { Sleoping bag.Service trials superloft } \\
\text { Gold Phlash } \\
\text { Caravan Thor } \\
\text { Firebird } \\
\text { Polywarm Basecamp hollofil } \\
\text { Dolonite } \\
\text { Buffalo fibrepile } \\
\text { Bivouac bag.service goretex } \\
\text { Tyvek (paper) } \\
\end{array}$ & & $\begin{array}{l}S 1 \\
P d \\
M C \\
M C \\
M g \\
P G \\
M c \\
\text { Sk } \\
\text { Si } \\
\quad \\
\end{array}$ & $\begin{array}{c}5+ \\
\vdots \\
1+ \\
1+ \\
5+ \\
5+ \\
1+\end{array}$ & $\begin{array}{c}-4 \\
\vdots \\
-2 \\
1+ \\
2+ \\
-1 \\
8+ \\
5+ \\
\end{array}$ & $\begin{array}{l}* \\
* \\
* \\
* \\
* \\
\end{array}$ & $\begin{array}{l}\text { no } \\
\text { no } \\
\text { no } \\
\text { no } \\
\text { no } \\
\text { no } \\
\text { no } \\
\text { no } \\
\text { no } \\
\end{array}$ & $\begin{array}{c}10 \\
0 \\
6 \\
1 \\
1+ \\
0 \\
0 \\
10 \\
1+\end{array}$ & $\begin{array}{r}12 \\
10 \\
1 \\
0 \\
0 \\
2 \\
2 \\
2 \\
12 \\
1 \\
\end{array}$ & $\begin{array}{r}0 \\
0 \\
0 \\
20 \\
0 \\
0 \\
0 \\
16 \\
0 \\
\end{array}$ & $\begin{array}{c}\vdots \\
\vdots \\
\vdots \\
\vdots \\
\vdots \\
7+ \\
\vdots \\
\end{array}$ & $\begin{array}{c}1+ \\
\vdots \\
-1 \\
\vdots \\
2+ \\
4+ \\
-2 \\
7+ \\
9+ \\
\end{array}$ \\
\hline $\begin{array}{l}\text { Stoves. Optimus } 111.8 \text { parafin stove } \\
\text { Optimus } 111 . T \text { multi-fuel stove } \\
\text { Spare burners for stoves } \\
\text { Spares } k \text { its for stoves } \\
\text { MSR multifuel stove } \\
\end{array}$ & & $\begin{array}{l}\mathrm{Ph} \\
0 \mathrm{a} \\
0 \mathrm{a} \\
\mathrm{Oa}\end{array}$ & $\begin{array}{c}2+ \\
4+ \\
\vdots \\
7+\end{array}$ & $\begin{array}{c}9+ \\
6+ \\
\vdots \\
2+\end{array}$ & $\begin{array}{l}* \\
* \\
* \\
*\end{array}$ & $\begin{array}{c}\text { no } \\
\text { no } \\
\text { no } \\
\text { kits } \\
\text { no }\end{array}$ & $\begin{array}{l}8+ \\
2+ \\
2+ \\
4+ \\
0\end{array}$ & $\begin{array}{l}0+ \\
4+ \\
0+ \\
6+ \\
0\end{array}$ & $\begin{array}{r}0 \\
4 \\
0 \\
10 \\
0 \\
\end{array}$ & $\begin{array}{r}\vdots \\
\vdots \\
\vdots+ \\
7+ \\
\end{array}$ & $\begin{array}{r}5+ \\
4+ \\
9+ \\
10+ \\
5+ \\
\end{array}$ \\
\hline $\begin{array}{l}\text { Cooking gear.Messtins } \\
\text { 3-plece nesting set of pots + Iids } \\
\text { Folding ovens } \\
\text { Pressure cooker } \\
4-p \text { int kettle } \\
\text { 8-pint pot } \\
7-i n c h \text { knife } \\
\text { Table spoon } \\
\text { Plier-type tin openers } \\
\end{array}$ & & $\begin{array}{l}\text { Ph } \\
\text { Lf } \\
P h \\
P h \\
P h \\
P h \\
P h \\
P h \\
P h\end{array}$ & $\begin{array}{c}7+ \\
\vdots \\
7+ \\
7+ \\
\vdots \\
\vdots \\
\end{array}$ & $\begin{array}{c}1+ \\
6+ \\
-1 \\
\vdots \\
\vdots \\
5+ \\
\vdots \\
-4 \\
\end{array}$ & & \begin{tabular}{|l} 
pr \\
sets \\
no \\
no \\
no \\
no \\
no \\
no \\
no \\
\end{tabular} & $\begin{aligned} 12+ \\
6+ \\
0+ \\
2+ \\
2+ \\
2+ \\
4+ \\
4+ \\
8+ \\
\end{aligned}$ & $\begin{aligned}+12+ \\
1 \\
1+ \\
2+ \\
0+ \\
0+ \\
0+ \\
0+ \\
0+ \\
0+ \\
0+\end{aligned}$ & $\begin{array}{l}0 \\
6 \\
0 \\
0 \\
0 \\
1 \\
4 \\
2 \\
0 \\
\end{array}$ & $\begin{array}{c}7+ \\
-7 \\
\vdots \\
7+ \\
\vdots \\
\vdots \\
\vdots\end{array}$ & $\begin{array}{c}-4 \\
4+ \\
-4 \\
-1 \\
-5 \\
\vdots \\
1+ \\
-5 \\
-5 \\
-5\end{array}$ \\
\hline 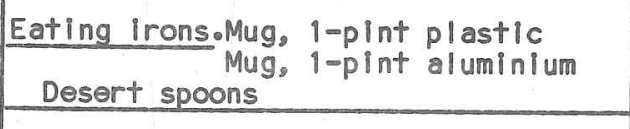 & & $\begin{array}{l}\mathrm{Ph} \\
\mathrm{Lf} \\
\mathrm{Ph}\end{array}$ & $\begin{array}{l}7+ \\
5+ \\
7+ \\
\end{array}$ & $\begin{array}{c}-1 \\
6+ \\
\vdots\end{array}$ & & $\begin{array}{l}\text { no } \\
\text { no } \\
\text { no. }\end{array}$ & $\begin{array}{l}12 \\
12 \\
20 \\
\end{array}$ & $\begin{array}{r}1 \\
14 \\
30 \\
\end{array}$ & $\begin{array}{r}16 \\
0 \\
40 \\
\end{array}$ & $\begin{aligned} 1+ \\
\vdots \\
\end{aligned}$ & $\stackrel{8}{4+}$ \\
\hline $\begin{array}{l}\text { Thermosflask o1 pto steel unbreakable } \\
\text { Standard T-pint flask } \\
\text { Insulating foam flask carrier } \\
\end{array}$ & & $\begin{array}{l}\mathrm{Lf} \\
\mathrm{Ph} \\
\mathrm{Lf} \\
\end{array}$ & & & & $\begin{array}{l}\text { no } \\
\text { no } \\
\text { no }\end{array}$ & $\begin{array}{r}10 \\
0 \\
10 \\
\end{array}$ & $\begin{array}{r}12 \\
0 \\
12 \\
\end{array}$ & $\begin{array}{l}16 \\
16 \\
16 \\
\end{array}$ & $\vdots$ & $\begin{array}{c}1+ \\
\vdots \\
-6 \\
\end{array}$ \\
\hline $\begin{array}{l}\text { Plastic screwtop poebottle } \\
\text { Pnowbrush ("brush sink snow") } \\
\text { Sponge } \\
\text { Scotchbrite plastic scouring pads } \\
\text { Kimwlpe paper towels } \\
\text { Naillbrushes } \\
\text { Detergent } \\
\text { Washing powder } \\
\text { Soap }\end{array}$ & & $\begin{array}{l}\mathrm{Ph} \\
\mathrm{Ph} \\
\mathrm{Ph} \\
\mathrm{Ph} \\
\mathrm{Ph}\end{array}$ & $\begin{array}{c}7+ \\
7+ \\
7+ \\
\vdots \\
\vdots \\
\vdots \\
\end{array}$ & $\begin{array}{c}6+ \\
6+ \\
1+ \\
1+ \\
3+ \\
\vdots \\
\vdots \\
\vdots\end{array}$ & & $\begin{array}{l}\text { no } \\
\text { no } \\
\text { no } \\
\text { hits } \\
\text { roll } \\
\text { no } \\
\text { bott } \\
\text { box } \\
\text { bars } \\
\text { bars }\end{array}$ & $\begin{array}{r}0 \\
10+ \\
16+ \\
40 \\
50 \\
8+ \\
2+ \\
2+ \\
24+\end{array}$ & $\begin{array}{r}+8+ \\
+32+ \\
100 \\
90 \\
+\quad 0+ \\
+\quad 2+\end{array}$ & $\begin{array}{r}0 \\
20 \\
10 \\
10 \\
0 \\
2 \\
0\end{array}$ & $\begin{array}{r}\vdots \\
\vdots \\
\vdots \\
\vdots \\
\vdots \\
4+ \\
4+ \\
\end{array}$ & $\begin{array}{c}4+ \\
6+ \\
-5 \\
\vdots \\
1+ \\
-3 \\
-5 \\
-7 \\
-8 \\
\end{array}$ \\
\hline
\end{tabular}


104

\begin{tabular}{|c|c|c|c|c|c|c|c|c|c|c|}
\hline \multirow{4}{*}{ ITEM } & \multirow{2}{*}{$\begin{array}{l}\text { SOURCE } \\
\text { se®APp4H }\end{array}$} & \multirow{3}{*}{\multicolumn{2}{|c|}{$\begin{array}{l}\text { QUALITY } \\
\text { VOTES } \\
+ \text { Excellent } \\
\text { : Satisfact } \\
- \text { Poor } \\
\end{array}$}} & \multirow{4}{*}{$\begin{array}{l}R \\
G \\
S \\
R \\
R \\
\theta \\
P \\
0 \\
r \\
+ \\
\end{array}$} & \multirow{2}{*}{\multicolumn{4}{|c|}{ QUANTITY TAKEN }} & \multirow{3}{*}{\multicolumn{2}{|c|}{$\begin{array}{l}\text { QUANTITY } \\
\text { VOTES } \\
\text { More needed } \\
\text { Adequate } \\
\text { Too much } \\
\end{array}$}} \\
\hline & & & & & & & & & & \\
\hline & \multirow{2}{*}{$\begin{array}{ll}M & s \\
a & u \\
k & p \\
\theta & p\end{array}$} & & & & \multirow{2}{*}{\begin{tabular}{|l}
$D$ \\
$E$ \\
$N$ \\
$N$ \\
$D$ \\
$M$
\end{tabular}} & \multirow{2}{*}{$\begin{array}{l}15 \\
10 \\
\text { men }\end{array}$} & \multirow{2}{*}{$\begin{array}{l}\text { OW } \\
12 \\
\text { men }\end{array}$} & \multirow{2}{*}{\begin{tabular}{|l|}
$2 S$ \\
17 \\
men
\end{tabular}} & & \\
\hline & & \begin{tabular}{|l|}
15 \\
$\max 7$ \\
\end{tabular} & $\underset{\max 10}{\mathrm{O}}$ & & & & & & $\begin{array}{l}15 \\
\max 7\end{array}$ & OW 10 \\
\hline $\begin{array}{c}\text { Stores boxes.Plycases, size F } \\
\text { Plycases, size H } \\
\text { Plycases, size J } \\
\text { Plycases, size K } \\
\text { Triwall cardboard boxes, var lous } \\
\text { Wooden hinge-top "kop" boxes } \\
\text { Alloy boxes } \\
\text { Milat hinge-top ammunition boxes } \\
\text { Alr-portable "rThomas" boxes } \\
\text { Watertight plastic barrels } \\
\text { n screwtop Schermully bottles } \\
\text { n plastic boxes } \\
\end{array}$ & $\begin{array}{ll} & \mathrm{He} \\
\mathrm{Bf} & \mathrm{Bf} \\
\mathrm{La} & \mathrm{La} \\
\end{array}$ & $\begin{array}{c}\vdots \\
\vdots \\
\vdots \\
\vdots \\
4+ \\
\vdots\end{array}$ & $\begin{array}{l}\vdots \\
2+ \\
7+ \\
1+ \\
1+ \\
6+ \\
5+\end{array}$ & & $\begin{array}{l}\text { no } \\
\text { no } \\
\text { no } \\
\text { no } \\
\text { no } \\
\text { no } \\
\text { no } \\
\text { no } \\
\text { no } \\
\text { no } \\
\text { no } \\
\text { no } \\
\end{array}$ & $\begin{aligned} 50+ \\
130+ \\
30+ \\
10+ \\
0 \\
4+ \\
0+ \\
2+ \\
0 \\
0 \\
10+ \\
0 \\
0 \\
\end{aligned}$ & $\begin{array}{c}0 \\
0 \\
0 \\
0 \\
0 \\
40 \\
0+ \\
0 \\
153+ \\
0 \\
0 \\
10+ \\
0 \\
0\end{array}$ & $\begin{array}{c}2 \\
? \\
3 \\
3 \\
3 \\
3 \\
0 \\
2 \\
2 \\
3 \\
0 \\
20 ? \\
50 \\
\end{array}$ & $\begin{array}{c}\vdots \\
\vdots \\
7+ \\
\vdots \\
\vdots \\
1+ \\
\vdots \\
2+ \\
\vdots \\
\vdots\end{array}$ & $\begin{array}{c}5+ \\
7+ \\
8+ \\
3+ \\
\vdots \\
4+ \\
4+ \\
5+ \\
8+ \\
7+ \\
10+ \\
1 \\
\end{array}$ \\
\hline $\begin{array}{l}\text { Polythene bags. Tubing } 21 / 2 \mathrm{ft} \text { wide } \\
\text { Heavy-duty poly sheeting } 3 \mathrm{ft} \text { wide } \\
\text { Polybags, large heavy-duty clear } \\
\text { wo black dustbin } 1 \text { iners } \\
\text { " heavyduty } 211 / 2 \times 11 / 2 \mathrm{ft} \\
\text { " medium green } \\
\text { " small green } \\
\text { Paper gash-sacks } \\
\text { Plastic 2-gallon bucket }\end{array}$ & $\begin{array}{l}\mathrm{Ph} \\
\mathrm{Ph} \\
\mathrm{Ph} \\
\mathrm{Ph} \\
\mathrm{Ph} \\
\mathrm{Ph} \\
\mathrm{Ph} \\
\mathrm{Re} \\
\mathrm{Ph}\end{array}$ & $\begin{array}{c}\vdots \\
\vdots \\
\vdots \\
-6 \\
\vdots \\
7+ \\
\vdots \\
7+ \\
\end{array}$ & $\begin{array}{l}5+ \\
3+ \\
7+ \\
6+ \\
3+ \\
5+ \\
5+ \\
6+ \\
3+ \\
\end{array}$ & & $\begin{array}{l}\text { roll } \\
\text { roll } \\
\text { no } \\
\text { no } \\
\text { no } \\
\text { no } \\
\text { no } \\
\text { no } \\
\text { no } \\
\end{array}$ & $\begin{array}{r}1+ \\
1+ \\
1+ \\
100+ \\
500+ \\
500+ \\
800+ \\
50+ \\
4+\end{array}$ & $\begin{array}{r}1 \\
0 \\
0+ \\
-900+2 \\
0+ \\
-900+5 \\
800+1 \\
200+ \\
3+ \\
3+\end{array}$ & $\begin{array}{r}0 \\
0 \\
0 \\
200 \\
0 \\
000 \\
100 \\
3 \\
10 \\
\end{array}$ & $\begin{array}{c}7+ \\
\vdots \\
-7 \\
\vdots \\
\vdots \\
\vdots\end{array}$ & $\begin{array}{l}3+ \\
-3 \\
5+ \\
1+ \\
3+ \\
1+ \\
-3 \\
4+ \\
4+ \\
\end{array}$ \\
\hline $\begin{array}{l}\text { Huts. Triwall cardboard hut } 10 \times 6 \mathrm{ft} \\
\text { Structaply wooden hut } 8 \times 8 \mathrm{ft} \\
\text { RN Hydrographers portable hut } \\
\end{array}$ & $\begin{array}{ll}L L d & R J \\
\text { SJ } & \text { SJ }\end{array}$ & & $1+$ & $*$ & $\begin{array}{l}\text { no } \\
\text { no } \\
\text { no } \\
\end{array}$ & $\begin{array}{l}0 \\
0 \\
0 \\
\end{array}$ & $1_{0}^{1+}$ & $\begin{array}{l}0 \\
1 \\
0 \\
\end{array}$ & $\vdots$ & $\begin{array}{c}\vdots \\
\vdots \\
-2 \\
\end{array}$ \\
\hline 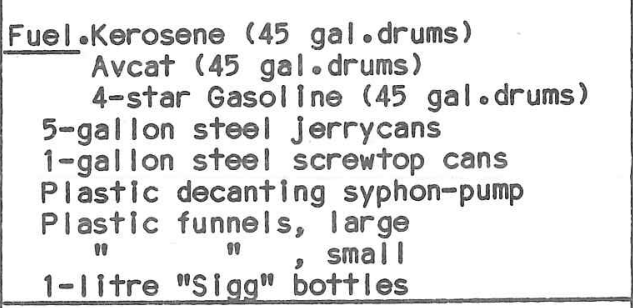 & $\begin{array}{c}\text { Various } \\
\text { He } \\
\text { Various } \\
\text { Ph } \\
\mathrm{Ph} \\
\mathrm{Ph} \\
\mathrm{Ph} \\
\mathrm{Mc} \\
\end{array}$ & $\begin{array}{c}\vdots \\
\vdots \\
7+ \\
7+ \\
\vdots \\
\vdots \\
7+ \\
\end{array}$ & $\begin{array}{c}4+ \\
-1 \\
\vdots \\
5+ \\
7+ \\
2+ \\
\vdots \\
10+ \\
\end{array}$ & & $\begin{array}{c}\text { drum } \\
\text { drum } \\
\text { drum } \\
\text { no } \\
\text { no } \\
\text { no } \\
\text { no } \\
\text { no } \\
\text { no } \\
\end{array}$ & $\begin{array}{r}4+ \\
5+ \\
8+ \\
100+ \\
10+ \\
0 \\
4+ \\
6+ \\
10+\end{array}$ & $\begin{array}{r}2+ \\
6+ \\
6\end{array}$ & $\begin{array}{c}? \\
0 \\
19 ? \\
? \\
0 \\
0 \\
0 \\
0 \\
0 \\
3 \\
\end{array}$ & $\begin{array}{c}\vdots \\
\vdots \\
\vdots \\
7+ \\
7+ \\
\vdots \\
\vdots \\
\end{array}$ & $\begin{array}{r}1+ \\
\vdots \\
5+ \\
10+ \\
7+ \\
1+ \\
\vdots \\
7+ \\
\end{array}$ \\
\hline $\begin{array}{l}\text { Matches (extra to rations).Safety } \\
\text { Windproof in cassettes } \\
\text { Metatab stove lighting tablets } \\
\text { Hexamine block stoves } \\
\text { Fire-blankets }\end{array}$ & $\begin{array}{l}\mathrm{Ph} \\
\mathrm{Ph} \\
\mathrm{Lf} \\
\mathrm{Rh} \\
\mathrm{Ph}\end{array}$ & $\begin{array}{c}\vdots \\
\vdots \\
7+ \\
\vdots \\
\end{array}$ & $\begin{array}{c}2+ \\
1+ \\
10+ \\
\vdots \\
1+ \\
\end{array}$ & & $\begin{array}{l}\text { doz } \\
\text { cass } \\
\text { pkts } \\
\text { stvs } \\
\text { no } \\
\end{array}$ & $\begin{array}{r}64+ \\
100+ \\
200+ \\
900 ?+ \\
12+ \\
\end{array}$ & $\begin{array}{l}-20+ \\
200+ \\
200+1\end{array}$ & $\begin{array}{c}0 \\
0 \\
100 \\
4003 \\
0 \\
\end{array}$ & $\begin{array}{c}7+ \\
7+ \\
-7 \\
-1 \\
7+ \\
\end{array}$ & $\begin{array}{l}-2 \\
-7 \\
\vdots \\
-4 \\
-7 \\
\end{array}$ \\
\hline 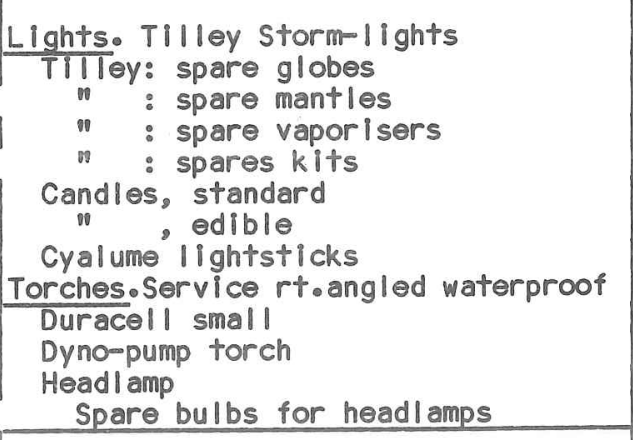 & $\begin{array}{l}\mathrm{Ph} \\
\mathrm{Ph} \\
\mathrm{Ph} \\
\mathrm{Mc} \\
\mathrm{Ph} \\
\mathrm{Lf} \\
\mathrm{Fc} \\
\mathrm{Ph} \\
\mathrm{Dh} \\
\mathrm{Dh} \\
\mathrm{Rd} \\
\mathrm{Rd}\end{array}$ & $\begin{array}{c}7+ \\
7+ \\
7+ \\
: \\
-2 \\
6+ \\
\end{array}$ & $\begin{array}{c}9+ \\
\vdots \\
\vdots \\
1+ \\
\vdots \\
1+ \\
4+ \\
9+ \\
5+ \\
\vdots \\
-1 \\
\vdots \\
-2 \\
\end{array}$ & $*$ & $\begin{array}{l}\text { no } \\
\text { no } \\
\text { no } \\
\text { no } \\
\text { no } \\
\text { doz } \\
\text { doz } \\
\text { no } \\
\text { no } \\
\text { no } \\
\text { no } \\
\text { no } \\
\text { no }\end{array}$ & $\begin{array}{c}0 \\
0 \\
0 \\
0 \\
0 \\
100+ \\
33+ \\
20 \\
16 \\
0 \\
10 \\
10 \\
20+\end{array}$ & $\begin{array}{r}8+ \\
8+ \\
200+ \\
0 \\
12+ \\
150+ \\
0 \\
30 \\
16 \\
5 \\
0 \\
10 \\
30 \\
\end{array}$ & $\begin{array}{r}0 \\
0 \\
0 \\
0 \\
0 \\
40 \\
0 \\
0 \\
3 \\
0 \\
0 \\
0 \\
3 \\
3\end{array}$ & $\begin{array}{c}\vdots \\
\vdots \\
\vdots \\
\vdots \\
\vdots \\
\vdots \\
-1 \\
7+ \\
\vdots\end{array}$ & $\begin{array}{c}5+ \\
8+ \\
\vdots \\
9+ \\
1+ \\
-2 \\
4+ \\
5+ \\
1+ \\
4+ \\
\vdots \\
\vdots+ \\
4+ \\
\end{array}$ \\
\hline Batterles. All sorts. & Various & & arious & ${ }^{*}-$ & doz & & $133+$ & 8 & & Varlous \\
\hline $\begin{array}{l}\text { Thesives, tools, wo } 40 \text {, screws } \\
\text { ce excluded from this report } \\
\text { space. }\end{array}$ & & & & * & & & & & & \\
\hline
\end{tabular}

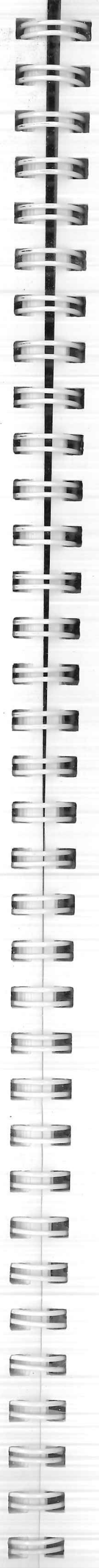

105

\begin{tabular}{|c|c|c|c|c|c|c|c|c|c|c|c|}
\hline \multirow{3}{*}{ ITEM } & $\begin{array}{c}\text { SOURCE } \\
\text { se®APp } 4 H\end{array}$ & \multirow{2}{*}{\multicolumn{2}{|c|}{\begin{tabular}{|c|} 
QUALITY \\
VOTES \\
+ Excellent \\
$\vdots$ Satisfact \\
- Poor
\end{tabular}}} & \multirow{3}{*}{\begin{tabular}{|l|}
$R$ \\
$G$ \\
$S$ \\
$R$ \\
$Q$ \\
$P$ \\
$P$ \\
$r$ \\
+
\end{tabular}} & \multicolumn{5}{|c|}{ QUANTITY TAKEN } & \multirow{2}{*}{\multicolumn{2}{|c|}{$\begin{array}{l}\text { QUANTITY } \\
\text { VOTES } \\
\text { More needed } \\
\text { Adequate } \\
\text { Too much } \\
\end{array}$}} \\
\hline & \multirow{2}{*}{$\begin{array}{|ll|}M & s \\
a & u \\
k & p \\
e & p\end{array}$} & & & & \multirow{2}{*}{\multicolumn{2}{|c|}{$\begin{array}{l}D \\
E \\
N \\
N \\
O \\
M\end{array}$}} & \multirow{2}{*}{\begin{tabular}{|l|}
15 \\
10 \\
men
\end{tabular}} & \multirow{2}{*}{$\begin{array}{l}\text { ow } \\
12 \\
\text { men }\end{array}$} & \multirow{2}{*}{$\begin{array}{l}25 \\
17 \\
\text { men }\end{array}$} & & \\
\hline & & $\begin{array}{c}15 \\
\max 7\end{array}$ & OW & & & & & & & $\begin{array}{c}15 \\
\max 7\end{array}$ & $\begin{array}{l}\text { OW } \\
\max 10\end{array}$ \\
\hline $\begin{array}{l}\text { Rucksacks.Crusader main pack } \\
\text { Condor main packs } \\
\text { Service arctlic framed pack } \\
\text { Delta } 45 \text { daysack } \\
\text { Daysack } \\
\text { Stuffsacks } \\
\text { Compression sacks } \\
\end{array}$ & $\begin{array}{ll}\mathrm{Bb} & \mathrm{Sl} \\
\mathrm{Ka} & \mathrm{Ka} \\
\mathrm{Bb} & \mathrm{Lf} \\
\mathrm{Ba} & \mathrm{Bb} \\
\mathrm{Ka} & \mathrm{Ka} \\
\mathrm{Te} & \mathrm{Te} \\
\mathrm{Be} & \mathrm{Be} \\
\end{array}$ & $\begin{array}{c}4+ \\
\vdots \\
\vdots\end{array}$ & $\begin{array}{c}9+ \\
10+ \\
9+ \\
9+\end{array}$ & $\begin{array}{l}* \\
* \\
* \\
* \\
*\end{array}$ & $\begin{array}{l}\text { no } \\
\text { no } \\
\text { no } \\
\text { no } \\
\text { no } \\
\text { no } \\
\text { no }\end{array}$ & & $\begin{array}{c}10+ \\
0+ \\
4+ \\
10+ \\
0+ \\
20 \\
0 \\
\end{array}$ & $\begin{array}{c}12 \\
0 \\
0 \\
6 \\
0 \\
0 \\
24 \\
0 \\
\end{array}$ & \begin{tabular}{r|}
0 \\
18 \\
0 \\
0 \\
10 \\
60 \\
16 \\
\end{tabular} & $\begin{array}{c}\vdots \\
\vdots \\
-7 \\
\vdots \\
7+ \\
\vdots \\
\end{array}$ & $\begin{array}{c}3+ \\
\vdots \\
-2 \\
2+ \\
\vdots \\
8+ \\
\vdots \\
\end{array}$ \\
\hline $\begin{array}{l}\text { SnowshovelsoBull dog full-size } \\
\text { Lightwelght full-size } \\
\text { Havywerght, Leith whaling station } \\
\text { Norweglan army small, spoon blade } \\
\text { Norweglan army small, flat blade } \\
\text { Small folding trenching tool } \\
\text { Icesaws.standard service AT icesaw } \\
\text { Woodsaws, modififid handles } \\
\text { Service icesaws (chain cutters!) } \\
\end{array}$ & $\begin{array}{ll}\text { Wc } & \text { Lf } \\
\text { Wc } \\
& H a \\
& L f \\
\text { Ya } & L f \\
\text { Ya } & Y a \\
& R a \\
& \text { La } \\
\end{array}$ & $\begin{array}{c}7+ \\
\vdots \\
\vdots \\
\vdots \\
\vdots \\
\end{array}$ & $\begin{array}{c}10+ \\
-4 \\
6+ \\
7+ \\
-6 \\
\vdots \\
3+ \\
-3 \\
-5 \\
\end{array}$ & * & $\begin{array}{l}\text { no } \\
\text { no } \\
\text { no } \\
\text { no } \\
\text { no } \\
\text { no } \\
\text { no } \\
\text { no } \\
\text { no }\end{array}$ & & & $\begin{array}{l}0+ \\
0+ \\
5+ \\
0+ \\
0+ \\
0+ \\
0+ \\
0+ \\
2+ \\
2+\end{array}$ & $\begin{array}{l}3 \\
0 \\
0 \\
? \\
3 \\
0 \\
? \\
0 \\
0 \\
\end{array}$ & $\begin{array}{c}7+ \\
\vdots \\
\vdots \\
7+ \\
\vdots \\
\vdots \\
-7\end{array}$ & $\begin{array}{l}7+ \\
3+ \\
2+ \\
9+ \\
4+ \\
-1 \\
9+ \\
-2 \\
-7 \\
\end{array}$ \\
\hline $\begin{array}{l}\text { Knives.RN seaman's clasp-knife } \\
\text { Army issue clasp-knife } \\
\text { Swiss Army knife } \\
\text { Lanyards } \\
\text { Keyrings (zip) } \\
\end{array}$ & $\begin{array}{l}\mathrm{Ph} \\
\mathrm{Rd} \\
\end{array}$ & & $\begin{array}{c}-3 \\
3+ \\
10+ \\
-2 \\
2+ \\
\end{array}$ & & $\begin{array}{l}\text { no } \\
\text { no } \\
\text { no } \\
\text { no } \\
\text { no }\end{array}$ & & $\begin{array}{r}10 \\
0 \\
3+ \\
30 \\
50+ \\
\end{array}$ & $\begin{array}{r}10 \\
2 \\
8 \\
30 \\
0+ \\
\end{array}$ & $\begin{array}{r}16 \\
3 \\
3 \\
0 \\
0 \\
\end{array}$ & $\begin{array}{c}-7 \\
\vdots \\
-6 \\
\vdots\end{array}$ & $\begin{array}{l}1+ \\
4+ \\
5+ \\
-4 \\
-3 \\
\end{array}$ \\
\hline $\begin{array}{l}\text { Watches, various } \\
\text { Spare service nylon watch-straps } \\
\text { Alarm. clocks } \\
\text { Compass, silva } 15 \\
\text {, survival button } \\
\text { Altimeter, Thommen } \\
\text { Binoculars, Sunnto } \\
\text { Binious }\end{array}$ & $\begin{array}{l}\mathrm{Ph} \\
\mathrm{Ph} \\
\mathrm{Ph} \\
\mathrm{Rd} \\
\mathrm{LA} \\
\mathrm{Rd} \\
\mathrm{Rg} \\
\mathrm{Ph}\end{array}$ & $\begin{array}{c}1+ \\
\vdots \\
\vdots \\
\vdots \\
7+ \\
\vdots \\
\vdots\end{array}$ & $\begin{array}{c}3+ \\
10+ \\
-8 \\
9+ \\
-4 \\
9+ \\
-9 \\
-4 \\
\end{array}$ & $*$ & $\begin{array}{l}\text { no } \\
\text { no } \\
\text { no } \\
\text { no } \\
\text { no } \\
\text { no } \\
\text { no }\end{array}$ & & $\begin{array}{l}11+ \\
20+ \\
5+ \\
10+ \\
10+ \\
6+ \\
3+ \\
3+ \\
\end{array}$ & $\begin{array}{c}13 \\
40+1 \\
3 \\
12+2 \\
6 \\
4+ \\
0 \\
1+ \\
\end{array}$ & $\begin{array}{r}16 \\
20 \\
0 \\
20 \\
0 \\
0 \\
0 \\
8 \\
\end{array}$ & $\begin{array}{c}\vdots \\
\vdots \\
-7 \\
\vdots \\
\vdots \\
7+ \\
\vdots \\
7+\end{array}$ & $\begin{array}{c}5+ \\
\vdots \\
-7 \\
5+ \\
1+ \\
9+ \\
9+ \\
4+ \\
4+\end{array}$ \\
\hline $\begin{array}{l}\text { Emergency. Plastic whistle } \\
\text { Avalanche cords } \\
\text { Pieps II avalanche transceiver } \\
\text { Avalanche probes } \\
\text { Personal FA kit (standard "soapdish") } \\
\text { Glacier cream, red (Uvistat better) } \\
\text { Lipsalve } \\
\text { First aid manual } \\
\text { "Hot Mini" warming pads }\end{array}$ & $\begin{array}{l}L f \\
O b \\
S d \\
D C \\
D C \\
D C \\
C g \\
C g\end{array}$ & $\begin{array}{c}\vdots \\
\vdots \\
\vdots \\
\vdots \\
7+ \\
\vdots\end{array}$ & $\begin{array}{c}2+ \\
-1 \\
-9 \\
-6 \\
-2 \\
-2 \\
8+ \\
6+ \\
4+ \\
\end{array}$ & * & $\begin{array}{l}\text { no } \\
\text { no } \\
\text { no } \\
\text { no } \\
\text { no } \\
\text { tube } \\
\text { tube } \\
\text { no } \\
\text { no }\end{array}$ & $\begin{array}{ll}0 & 1 \\
0 & 1 \\
0 & 1 \\
0 & 1 \\
0 & 1 \\
0 & 1 \\
b & 2 \\
0 & 2 \\
0 & 1 \\
\end{array}$ & $\begin{array}{ccc}10 & \\
10 \\
10 \\
10 \\
0 \\
10 \\
3 \\
20 \\
10 \\
10 \\
0 & 3 \\
0 & 1 \\
\end{array}$ & $\begin{array}{r}12 \\
10 \\
2+ \\
30 \\
12 \\
8 \\
300 \\
12 \\
100+\end{array}$ & \begin{tabular}{r|r}
40 \\
0 \\
0 \\
0 \\
17 \\
17 \\
3 \\
3 \\
3 \\
0 \\
\end{tabular} & $\begin{array}{c}\vdots \\
-7 \\
\vdots \\
-7 \\
\vdots \\
\vdots \\
\end{array}$ & $\begin{array}{c}\vdots \\
-5 \\
5+ \\
-2 \\
\vdots \\
-4 \\
-1 \\
: \\
\end{array}$ \\
\hline $\begin{array}{l}\text { Bamboo marker wands } \\
\text { Orange minefleld tape (or motorway) } \\
\text { Flags \& ensigns, various }\end{array}$ & $\begin{array}{c}\text { Var ious } \\
L \uparrow \\
\mathrm{Ph}\end{array}$ & $\begin{array}{c}7+ \\
7+ \\
0\end{array}$ & $\begin{array}{l}5+ \\
2+ \\
3+ \\
\end{array}$ & & & & $\begin{array}{l}00+2 \\
10+ \\
25+ \\
25+\end{array}$ & $\begin{array}{c}250 \\
0+{ }^{5} \\
16+ \\
\end{array}$ & & $\begin{array}{c}7+ \\
\vdots \\
\end{array}$ & $\begin{array}{l}5+ \\
3+ \\
-2 \\
\end{array}$ \\
\hline
\end{tabular}




\begin{tabular}{|c|c|c|c|c|c|c|c|c|c|c|c|}
\hline \multirow{3}{*}{ ITEM } & \multicolumn{2}{|c|}{$\begin{array}{c}\text { SOURCE } \\
\text { Se®APP4H }\end{array}$} & \multirow{2}{*}{\multicolumn{2}{|c|}{$\begin{array}{c}\text { QUAL ITY } \\
\text { VOTES } \\
+ \text { Excellent } \\
\text { : Sat isfact } \\
- \text { Poor }\end{array}$}} & \multirow{3}{*}{$\begin{array}{l}n \\
\theta \\
p \\
0 \\
r \\
t\end{array}$} & \multicolumn{4}{|c|}{ QUANTITY TAKEN } & \multirow{2}{*}{\multicolumn{2}{|c|}{$\begin{aligned} & \text { QUANTITY } \\
& \text { VOTES } \\
+ & \text { More needec } \\
: & \text { Adequate } \\
- & \text { Too much }\end{aligned}$}} \\
\hline & & & & & & \multirow{2}{*}{$\begin{array}{l}D \\
E \\
N \\
D \\
M\end{array}$} & \multirow{2}{*}{$\begin{array}{l}15 \\
10 \\
\text { men }\end{array}$} & \multirow{2}{*}{$\begin{array}{l}\text { OW } \\
12 \\
\text { men }\end{array}$} & \multirow{2}{*}{$\begin{array}{l}25 \\
17 \\
\text { men }\end{array}$} & & \\
\hline & & $\begin{array}{l}\mathrm{s} \\
\mathrm{u} \\
\mathrm{p} \\
\mathrm{p}\end{array}$ & $\begin{array}{l}15 \\
\max 7\end{array}$ & OW & & & & & & $\begin{array}{l}15 \\
\max 7\end{array}$ & OW 10 \\
\hline Ropes. 9mm Everdr I Kernmantel $45 \mathrm{~meter}$ & $\overline{O b}$ & & $:$ & $7+$ & & & $14+$ & $0+$ & & & $5+$ \\
\hline $9 \mathrm{~mm}$ Everdri Kernmantel 90meter & $\mathrm{Ob}$ & & : $>>$ & $4+$ & * & no & $6+2-14$ & $0+7$ & & $7+$ & $1+$ \\
\hline $11 \mathrm{mmm}$ Everdri Kernmantel $45 \mathrm{~meter}$ & Mo & & $:$ & $1 t$ & & no & $2+$ & $0+$ & 2 & $\therefore$ & $\vdots$ \\
\hline $\begin{array}{l}500 \mathrm{ft} \text { pre-stretched fixed ropes } \\
5 \text { ing }\end{array}$ & $\mathrm{Rd}$ & & : & $4+$ & & $\begin{array}{l}\text { no } \\
\text { no }\end{array}$ & $4+$ & 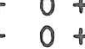 & & & $2+$ \\
\hline Hawser-laid $7 \mathrm{~mm}$ ny! & $\mathrm{Ph}$ & & $2+$ & $\because$ & & metr & $200+$ & $00+$ & & $\vdots$ & $2+$ \\
\hline $\begin{array}{l}\text { Hawser-laid } 5 \mathrm{~mm} \text { nyl } \\
5 \mathrm{~mm} \text { Kernmantel prus }\end{array}$ & $\begin{array}{l}P h \\
M c\end{array}$ & & $\vdots$ & & & $\underset{\substack{\text { metr } \\
\text { metr }}}{2}$ & 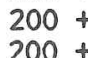 & $-300+$ & 200 & 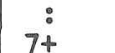 & $\frac{4+}{6+}$ \\
\hline $\begin{array}{l}5 \mathrm{~mm} \text { Kernmantel pru } \\
3 \mathrm{~mm} \text { braided nylon }\end{array}$ & $\mathrm{Ph}$ & & $\vdots$ & $4+$ & & metr & $200+$ & $-200+$ & & : & $\begin{array}{l}6+ \\
4+\end{array}$ \\
\hline $\begin{array}{l}\text { Made-up slings \& belay-loops } \\
\text { climbing tape.Troll inch "superblue" }\end{array}$ & $T_{\theta}^{R a}$ & & 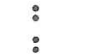 & 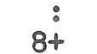 & * & no & & $-50+$ & & 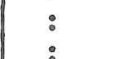 & $1+$ \\
\hline Elastic Shockcord $15 \mathrm{~mm}$ & $\mathrm{Ph}$ & & & $6+$ & & $\begin{array}{l}\text { metr } \\
\text { metr }\end{array}$ & $\begin{array}{l}100+ \\
250+\end{array}$ & 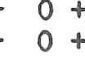 & & $\vdots$ & ${ }_{-1}^{8+}$ \\
\hline $\begin{array}{l}\text { Shockcord } 6 \mathrm{~mm} \\
\text { Made-up bungy straps (hook-ends) }\end{array}$ & $\begin{array}{ll}\text { Lf } \\
\text { f }\end{array}$ & & $\stackrel{:}{7+}$ & $\begin{array}{l}5+ \\
6+\end{array}$ & & metr & $\begin{array}{c}0+ \\
30+\end{array}$ & $\begin{array}{l}50+ \\
20+\end{array}$ & & $\vdots$ & $\begin{array}{l}4+ \\
8+\end{array}$ \\
\hline (Plus codline \& var lous cordage.) & & & & & & & & & & & \\
\hline $\begin{array}{l}\text { Cllmbing harness.ou } \\
\text { Whillans stituh }\end{array}$ & $\begin{array}{ll}T \theta & T e \\
T \theta & T e\end{array}$ & & $3+1$ & $\begin{array}{l}-2 \\
-3\end{array}$ & $*$ & no & 3 & & & $\vdots$ & $\vdots$ \\
\hline it +legloops) & $\mathrm{Te}_{\mathrm{TO}} \mathrm{Te}$ & & $:$ & $6+$ & $*$ & $\begin{array}{l}\text { no } \\
\text { no }\end{array}$ & $\frac{9}{2}$ & $6^{+}$ & & $\vdots$ & $:$ \\
\hline $\begin{array}{l}\text { ¿Europa chest- } \\
\text { (Freostyle slt }\end{array}$ & & & & $1+$ & * & no & & 8 & & & $\therefore$ \\
\hline $\begin{array}{l}\text { (Freestyle sit-harness (belt+loops) } \\
\text { Hol sters }\end{array}$ & & & $\vdots$ & $\begin{array}{l}1+ \\
-5\end{array}$ & $*$ & $\begin{array}{l}\text { no } \\
\text { no }\end{array}$ & 20 & 20 & $\begin{array}{l}0 \\
7\end{array}$ & $\vdots$ & $\stackrel{:}{-3}$ \\
\hline$\frac{\text { Climbing helmets }}{\text { Mountaln Pulk Sledges }}$ & & & $\frac{:}{7+}$ & $3+$ & 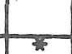 & no & 10 & & & & -5 \\
\hline SkisoRM wooden, cable bindings & 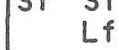 & & & -4 & & pair & $\begin{array}{r}10 \\
0\end{array}$ & $30+$ & $0_{0}^{0}-(-2)$ & $:$ & $\begin{array}{ll}8+ \\
-7\end{array}$ \\
\hline Dynastar Yeti 1800 & DJ Ed & & $7+$ & $10+$ & $*$ & pair & & & & $\vdots$ & $6+$ \\
\hline Emery "Altitude Plus" bindings & & & $7+$ & $10+$ & * & pair & $12+$ & $1+$ & & & $9+$ \\
\hline $\begin{array}{l}\text { Salewa } 120 \mathrm{~cm} \text { ski is/sillobinidin } \\
\text { schafer skis/Tyroler bindings }\end{array}$ & sb $\mathrm{sb}$ & & & $\begin{array}{l}-2 \\
-1\end{array}$ & * & pair & $\begin{array}{l}0 \\
0\end{array}$ & & 0 & $:$ & $\begin{array}{l}-2 \\
-2\end{array}$ \\
\hline Ski repair outfit & & & & & & no & $4+$ & & & & -1 \\
\hline $\begin{array}{l}\text { Spare slip-on } \\
\text { Spares }\end{array}$ & & & $\vdots$ & & & no & $4+$ & $=0+$ & & $:$ & $1+$ \\
\hline $\begin{aligned} \text { Spares k } \\
\text { Skins, Pomo }\end{aligned}$ & & & $7+$ & $9+$ & * & pair & 12 & & 0 & $:$ & $\begin{array}{l}6+ \\
8+\end{array}$ \\
\hline Another sort of stick-on & & & & $1+$ & & pair & 0 & 0 & 15 & $\therefore$ & : \\
\hline $\begin{array}{l}\text { Pomoca adhesive for skins } \\
\text { Harschelsen (ski "crampons") }\end{array}$ & & & $1+$ & $1+$ & & $\begin{array}{l}\text { Tube } \\
\text { pair }\end{array}$ & 10 & $\begin{array}{r}20 \\
0\end{array}$ & 15 & 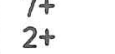 & $2+$ \\
\hline$\frac{\text { Metal ski-sticks }}{\text { Spare baskets for ski-sticks }}$ & & & 7+: & 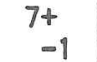 & & $\begin{array}{c}\text { pair } \\
\text { no }\end{array}$ & 16 & $\begin{array}{ll}16+ \\
4+\end{array}$ & $\begin{array}{r}30 \\
0\end{array}$ & & $\begin{array}{c}7+ \\
-2\end{array}$ \\
\hline Ski-waxes $1+$ scraper & & & & & & tubs & & & & & $\begin{array}{l}-2 \\
-9\end{array}$ \\
\hline Crampons. LO & $\mathrm{Fa}$ & & $7+$ & $10+$ & $*$ & pair & 10 & 12 & 10 & $:$ & $\therefore$ \\
\hline $\begin{array}{l}\text { Snow } \\
\text { Salewa adjus }\end{array}$ & $\begin{array}{l}\text { Ac } \\
\mathrm{Ra}\end{array}$ & & 7+: & $\begin{array}{l}6+ \\
-2\end{array}$ & & $\begin{array}{l}\text { pair } \\
\text { pair }\end{array}$ & $\begin{array}{r}10 \\
4\end{array}+$ & & 10 & & $\begin{array}{l}3+ \\
-5\end{array}$ \\
\hline Ice-axes-Servic & Ra & & $i_{-6}$ & $\begin{array}{l}-2 \\
-3\end{array}$ & & no & $1+$ & $3+$ & 0 & $:$ & -4 \\
\hline IT metal-shafted & $\mathrm{Ra}$ & & $7+$ & $5+^{-3}$ & $*$ & no & $6+$ & $2+$ & $\begin{array}{l}0 \\
0\end{array}$ & $:$ & $8+3$ \\
\hline Various & & & 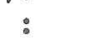 & $5+$ & $*$ & no & 0 & 6 & & $:$ & $2+$ \\
\hline $\begin{array}{l}\text { Super Zero Iceaxes } \\
\text { I cehammers "Terrordacty Is" }\end{array}$ & $\begin{array}{l}A b \\
R d\end{array}$ & & & -2 & & no & $10+$ & ${ }^{0}+$ & $\begin{array}{r}18 \\
0\end{array}$ & $\vdots:$ & $\stackrel{\dot{1}}{1+}$ \\
\hline I cenhammers & & & $3+$ & $2+$ & * & no & 2 & 0 & 0 & $3+$ & $2+$ \\
\hline $\begin{array}{l}\text { Varlous other personal icehammers } \\
\text { Chouinard }\end{array}$ & ct & & & & ${ }_{*}^{*}$ & no & 1 & 2 & $0_{5}^{0}$ & $\therefore$ & $3+$ \\
\hline Belays:De & Ra & & 0 & $8+$ & & no & $10+$ & $0+$ & & $1+$ & $\frac{1+}{8+}$ \\
\hline $\begin{array}{l}\text { Deadboys } \\
\text { Snowstakes }\end{array}$ & $\mathrm{Rd}$ & & $\vdots$ & -3 & $*$ & no & $6+$ & $0_{0}^{+}$ & 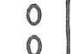 & $7+$ & -3 \\
\hline I cescrews . Lon & g & & $:$ & $2+$ & & no & $21+$ & $0+$ & 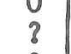 & : & $2+$ \\
\hline $\begin{array}{l}\text { :Sho } \\
\text { Snna }\end{array}$ & $\begin{array}{l}\mathrm{Ra} \\
\mathrm{Ra}\end{array}$ & & & $:$ & * & no & $8+$ & $0+$ & $?$ & $\therefore$ & $\therefore$ \\
\hline 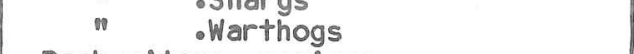 & $\mathrm{Rg}$ & & & $1 t$ & 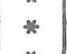 & $\begin{array}{l}\text { no } \\
\text { no }\end{array}$ & $10+$ & $0+$ & & $1+$ & $1+$ \\
\hline $\begin{array}{l}\text { Rock pitons, various } \\
\text { Chocks }\end{array}$ & Ra & & & & & no & $24+$ & $0+$ & 0 & $:$ & $1+$ \\
\hline Hardware Karabi & Rd & & $:$ & $3+$ & & $\frac{10}{\text { no }}$ & 100 & $0+$ & 63 & $:$ & $3+$ \\
\hline Descendeurs oF & $R d$ & & $:$ & & & $\begin{array}{l}\text { no } \\
\text { no }\end{array}$ & 16 & $\begin{array}{l}0+ \\
0+\end{array}$ & 10 & $7+$ & $\begin{array}{l}3+ \\
-4\end{array}$ \\
\hline and & Ra & & $7+$ & & * & 10 & 0 & $0+$ & $\begin{array}{l}0 \\
0\end{array}$ & $7+$ & $A+$ \\
\hline "I Clo & 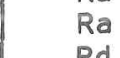 & & 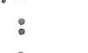 & $2+$ & 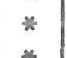 & $\begin{array}{l}\text { pair } \\
\text { pair }\end{array}$ & $2+$ & 0 & & & $3+$ \\
\hline $\mathrm{ClC}$ & & & & & & & & & & & \\
\hline
\end{tabular}

Choice of electrical equipment was one of the more complex problems dur in preparations. External constraints were: Finance; transport of petrol; possible uncertainty about mobility on the island; late decision to rationalise and prove charging systems.
One team member should be tasked to coordinate all electrical equipmento

Petrol-enE SUPPLY. It is important to decide early what power unit will be used if any.
Petroble Generator seto Our Honda weighed about 70 lbs and delivered about $2 \mathrm{KW}$ at $50 \mathrm{HzAC}$ (230 or 115 volts) or DC (24 or 12v). Two (or even one) smal ler sets are useful, but the AC outputs alone would suffice. The Honda ran well initially, but lafter several minor defects) a field winding fallure put it out of action.
Solar Panels. The Second Summer Party obtalned two solar panels on loan from the SAS. Wind Generator. The RN Englneer ing Col lege made a neat one for us, unfortunately damaged by a falling craneloado If petrol is not required for other expedifion uses, consider
buying a yacht's wind generator, for trickle charging large batteries. buying a yacht's Wind generator, for trick le charging large batteries.
Power Takeoffs. Our OMC outboard motors had I2V DC power outputs; so did our Skidoos originally. Custom bullt, waterproof charger-plus-battery packs are needed to use these, with the engines well loaded, travell ing. If large power units are required, a shaft power Man-powered Generators. The Clansman Radio hand generators were invaluable. A useful
mbicyclem generator, useable in tents, could be made for battery charging.

2. CHARGING UNITS AND ACCESSORIES. TYP ically, these interface equipments were the weak and lack of prior proving trials. Several capacitors also failed, possibly due to environmental conditionso A single charger unit for each power supply would be worthwhile, capacitors, wire, crocodile connectors, extension lead etco and an electrical toolk it including an Avo Multimeter.

3. BATTERIES. The variety needed grew bewilderingly. Rationalisation is desirable but Rechargeable Batter les. (NiCd) were more rellable than their charging unitso Spare 1.5v Ependab Batteries gave bettery colls wollable the thi to bul up battery packs. batterles lasted 4-5 times as long as (old? absolete type?) Service lssue batterikal ine latter also had inadequate initial output for Uher Tape Recorders, Flash guns and the Reaction Tester. Equipment design must al low for low battery output in low temperatures. Dry Storage must be arranged, including transito. Warming batter los (\& user units) before

4. USER EQUIPMENTS. Our list was probably typlcal for an expedition.

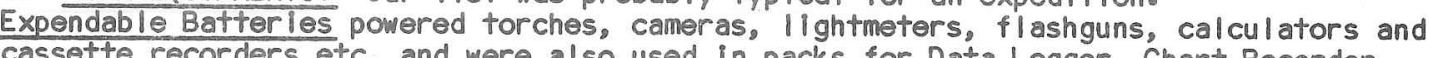
Digltal Thermometer, Infra-red Sensor, Night Vision Aids, Echosounder \& Reaction Tester. Rechargeable Batter ies were fitted in several equipments: Beaul ieu Cine Cameras (unuseable after generator $230 \mathrm{~V}$ AC control capacitc
Uher Tape Recorders (Sat'sfactory fallback using Duracell batter les) Clansman Radios (Satisfactory al ternative using Hand Generator). VHF Walkie-Talkies (Clumsy alternative using DiY battery pack). Oirect Power Rangefinder (Unusable after charging unit capacitor falture). AC or DC Heater for invertebrate extractor (I nfer lor faliback using TIIl ley Lamp). $230 V$ AC Centrifuge for blood samples (Inferlor fallback using hand centrif fuge).
$230 V$ AC Soldering I ron (Alternatives were lower capacity battery powered, and spoons 230V AC Lighting necklace (totally unnecessary - warm Tilley Lamps were better). 5. ADDITIONAL USER EQUIPMENTS. With a generator set the following would be nice: Hot Air Blower for drying adhesive Joints, electrical gear, blological specimens etc. curing GRP, forming plastic boots, hot cutter for ropes and textlles etc. etco
Arc Welding set for repairs and construction (NB. This would determine generator sizel). 


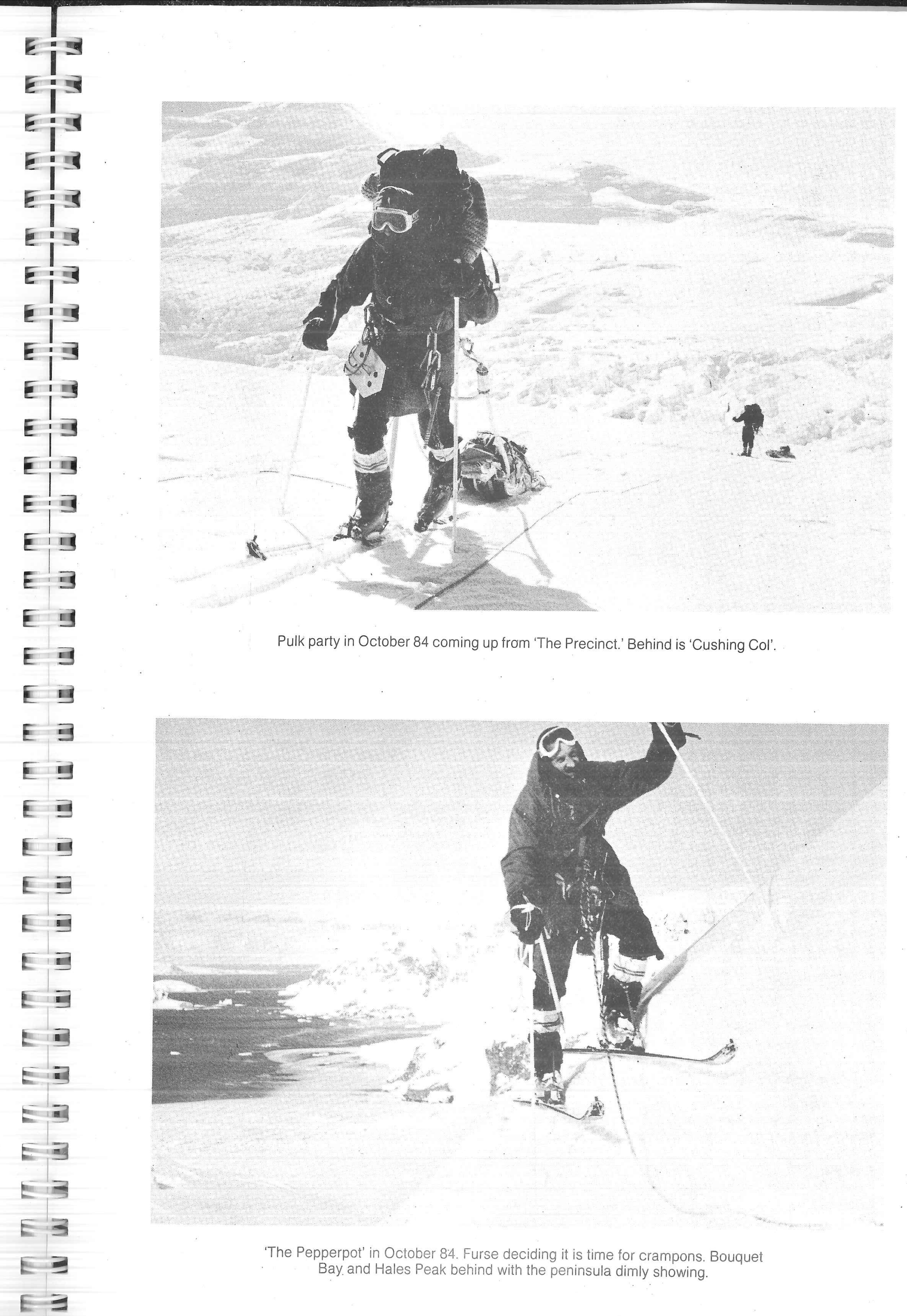




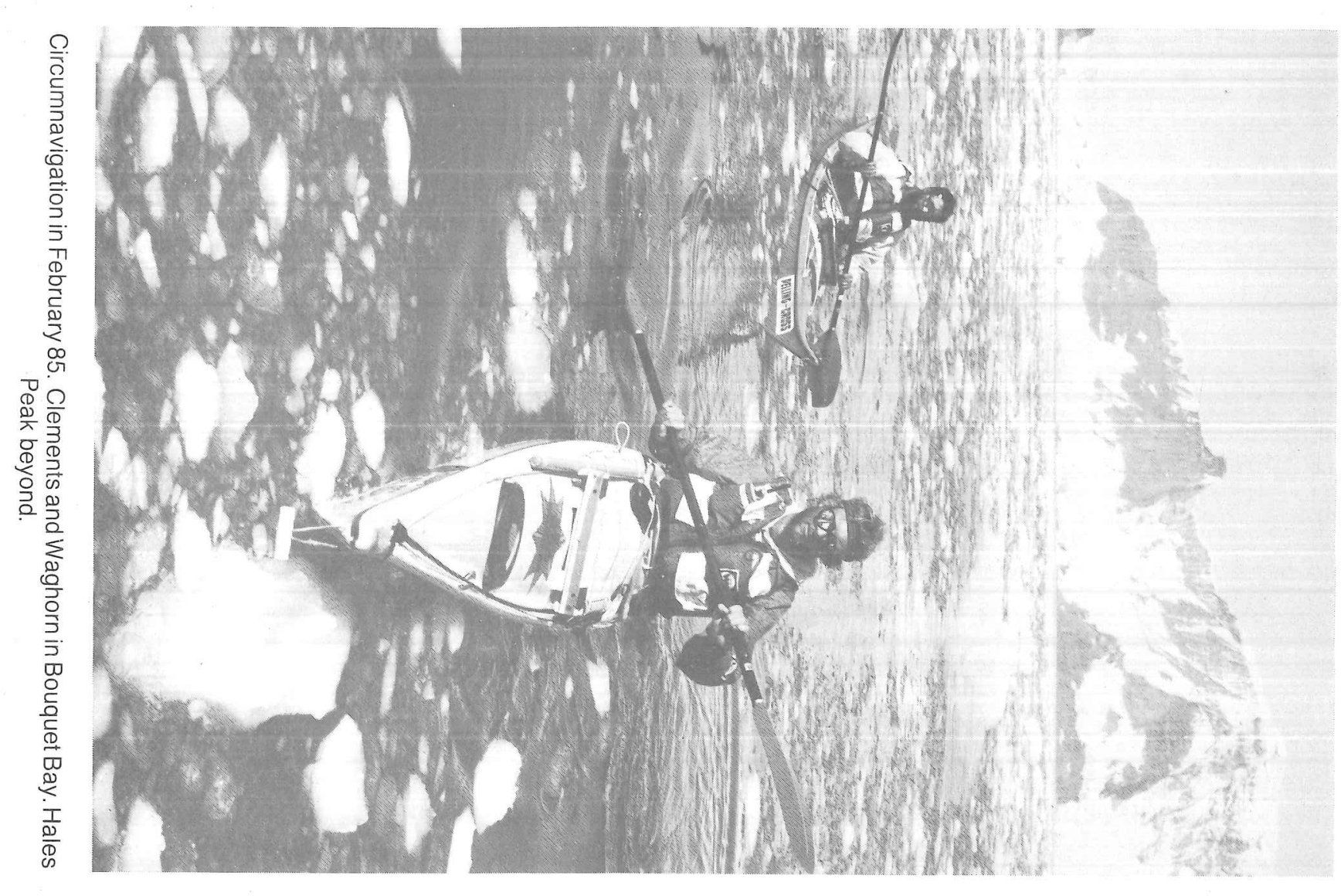

Leader's Expedition plans are first assessed by the adventure training authority of the by the Joint Services Expedition Trusto As our officlal Administrative Author Ity. summarles), and helped in many other ways. However a Joint Services Expedition has a position in the Services akin to a
neody artist, who is the cousin of a large familyo Most of the family are pre-disposes needy artist, who is the cousin of a large family, Most of the family are pre-disposed and familles to look after. Their response depends upon his personality and approach,
and upon their opinions of art in general and his paintings in particular.

This expedition succeeded because of the goodwill, interest and active help of
hundreds of organisations and thousands of individuals at home organisations and independant people who helped us. Regrettably, space prevented naming in our prepartlons. Returning from the island we chose just one person to name here "ispresent al" in "stores Auntilen in PSTO(N) Devonport. My whole team joins in a great big thank you to Mary

"squads" Most of the preparatory work was left until the First Summer and Overwinter the workload was spread as widely as possible mak the initial weekend team meet, responsible for at least one specific task. Three coordinators covered respectively Euten presented difficulties in coordinatlon. The training periods were each attended by about of continuity to 3-phase expedition without a permanent UK support staff added problems Summer squad of 23 was selected in september 83 . At a weekend meet in october $80 \%$ of then The training fortnight in January 84 , enabled $70 \%$ of the Second Summer to latter flew oute Party. All administrative tasks had been handed over to the Second Summer party bortor the Winter Party sal led. Waghorn was fully occupled in his job at BRNC Dartmouth until Waghorn was seconded to DNPTS for 3 months, adm nistrative task for himo Prior to departure
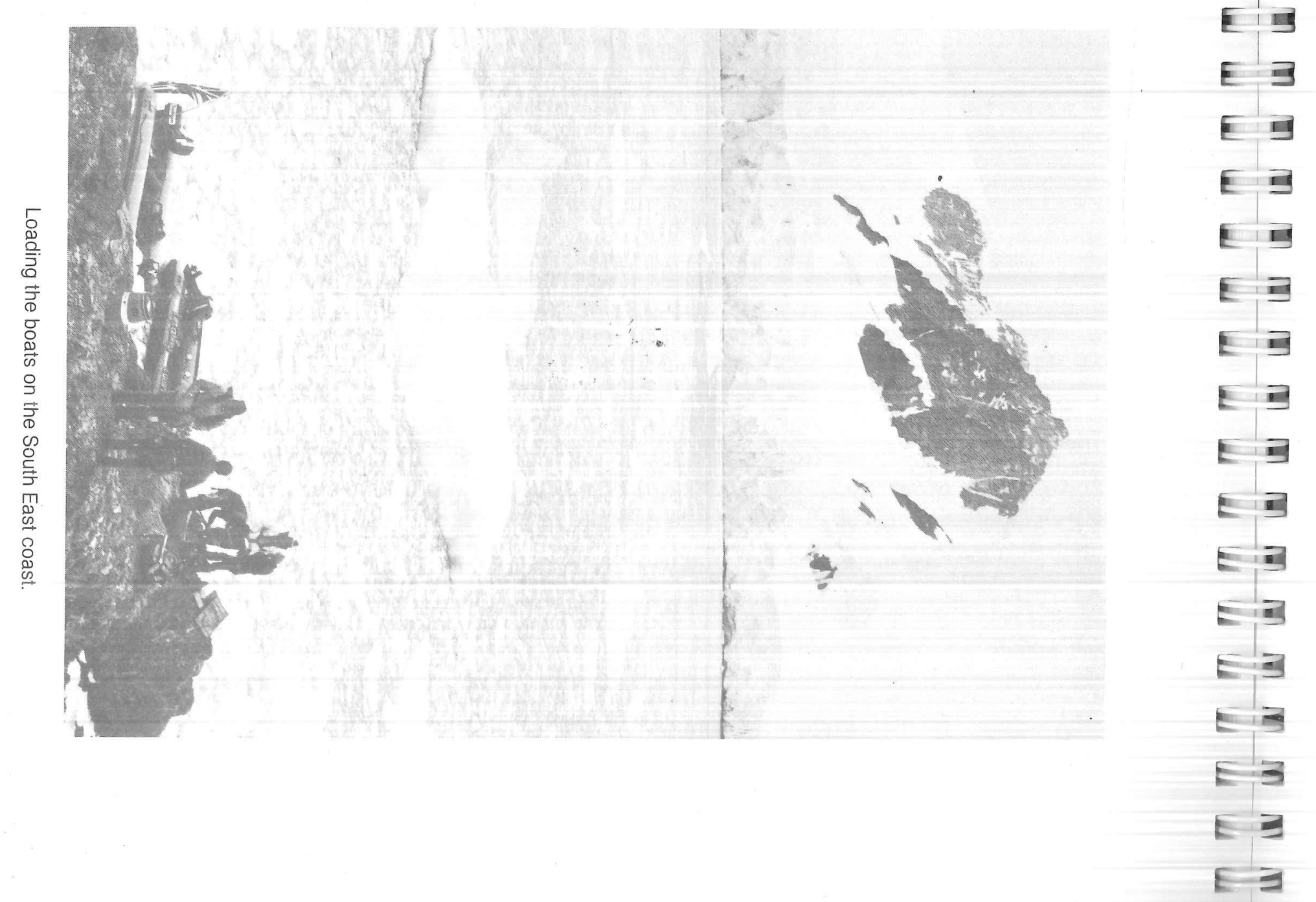

The three phases provided a totally involved Rearlink in Britain. During the breakdown in communications, with the island, which would otherwise have put an unfair load onto official service authorities.

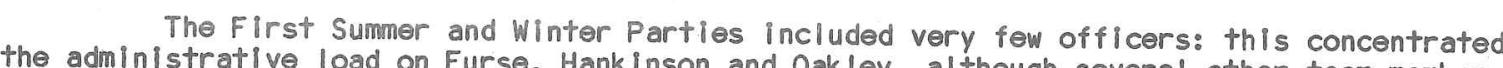
did help significantly. The second Summer preparations werg handicapped by team members Army officers in crucial administrative posts withdrawing from the expeditione From our experience that is sorely

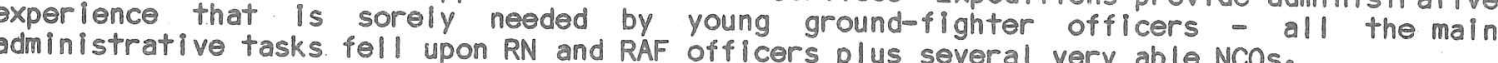
Post-expedition administrative load remains high, in order to ensure thorough spread, over 35 team members who know what they are talking about, and have all experienced
the magic of Antarctic islands. 


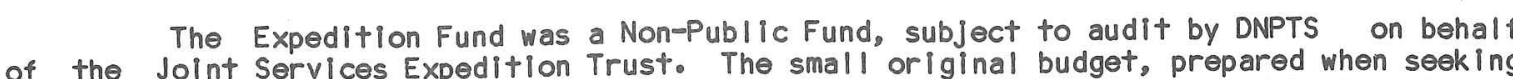
ondorsement, increased considerably as extra costs accrued for skidoos and boats. A goo momentum of fund raising in 1983 then indicated a surplus, and this was utili ised to Increase the size of all 3 parties, Forecasting a safe margin with the Rolex Award, funds having already helped us, fund ralsing was much harder in 1984. The credit balance at the time of writing does not quite meet the known forthcoming expenditures on report printing, photographic processing, and colour IIl lustrations for the book. However we hop that royalties, lecture fees, further.
expedition equipment will bridge the gap.

The budget history is summarised on the graph below:

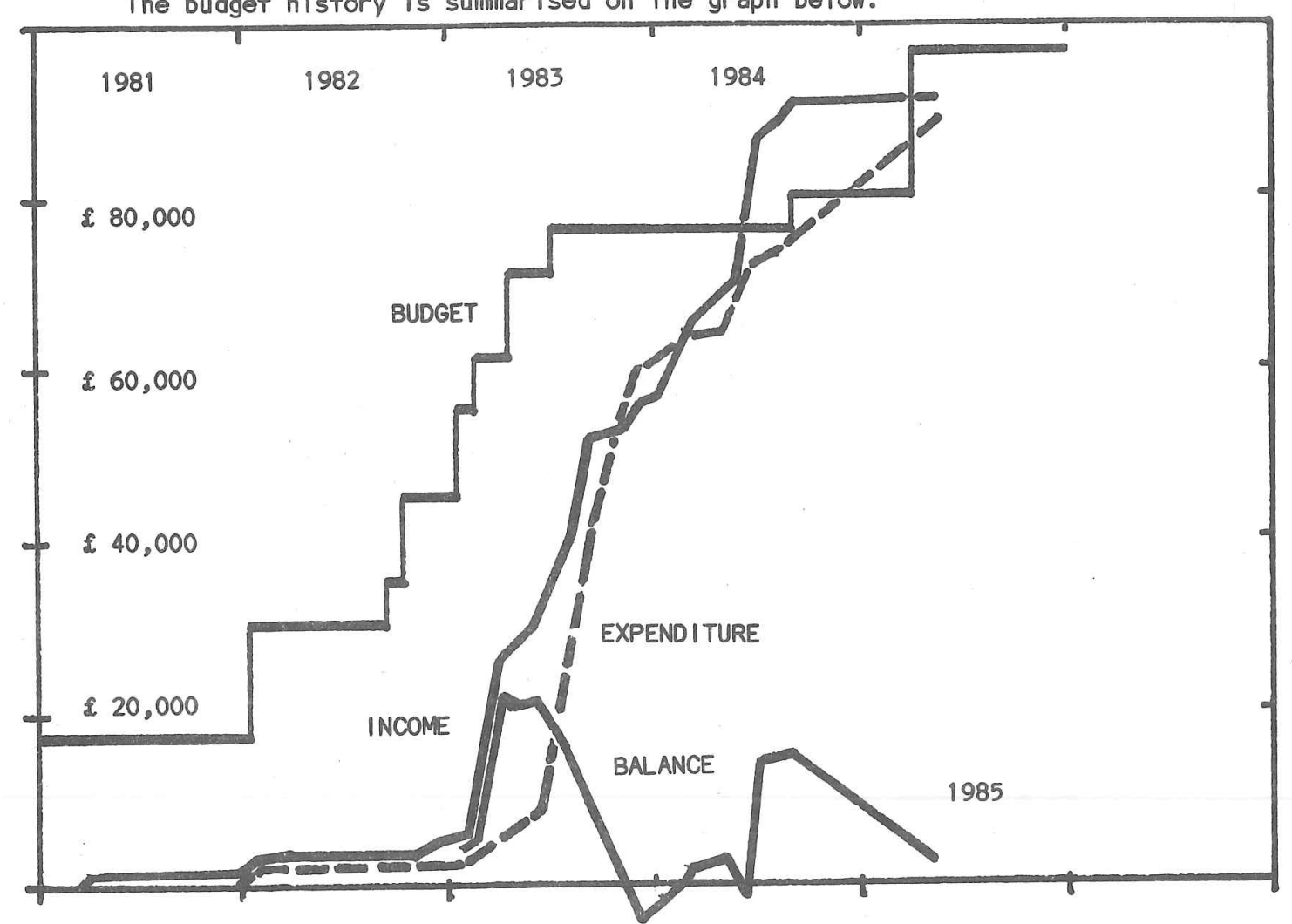

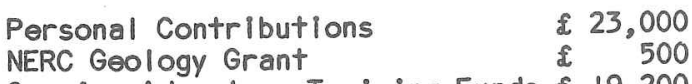
Service Non Public Funds (1) Civilian Institutions Fund Ralsing Activitios (2) Royalties
Equipment Sales

\section{Assured Income
(at mId May 1985)}

\begin{tabular}{|c|c|}
\hline $\begin{array}{l}\text { General Equipment } \\
\text { skidoos \& Sledges } \\
\text { cinefilm (nett) } \\
\text { still photography (nett) } \\
\text { scientific Equipment } \\
\text { Travel Fares } \\
\text { Freight Charges } \\
\text { Insurance } \\
\text { Printing } \\
\text { Post, Phone, Miscell aneous } \\
\text { Book Colour Subsidy }\end{array}$ & 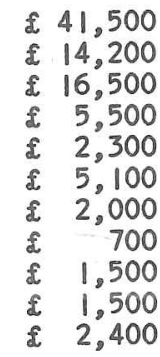 \\
\hline $\begin{array}{l}\text { Committed Expenditure } \\
\text { (at mid May } 185 \text { ) }\end{array}$ & 93,200 \\
\hline
\end{tabular}

Note (1). Service Non-Public Funds include central funds such as the "Sailors Fund", plus many grants from Unit and Command Wel fare Funds, and contributions from clubs, Messes, and
the Royal Marine Association of ex-servicemen. Note (2). Fund Raising activities include philately, raffles, sponsored runs, sweat shirts too shirts, postcards, ties etc.

In 1987 the Expedition Fund will be wound up and a final statement of account rendered to DNPTS, with supporting accounts avallabe remalning would be returned to the solnt
made up by the leader and team members.
One of our aims was to generate good public relations, showing the British
Services in an adventurous (and peaceful) role. As well as encouraging good recruits, this will encourage support for future JSEs, providing useful publicity for the commerclal
organisations who have supplied us, or helped in other ways.

A multi-alm expedition. with a scientific bias is not easy to sell to the medi and coverage was scant during the first year, without the regular articles we had expected to run an Expeditions column, (somewhere between the Sports Pages and Traval Sunday papers would provide a considerable boost to expeditions by encouraging comnercial sponsorsh is Apart from the growing public interest in such individual istic, non-competitive "leisure activities the paper(s) concerned would have prlority on coverage of the major storles
which are quite liable to arise, since most expeditions have an element of risk.

Waghorn's Many people, in many countries, now know where Brabant Island is, after clive Waghorn's crevasse fall and rescue. We are now building up a good momentum of post
expedition publicity as noted below. We are always pleased to provide material to ail supporting organisations, sponsors and suppliers.

1. COMMERCIAL ADVERTISEMENTS.

Equi ment reports are being provided to all suppliers, with endorsements wherever colour pral have already been usede colour Processing Laboratories Ltd are marketing brochures and poster

It is hoped that a group of commerclal sponsors and suppliers will

\section{WRITTEN MATERIAL}

We know of over 60 newspaper articles that have appeared, including two colour Syndicated Features Ltd are marketing general articles to magaz Ines worldwide,
and several have already been published. Team members have had a fow articles published in house magazines. A wide range
of magazines are now being approached and we expect over 50 articles to be published
eventually, plus several papers in the Sclentific press.

This report, and a technical photographic report, are each being distributed to about
distributions to manufacturers, the RGS, and the SPRI.

in Spring/Summer 1986. I have covered both the expedition to Brabant Island" richly illustrated book. Three other books on particular aspects are tentatively planned
by Atkins (mountain travel), Corbett and Hall (coffee table pictures) and Oakley (cold

3. STILL PHOTOGRAPHY

Over 40 different expedition pictures have already been used to ll lustrate
articles and advertisements. Many more illustrations will be published in magaz Ines over
the next year or two. Colour Processing Laboratories exhibited over two dozen large expedition
colourprints at Fotokino Cologne 1984: the CPL display with a $7 \mathrm{ft}$ x $4 \mathrm{ft}$ Flexiframe boat plcture is avail able through the Leader. Other displays have already been shown by Pelling and Cross and by Nikon and more are planned, including an Olymus Gallery exhibition.
corbett also hopes to arrange a travelling exhibition (in ald of Multiple Sclerosis

Photographs are avallable from CPL or the three expedition photographers who can be contacted through the leader. Early in 1986 a selection of expedition pictures wil commerclal basis.

4. LECTURES, PRESENTATIONS AND SHOW STANDS

October 1985: it it is hoped public presentation is at the Royal Geographical Society in avallable to give lectures and presentations, and several have already done so.

We expect the expedition to feature on several manufacturers stands at the next Harrogate Camping Show, the Earls Court Boat Show and Twickenham Canoe Show and hope that 


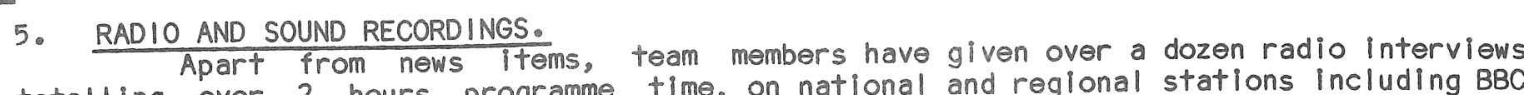
totalling over 2 hours progr
World Service and Radio Canada.

Oakley plans to produce a half hour radio feature from his winter phase recordings.

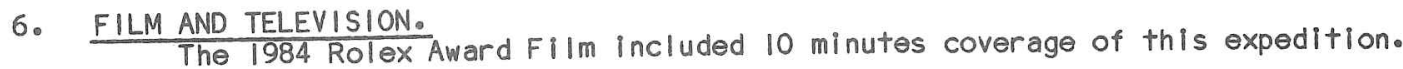

Pacesetter Enterprises Ltd. are marketing the expeditions cinefilm material. This was of good quality and at the time of writ to produce a 50 minute TV feature. The Expedition and pacesetters will retain rights for showing abroad, where there is known interesto

The expedition has featured on British TV about two dozen times, plus perhaps 50 news reports during Clive Waghorn's rescue. Coverage abroad has included a 5 minut
NBC IIve broadcast networked in the USA, plus coverage on Belgian and French programmes.

7. MISCELLANEOUS. widespread interest in Britain, France, Belgium, Italy, Switzerland, Austria, Norway, Sweden, East and West Germany, Czeckos lovak la, wss,
Zealand, the Falklands, and probably elsewhere as well.

The prestiglous Rolex Award for Enterprise made to the expedition in 1984 has

Corbett and Hall won a nomination for an IIford Award in 1984 for a First Summer photograph.

Make sure you:

See the TV filmo

Attend a Presentation.

visit an exhibition of photographs.

Buy the Calendar.

Buy the Book. "Antarctic Year: Expedition to Brabant Island"
by Chris Furse, to be published by Croom Helmo April 1986.

Any enquirles for publicity should be made to:

Surgeon Lieutenant Commander Howard Oakley, RN.

Brook lands Lodge,
Park View Close,

Wroxall, Vent,
Isla of Wight,

Isle of Wight, PO38.3EQ.
Telephone: 0983.853605
This expedition depended upon the magnificent assistance given by HMS ENDURANCE successive Commanding Officers (Captains NIck Barker, Col in McGregor and Pat Md aren) she provided active support, including the initial photographic reconnaissance in 1980/81, and

The main tasking priorities for Endurance set by Cinc Fleet are: 1. Inspections of bases under the Antarctic treaty. 2. Hydrographic Survey. 30 Support for BAS goodw Il that could easily be eroded by a dozen team members crowding the accommodatlon, while our stores crowded the holdo My 3 teams all wish to express their thanks to her
Captalns, Officers and entire Ship's Companies and Flights, who gave us such cheerful, enthusi astic, and above all efficient, helpon

After the announcement in June 1981 that Endurance would be withdrawn from
Service in 1982, the credibility of the expedition was kept allve by tenuous fallbacc

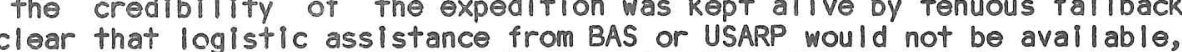
following a SCAR Logistics Committee resolution discouraging help to "private" expeditions like this. Nor was it possible to approach the Chilean forces for transporto Charter costs were prohibitive at over 22000 per day, so my uitimate fallback was smal ler parties
with uitra-light equipment, taking passage in tourist ships to and from Palmer Station, where our food and fuel was already cached.

Then the Argentines invaded the Falklands. Late in 1982 Endurance was reprieved,

The ships support must be approved in principle beforehand by her operating
Cinc Fleeto Support must be at minimal cost to operational tasks. So expedition plans must be al igned with the ships overall programme. This requires careful preparatory
staffiork with Commanding Officers, and with the Superintendant of Survey Planning in the
Hydrographic Department. Hydrographic Department。

Appendix 4E

THE FALKLAND ISLANDS

by Chris Furse

From the early planning stages, Sir Rex Hunt, the High Commissioner for British
Antarctic Territorles, had given his support to this expedition. He visited Metchnikof Point on 17 February 1984 to formally open our Sub Post Office there. He and Lady Hunt appreciated.

In 1981/82 the Royal Marines of Naval Party 8901 helped the expedition by local purchase of Kerosene, and handling our rations in transit.

During the expedition itself the much larger garrison than present on the Islands
gave us much assistance (particularly the FI Logistic Battallon and Queens Harbour Master but also many other units). It is important to realise that there is a rapid.change-round of Service stafts in - Stanley: continulty of contacts is therefore a problem for fringe

Station YPC transmissions were clearly received on Brabant Island, but 2-way Communication was seldom possible. Nevertheless several Winter Party messages were transmitted the

the 60S The Comnander British Forces Falk land Islands has operational control north of the 6os boundary of the Antarctic Fleaty Area, and hes jolnt stanter Party General de Labllllere was debriefed by Furse: tentative plans for future small, singlesummer, Service mountalneering expeditions to South Georgia, Smith Island and Brabant Adventure Training officer.

All three expedition parties found their brief stopovers in the friendly Falklands both enjoyable and useful. After completion of the new Stanley Airport, small, well-planned expeditions to the Antarctic should be easier to organise than ever before.
However the final legs by sea will remain a very difficult hurdle, with the possible
exception of South Georgla. 
During our preparations BAS staff at all levels gave very helpful advice to

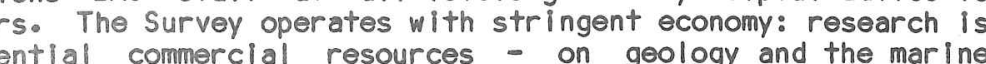
ecosystem. The efforts of BAS scientists are strlctly concentrated upon their own full research programmes. Involvement with a JSE would clearly absorb BAS sclentlsts' by unqualified amateurs. Nevertheless the Director of BAs agreed to consider collaboration With this expedition on specific projects, the criterion being whether or not the resulting Information was 1 kely to be worth the BAS effort involved. This rlgorous scrutiny proved able to work up potential projects with BAS scientists before the selfsame projects were approved. This was particularly difficult in the tightening research fleld of terrestrial blology, and again produced a healthy result - we located many researchers in Universities eager to recelve material from the Antarctic and welcoming this opportunity. In the
15 sclentific projects were arranged in collaboration with BAs, out of a total of 81 .

Dr Laws, Director of BAS, Kindly authorised Faraday Base to transmit 100 word bulletins back raday (together with those at Signy is land, Rothera and the USARP Palmer station) were our only regular contact with the outside worldo Over the long winter in particular they became famillar voices and indeed friends. We thank all of them for their which was so important.

When Evans developed a mild duodenal ulcer late in the winter, assistance was a call for help, and RRS John Biscoe picked him up from Metchnikoff Point, making him welcome as a passenger for 8 days to their next port of call at Punta Arenas. She also through the Gerlache Strait, she surprised the Dayglo Party with a lightning boat visit, giving them two boxes of fresh fruit and vegetables. A very friendly, but wary and precarlous symblosis exists between BAS and the
rare expeditions to the Antarctice. There is a tendency for Service expeditions to promise more than they achieve on the scientific front: this endangers the relationship, and rebounds on subsequent expeditions. (Any such promises are in any case fruitless, as they do not actually help gain support for the expedition). On Brabant Island we did set out to undertake thorough work within our capabilitieso We hope that the results from our
fieldwork will domonstrate agaln (I ike those from two JSEs to Elephant Island), that Joint
Service Expeditions can and do provide valuable additional scientific information on Antarctica.

One amusing instance revealed another ingredient in the BAS reaction to outside expeditions. BAS effort had not been approved for analysis of our arthropod samples, so we had made arrangements with Mike Usher of York University. When descriptions by radio BAS requested that de should supply our specimens to BAS for first analysiso. If the Antarctic were my parish, I too would want a private domain?
Ant

The underlying reason for the stiff formal stance taken by BAS toward expeditions to the Antarctic is the possibility of BAS being drawn into a rescue operation, because that would be expensive, and to expeditions during their preparations. However it must be

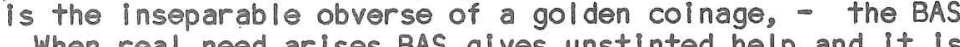
precisely because of this that expedition plans are viewed critically. The BAS reaction to real need was demonstrated magniflcently when Waghorn broke his leg. Ed Murton and his logging over 12 hours flying in appalling conditions: the sound of the Twin Otter overhead in the cloud was a marvellous fillip to Waghorn and Gill's morale, telling them that the others had got through to the radio and help would

Thank you BAS !

During the winter months evacuation would not have been possible. This required Doctor in the team, and determined the scale of medical and surgical equipment taken. exlst, because ships do pass Brabent is two sunners, the possi several weeks might elapse after an accident happening before evacuation

In the event one precautlonary medical evacuation and two casualy evacuations
ected between November 1984 and March 1985. Fortunately no serlous accidents were effected between November
occurred during the mi dwinter months.

Evans. In July, Evans developed clear symptoms of a mild duodenal ulcer.
These worsened in September, and Evans volunteered to remain alone at Point, in hope of evacuation. In reponse to a radio message requesting a Precautionary Medical. Evacuation, BAS agreed that RRS John Biscoe would pick him up on passant, at the beginning or end of November
when she was due to pass by. USARP al so agreed that the USCG I cebreaker Glacler could uplift him by hell copter in December if John Biscoe had been prevented by bad weather. In the event RRS John Biscoe picked Evans up by boat on 3 November. Evans was landed at Punta Arenas at the ship's next support command HQI Group Aeromedical section, in conjuction with the Servlces Booking Centre and the Defence Attache in Santiagoo After arriva in Britalng Evans was examined at Queen Ellzabeth Military Hospital,

Greenway. In January Greenway fractured his leg while lashing down stores there for several days until one of the expedition's doctors arrived. By chance the Canadian I cebreaker Polar Duke (seconded to USCG, on charter to
IIT, for USARP) passed of fshore on 31 st: Waghorn went out by bot arranged a plckup when Polar Duke was due to pass by again in a foat and USARP agreed to this and Greenway was put on board. When the ship arrived at Punta Arenas, an RAF Medical orderly met him; he was X-Rayed in the commerciel flights, accompanled by the Medical the rerly soon to Britaln by in Britain, he was operated upon at Queen Elizabeth Hospital. The whole evacuation had been remarkably quick, taking only 15 days from the injury

Waghorno After Waghorn had broken his leg on 4th March, a major rescue filight and the BAS Twin Otter from Rothera. The Chileans and USARP also offered to help. The rescue itself is described in the narrative. Endurance was due to pass the island at about that date during her 3rd Work unscheduled movements. From the Falklands Waghorn was flown back to Britain, where he was operated on at the RN Hospital Haslar, 16 days after
the injury.

ships when due to pass Brabant Is and had been undertaken with negl igible deviation ind injurles are rather more likely to occur during an adventurous expedition like this, but accidents are possible even in the comparatively safe conditions of an Antarctic research base as well as. on 2 man BAS field trips. The level of
professional medical expertise avallable throughout the expedition was higher than that normally available in either BAS or USARP bases, and the overall medical risks of the

Wositive would like to thank all those concerned, for their good humoured, helpful and 


\begin{tabular}{|c|c|c|c|}
\hline & FINANCE & EQUIPMENT & OTHER \\
\hline \multirow{10}{*}{ 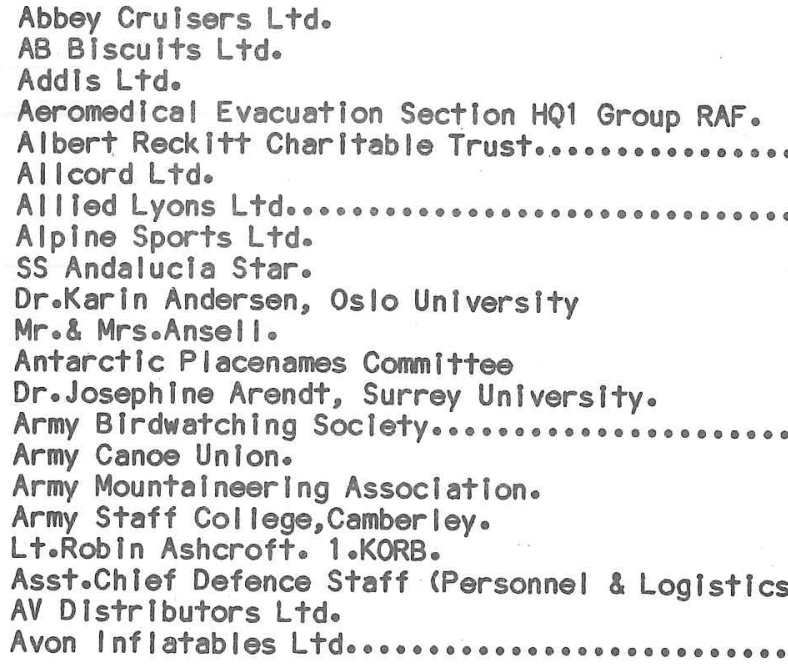 } & & & Preparations \\
\hline & $\begin{array}{l}\text { free } \\
\text { free }\end{array}$ & $\begin{array}{l}\text { Biscults } \\
\text { Toothbrushes }\end{array}$ & \\
\hline & o.Sponsor & & Flights \\
\hline & & I ceaxes & \\
\hline & & Climbing geal & \\
\hline & Sponsor & & \\
\hline & & & $\begin{array}{l}\text { Forbearance } \\
\text { Science }\end{array}$ \\
\hline & $\begin{array}{l}\text { Sponsor } \\
\text { Sponsor } \\
\text { Sponsor }\end{array}$ & & \\
\hline & & & $\begin{array}{l}\text { Preparations } \\
\text { Support }\end{array}$ \\
\hline & & $\begin{array}{l}\text { Clne e } \\
\text { Booats }\end{array}$ & \\
\hline
\end{tabular}

Be Baggins $L+d$.

aiscount............

Ba Barbour Ltdo

Basement Studios Ltd

loan

Jackets
Mariner Outboard Motors

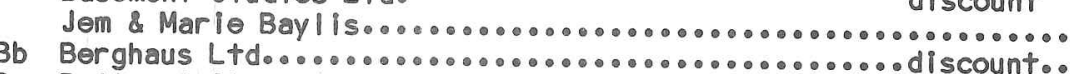

Stickers
Rucksacks..... Falk lands help
Snowgaiters etc

Bc Bolle et Cle.

Snowgoggles
Boat gear
Plastle barris

Bf Bowater International of Stockport.

Braemar FlIms Ltd.

freo Plastic barrels

Tony Bray (Bradford Stamp Centro)......
Bridport Gundry Ltd.

Postcards

Britannia Royal Naval Coll lege, Dartmouth.

ishing nets

British American Tobacco Co.Ltdo...0...0.............. freo.........Cigarettes

British Broadcasting Corporation.

British Canoe Union.

British Museum of Natural History.

Sponsor

-1
0 parent unit

EI

EI

[늘

트

E 3

E 3

늘

$\therefore 3$

$=7$

5

$=-3$

$-3$

Bd $\mathrm{Br}$

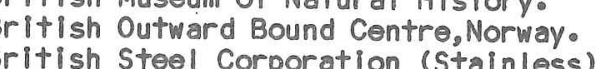

British Trust for Ornithology.

Sponsor

All round help

Amanda Broughton, Miss Brabant Island.
Dr.D.H.Brown, Bristol University.

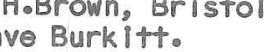

Cdr \& Mrsomalcolm Bur ley.
Mr.\& Mrs.l MoBurl Inghame

Cable \& Wireless Lido

Camera Care Systems Ltdo
Canoe Contre, Crediton.

Carl Zeiss (Obberkocheni) Ltd.

g Canadian Commercial Organisation.

E.A.Carey (Europe) Ltdo.....

Casella Lonson Ltd.

Catterick Garrison.

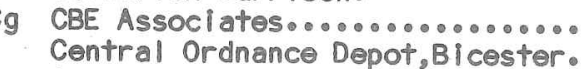

Contral ordnance Dopot, Bicestior.

Cb Mro \& Mrs.Bill Chardo

Cc Clan Designs L

Shirts Sclence
Training

Sledges
Weighing scales

Science
Recce

Sponsor
Sponsor

Recce photos
All round support

$=3$

$=3$

$E \exists$ 
Colour Processing Laborator ies Ltd................. free....... . Displ ays.... Processing
Profiessor Wop.Col lahoun, Medical Research Council.

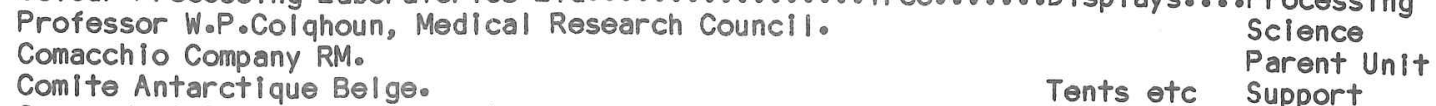

Comite Antarctique Belge.

Commandant General Royal Marines.

Tents etc Commander British Forces Falkland Islands. Commando Training Centre RM. Commando Logistic Regiment RM.
Corah Ltd, Leicester Cotswold Camping L+d.

Major David Counsell RA.

toDavid Coward IstoLight Infant

Dr.Alan Cowan.

Sub.Lt.Matthew Cox RN.
Professor RoMoM.Crawford, St.Andrews University.

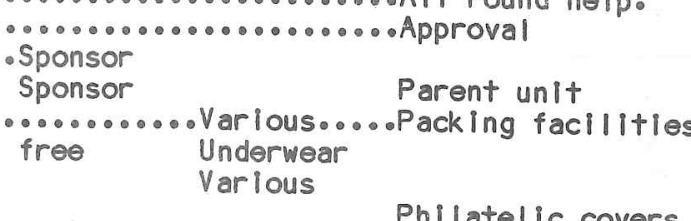

Sponsor

Underwear
arious

Philatelic covers

Proparations Sclence Science

Surgeon Captain David Dalgl lesh RN. Dr.Herbert Dartnall.

Dr.J.Davenport, UCNh.

Do Davio Mason \& Co.Ltd

Sclence
Advice

Defence Secretarlat 5 .

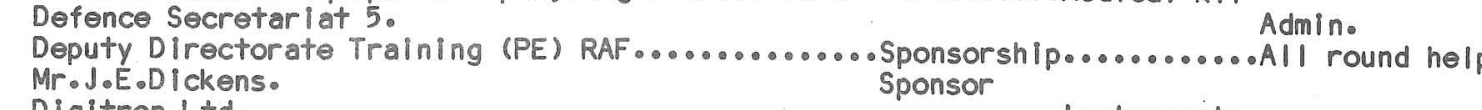

Sponsor Instruments

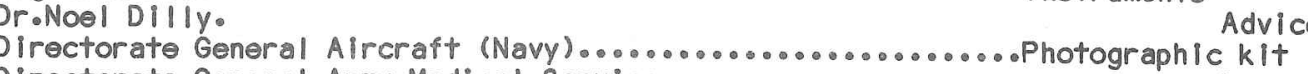

Directorate General Army Medical Services.

Doctors

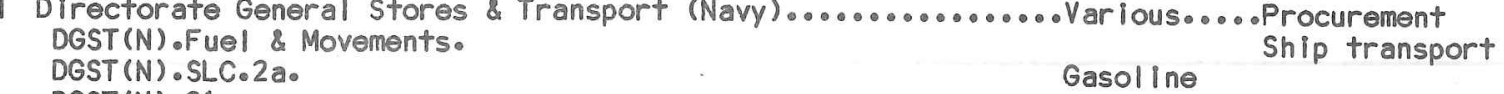

. Advice

DGST (N). 210
DGST (N). 31 .

soline ship traneort

De DGST $(N) .82 .0$

Director of infantry.

Directorate Movements (Army)

Boats
Clothing
Clothing

Dg Directorate Naval Education Services.

Directorate Naval Officer Appointments.

Directorate of Overseas Surveys.

Directorate of Public Relatlons(Navy).

RRS Discovery, StoKatherines Dock.

Douglas Gill Ltd

Dh Duracell

\begin{abstract}
(n)
\end{abstract}
Edinburgh Trust....................................... Sponsor
Roger \& Norma Edwards.

Ele international Ltdo

DroHayden Ellis, Aberdeen University.

Eb Georges Emery et Cie.

Emtrad Ltd o.

d Engineer in Chief of

Captain Everett RNo
Expedition Advisory Centre (RGS)

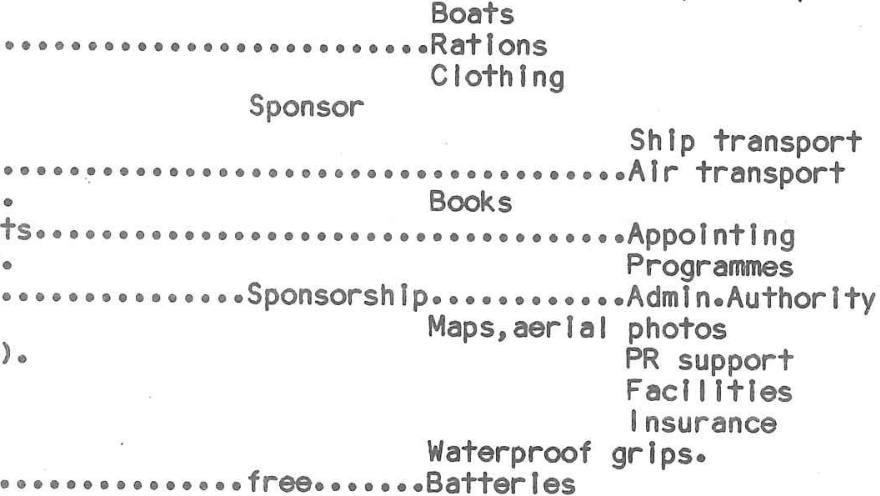

Batterles

Falklands help

Science
Mountaineering kit

oan.......... Rk i bindio distress beacons

.discount....Skis \& bindings

Advice
119

Falkland $\mid$ slands Company.

Falk Mrs.Betty Feltham.

MissoLaurie Foltham

Fa Fleld \& Trok Ltdo.

Fisons Pharmaceuticals.

MroNell Fitch, SteAndrews University
FJall raven Sports Equipment UK Ltdo

Flag Officer Medway.........

Flag offlcer Scotland \&

Fleet Amenities Fundo...................

Fleet Photographic
Fletcher \& Cooltdo

$\mathrm{Fe}$ Fotcher \& Mrs J Filint.

Foredek International Ltd........ Mrelgn \& Commonwealth Offi
MroRobert Foxo Freder ick AoCook Society.
Sir Vivian Fuchs........... FuJ imex Ltdo.... Fujl Photo Film Ltd Rear Admiral \& Mrso JPH Furse. Mrss a aye Furse
Furse House.

Baron Gaston de Gerlache de Gomery...
Gilberts of Catford Ltdo

Gitzo et Cle.

Professor Rainer Goldsmith, Chelsea College.

a Gro John Gordon-

Goredale Ltdo
Surgeon Commander (D) Ted Grant RN.

Surgeon Commander (D) Ted Grant
Grant Intruments (Cambi idge) Ltd.
Dr.C.P.G.Green, London Uni vers ity.

Dr.C.P.Green, London
Griffin \& George Ltd.

Mr.\& MrsoNick Hadden
Halba Shiping Coo

Ha Mrs

Dr. Jim Hansom, Sheffleld University ...

Murgeon Vice Addyiral sir John
Sur. Amof

. ................................

Hawker Siddeley RAE 50thi

Spons

Sponsor
fren...... Cyalume Iightsticks
fon

discounto o o Fii

...All round support

Hb Hakl

Hawk ins \& Manwaring L+t...
HJ Heinz Co Ltdo

ho Hellma (England) Ltdo

Mr.Wally Herbert.
HMS Bar Protector.

HMS Bar Protector.
HMS Caledonia.

HMS Caledonia.
HMS Centuriono

HMS Cochrane Wardroom

HMS Dryad.
HMS.

He

MMS Endurance.
HMS Nelson.

HMS Osprey.
HMS Pembroke.

.Secretary etc.
Facilities

.Various...... Support

Honda spares
Monopod

free

amous Grouse whisky

lce corer
Clothing

Instruments Advice

Science

skidoo sparolklands help

Support

discount Tent

Anniversary Awards.......... Sponsor

Waterproof notebooks

Photographic fllters

Thermal clothing

Sponsor

Sponsor

Sponsor
Sponsor

Drafting
Parent unit

E 3

E 3

EI

53

5

$-3$

-3
-3

$E \equiv$ 
120

His Royal Highness The Prince of Wales.

Hogg Robinson Ltdo

Dr.Peter Hooper

Howson F.Devitt \& Sons Ltd.

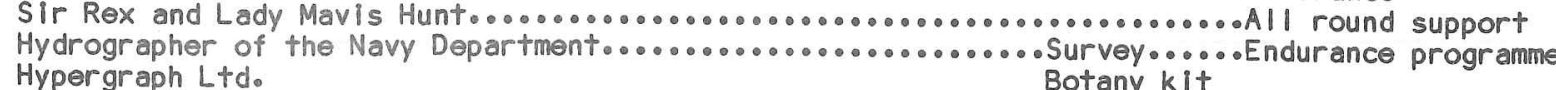

la George I bberson L+do

discount Knives

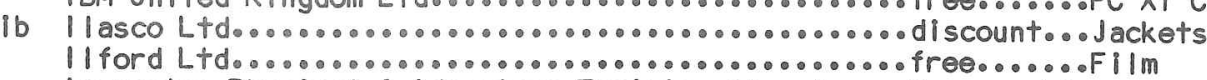

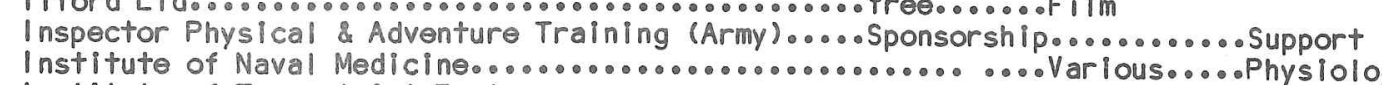
institute of Terrestrial Ecology.

trem Inverness Training Camp.
Rear Admiral sir Edmund Irving

Island Computer Systems Ltdo

Facilitios

Support IBM Computer service

Ja Jademoon $L+d$.
Jb Njavelin $L+d$.

Jeppesen Heaton Ltd

Johnson \& Johnson Ltd.

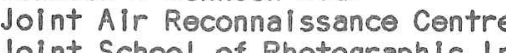

Joint Services Expedifion South Georgla 81/82.

Jolnt Services Expedition Trust......................

Joint Services Mountain Training Centre (Scotiand).

Jc Woint Services
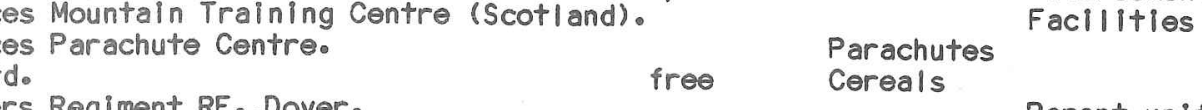

Ka Karrimor Weathertite Products Ltd.

Parachutes

discount Tents

Freighting
History
discount Waterproof cameras

Aerlal photos

Training

Various. Training

Endorsement
Facillities

Kemp Bros \& Wootton Ltd.

Kennett Engineering Lt

MV Kerens.
Kiel Training Centre.

Kc Kodak UK Ltdo

La Lakeland Plastics Ltd. LD Mountain Centre.

c Leroca Lto

contre.

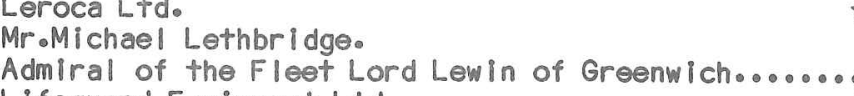
Lifeguard Equipment
Light Alloys Ltdo

Le Will I lam Little \& Sons Ltdo
Lofthouses of Fleetwood Ltd.

Lofthouses of Fleetwood Ltd

d.................. freo........Rucksacks etc Printing free Coifee
free....... Benbo tripod

$\begin{array}{ll}\text { Sponsor } & \text { Passage } \\ & \text { Parent unit }\end{array}$

Film
Bootstretcher

Watertight barrels

Var lous

Trithall hut design Tri-wall hut design (i)

Metal containers Bootees -Var lous

\section{Lt.Cdr.Tom McAndrew RN.}

Mr.D.F.M.MeGregor, London University

Malvernian Society..............

Map Room, Min istry of Defence
Marne Biology Laboratory. PIymouth.

Maritime Trust

Marks \&. Spencers $L+d$.
Dr.NoR.Maslen, T.D.R.।.

Mason Firearms Ltd.

Mr. Jose MoMayorga...........

Medical Directorate General (Navy.

Meteorological Office.

MEC Survival L+do......

MroEdwin Mick leburgh.

Military Vehicles \& Engl
Mc Corporal NoMofer RE.

Morris, Nicholson \& Cartwright

Me Mountain Equipment Ltdo

Mf Muk luks L+do.

Multifabs Ltd ...............................

Na Nabisco Ltdo
National Maritime Museum.

National Maritime Museum.
Natural Environmental Research Councti

Ne Nestle

Nestlo Co.LTdo

Nevisport $L+d$.
Nikon UK $L+d$.

Ne $N$ int

Norsk Pol arinstitutt.

Northern White Wator Centro

Nuffield Trust for the Forces
Nursery Supplies (Bourne) Itd

Oates Memorial Museumo

AB Optimus Ltd
Mrotholifver.

.................................. Stoves Sponsor

Outboard Marine (UK) Ltdo.........

Outdoor Pursuits
Dr.0xley, UCNW.

Pacesetter Enterprises Ltd.

Panalpina International Transport L $L+d$

Paradigm (UK) L L to
Midshipman K.Park RN.

Midshipman K.Park RN.
Pelling \& Cross Ltdo...

Pa Perard (Yorkshire) Ltd.

Perard (Yorkshire) Ltdd
Personnel Management Centre (RAF)

Peter Storm Ltd.

Petroleum Centre RAOC.....
Philatel Ic Bureau, Stanley.

Phoenix Mountaineering
PIIkington PE Ltdo

Plancraft Watersports.

Plessey Electronic Systems
MV Polar Duke ( I cebreker) Polarold UK L+d.

Polar Postal History Soc
Polysox Ltd.
g Polywarm Products Ltd.
Commander J.E.Porter RN.

Commander J.E.Porter RN. Geraldine Prentice.

Yorkshire 20.0 .0 .0 Sponsor

h Principal Supply \& Transport Off fcer (Navy) Devonport.o...... Principal Supply \& Transport Offlcer (Navy) Portsmouth. Procter \& Gamble Ltdo
Professional Dental Care Services Ltdo

Prontaprint (Various branches).

Professor. Geoffrey Pugh, Portsmouth Polytechnic...................
Mr.\& Mrs.Paul Purk isso

Sponsor

froe Lifojackets Sclence Maps

Science
Facilities

science

gun sclonce Golf ii LoRangefinder Meteequipment Support Tents Advice
Skidoo preps.

iscount Varlous

ree Barbour jackets

reo Boots

Drysuits

free Cereals

Rescue flights

Assistance

discount Thocolate etc.

Cameras etc.

Waterproofing agents
Support

Canoe clothing.

discount Bamboo marker poles

35HP OBMs

climbing ropes
Science

Cinefilm production port agency

free conputer software agency

hoto kit.Photo.support

iscount Cameras etc

.

discount Underwear

.

Canoe accessories

............ Passage

di scount

Sponsor

Stockings

${ }^{2}$ 
122

Queen Ellizabeth Military Hospital, Woolwich.

Racal Telectronics Ltd

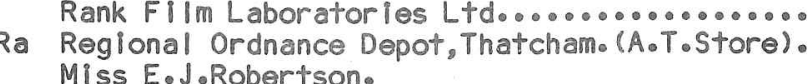

Rodol fo Marsh Base (Chile).

Rb Rohan (UK) L

Rolex Enterprise
Rolex (UK) Ltdo

Rothera Base................

Rc Rowntree

RAF Bensono
RAF Brize Norton, \& VC 10 Squadrons.

RAF Cottesmore.
RAF College Cranwell.

RAF Germany,
RAF Gutersloh.

Rd RAF Kin loss . . .
RAF Luchars.

RAF Leuchars Officers Mess.

RAF Lyneham, \& Hercules Squadrons.

RAF News.
RAF Odiham.

RAF Odihamo
RAF Ornithological Society.
RAF Outdoor Activities Centre, Ll anrwst.

RAF Strike Command
RAF Support Cormand.

Royal Angl lan Regiment...........

RAMC HQ Mess Fund
Royal Botanic Gardens Edinburgh

Royal Botanic Gardens Edinburgh.

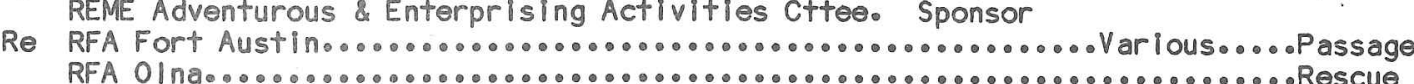

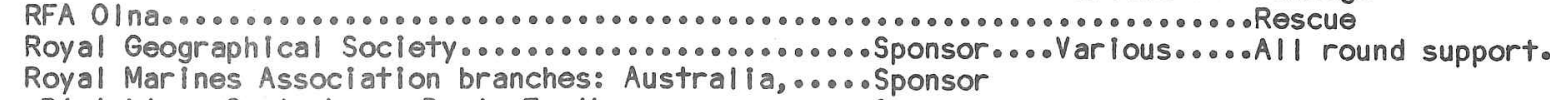
Bletchley, Canterbury, Deal, Eastbourne, Sponsors Mamorgan, Gosport, kidderminster, Devon, Stoke (\& Newcastle) -on-Tren

RM Barracks, Stonehouse

\section{RM Poole.}

RM Poole Corporals Club. RM Poole Sergeants Mess. RM Stonehouse Royal Military College of Sclence, Shrivenham
Royal Naval Engineering College, Plymouth.

RN Hospital, Haslar.

Sponsor

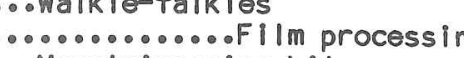

Salling Association, Medway Branch.

RN Stores Depot, Llangennech.

Rh RN Victuali ing Dopo
RRS Bransfield.

Royal Scottish Geographical Society

Royal scottish Museum.
Russells of Newport.
Sponsor free free

Sponsor

Sponsor
Sponsor

ponsor

Sponsor

Sponsor

Sponsor

Sponsor Breeches
Skidoos

Rolex Oyster watch

Sweets help

Preparations Parent unit

Parachutes ent unit Parent unit

Air travel

Publicity
Preparations

Facilities

Support

Parent unit

Sponsors
Sponsors

\begin{tabular}{|c|c|c|}
\hline & & Return stores. \\
\hline $\begin{array}{l}\text { Sponsor } \\
\text { Sponsor } \\
\text { Sponsor } \\
\text { Sponsor }\end{array}$ & Boat kit & $\begin{array}{l}\text { Printing } \\
\text { Parent unit }\end{array}$ \\
\hline onsor & & Return stores \\
\hline & Wind-gener & ator \\
\hline $\begin{array}{l}\text { oan....... } \\
\text { ponsor. } \\
\text { soonsor }\end{array}$ & $\begin{array}{l}\text { Canoess } \\
\text { Climbing } 9\end{array}$ & \\
\hline & $\begin{array}{l}\text { Various } \\
\text { Varlous } \\
\text { Rations. }\end{array}$ & $\begin{array}{l}\text {-Packing } \\
\text { Cache muste }\end{array}$ \\
\hline bonsor & & \\
\hline count & $\begin{array}{l}\text { Collectin } \\
\text { Sound rec }\end{array}$ & $\begin{array}{l}\text { ju ipment } \\
\text { ng equi ipment }\end{array}$ \\
\hline
\end{tabular}

Mountaineering kit

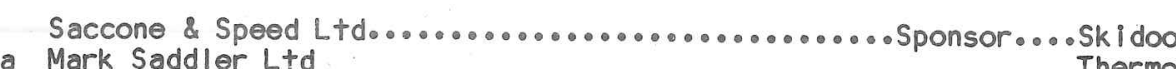

Thermotex walstcoats St. Bartholomews Hospital ............................... Sponsor. discount Skis \& bindings School of Military Survey, Hermitage.
School of Elect. \& Mech。 Engineering, Bordon..................... Sledges......Stores packing
Mrsaing Mrs.M.G.Scott-Easton. Scoott Polar Research Institute. Services Bolk In cer Falkland Islands............ Services Sound \& Vision Corporation. Mrokelth Shack leton.
Shaftesbury Marketing Ltdo

Sc Shell Chile L+do Mr.ollver Shepard. Astar Gasolino

Fish Laboratories, Pitlochrie DroHumphrey Smith, Coventry(Lanchester)Polytechnic discount Pleps etc. Science

Se Snow \& Rock Ltdo
Society Expeditions.

Society Erodessional civil Englnars (Mirolado Sport AS.....

Solent Audio-Visual Ltd.

$\begin{array}{ll}\text { Sg } & \text { JowoSpears \& Sons } L+t d . \\ \text { Sh } & \text { Speclal Air Service }\end{array}$ John Spencer Associates.

Splashsport $L+d$ do Stanfords (Maps) Steep leprint Ltdo

Si Stores \& Clothing R \&

Strand I Insurance Brokers.

Mr.\& Mrs.Donald Strang.....

DroDavid Sugden, Aberdeen University.

Survival Aids L+d.

Swix Sport AS.

Synd Spated features Ltd.

Ta Taylors Eye Witness Ltdo

Teachers Whisky Ltdo

noaks, (G.\& D.MiIIs)

Captain Allan Thompson RM.

Tb Tirfor Ltdo 24 Mileta Sports $L+d$.

Tc Topham Picture Library. Edentridge.

Th Touring Sports Ltdo (latest name) Transantarctic Assoclat lo Transworld International L+do

Trenchard Memorlal Awards Scheme.

Te Troll Safoty Equipment Lt+d.

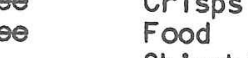

Ski-skins etc

Sponsor
discount... Pulk sledges Publicity

free Games
loan Solar panels Camera servicing

SS Uganda.

Ua Uitimate Equipment Ltdo

Unitad Biscuits Ltd.

US Antarctic Research Programme.

US Coastguard Service.
Dromichael Usher, York University.....

sponsor

Paddle mitts Fundraising

Maps

Labels
Support Sponsor....... Varlous

Wooden hut sclence free Varlous
free Skl waxes

$\begin{array}{ll}\text { free } & \text { Knives } \\ \text { free } & \text { Teachers Whisky }\end{array}$

sonsor

Sponsor Vhoto.llbrary 1986 Slscount... Tents etc

Skidoos, sledges
Rolex film

ponsor

Hut material
Climbing goar

Passage

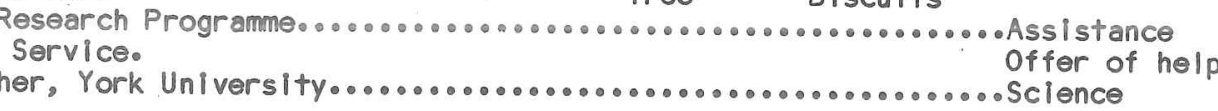




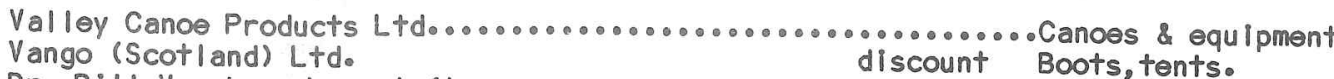
Dro Bill Vaughan, Lowestoft. Waddingtons Games $L+d$.
J.Wal ter Thompson $L+d$. Dan........Anemometor Warner Lambert Ltdo

Gino Watk ins Memorial Fund free Medical supplies WIId Country Lt+d Mr.\& Mrs.Ken Wilson.

Wintergear

free Shovels, knives Chief Petty Officer Steve Williams RN.

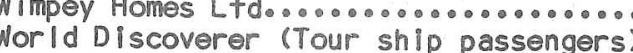
Wrigleys Ltdo
pr. Clive Wyborn, Central London Polytechnic Teachers whisky
Tents $\theta+c$

Yachtspeed Industrial Servi
Yacro Ltdo ......... Banking; loan Assistance

Sponsor Canoe

free Chewing gun

free Meience .Shovels
Skidoo strops

ist Battalion Queens Lancashire Regiment.

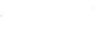
I Kings Own Border Regimeat 3 Flight Army Air Corps.

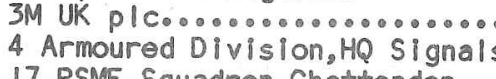
17 RSME Squadron Chattenden

3a 36 Engineer Regiment。

74. Commando Group

24. Locating Regiment RA.

.............

free........ Film

Sponsor

..Winches...

Sponsor
Accommodation Chi

Parent unit
Preparations Parent unit

Parent unit Parent Unit Rescue

\section{Thls report was written by May 1905 , but printing took 10 mon}

and corrections below cover errors and omlssions in the report as it stands; no attempt has
been made to cover progress since the expedition

- NEW OFFICIAL PLACENAMES.

The following six names have been approved by the Antarctlc
ficlal names used in this report should not by Lanusse Bay. (Instead of "Prince Will I lam Bay").

Larvlk Harbour. (Instead of "Patria Bay").

Cook Summit. (instead of "Mount Frederick Cook" guano Bay, not named by the expedition). Kayak Bay. (between Hunt and Lecointe Islands, not named during the expedition).

2. MISPLACED OFFICIAL PLACENAMES. Re-examination of the original DOS manuscript map has

Mount Ehrlich actually applles to the hill we called "Emery Peak".
aill we called "Noddies Hat". The peak pe the to the hill we called "Ben Bangers : Mash"

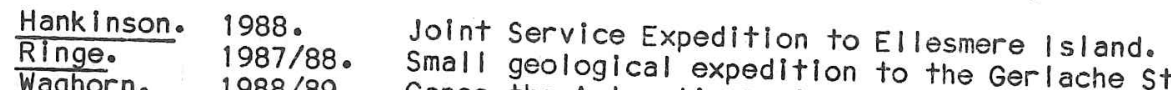

4 MANUSCRIPT AMENDMENTS.

History, page 9, 4th para. Penola did pass Brabant Island, so delete "probably"

Lower photograph opposite p57. Delete de Gerlache and substitute Evans.

Geology, p60, 7th para, last line. Delete $950 \mathrm{~m}$ and substitute $950 \mathrm{ft}$.

Meteorology, p64. In column under "Days when Winds over 34 knots recorded" delete
delete
$\frac{188 \%}{48 \%}$ of days and substitute $31 \%$

Medical, p77. Under Second Summer add "WIIlliams also fractured a bone in his hand Tents, p96. At foot of page add the following comment:
"Comparison with the Belgian In $1957 / 58$ demonstrates the Antarctic Expedition led by Gaston de Gerlache They used a basehut: 440 tons of stores were needed for
We used tents:

FInance, pllo. Under Income amend NERC Research Grant to \& 2,300. $\begin{array}{ll}\text { Equi pment Sales } & \text { to } \approx \frac{2,300}{1,200} \\ \text { and Total income } & \text { to } \hat{\alpha} 95,800\end{array}$

Under Expenditure amend Stlll Photography to $\frac{8}{8,400}$. Printince

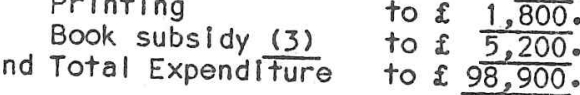

Add "Note (3). Book Royalties will be pald to the Expedition."

Acknow ledgements. P117. Add: "British Army of the Rhine - Sponsor"。

p120. Add: "Kenbe Binders
p122. Add: - "Report binding"

$$
\text { Mritur }
$$

18th April 1986 